\title{
지방공항을 활용한 지역관광 활성화 방안
}

이원희

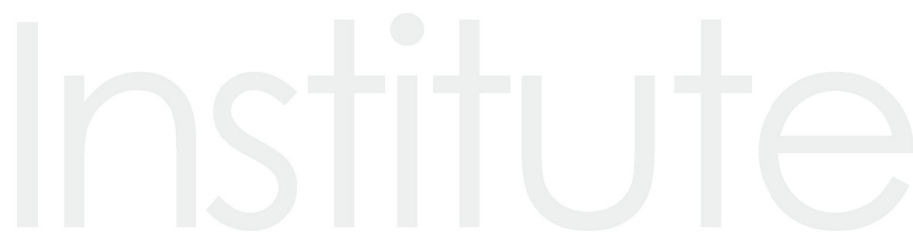





\section{지방공항을 활용한 지역관광 활성화 방안}

A Research on Inbound Tourism Activation Using Regional Airports

이원희 

연구책임

이원희 한국문화관광연구원 연구위원

공동연구

박진서 한국교통연구원 연구위원 

지방공항을 활용한 지역관광 활성화 방안

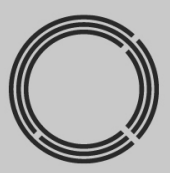

연구개요 



\section{1. 서론}

\section{1. 연구 배경 및 목적}

- 방한 외국인 관광객 수는 최근 10 년간 두 배 이상 증가하였으나, 외국인 관광 객의 방문 지역은 여전히 서울 수도권 등 일부 지역에 편중되고 있음

- 방한 외국인 관광객들의 서울 수도권 집중 현상이 고착화되면서, 국내 지방공 항의 입국 관문 역할과 거점 기능 강화를 위한 정핵이 요구되고 있음

- 지방공항은 방한 외국인 관광객의 지역 방문을 촉진하는 중요한 관문으로서, 관광 및 항공 분야 간의 협력체계 강화와 연계정책 수립이 요청됨

- 본 연구의 목적은 지방공항의 관문 역할을 강화함으로써 방한 외래관광객 유 치를 도모하고 지역관광을 활성화하기 위한 정책 방안을 제시하는데 있음

- 보다 구체적으로 본 연구의 세부 목적은 다음과 같음

- 첫째, 방한 외래관광객들의 지방공항 이용 및 지역관광 실태를 진단하고, 주요 문제점과 개선사항을 도출하고자 함

- 둘째, 지방공항의 국제노선 운항 현황을 분석하고, 방한 외래관광객 유치 관점에서 한계와 개선사항을 검토하고자 함

- 셋째, 외국사례를 조사하고, 지방공항을 활용한 외래관광객 지역 유치를 위 한 정책 방향과 추진과제를 제시하고자 함

\section{2. 연구 범위 및 방법}

- 연구 목적을 고려할 때 방한 외래관광객 유치 측면에서 정부의 관광거점도시 정책과 연계 가능한 지방공항을 중심으로 살펴볼 필요가 있음

- 따라서 본 연구에서는 '대도시형 지방공항'의 대표 사례인 김해공항과 '지역연 계형 지방공항 의 하나인 무안공항을 주요 대상으로 선정하였음

- 문헌 조사를 통해 문체부와 국토부의 관련 정책 동향을 검토하였으며, 지방공 항의 현황 분석을 위해 출입국 관광통계 및 항공통계를 분석하였음 
- 김해공항과 무안공항을 직접 방문하여 관광편의시설 및 서비스 현황을 점검하 고, 한국공항공사 관계자를 대상으로 면담 조사를 실시하였음

- 본 연구의 진행 과정에서 한국교통연구원, 한국공항공사, 한국항공협회, 지역 관광공사, 관련 대학 등 다양한 전문가들의 의견을 수렴하였음

- 방한 외래관광객의 항공편 이동, 공항 접근교통, 향후 개선사항을 도출하기 위하여 「2019 항공여객 OD 및 특성조사」 데이터를 재분석하였음

- 코로나19 영향으로 설문조사 실시가 불가능하여, 그 대안으로 지방공항 이용 경험이 있는 외국인 대상 개별 심층 인터뷰 조사를 실시하였음

\section{2. 지방공항 현황 및 이용 분석}

\section{1. 방한 외래관광객 현황}

\section{가. 지방공항의 입국 관문 역할과 기능 미흡}

- 전체 방한 외래관광객의 약 $90 \%$ 가 공항을 통해 입국하고 있으며, 여러 교통수 단 가운데 항공이 차지하는 비율은 최근 증가 추세를 보이고 있음

- 국제관광에 있어서 항공교통의 중요성이 커지고 있으나, 인천공항 허브화 전 략은 외래관광객들의 서울 수도권 방문 집중을 심화시킬 우려가 있음

- 실제로 방한 외래관광객들이 인천공항을 통해 입국한 비율이 약 $70 \%$ 에 이르 고 있으며, 김해공항과 제주공항 등 일부 공항을 제외한 국내 지방공항은 입 국 관문으로서 역할과 기능이 미미한 실정임

\section{나. 주요 방한시장별 지방공항 이용 패턴 차이}

- 중국시장은 제주공항을 통해 입국한 비율이 다른 국가들에 비해 상대적으로 높고, 일본시장은 김포공항과 김해공항을 자주 이용하는 것으로 나타났음

- 장거리 시장인 미국과 동남아의 홍콩, 베트남, 태국은 방한 입국 시 인천공항 을 이용한 비율이 높게 나타나 지방공항의 적극적인 유치 노력이 요청됨 
- 한편 중국과 동남아 시장의 경우 무비자 제도 시행 여부가 방한 관광수요 창 출 및 국내 지방공항 이용에 영향을 미친 것으로 추측됨

\section{2. 지방공항 국제노선 현황}

\section{가. 국제여객노선 운항실적 인천공항에 집중}

- 항공통계에 따르면, 국제여객노선 운항실적은 인천공항이 약 $74 \%$ 로 압도적으 로 높고 김해공항, 김포공항, 대구공항, 제주공항 등의 순임

- 여객실적도 인천공항에 이어 김해공항, 김포공항, 제주공항, 대구공항 등의 순 이며 환승(통과)여객 대다수가 인천공항에 집중되고 있음

\section{나. 아웃바운드 수요 중심의 국제노선 운항}

- 연구의 주요 대상인 김해공항과 무안공항의 국제여객노선 운항 현황을 살펴보 면, 기존에는 우리 국민의 해외여행 수요와 선호 목적지를 중심으로 직항노선 과 운항 편수가 배분되어 온 경향이 많은 것으로 분석됨

- 김해공항과 무안공항의 국제노선 항공사별 통계를 분석한 결과 국내 저비용항 공사(LCC)의 비중이 각각 $49.4 \%, 76.9 \%$ 로 높게 나타났음

\section{3. 연구대상 지방공항 현황}

\section{가. 지방공항 안내 및 연계교통 개선 필요}

- 김해공항과 무안공항은 기본적인 관광편의시설과 서비스를 갖추고 있으나 외 국어 통역 지원 및 관광안내정보 서비스 등의 개선이 요구됨

- 공항에서 배후도심이나 주요 관광지까지 연결하는 대중교통 서비스가 부족한 경우가 많아 공항을 이용하는 외국인 관광객의 불편이 예상됨

- 지방공항의 접근성 개선을 위해서는 KTX, 도시철도 등과 연계를 강화하고, 개별여행객을 위한 렌트카, 공유차량 서비스를 확충할 필요가 있음 


\section{3. 조사 데이터 분석}

\section{1. 항공여객 $\mathrm{OD}$ 조사 데이터 분석}

\section{가. 지방공항 이용 외국인 대다수가 개별여행객}

- 「2019 항공여객 OD 및 특성조사」 데이터 분석 결과에 따르면, 김해공항과 무안공항을 이용하는 외국인 관광객 대다수가 '개별여행' 형태였음

- 김해공항 이용 외국인 관광객은 한국을 재방문한 경우가 많았으나, 무안공항 이용 외국인 관광객은 한국을 처음으로 방문한 경우가 많았음

\section{나. 저비용항공사(LCC)와 직항노선 주로 이용}

- 김해공항을 이용하는 외국인 관광객은 'LCC'를 가장 많이 이용하였으며, 무 안공항의 경우도 'LCC'의 이용 비율이 약 $89 \%$ 로 매우 높았음

- 해외 출발지에서 '직항편' 으로 한국에 입국한 경우가 대다수였으며, 국내 입국 시에도 '김해공항'을 이용한 비율이 약 $89 \%$ 로 나타났음

- 무안공항을 이용하는 외국인 관광객의 경우 국내 입국 시에도 '무안공항'을 이용한 비율이 약 $86 \%$ 로 나타났음

\section{다. 환승공항 선택기준은 항공요금과 항공스케줄}

- 김해공항을 이용하는 외국인 관광객들의 최종 목적지 국가는 '일본', '대만', ‘중국' 등이었으며, 무안공항을 이용하는 외국인 관광객들의 최종 목적지 국 가는 '대만', '일본', '태국' 등의 순으로 나타났음

- 한국 외 다른 국가를 방문하는 환승객의 경우, 항공요금이 저렴하고 항공스케 줄이 적합했기 때문에 환승공항으로 선택했다는 응답이 많았음 


\section{라. 배후도시 및 주변지역 연계교통 개선 필요}

- 김해공항을 이용하는 외국인 관광객들은 '부산'을 가장 많이 방문하였으며, 방 문지까지 이동 시 택시나 지하철을 주로 이용하였음

- 김해공항으로 이동 시 ‘택시’나 ‘지하철', ‘경전철' 등을 많이 이용하였으며, 공항까지 평균 소요 시간은 약 42 분으로 나타났음

- 무안공항을 이용하는 외국인 관광객들은 '전남'지역과 '광주'를 가장 많이 방 문하였으며, '부산'도 일부 방문한 것으로 나타났음

- 무안공항으로 이동 시 ‘택시'나 ‘승용차', '시외/고속버스' 등을 많이 이용하였 으며, 평균 소요 시간이 약 84 분으로 오래 걸리는 것으로 나타났음

\section{2. 외국인 개별 심층 면접 조사}

\section{가. 언어소통 문제와 외국어 안내정보 부족}

- 외국인 인터뷰 조사 결과에 따르면, 국내 지방공항을 이용할 때 외국인 관광객 들이 느끼는 가장 큰 불편은 언어소통 문제인 것으로 나타났음

- 또한 이들은 국내 지방 여행을 위해 대중교통 및 주요 관광지, 이벤트, 식당 등에 관한 안내 정보를 가장 필요로 하는 것으로 조사되었음

\section{나. 지방공항 연계 대중교통(버스) 개선 시급}

- 교통수단 중에 버스가 승차 위치, 운행 방향, 정류장 명칭, 운행 노선, 배차 시간표 등에 관한 외국어 안내 정보가 없어 많이 불편한 것으로 파악되었음

- 지방공항은 인천공항에 비해 규모가 협소하지만 식당과 카페, 라운지, 대기시 설, 면세점, 24 시간 운영 환전소, 약국, 와이파이 렌탈, 수화물 보관소 등 편의 시설 및 서비스에 대한 기대를 갖고 있는 것으로 나타났음 


\section{4. 외국 유사 사례 분석}

\section{1. 일본 사례 조사}

\section{가. 공항 세일즈 정책 및 $\mathrm{LCC}$ 와 외항사 유치}

- 일본은 ‘방일여행객 유치 지원공항' 인정제도를 시행 중이며, 지방공항의 국제 노선 신규취항 및 증편을 위한 공항 세일즈 정책을 추진하고 있음

- 일본의 간사이공항은 외국 국적 항공사가 전체 운항편수의 약 $87.5 \%$ 를 차지 하고 있어 우리나라 김해공항과는 큰 대조를 보이고 있음

- 간사이공항에서 운항 중인 전체 항공사 중에 LCC는 약 $40.7 \%$ 로 파악되며 중 국, 한국을 제외한 아시아의 경우 홍콩과 대만노선이 활발히 운항중임

\section{나. 개별여행객을 위한 공항 렌터카 편의 개선}

- 사가공항의 경우 국제선 체크인 카운터에 통역 인력을 배치하였으며, 공항 연 계 교통 개선을 위해 리무진 택시 도입, 렌트카 할인 캠페인 등을 시행하였음

- 요나고 공항의 경우 인근 지자체와 협력하여 초청 팸투어를 실시하고, 개별여 행객 시장 특성을 고려하여 렌트카 이용 시 편의를 크게 개선하였음

\section{2. 태국 사례 조사}

\section{가. 공항 도심 접근성 및 셔틀버스 운행 서비스}

- 태국 북부 지역에 위치한 치앙마이 공항과 치앙라이 공항은 도심에서 매우 가 까운 입지 조건을 갖추고 있음

- 치앙마이 공항에서는 공유차량 업체인 'Grab'과 함께 3륜 전기오토바이를 도 입하여 친환경 교통서비스를 제공하고 있음

- 태국의 남부 해안에 위치한 푸켓공항과 핫야이공항은 상대적으로 도심까지 거 리가 멀어 공항셔틀버스를 운행하고 있음 


\section{나. 관광객 편의 서비스 및 항공사 공동 마케팅}

- 태국의 경우 관광수용태세 개선을 위해 중국인 전용 입국 심사대를 개설하는 한편, VAT 현금 환급 서비스를 지방공항으로 확대 실시하고 있음

- 태국공항공사는 8개 언어 서비스 기반 '디지털 에어포츠' 앱을 개발하여 공항 내 출입국 심사 대기시간, 공항 주차장 현황 등에 관한 실시간 정보를 제공하 고, 택시 및 수화물 배달 예약 기능도 제공하고 있음

- 태국은 지방의 새로운 목적지 홍보를 위해 항공업계와 공동으로 대규모 팸투 어를 개최하였으며, 여성관광객 유치 캠페인의 일환으로 공항 내 여성 전용 입국 심사대와 특별 주차구역을 운영한 바 있음

\section{3. 호주 사례 조사}

\section{가. 지방공항의 국제노선 유치 및 해외 마케팅}

- 호주의 경우 시드니공항, 멜버른공항, 브리즈번공항, 퍼스공항 등 4 개의 주요 공항에 연간 항공기 운항이 집중되고 있음

- 주정부는 외항사와 MOU를 체결하여 신규 직항노선 취항을 독려하고, 지방공 항은 지역관광공사와 공동으로 해외 마케팅을 추진하고 있음

\section{나. 공항의 도시정체성 반영 및 혁신기술 도입}

- 호주의 지방공항은 모던한 인테리어와 예술작품, 특산품 전시 등을 통해 지역 의 고유한 정체성을 강조하고 있으며, 공항 주변에는 여행객을 위한 호텔과 숙박시설 등이 위치하고 있음

- 호주 정부는 주요 공항에 생체인식 시스템을 도입해 입국심사 절차를 간소화 하고, 고소득 외국인 관광객 유치를 위한 프리미엄 제도를 마련하였음

- 브리즈번공항은 혁신적인 디지털화폐 결제시스템을 도입하였으며, 멜버른공 항은 LCC 전용 터미널을 운영하고 있음 


\section{5. 향후 정책 추진방안}

\section{1. 목표 및 기본방향}

- 향후 정책의 목표는 국내 지방공항을 활용하여 방한 외국인 관광객의 지방방 문을 촉진하고 지역관광을 활성화하는데 있음

- 이러한 목표를 실현하기 위한 핵심 부문은 1) 지방공항 여객 수요 창출 및 2) 지방공항 이용 편의 개선, 3) 지역 연계 및 관광 활성화로 구분할 수 있음

[그림 1] 정책 목표 및 핵심 추진과제

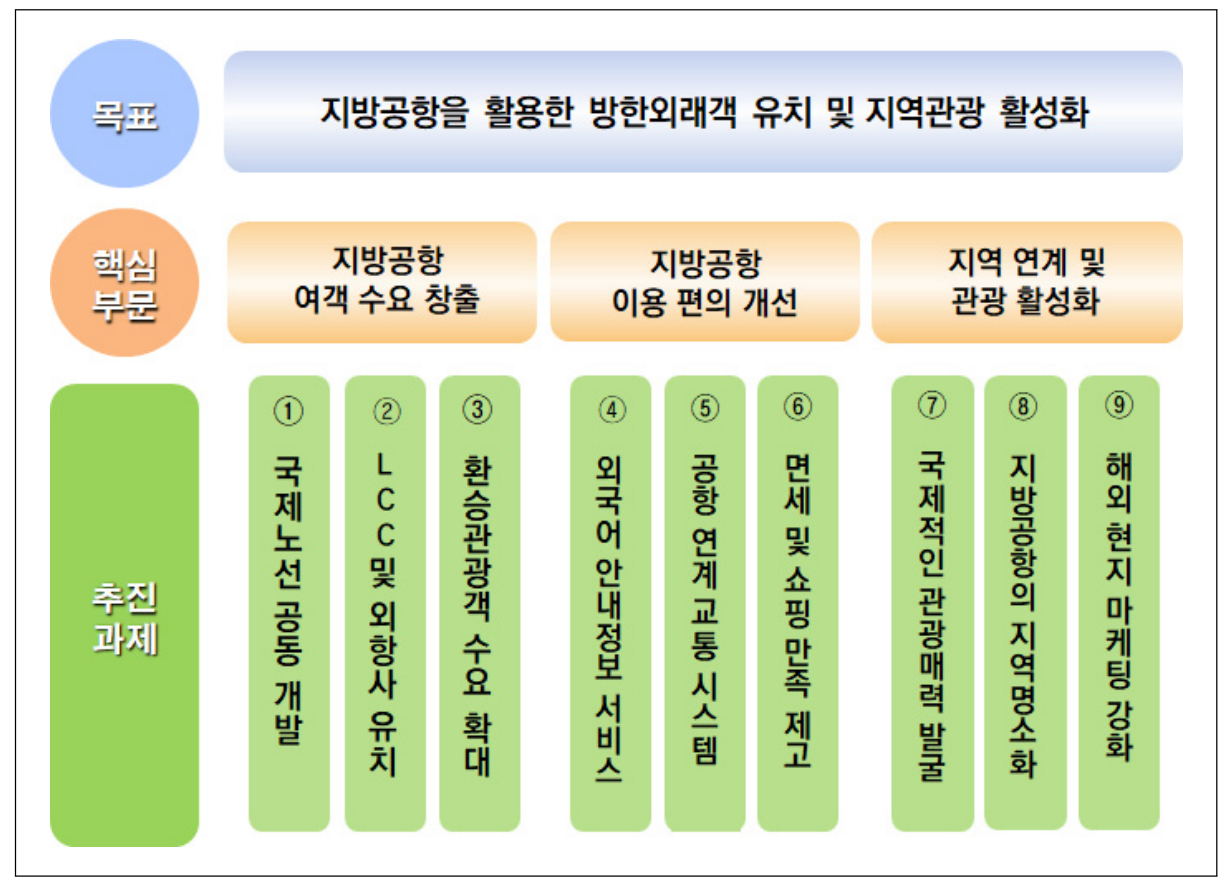




\section{2. 지방공항 여객 수요 창출 \\ 가. 국제노선 공동 개발}

- 국토부와 항공사들이 중심이 되는 국제노선 개발 과정에 문체부, 관광공사, 여행사 등 관광 분야의 전문가들 참여가 이루어질 필요가 있음

- 지방공항의 국제노선을 운영함에 있어서 인바운드 정책 측면에서 유치가 필요 한 전략시장 국가들을 우선적으로 검토하고 취항도시의 경우 지방의 소규모 휴양도시보다는 관광송출 잠재력이 높은 대도시를 선정할 필요가 있음

- 최근 중국과 일본 뿐 아니라 동남아 시장의 유치 중요성이 강조되고 있는 만 큼, 지방공항의 국제노선을 동남아 주요국으로 다변화할 필요가 있음

- Top10 방한시장에 속하는 홍콩, 베트남, 태국의 경우 매년 많은 관광객들이 우리나라를 방문하고 있지만 입국 경로가 여전히 인천공항에 집중된 경향이 높아 향후 지방공항을 활용한 적극적인 유치 노력이 요청됨

\section{나. LCC 및 외항사 유치}

- 향후 저비용항공사(LCC)를 국내 지방공항으로 유치하기 위해서는 항공 운수 권과 공항 슬롯의 문제 해결이 선행되어야 할 것임

- 항공협상으로 확보한 운수권은 항공사에 배분되는데 지방공항에 신규노선이 취항될 수 있도록 운수권 배분에 우선권을 주는 정책을 검토할 필요가 있음

- 특정 공항의 활성화를 위해서는 그 공항에서 기반을 두고 운항하는 항공사가 필수적이며, 전략적 제휴를 통해 항공사의 네트워크를 확장할 필요가 있음

- 국내 지방공항에 저비용항공사 유치를 강화하기 위해서는 공항과 항공사, 지 자체, 관광공사 등 관련 주체들 간의 협력과 공동 마케팅이 중요함

- 공항의 적극적인 사용료 할인과 지자체의 재정적인 지원이 필수적이며, 관광 공사도 저비용항공사와 협력하여 해외 마케팅을 추진해야 할 것임 


\section{다. 환승관광객 수요 확대}

- 항공운송산업은 네트워크 산업이며 규모의 경제를 따르기 때문에 충분하고 다 양한 항공노선이 선결되어야 환승에 유리하며, 또한 환승공항으로서 주변 지 역의 관광인프라도 함께 개발될 필요가 있음

- 이번 연구의 주요 대상인 김해공항의 경우, 대만과 중국으로 연결하는 환승노 선을 추가적으로 개발하여 환승을 유도하고 부산시와 주변 배후지역으로 환승 관광객을 유치하는 전략을 수립할 수 있음

- 지방공항의 환승관광 수요 확대를 위해서는 공항 내 환승 편의시설 확충 및 당일 환승관광 프로그램 개발이 우선적으로 추진되어야 함

- 최근에 개별여행 시장의 증가를 고려하여 해외 현지에서 항공권을 예약 구매 하는 단계에서부터 국내 지방공항의 환승관광 프로그램에 대한 사전 홍보를 강화하고 온라인 예약 시스템을 구축할 필요가 있음

- 당일 환승관광 프로그램의 경우 1 시간부터 5 시간까지 시간대와 테마를 다양 하게 하여 환승객들의 스케줄에 맞는 프로그램을 선택할 수 있도록 해야 함

\section{3. 지방공항 이용 편의 개선}

\section{가. 외국어 안내정보 서비스}

- 향후 방한 개별여행(FIT) 시장 유치에 보다 초점을 두고, 외국인 관광객들이 국내 지방공항에 도착하여 지역여행을 하는데 필요한 안내정보를 편리하게 수집할 수 있도록 공항 내 인프라와 서비스를 개선할 필요가 있음

- 주요 공항에 설치된 안내 키오스크의 경우 지역관광공사와 협력하여 공항 인 근의 대표 관광지에 대한 콘텐츠와 외국어 정보를 보완해야 할 것임

- 특히, 외국인 개별여행객들이 필요로 하는 대중교통, 주변 관광지, 맛집, 숙박 시설, 쇼핑 등에 관한 상세한 안내정보 서비스를 제공할 필요가 있음

- 공항공사에서는 외국어 안내 모바일 앱 서비스를 개발하여 항공편 운항 정보 
뿐 아니라 보안 및 출입국 심사 대기시간, 공항 택시 및 리무진 예약, 수하물 배달 및 보관 등에 관한 실시간 정보 서비스를 검토할 필요가 있음

\section{나. 공항 연계교통 시스템}

- 지방공항을 통해 입국한 외국인 관광객들의 지역관광 접근성 제고를 위해 항 공과 철도를 연계한 예약.발권 시스템을 구축하고 제휴 할인서비스 및 연계 관광상품을 개발할 필요가 있음

- 기존의 공항 리무진 및 일반버스의 경우, 지방공항의 국제선 출·도착 시간에 맞춰 운행 스케줄과 배차 간격을 조정할 필요가 있음

- 지자체에서 공항연계 셔틀버스를 운행할 경우 KTX역, 버스터미널 등 교통거 점을 비롯해 주요 호텔, 관광명소 등을 경유하는 노선을 개발할 필요가 있음

- 향후 개별여행 시장의 증가가 예상됨에 따라 항공과 연계한 렌트카 예약시스 템을 구축하고, 공항 렌트카 이용료 할인 이벤트(예: 최초 1 일 1만원 렌트카) 및 렌트카 여행을 위한 외국어 안내지도를 제공할 필요가 있음

- 또한 공유차량 서비스의 경우 모바일 앱으로 차량 예약시 필요한 외국어 안내 지원 서비스를 도입할 필요가 있음

\section{다. 면세 및 쇼핑 만족 제고}

- 국내 지방공항을 활용하여 관광을 통한 경제적 효과를 높이기 위해서는 공항 인근 도시 및 주변 지역에서의 관광객 소비 지출을 확대할 필요가 있음

- 지자체는 전통 재래시장, 쇼핑거리, 쇼핑몰 등 쇼핑관광 명소를 육성하고 공항 으로부터 접근할 수 있는 대중교통과 외국어 안내 정보를 제공할 필요가 있음

- 지역 내 상점에서 쇼핑한 수화물을 공항까지 직접 배송해주거나, 입국 면세점 에서 구매한 물품을 장기간 보관해주는 서비스 도입도 검토할 필요가 있음

- 지방공항 내에 면세품 인도장, 세금환급(Tax-refund) 부스, 24 시간 운영 환 전소 등 편의시설 및 서비스 개선을 통해 쇼핑 만족도를 높일 수 있음 


\section{4. 지역 연계 및 관광 활성화}

\section{가. 국제적인 관광매력 발굴}

- 최근 정부는 지역관광의 활성화를 위해 관광거점도시 육성, 테마 여행 10선, 지역 관광기업 지원 등 관련 정책사업을 적극적으로 추진해오고 있음

- 국내 지방공항은 외래관광객 유치를 위해 관광거점도시와의 연계를 강화할 필 요가 있으며 유네스코 등재 세계유산, 국제문화·관광축제 등 외국인들의 관심 과 인지도가 높은 명소와 매력 있는 콘텐츠를 적극적으로 발굴할 필요가 있음

- 본 연구의 주요 대상인 김해공항은 국제관광도시인 부산시의 도시 이미지와 관광브랜드 구축을 위한 홍보마케팅 활동의 거점으로 활용될 필요가 있음

- 한편 무안공항의 경우 지역관광거점도시로 지정된 목포시의 시티투어 프로그 램과 구도심 도보관광 코스 등을 연계하여 유치 전략을 수립할 필요가 있음

- 지역관광거점도시인 전주시는 무안공항에서 이동거리가 멀어 접근성은 다소 부족하나 지역 전통문화와 고유한 음식 등 매력적인 관광콘텐츠를 보유하고 있어 외국인을 위한 한옥숙박 체험상품 등을 개발해 볼 수 있음

\section{나. 지방공항의 지역명소화}

- 해당 지자체가 추구하는 도시 이미지와 관광 브랜드 등을 고려하여 공항 내 주요 시설과 서비스, 프로그램 등을 차별화할 필요가 있음

- 동남아를 비롯해 해외에서 한류의 인기가 한국 이미지 개선에 기여하고 있으 며, 따라서 한류가 지방공항의 지역명소화 사업의 좋은 아이템이 될 수 있음

- 본 연구의 주요 대상인 무안공항의 경우 호남의 맛과 음식문화를 체험할 수 있는 식당과 대기시간을 활용해 한국 전통문화를 체험해볼 수 있는 프로그램 등을 도입한다면 외국인 관광객들의 방한 경험을 제고할 수 있음

- 네덜란드의 스키폴, 독일의 프랑크푸르트 등의 사례와 같이 공항 주변에 관광 시설, 숙박시설, 상업시설 등이 복합적으로 개발될 수 있다면 방한 인바운드 관광객 유치 확대에도 긍정적인 효과를 가져올 수 있음 


\section{다. 해외 현지 마케팅 강화}

- 지자체에서는 지방공항의 국제노선을 활용하여 더 많은 외국인 관광객을 유치 하기 위한 해외 홍보 마케팅 활동을 주도적으로 추진할 필요가 있음

- 지방공항에서 운항 중인 저비용항공사의 경우 아웃바운드 수요 뿐 만 아니라 인바운드 수요를 창출하기 위한 해외 현지 마케팅을 강화할 필요가 있음

- 해당 지자체와 관광공사는 지방공항에서 취항 중인 항공사와 공동 협력하여 해외 미디어, 여행업계, SNS 인플루언서, 외국 정부 및 외국 국적 항공사 등 을 대상으로 초청 팸투어 개최를 추진할 필요가 있음

- 국내 주요 방송사, 저비용항공사 등과 함께 BTS와 같은 세계적인 한류스타의 지방공연 이벤트를 활용하여 전세기 방한 관광상품을 개발하는 것도 지방공항 을 연계하는 좋은 방안으로 판단됨

- 정부와 해당 지자체에서는 지방공항 및 항공사, 여행사 등이 공동으로 해외 현지의 소비자 대상 광고와 마케팅 활동을 효과적으로 전개할 수 있도록 재정 적으로 지원하는 방안도 검토해 볼 필요가 있음

\section{5. 주체별 역할 및 협력방안}

\section{가. 관광-항공 협력체계 필요성}

- 관광정책과 항공정책의 우선순위는 다소 차이가 존재하며, 두 분야 간 정책 격차를 좁히고 인바운드 관광 활성화를 위한 정책을 추진할 필요가 있음

- 앞으로는 단순한 부처 간의 정보 공유를 넘어 부처의 의사결정에 영향을 미칠 수 있어야 하며 통합적이고 일관성 있는 정책 추진이 이루어져야 함

- 지방공항을 활용한 외래관광객 유치 확대를 위해서는 중앙정부 차원과 지자체 차원, 공공부문과 민간부문 등 다각적인 협력체계 구축이 필수적임

- 특히 각 지방공항의 지역관광 활성화를 위한 추진체계는 지자체, 지방공항, 지역의 항공사 및 관광업계, 지방공기업 등의 주도적인 참여가 필요함 
[그림 2] 지방공항 관광활성화 협력체계(안)

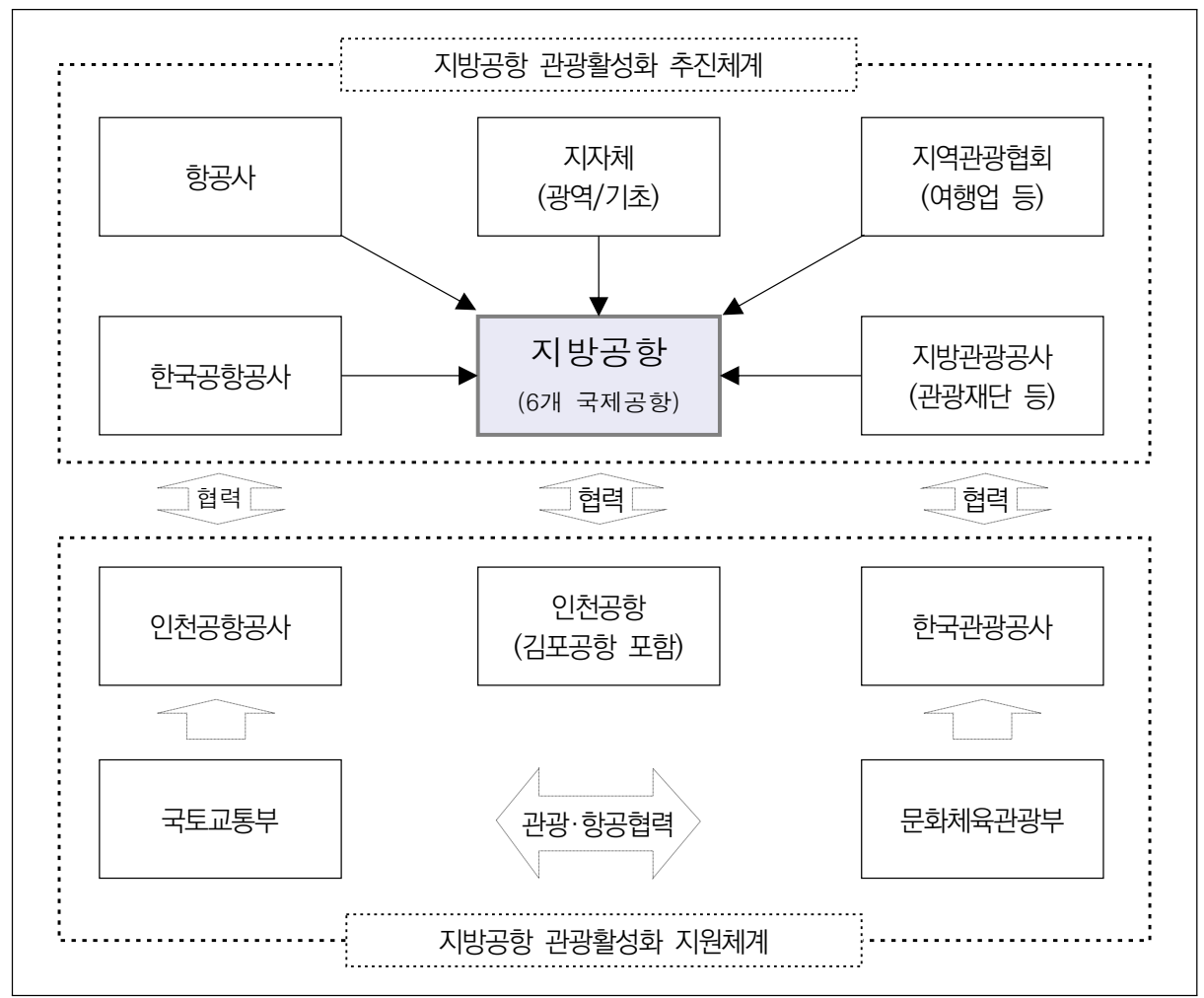

\section{나. 각 주체별 역할과 협력방안}

- 중앙정부 및 산하 공공기관은 지방공항 연계 관광상품의 개발 및 공동홍보 강 화, 공항에서 도심(관광지) 간 교통 및 안내 서비스 개선, 지방공항의 출도착 거점 기능 확대, 지역 기반시설의 관광자원화 사업 등을 추진하여야 함

- 한국관광공사와 한국공항공사는 저비용항공사 및 외국항공사의 유치, 지방공 항의 관광편의 서비스 개선, 지방공항 관광지간 이동편의 개선, 국제관광 홍 보 마케팅, 지방공항 입국자의 식별정보 공유 등을 담당할 필요가 있음

- 외래관광객의 지역 분산을 위해 인천공항과 제주공항 및 김해공항, 김포공항 과 나머지 공항 간 연계 항공편 개설을 통해 지방공항 출입을 확대할 필요가 있음 
- 8 개 국제공항 간 인(In) 아웃(Out) 기능을 교차 수행하는 방안도 확대되어야 하며, 인천공항(김포공항 포함)과 제주공항 간 인·아웃 기능도 활성화될 필요 가 있음

- 향후 지자체들의 지방공항 활성화를 위한 주도적인 역할이 확대되어야 하며, 이를 위해 실무적인 기능을 해당 지역의 공기업이 수행할 수 있도록 해야 함

- 현재 전남관광재단, 부산관광공사 등 대부분 지역에 관광관련 공기업이 설립 되어 있으며, 정부의 관광거점도시 정책과의 연계사업도 적극 추진되어야 함

- 지방공항에서는 허브항공사 유치 전략을 강화하고 신규 취항 및 증편 시 인센 티브를 제공하여 항공사들의 지방공항 국제선 운항을 유도해야 함

- 지방공항에 취항 중인 항공사의 경우, 외래관광객 유치를 위한 해외 마케팅을 보다 강화하고 해당지역의 관광거점도시 사업을 홍보할 필요가 있음

- 무엇보다 지방공항을 활용한 외래관광객 유치를 위해서는 지역의 관광업계를 중심으로 글로벌 관광명소 육성 및 콘텐츠의 지속적인 발굴이 필요함

- 외래관광객들이 선호하는 우수 관광콘텐츠를 지속 발굴하고, 지방공항과 지역 의 관광자원을 연계한 테마형 고부가가치 상품을 개발하는 것이 중요함 



\section{목차}

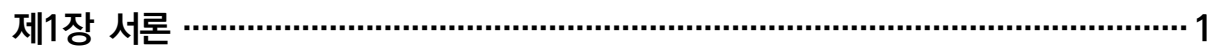

제1절 연구 배경 및 목적 3

1. 연구 배경 3

2. 연구 목적 4

제2절 연구 범위 및 방법 5

1. 연구 범위 5

2. 연구 방법 1

3. 연구 흐름도 8

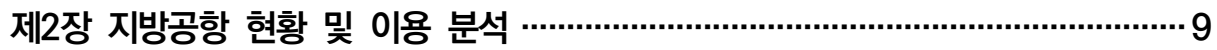

제1절 방한 외래관광객 현황 11

1. 교통수단별 입국자 수 11

2. Top10 방한시장 입국 현황 13

제2절 항공 국제여객노선 현황 18

1. 공항별 국제노선 실적 18

2. 공항별 환승여객 현황 21

제3절 연구대상 지방공항 현황 $\quad 22$

1. 김해국제공항 22

2. 무안국제공항 28

제4절 분석결과 및 시사점 32

제3장 조사 데이터 분석 ………….................................................................... 35

제1절 항공여객 $\mathrm{OD}$ 조사 데이터 심층 분석 37

1. 조사개요 및 분석방법 37

2. 김해공항 분석결과 40

3. 무안공항 분석결과 53 
제2절 지방공항 이용 외국인 심층면접조사

1. 김해공항 이용객 심층면접조사

2. 무안공항 이용객 심층면접조사 76

제3절 분석결과 및 시사점

제4장 외국 유사사례 분석

제1절 조사 개요

제2절 일본 사례 조사

1. 일본의 공항 개요

2. 일본의 지방공항 활용 외래객 유치 전략

101

제3절 태국 사례 조사

1. 태국의 공항 개요

2. 태국의 지방공항 활용 외래객 유치 전략

제4절 호주 사례 조사

1. 호주의 공항 개요

2. 호주의 지방공항 활용 외래객 유치 전략

제5절 분석결과 및 시사점

제5장 향후 정책 추진방안

제1절 목표 및 기본방향

제2절 각 부문별 추진과제

1. 지방공항 여객 수요 창출

2. 지방공항 이용 편의 개선

3. 지역 연계 및 관광 활성화

제3절 주체별 역할과 협력방안

1. 관광-항공 협력체계 필요성

2. 각 주체별 역할과 협력방안 


\section{참고문헌 / 175}

ABSTRACT / 179

\section{부록 / 181}

【부록1】 외국인 심층면접조사 설문지 / 183

【부록2】 태국의 주요 공항별 특성 / 188

【부록3】 호주의 주요 공항별 특성 / 195 


\section{표 목차}

〈표 1-1〉 연구의 대상 범위 5

〈표 1-2〉 위계별 공항의 기능 및 권역별 분포 5

〈표 2-1〉 최근 5년간 교통수단별 입국자 현황 12

〈표 2-2〉 Top1 5 방한시장의 교통수단별 입국자 현황(2019년 기준) 16

〈표 2-3〉Top6 10 방한시장의 교통수단별 입국자 현황(2019년 기준) 17

〈표 2-4〉 최근 5년간 공항별 국제여객노선 운항 실적 18

〈표 2-5〉 최근 5년간 공항별 국제여객노선 여객 실적 19

〈표 2-6〉 공항별 국제여객노선 운항 현황(2019년 기준) 20

〈표 2-7〉 2019년 공항별 환승여객 현황 21

〈표 2-8〉 김해국제공항의 주요시설 현황 22

〈표 2-9〉 김해국제공항 연도별 운항횟수 22

〈표 2-10〉 김해국제공항 연도별 여객실적 23

〈표 2-11〉 김해국제공항 노선별 항공여객 실적 24

〈표 2-12〉 김해공항 국제노선 취항도시 현황(2019년 기준) 25

〈표 2-13〉 김해공항 국제노선 항공사별 통계(2019년 기준) 25

〈표 2-14〉 김해공항 접근 교통수단 26

〈표 2-15〉 무안국제공항의 주요시설 현황 28

〈표 2-16〉 무안국제공항 연도별 운항횟수 28

〈표 2-17〉 무안국제공항 연도별 여객실적 29

〈표 2-18〉 무안국제공항 노선별 항공여객 실적 29

〈표 2-19〉 무안공항 국제노선 취항도시 현황(2019년 기준) 30

〈표 2-20〉무안공항 국제노선 항공사별 통계(2019년 기준) 31

〈표 3-1〉 조사 횟수 37

〈표 3-2〉조사 설문 구조 및 내용 38

〈표 3-3〉 심층 분석 조사 항목 38

〈표 3-4〉 척도 문항에 대한 100점 점수 변환 39

〈표 3-5〉 부정응답, 보통, 긍정응답 정의 39 
〈표 3-6〉 김해공항 응답자 특성 40

〈표 3-7〉 공항 이동 교통수단별 불만족 이유_김해공항 50

〈표 3-8〉 무안공항 응답자 특성 53

〈표 3-9〉 김해공항 심층면접조사 응답자 66

〈표 3-10〉해외 현지에서 한국 여행 정보를 얻은 경로 67

〈표 3-11〉 해당 경로를 사용한 이유 67

〈표 3-12〉 한국 방문 전 필요한 정보와 정보 획득시 어려운 점 68

〈표 3-13〉 최근 입/출국시 이용한 항공사 68

〈표 3-14〉 해당 항공사를 이용한 이유 69

〈표 3-15〉이용해본 항공사별 장단점 69

〈표 3-16〉 공항시설 및 서비스에 대한 평가 70

〈표 3-17〉 김해공항 이용 외국인 관광객을 위한 개선점 70

〈표 3-18〉 공항에서 주변 관광지를 방문시 가장 필요한 정보 71

〈표 3-19〉 관광지 정보획득의 어려운 점 71

〈표 3-20〉 관광지 정보획득 개선사항 72

〈표 3-21〉이용한 교통수단에 대한 평가 72

〈표 3-22〉 공항 접근성 및 연계교통 관련 개선점 73

〈표 3-23〉 공항 인근 지역 여행시 가장 좋았던 점 73

〈표 3-24〉 공항 인근 지역 여행시 가장 불편했던 점 74

〈표 3-25〉 국내 타 공항과 비교시 장/단점 74

〈표 3-26〉외국인을 지방으로 유치하기 위해 필요한 정책 75

〈표 3-27〉 무안공항 심층면접조사 응답자 76

〈표 3-28〉 해외 현지에서 한국 여행 정보를 얻은 경로 76

〈표 3-29〉 해당 경로를 사용한 이유 77

〈표 3-30〉한국 방문 전 필요한 정보 획득시 어려운 점 77

〈표 3-31〉 최근 입/출국시 이용한 항공사 78

〈표 3-32〉 해당 항공사를 이용한 이유 78

〈표 3-33〉이용해본 항공사별 장단점 78

〈표 3-34〉 공항시설 및 서비스에 대한 평가 79

〈표 3-35〉무안공항 이용 외국인 관광객을 위한 개선점 79

〈표 3-36〉 공항 이용 시 주변 도시나 지역 관광지에 대한 정보 획득 80

〈표 3-37〉 공항에서 주변 관광지를 방문시 가장 필요한 정보 80

〈표 3-38〉 관광지 정보획득의 어려운 점 80 
〈표 3-39〉 관광지 정보획득 개선사항 81

〈표 3-40〉이용한 교통수단에 대한 평가 81

〈표 3-41〉 공항 접근성 및 연계교통 관련 개선점 82

〈표 3-42〉 공항 인근 지역 여행시 가장 좋았던 점 82

〈표 3-43〉 공항 인근 지역 여행시 가장 불편했던 점 83

〈표 3-44〉 무안공항에서 출국할 경우 예상되는 어려운 점 83

〈표 3-45〉 국내 타 공항과 비교시, 장/단점 84

〈표 3-46〉 외국인을 지방으로 유치하기 위해 필요한 정책 85

〈표 4-1〉외국사례 조사 분석항목 92

〈표 4-2〉 간사이공항 일본국적 항공사의 운항 점유율 94

〈표 4-3〉 간사이공항의 국적별 항공사 구분 95

〈표 4-4〉간사이공항의 한국노선 운항 현황 96

〈표 4-5〉간사이공항의 중국노선 운항 현황 97

〈표 4-6〉 간사이공항의 기타 아시아노선 운항 현황 99

〈표 4-7〉 간사이공항의 구미주·오세아니아노선 운항 현황 100

〈표 4-8〉태국 주요 공항의 항공기 운항 현황 109

〈표 4-9〉태국 주요 공항의 여객수송 현황 111

〈표 4-10〉태국 주요 공항의 Slot 및 여객처리 수용능력 현황 112

〈표 4-11〉태국 주요 공항의 면적 및 활주로 현황 113

〈표 4-12〉호주 주요 국제공항의 연간 항공기 운항 현황 124

〈표 4-13〉호주 9개 국제공항의 국제여객 수송 현황 126

〈표 4-14〉외국사례 조사를 통한 주요 시사점 135

〈표 5-1〉 우리나라 항공자유화 협정 체결 현황 143

〈표 5-2〉 지방공항 활성화 사업 재정 지원 현황 148

〈표 5-3〉 한국 여행 준비 중 가장 필요했던 정보 151

〈표 5-4〉 관광 및 항공부문의 정책 격차 163 


\section{그림 목차}

[그림 1-1] 연구 흐름도

[그림 2-1] 최근 10년간 항공을 통한 입국자 수 비중 변화 11

[그림 2-2] 2015년 교통수단별 입국자 비율 12

[그림 2-3] 2019년 교통수단별 입국자 비율 12

[그림 2-4] 2015년 지방공항별 입국자 비율 13

[그림 2-5] 2019년 지방공항별 입국자 비율 13

[그림 2-6] 중국시장 지방공항별 입국자 비율 14

[그림 2-7] 일본시장 지방공항별 입국자 비율 14

[그림 2-8] 대만시장 지방공항별 입국자 비율 14

[그림 2-9] 미국시장 지방공항별 입국자 비율 14

[그림 2-10] 홍콩시장 지방공항별 입국자 비율 14

[그림 2-11] 태국시장 지방공항별 입국자 비율 14

[그림 2-12] 베트남시장 지방공항별 입국자 비율 15

[그림 2-13] 필리핀시장 지방공항별 입국자 비율 15

[그림 2-14] 말레이시아시장 지방항공별 입국자 비율 15

[그림 2-15] 러시아시장 지방공항별 입국자 비율 15

[그림 2-16] 2019년 국제선 공항 이용실적 19

[그림 2-17] 김해국제공항 연간 운항횟수 추이 23

[그림 2-18] 김해국제공항 연간 여객실적 추이 23

[그림 2-19] 무안국제공항 연간 운항횟수 추이 28

[그림 2-20] 무안국제공항 연간 여객실적 추이 29

[그림 3-1] 여행 목적_김해공항 42

[그림 3-2] 여행 동반자 형태_김해공항 42

[그림 3-3] 여행 인원_김해공항 43

[그림 3-4] 여행 형태_김해공항 43

[그림 3-5] 여행 기간_김해공항 44

[그림 3-6] 방한 빈도_김해공항 44 
[그림 3-7] 항공권 구입 경로_김해공항

[그림 3-8] 국내 입국 공항_김해공항

[그림 3-9] 국내 입국 시 환승 여부_김해공항

[그림 3-10] 국내 방문지(시도별)_김해공항

[그림 3-11] 국내 방문지까지 이용 교통수단_김해공항

[그림 3-12] 방문지까지 이용 교통수단별 만족도_김해공항

[그림 3-13] 공항으로 출발지역(시도별)_김해공항

[그림 3-14] 공항 이동 교통수단_김해공항

[그림 3-15] 공항 이동 교통수단 이용 이유_김해공항 49

[그림 3-16] 공항 이동 교통수단 이용 만족도_김해공항 49

[그림 3-17] 공항 이동 소요시간_김해공항 50

[그림 3-18] 최종 목적지 국가_김해공항 51

[그림 3-19] 한국 외 타 국가 방문 여부_김해공항 51

[그림 3-20] 타 국가 방문 시 환승 여부_김해공항 52

[그림 3-21] 환승 유형_김해공항 52

[그림 3-22] 환승 공항 선택 이유_김해공항 53

[그림 3-23] 여행 목적_무안공항 55

[그림 3-24] 여행 동반자 형태_무안공항 55

[그림 3-25] 여행 인원_무안공항 56

[그림 3-26] 여행 형태_무안공항 56

[그림 3-27] 여행 기간_무안공항 57

[그림 3-28] 방한 빈도_무안공항 57

[그림 3-29] 항공권 구입 경로_무안공항 58

[그림 3-30] 국내 입국 공항_무안공항 58

[그림 3-31] 국내 입국 시 환승 여부_무안공항 59

[그림 3-32] 국내 방문지(시도별)_무안공항 59

[그림 3-33] 방문지까지 이용 교통수단_무안공항 60

[그림 3-34] 방문지까지 이용 교통수단별 만족도_무안공항 60

[그림 3-35] 공항으로 출발지역(시도별)_무안공항 61

[그림 3-36] 공항 이동 교통수단_무안공항 61

[그림 3-37] 공항 이동 교통수단 이용 이유_무안공항 62

[그림 3-38] 공항 이동 교통수단 이용 만족도_무안공항 62

[그림 3-39] 공항 이동 소요시간_무안공항 63 
[그림 3-40] 최종 목적지 국가_무안공항

[그림 3-41] 한국 외 타 국가 방문 여부_무안공항 64

[그림 3-42] 타 국가 방문 시 환승 여부_무안공항 64

[그림 3-43] 환승 유형_무안공항 65

[그림 3-44] 환승 공항 선택 이유_무안공항 65

[그림 4-1] 사가공항 입국 외국인 수 추이 103

[그림 4-2] 요나고공항 입국 외국인 수 추이 104

[그림 4-3] 태국의 국제공항 현황 107

[그림 4-4] 보안 및 입국 심사대 실시간 대기 현황 안내 115

[그림 4-5] 공항 주차가능 대수 현황 116

[그림 4-6] 수하물 배달(핸즈프리) 서비스 116

[그림 4-7] 공항 택시 예약 서비스 116

[그림 4-8] 리무진, 수하물, 렌터카 서비스 116

[그림 4-9] 'GrabTukTuk’ 3륜 전기오토바이 117

[그림 4-10] 태국의 여성관광객 유치 캠페인 119

[그림 4-11] 제주항공과 몽키트래블 제휴이벤트 120

[그림 4-12] 호주의 국제공항 현황 122

[그림 4-13] 호주 캔버라 공항에 설치된 작품 128

[그림 4-14] TravelbyBit의 브리즈번 공항 홍보 포스터 129

[그림 4-15] Uber Air 전기 비행택시 130

[그림 4-16] Mystery Breaks 로고 132

[그림 4-17] Mystery Breaks 도착 공항 132

[그림 5-1] 핵심 부문별 추진과제 140

[그림 5-2] 아시아태평양 지역의 연간 LCC 공급좌석 수 변화 145

[그림 5-3] 태국 지방공항의 중국인 전용 입국심사대 152

[그림 5-4] 도심과 주요 호텔을 연결하는 공항셔틀버스 154

[그림 5-5] 부산 국제관광도시와 신안군 섬 어드벤처 158

[그림 5-6] 싱가포르 창이공항의 Forest Valley와 Rain Vortex 160

[그림 5-7] 지방공항 관광활성화 협력체계(안) 164 

지방공항을 활용한 지역관광 활성화 방안

\section{제1장}

서론 



\section{제1절 연구 배경 및 목적}

\section{1. 연구 배경}

방한 외국인 관광객 수는 2009년 약 781만 명에서 2019년 약 1,750만 명으로 최근 10 년간 두 배 이상 증가하였으나, 외국인 관광객들의 방문 지역은 여전히 서 울 수도권 등 일부 지역에 편중되고 있다. 2018년 기준 외래객 지역별 방문율이 서울 $79.4 \%$, 경기 $14.9 \%$, 부산 $14.7 \%$, 강원 9.7\% 등 순으로 나타난 바와 같이, 방한 외국인 관광객의 서울 수도권 집중 현상이 고착화되면서 국내 지방공항의 관 문 역할 및 거점 기능 강화를 위한 정책이 요구되고 있다.

그러나 권역별 거점공항으로 지정된 대다수 지방공항들이 국내선 운항 위주로 운 영되고 있어 방한 외국인 관광객의 유치에 한계를 보이고 있다. 실제로 각 공항별 국제노선 비중이 김해공항 $57.2 \%$, 대구공항 $50.4 \%$, 제주공항 $7.5 \%$, 무안공항 $14.6 \%$ 등 순으로 나타난다. 또한 방한 외국인 관광객들이 국내 지방공항을 이용하 게 될 경우 출입국 절차, 안내 정보, 연계 교통, 면세 쇼핑 등 전반적인 관광수용태 세가 미흡하여 개선이 필요한 실정이다.

지방공항은 방한 외국인 관광객의 지역 방문을 촉진하는 중요한 관문으로서, 관 광 및 항공 분야 간의 협력과 연계 정책 수립이 요청된다. 정부는 2019년 12월 국 무총리 주재로 '제4차 국가관광전략회의'를 개최하고, 「여행자 중심 지역관광 발전 전략」을 발표하였다. 특히, 항공 분야와 관련하여 지방공항 입국 외래객 환대 기간 및 대규모 홍보 행사를 추진하고, 지방공항 출도착 항공 노선을 확충하며, 지방공항 환승관광 프로그램을 시범 도입할 계획이다.

한편, 국토교통부는 「제3차 항공정책기본계획(20 24)」에서 "미래항공 글로벌 선 도 국가"를 비전으로 5대 목표와 30개 추진과제를 제시한 바 있다. 동 계획에서는 항공과 관광의 융복합을 강조하고 협업과제를 제시하고 있는데, 지속가능한 항공수 
요 창출을 위해 기존의 아웃바운드 중심에서 인바운드 신규 수요 유치를 위한 정책 을 강화할 계획이다. 또한, 기존의 운송사업 위주 정책에서 항공산업 전·후방 연관 생태계를 포괄 육성해나갈 방침이며 여행 및 숙박, 식음료, 면세 등 연관사업 활동 에 대한 지원을 확대할 계획이다.

\section{2. 연구 목적}

본 연구의 목적은 국내 지방공항의 관문 역할을 강화함으로써 방한 외래관광객 유치를 도모하고 지역관광을 활성화하기 위한 정책방안을 제시하는데 있다. 보다 구체적으로 본 연구의 세부 목적은 다음과 같다.

첫째, 방한 외래관광객들의 지방공항 이용 및 지역관광 실태를 진단하고, 주요 문 제점과 개선사항을 도출하고자 한다.

둘째, 지방공항의 국제노선 운항 현황을 분석하고, 방한 외래관광객 유치 관점에 서 한계점과 개선사항을 검토하고자 한다.

셋째, 외국의 우수사례를 조사하고, 지방공항을 활용한 외래관광객 지역 유치를 위한 정책 방향과 추진과제를 제시하고자 한다. 


\section{제2절 연구 범위 및 방법}

\section{1. 연구 범위}

\section{가. 공간적 범위}

국내 공항은 인천국제공항을 포함하여 총 15 개이며, 그 중에 국제공항은 8 개이 다. 본 연구의 목적을 고려할 때, 방한 외래관광객 유치 확대 측면에서 향후 정부의 '관광거점도시' 정책과 연계 가능한 지방공항을 중심으로 살펴볼 필요가 있다. 따라 서 이번 연구에서는 '대도시형 지방공항'의 대표적인 사례인 김해공항과 '지역연계 형 지방공항 유형의 하나인 무안공항을 주요 대상으로 선정하였다.

〈표 1-1〉 연구의 대상 범위

\begin{tabular}{c|c|c}
\hline 전체 국내 공항(15) & 지방 국제공항(8) & 주요 연구대상(2) \\
\hline $\begin{array}{c}\text { 인천, 김포, 청주, 원주, 양양, 무안, 군산, 광주, } \\
\text { 여수, 사천, 대구, 김해, 포항, 울산, 제주 }\end{array}$ & $\begin{array}{c}\text { 인천, 김포, 청주, 양양, } \\
\text { 무안, 대구, 김해, 제주 }\end{array}$ & 김해, 무안 \\
\hline
\end{tabular}

〈표 1-2〉 위계별 공항의 기능 및 권역별 분포

\begin{tabular}{|c|c|c|c|}
\hline 구분 & 성격 & 세부 기능 & 권역별 분포 \\
\hline 중추공항 & $\begin{array}{c}\text { 글로벌 항공시장에서 } \\
\text { 국가를 대표 }\end{array}$ & $\begin{array}{l}\text { 전 세계 항공 시장을 대상 } \\
\text { 으로 하며 동북아지역의 허브 }\end{array}$ & (중부권) 인천공항 \\
\hline 거점공항 & 권역 내 거점 & $\begin{array}{c}\text { 권역의 국내선 수요 및 } \\
\text { 중단거리 국제선 수요 처리 }\end{array}$ & $\begin{array}{l}\text { (중부권) 김포공항, 청주공항 } \\
\text { (동남권) 김해공항, 대구공항 } \\
\text { (서남권) 무안공항 } \\
\text { (제주권) 제주공항, 제주 제2공항1) }\end{array}$ \\
\hline 일반공항 & 주변지역 수요 담당 & $\begin{array}{c}\text { 주변지역의 } \\
\text { 국내선 수요 위주 처리 }\end{array}$ & $\begin{array}{r}\text { (중부권) 원주공항, 양양공항 } \\
\text { (동남권) 울산공항, 포항공항, } \\
\text { 사천공항, 울릉공항 } \\
\text { (서남권) 광주공항, 여수공항, } \\
\text { 군산공항, 흑산공항 }\end{array}$ \\
\hline
\end{tabular}

자료: 국토교통부, 제5차 공항개발 중장기 종합계획 
또한, 지방공항의 여객터미널을 연구의 주요 공간대상으로 삼되 항공편을 통한 외래관광객의 출입국 여정(기내 포함) 및 지방공항 주변의 배후도심이나 주요 관광 지로 이동하는 연계 교통까지 포함하여 고려하고자 한다.

\section{나. 시간적 범위}

- 2019년 기준 최신 자료 활용

\section{다. 내용적 범위}

- 국내 지방공항 현황 분석

- 교통수단별 입국자 수, 주요 방한시장 입국 현황

- 공항별 국제노선 실적, 공항별 환승여객 현황

- 연구대상 지방공항 관광편의시설 및 서비스 현황

- 외국인 이용자 조사 분석

- 「2019 항공여객OD 및 특성조사」데이터 심층분석

- 지방공항 이용 경험 외국인 개별 심층인터뷰 조사

- 해외 유사사례 조사 분석

- 일본 공항 세일즈 정책, 간사이 공항 국제노선 운항

- 태국 공항별 특성, 지방공항 활용 외래객 유치 정책

- 호주 공항별 특성, 지방공항 활용 외래객 유치 정책

- 지방공항을 활용한 외래관광객 유치 방안

- 국제노선 공동 개발, LCC 유치 등을 통한 여객 수요 창출

- 외국어 안내, 연계교통 서비스 등 지방공항 이용 편의 개선

- 관광매력 홍보, 지방공항 명소화 등을 통한 지역관광 활성화

- 관광 및 항공 분야 간의 협업을 위한 거버넌스 구축 운영

1) 제주공항과 제주 제2공항은 향후 역할 분담방안에 대한 검토를 거쳐 위계를 결정. 


\section{2. 연구 방법}

\section{가. 문헌자료 분석}

본 연구를 위해 우선 문체부 및 국토부의 정책 동향 및 관련 계획에 관한 문헌자 료를 검토하였으며, 지역관광 활성화 관점에서 지방공항의 현황 진단을 위해 출입 국 관광통계 및 항공통계 자료를 분석하였다. 또한 외국의 유사사례 조사를 위해 인터넷 문헌자료와 언론기사 등을 토대로 분석하였다.

\section{나. 현장방문 조사}

본 연구의 주요 대상인 김해공항과 무안공항을 직접 방문하여 외국인 관광객 관 점에서 공항 내 관광편의시설 및 서비스 현황을 점검하였으며, 해당 지방공항의 운 영 현황 및 관광 분야와의 협력 현황에 관하여 한국공항공사 관계자들을 대상으로 면담 인터뷰 조사를 실시하였다.

\section{다. 전문가 자문회의}

본 연구의 진행 과정에서 관광 및 항공 분야의 다양한 전문가들을 대상으로 연구 자문회의를 개최하였다. 한국교통연구원과 한국공항공사, 한국항공협회, 민간 항공 사, 항공안전기술원, 한국항공대학교, 인하공업전문대학, 한국관광공사, 지역관광공 사/재단 등 각계 전문가들의 의견을 수렴하였다.

\section{라. 조사데이터 심층 분석}

방한 외래관광객들의 항공편 이동경로, 공항접근 교통수단 등을 구체적으로 파악 하고 지방공항 이용 관련 주요 개선사항을 도출하기 위하여 한국항공협회에서 주관 한「2019 항공여객 OD 및 특성조사」 데이터를 연구 목적에 맞게 재분석하였다.

\section{마. 외국인 개별 인터뷰 조사}

코로나 19 의 확산 영향으로 인해 방한 외래관광객 대상 직접 설문조사가 불가능 하여, 그 대안으로 최근 지방공항 이용 경험이 있는 외국인을 대상으로 개별 심층 인터뷰 조사를 실시하여 구체적인 지역관광 실태와 주요 개선점을 분석하였다. 


\section{3. 연구 흐름도}

본 연구는 총 6 개의 장으로 구성되며, 전체적인 연구의 추진 절차와 수행 방법은 다음 [그림 1-1]과 같다.

[그림 1-1] 연구 흐름도

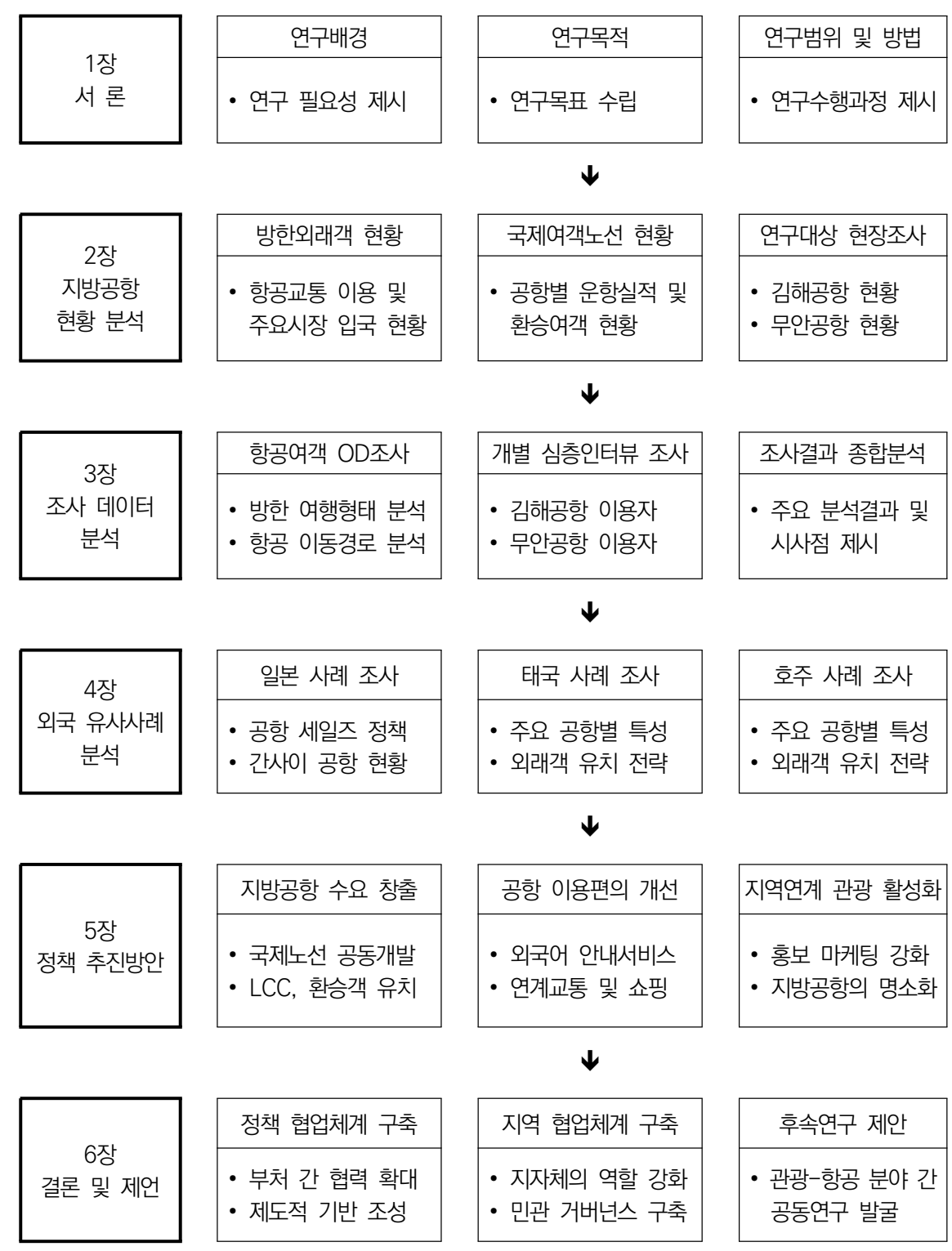


지방공항을 활용한 지역관광 활성화 방안

제2장

지방공항 현황 및

이용 분석 



\section{제1절 방한 외래관광객 현황}

\section{1. 교통수단별 입국자 수}

전체 방한 외래관광객의 약 $90 \%$ 가 공항을 통해 입국하고 있으며, 여러 교통수단 가운데 항공이 차지하는 비율은 2015년 81.1\%, 2016년 79.6\%, 2017년 88.3\%, 2018년 90.9\%, 2019년 89.9\%로 최근 증가 추세를 보이고 있다.

우리나라의 국제공항은 인천공항을 포함하여 총 8곳이며, 허브공항 기능을 담당 하고 있는 인천공항을 통해 입국한 비율이 약 $67 \%$ 로 가장 높게 나타난다. 방한 외 국인 관광객들의 입국 관문으로서 국내 지방공항의 역할은 매우 미미한 실정이며, 김해공항과 제주공항 등 일부 공항에 한정되어 있다.

- 2019년 기준: 김해공항 $7.7 \%$, 제주공항 $7.0 \%$, 김포공항 $6.7 \%$, 대구공항 $1.1 \%$, 청주공항 $0.5 \%$ 등의 순

[그림 2-1] 최근 10년간 항공을 통한 입국자 수 비중 변화

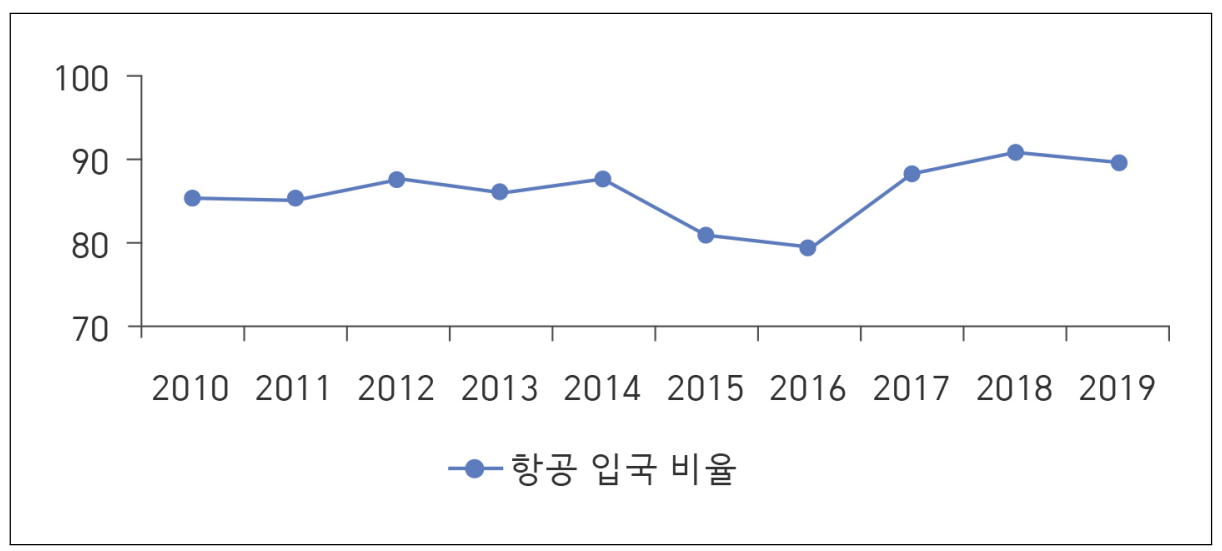


[그림 2-2] 2015년 교통수단별 입국자 비율

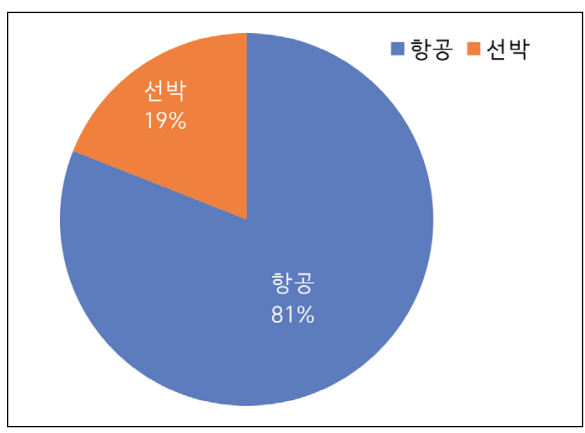

[그림 2-3] 2019년 교통수단별 입국자 비율

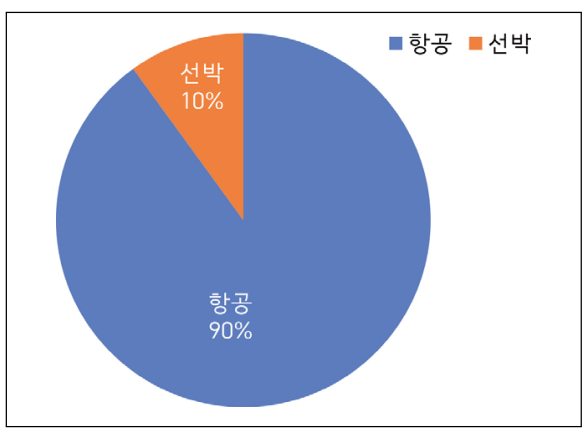

〈표 2-1〉 최근 5년간 교통수단별 입국자 현황

\begin{tabular}{|c|c|c|c|c|c|c|c|}
\hline \multicolumn{3}{|c|}{ 구분 } & 2015년 & 2016년 & 2017년 & 2018년 & 2019년 \\
\hline \multirow{2}{*}{\multicolumn{2}{|c|}{ 인청항 }} & 인원(명) & 7,667,973 & $9,862,596$ & $9,086,053$ & $10,550,384$ & $11,672,601$ \\
\hline & & 구성비(\%) & 57.95 & 57.20 & 68.13 & 68.75 & 66.69 \\
\hline \multirow{2}{*}{\multicolumn{2}{|c|}{ 김퐁항 }} & 인원(명) & 971,881 & $1,056,106$ & 945,481 & $1,101,506$ & $1,173,054$ \\
\hline & & 구성비(\%) & 7.35 & 6.13 & 7.09 & 7.18 & 6.70 \\
\hline \multirow{2}{*}{\multicolumn{2}{|c|}{ 김행항 }} & 인원(명) & 791,062 & $1,056,549$ & $1,052,591$ & $1,263,630$ & $1,350,263$ \\
\hline & & 구성비(\%) & 5.98 & 6.13 & 7.89 & 8.23 & 7.71 \\
\hline \multirow{6}{*}{ 항공 } & \multirow{2}{*}{$\begin{array}{l}\text { 제줌 } \\
\text { 공항 }\end{array}$} & 인원(명) & 962,129 & $1,328,318$ & 557,200 & 840,940 & $1,218,438$ \\
\hline & & 구성비(\%) & 7.27 & 7.70 & 4.18 & 5.48 & 6.96 \\
\hline & \multirow{2}{*}{$\begin{array}{l}\text { 대국 } \\
\text { 공항 }\end{array}$} & 인원(명) & 50,521 & 102,704 & 68,595 & 106,145 & 199,631 \\
\hline & & 구성비(\%) & 0.38 & 0.60 & 0.51 & 0.69 & 1.14 \\
\hline & \multirow{2}{*}{$\begin{array}{l}\text { 청중 } \\
\text { 공항 }\end{array}$} & 인원(명) & 191,535 & 232,688 & 57,751 & 63,732 & 84,539 \\
\hline & & 구성비(\%) & 1.45 & 1.35 & 0.43 & 0.42 & 0.48 \\
\hline & \multirow{2}{*}{$\begin{array}{l}\text { 양ㅇㅑㅑ } \\
\text { 공항 } \\
\end{array}$} & 인원(명) & 47,007 & 34,147 & 2,442 & 13,658 & 12,105 \\
\hline & & 구성비(\%) & 0.36 & 0.20 & 0.02 & 0.09 & 0.07 \\
\hline & \multirow{2}{*}{$\begin{array}{l}\text { 무안 } \\
\text { 공항 }\end{array}$} & 인원(명) & 37,559 & 34,064 & 3,924 & 7,674 & 20,268 \\
\hline & & 구성비(\%) & 0.28 & 0.20 & 0.03 & 0.05 & 0.12 \\
\hline & \multirow{2}{*}{$\begin{array}{l}\text { 기타 } \\
\text { 공항 }\end{array}$} & 인원(명) & 12,801 & 7,769 & 7,842 & 8,075 & 8,798 \\
\hline & & 구성비(\%) & 0.10 & 0.05 & 0.06 & 0.05 & 0.05 \\
\hline & \multirow{2}{*}{ 소계 } & 인원(명) & $10,732,468$ & $13,714,941$ & $11,781,879$ & $13,955,744$ & $15,739,697$ \\
\hline & & 구성비(\%) & 81.11 & 79.55 & 88.34 & 90.94 & 89.92 \\
\hline \multirow{2}{*}{\multicolumn{2}{|c|}{ 선박 }} & 인원(명) & $2,494,840$ & $3,521,736$ & $1,550,967$ & $1,391,098$ & $1,763,000$ \\
\hline & & 구성비(\%) & 18.86 & 20.42 & 11.63 & 9.06 & 10.07 \\
\hline \multirow{2}{*}{\multicolumn{2}{|c|}{ 기타 }} & 인원(명) & 4,343 & 5,146 & 2,912 & 37 & 59 \\
\hline & & 구성비(\%) & 0.03 & 0.03 & 0.02 & 0.00 & 0.00 \\
\hline \multirow{2}{*}{\multicolumn{2}{|c|}{ 전체 }} & 인원(명) & $13,231,651$ & $17,241,823$ & $13,335,758$ & $15,346,879$ & $17,502,756$ \\
\hline & & 구성비(\%) & 100 & 100 & 100 & 100 & 100 \\
\hline
\end{tabular}

자료: 법무부 자료를 기초로 한 출입국 관광통계 
[그림 2-4] 2015년 지방공항별 입국자 비율

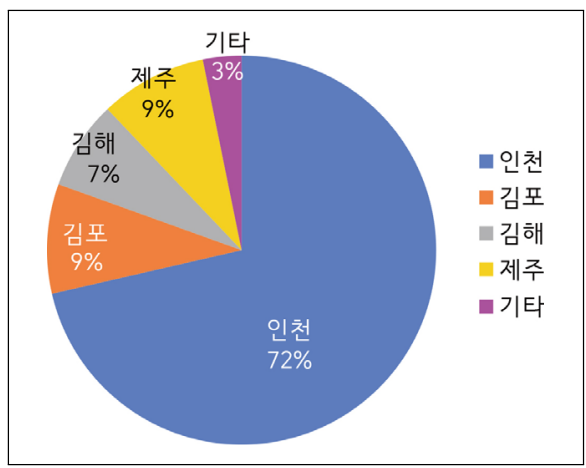

[그림 2-5] 2019년 지방공항별 입국자 비율

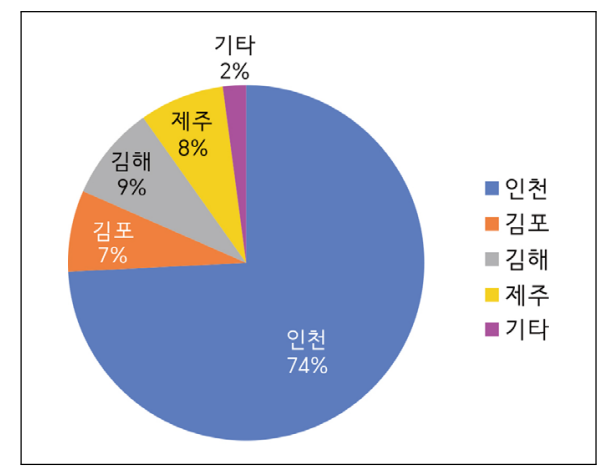

\section{Top10 방한시장 입국 현황}

중국시장의 경우, 인천공항을 통해 입국한 비율이 $59.3 \%$ 로 가장 높고 그 다음으 로 제주공항 $15.2 \%$, 김포공항 $4.5 \%$, 김해공항 $3.4 \%$ 순으로 나타났다. 특히, 중국 은 Top5 다른 국가들에 비해 제주공항 입국 비율이 상대적으로 높은 것으로 분석 된다.

일본시장의 경우, 인천공항을 통해 입국한 비율이 $58.7 \%$ 로 가장 높고 그 다음으로 김포공항 $21.4 \%$, 김해공항 $12.2 \%$, 제주공항 $1.6 \%$ 순으로 나타났다. 방한 일본인의 경우 인천공항, 김포공항 등 서울 수도권을 통해 입국한 비율이 약 $80 \%$ 에 이른다.

대만시장의 경우, 인천공항을 통해 입국한 비율이 $59.8 \%$ 로 가장 높고 그 다음으 로 김해공항 $19.1 \%$, 대구공항 $7.3 \%$, 김포공항 $4.8 \%$ 순으로 나타났다.

미국시장의 경우, 인천공항을 통해 입국한 비율이 $86.0 \%$ 로 매우 높았으며 김해 공항 $3.9 \%$, 김포공항 $3.8 \%$ 등의 순으로 나타났다. 장거리 시장인 미국은 Top5 국 가들 가운데 인천공항 입국 비율이 가장 높은 것으로 분석된다.

홍콩시장의 경우, 인천공항을 통해 입국한 비율이 $83.6 \%$ 로 매우 높았으며 김해 공항 $8.5 \%$, 제주공항 $6.5 \%$ 등의 순으로 나타났다. 홍콩은 중국, 일본, 대만시장과 비교할 때 인천공항 입국 비율이 상대적으로 높은 것으로 분석된다.

태국시장의 경우, 인천공항을 통해 입국한 비율이 $79.6 \%$ 로 가장 높고 그 다음으 로 김해공항 $10.4 \%$, 제주공항 $7.4 \%$, 대구공항 $1.0 \%$ 순으로 나타났다. 
[그림 2-6] 중국시장 지방공항별 입국자 비율

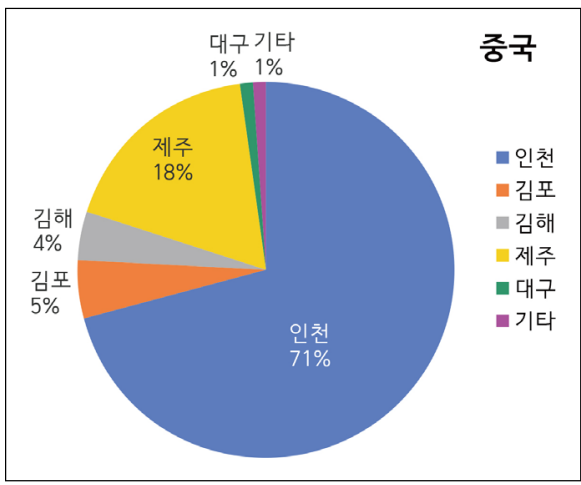

[그림 2-8] 대만시장 지방공항별 입국자 비율

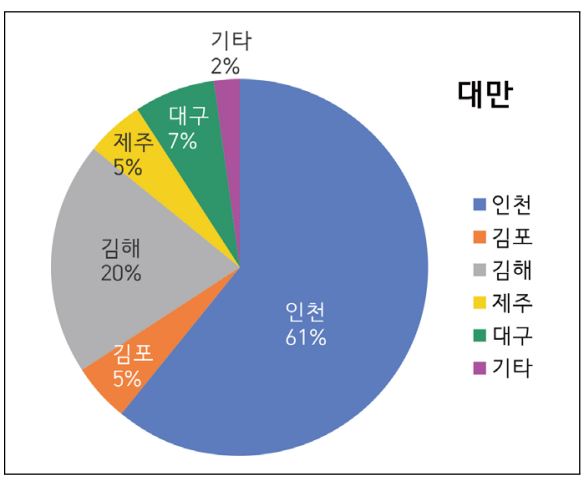

[그림 2-10] 홍콩시장 지방공항별 입국자 비율

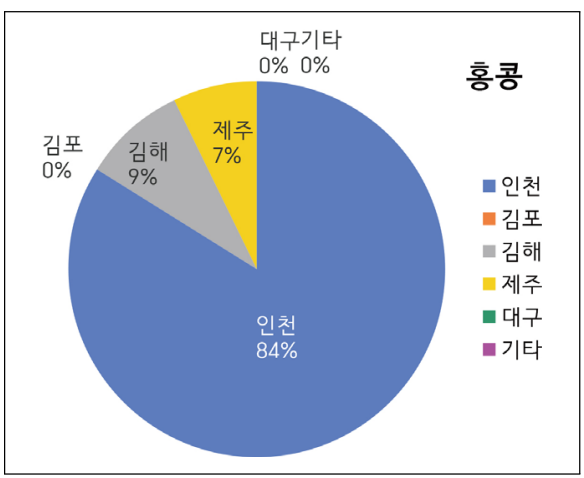

[그림 2-7] 일본시장 지방공항별 입국자 비율

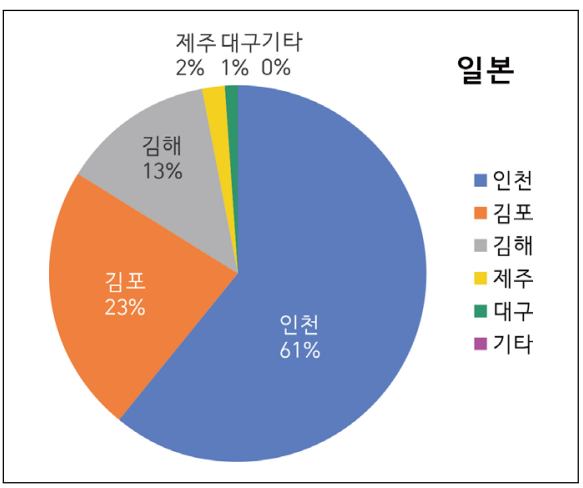

[그림 2-9] 미국시장 지방공항별 입국자 비율

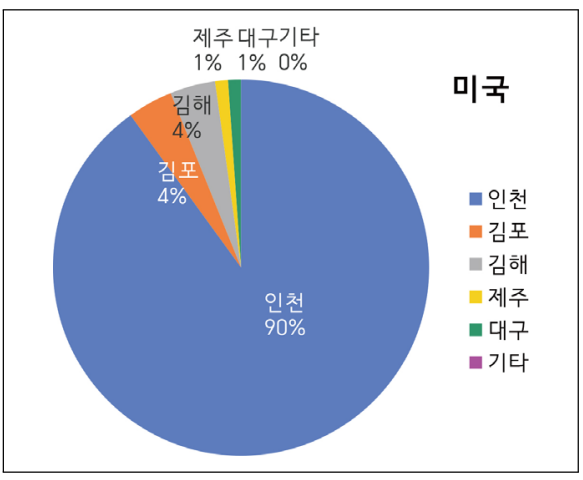

[그림 2-11] 태국시장 지방공항별 입국자 비율

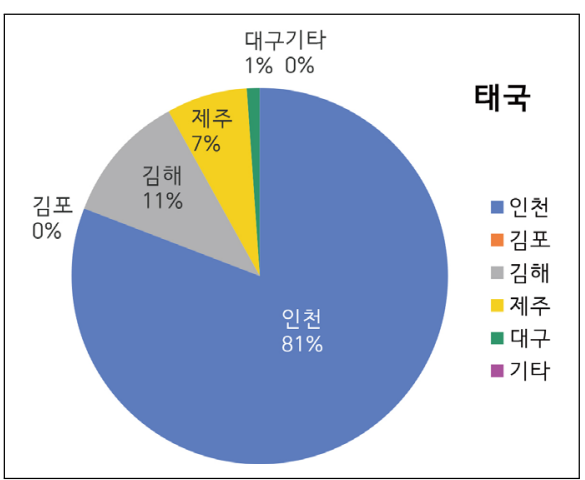


베트남시장의 경우, 인천공항을 통해 입국한 비율이 $82.0 \%$ 로 가장 높고 그 다음 으로 김해공항 $11.8 \%$, 대구공항 $1.6 \%$, 양양공항 $1.5 \%$ 순으로 나타났다. 2019 년에 는 양양공항을 통해 방한 베트남 관광객 8,336명이 입국하였다.

필리핀시장의 경우, 인천공항을 통해 입국한 비율이 55.8\%로 Top10 국가들 가 운데 가장 낮았으며 그 다음으로 김해공항 $4.8 \%$ 로 나타났다. 특히, 필리핀은 기타 교통수단(선박)을 통해 입국한 비율이 매우 높은 것으로 분석된다.

말레이시아시장의 경우, 인천공항을 통해 입국한 비율이 $75.5 \%$ 로 가장 높고 그 다음으로 김해공항 $11.7 \%$, 제주공항 $11.6 \%$ 등의 순으로 나타났다.

러시아시장의 경우, 인천공항을 통해 입국한 비율이 $67.1 \%$ 로 가장 높았으며 그 다음으로 김해공항 $12.4 \%$ 로 나타났다. 특히, 러시아는 기타 교통수단(선박)을 통해 입국한 비율이 필리핀시장 다음으로 높게 나타났다.

[그림 2-12] 베트남시장 지방공항별 입국자 비율

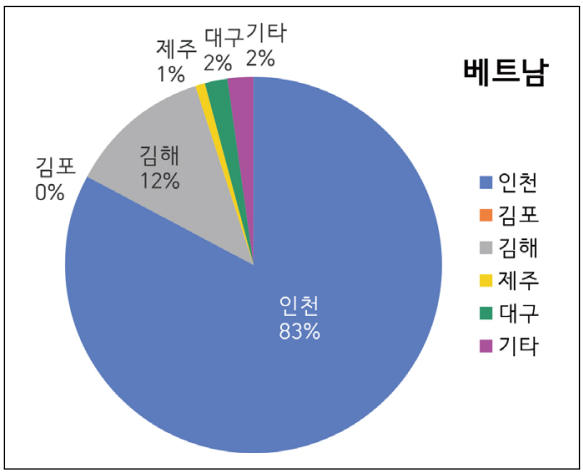

[그림 2-14] 말레이시아시장 지방항공별 입국자 비율

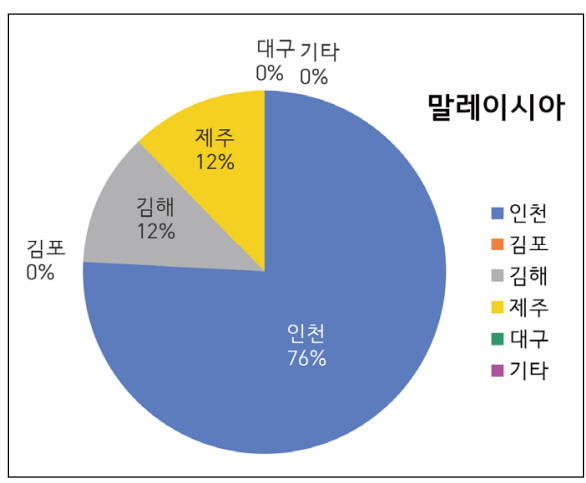

[그림 2-13] 필리핀시장 지방공항별 입국자 비율

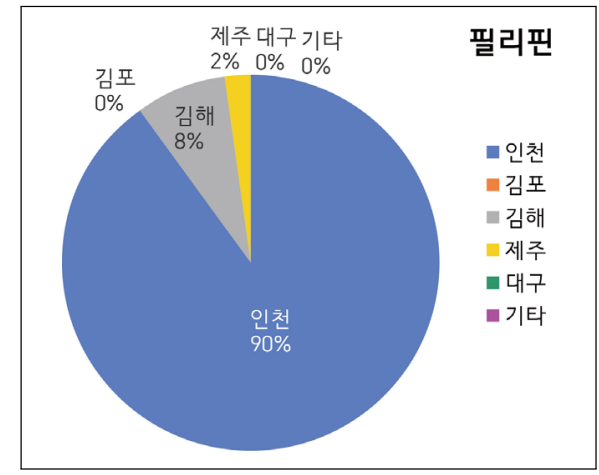

[그림 2-15] 러시아시장 지방공항별 입국자 비율

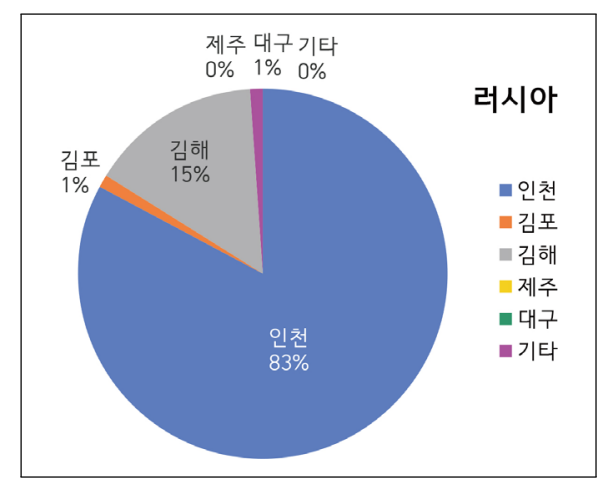


〈표 2-2〉 Top1 5 방한시장의 교통수단별 입국자 현황(2019년 기준)

\begin{tabular}{|c|c|c|c|c|c|c|c|}
\hline \multicolumn{3}{|c|}{ 구분 } & 중국 & 일본 & 대만 & 미국 & 홍콩 \\
\hline \multirow{16}{*}{ 항공 } & \multirow{2}{*}{$\begin{array}{l}\text { 인천 } \\
\text { 공항 }\end{array}$} & 인원(명) & $3,573,012$ & $1,919,052$ & 753,866 & 898,268 & 580,941 \\
\hline & & 구성비(\%) & 59.32 & 58.66 & 59.81 & 86.04 & 83.60 \\
\hline & \multirow{2}{*}{$\begin{array}{l}\text { 김포 } \\
\text { 공항 }\end{array}$} & 인원(명) & 272,321 & 700,364 & 60,225 & 39,316 & 3,557 \\
\hline & & 구성비(\%) & 4.52 & 21.40 & 4.78 & 3.77 & 0.51 \\
\hline & \multirow{2}{*}{$\begin{array}{l}\text { 김해 } \\
\text { 공항 }\end{array}$} & 인원(명) & 202,780 & 400,269 & 240,877 & 40,316 & 58,931 \\
\hline & & 구성비(\%) & 3.37 & 12.23 & 19.11 & 3.86 & 8.48 \\
\hline & \multirow{2}{*}{$\begin{array}{l}\text { 제주 } \\
\text { 공항 }\end{array}$} & 인원(명) & 913,766 & 52,904 & 58,558 & 8,613 & 45,139 \\
\hline & & 구성비(\%) & 15.17 & 1.62 & 4.65 & 0.82 & 6.50 \\
\hline & \multirow{2}{*}{$\begin{array}{l}\text { 대구 } \\
\text { 공항 }\end{array}$} & 인원(명) & 22,639 & 43,244 & 92,476 & 9,103 & 1,853 \\
\hline & & 구성비(\%) & 0.38 & 1.32 & 7.34 & 0.87 & 0.27 \\
\hline & \multirow{2}{*}{$\begin{array}{l}\text { 청주 } \\
\text { 공항 }\end{array}$} & 인원(명) & 67,071 & 2,016 & 12,817 & 497 & 36 \\
\hline & & 구성비(\%) & 1.11 & 0.06 & 1.02 & 0.05 & 0.01 \\
\hline & \multirow{2}{*}{$\begin{array}{l}\text { 양양 } \\
\text { 공항 }\end{array}$} & 인원(명) & 2,536 & 28 & 914 & 34 & 190 \\
\hline & & 구성비(\%) & 0.04 & 0.00 & 0.07 & 0.00 & 0.03 \\
\hline & \multirow{2}{*}{$\begin{array}{l}\text { 무안 } \\
\text { 공항 }\end{array}$} & 인원(명) & 932 & 6,549 & 7,139 & 504 & 131 \\
\hline & & 구성비(\%) & 0.02 & 0.20 & 0.57 & 0.05 & 0.02 \\
\hline \multirow{2}{*}{\multicolumn{2}{|c|}{$\begin{array}{c}\text { 기타 } \\
\text { (선박 등) }\end{array}$}} & 인원(명) & 967,964 & 147,280 & 33,621 & 47,387 & 4,156 \\
\hline & & 구성비(\%) & 16.07 & 4.51 & 2.65 & 4.54 & 0.58 \\
\hline \multirow{2}{*}{\multicolumn{2}{|c|}{ 전체 }} & 인원(명) & $6,023,021$ & $3,271,706$ & $1,260,493$ & $1,044,038$ & 694,934 \\
\hline & & 구성비(\%) & 100 & 100 & 100 & 100 & 100 \\
\hline
\end{tabular}

자료: 법무부 자료를 기초로 한 출입국 관광통계 
〈표 2-3〉Top6 10 방한시장의 교통수단별 입국자 현황(2019년 기준)

\begin{tabular}{|c|c|c|c|c|c|c|c|}
\hline \multicolumn{3}{|c|}{ 구분 } & 태국 & 베트남 & 필리핀 & 말레이시아 & 러시아 \\
\hline \multirow{16}{*}{ 항공 } & \multirow{2}{*}{$\begin{array}{l}\text { 인천 } \\
\text { 공항 }\end{array}$} & 인원(명) & 454,976 & 454,160 & 281,108 & 308,621 & 230,130 \\
\hline & & 구성비(\%) & 79.59 & 82.01 & 55.79 & 75.53 & 67.08 \\
\hline & \multirow{2}{*}{$\begin{array}{l}\text { 김포 } \\
\text { 몽항 }\end{array}$} & 인원(명) & 1,395 & 1,146 & 961 & 1.632 & 1,365 \\
\hline & & 구성비(\%) & 0.24 & 0.21 & 0.19 & 0.40 & 0.40 \\
\hline & \multirow{2}{*}{$\begin{array}{l}\text { 김해 } \\
\text { 공항 }\end{array}$} & 인원(명) & 59,437 & 65,295 & 24,089 & 47,720 & 42,584 \\
\hline & & 구성비(\%) & 10.40 & 11.79 & 4.78 & 11.68 & 12.41 \\
\hline & \multirow{2}{*}{$\begin{array}{l}\text { 제주 } \\
\text { 공항 }\end{array}$} & 인원(명) & 42,273 & 6,628 & 4,526 & 47,187 & 818 \\
\hline & & 구성비(\%) & 7.40 & 1.20 & 0.90 & 11.55 & 0.24 \\
\hline & \multirow{2}{*}{$\begin{array}{l}\text { 대구 } \\
\text { 공항 }\end{array}$} & 인원(명) & 5,872 & 8,785 & 543 & 475 & 1,534 \\
\hline & & 구성비(\%) & 1.03 & 1.59 & 0.11 & 0.12 & 0.45 \\
\hline & \multirow{2}{*}{$\begin{array}{l}\text { 청주 } \\
\text { 공항 }\end{array}$} & 인원(명) & 62 & 671 & 11 & 97 & 36 \\
\hline & & 구성비(\%) & 0.01 & 0.12 & 0.00 & 0.02 & 0.01 \\
\hline & \multirow{2}{*}{$\begin{array}{l}\text { 양양 } \\
\text { 공항 }\end{array}$} & 인원(명) & 0 & 8,336 & 0 & 0 & 12 \\
\hline & & 구성비(\%) & 0.00 & 1.51 & 0.00 & 0.00 & 0.00 \\
\hline & \multirow{2}{*}{$\begin{array}{l}\text { 무안 } \\
\text { 공항 }\end{array}$} & 인원(명) & 1,060 & 479 & 125 & 127 & 402 \\
\hline & & 구성비(\%) & 0.19 & 0.09 & 0.02 & 0.03 & 0.12 \\
\hline \multirow{2}{*}{\multicolumn{2}{|c|}{$\begin{array}{c}\text { 기타 } \\
\text { (선박 등) }\end{array}$}} & 인원(명) & 6,535 & 8,231 & 192,504 & 4,361 & 66,176 \\
\hline & & 구성비(\%) & 1.14 & 1.48 & 38.21 & 0.67 & 19.29 \\
\hline \multirow{2}{*}{\multicolumn{2}{|c|}{ 전체 }} & 인원(명) & 571,610 & 553,731 & 503,867 & 408,590 & 343,057 \\
\hline & & 구성비(\%) & 100 & 100 & 100 & 100 & 100 \\
\hline
\end{tabular}

자료: 법무부 자료를 기초로 한 출입국 관광통계 


\section{제2절 항공 국제여객노선 현황}

\section{1. 공항별 국제노선 실적}

한국공항공사의 항공통계에 따르면, 우리나라 전체 국제여객노선 운항 실적은 2015년 353,148편에서 2019년 492,898편으로 크게 증가하였다. 각 공항별 국제 여객노선 운항 실적을 비교하면 인천공항(73.7\%)이 가장 많고, 김해공항(13.0\%), 김포공항(4.1\%), 대구공항(3.7\%), 제주공항(3.6\%) 순으로 나타났다.

〈표 2-4〉최근 5년간 공항별 국제여객노선 운항 실적

(단위: 편수)

\begin{tabular}{c|c|c|c|c|c}
\hline \multirow{2}{*}{ 구분 } & \multicolumn{5}{|c}{ 공항별 국제여객노선 운항 실적 } \\
\cline { 2 - 6 } & 2015년 & 2016년 & 2017년 & 2018년 & 2019년 \\
\hline 인천공항 & 265,782 & 299,454 & 319,927 & 345,395 & 363,478 \\
\hline 김포공항 & 20,379 & 20,512 & 20,371 & 20,279 & 20,301 \\
\hline 김해공항 & 43,585 & 53,082 & 58,518 & 63,481 & 64,161 \\
\hline 제주공항 & 14,663 & 19,161 & 9,726 & 12,554 & 17,528 \\
\hline 대구공항 & 2,734 & 4,948 & 10,269 & 13,513 & 18,035 \\
\hline 무안공항 & 1,425 & 1,601 & 1,286 & 2,308 & 5,195 \\
\hline 청주공항 & 3,822 & 4,409 & 1,579 & 2,868 & 3,935 \\
\hline 양양공항 & 750 & 606 & 179 & 335 & 261 \\
\hline 기타(울산) & 0 & 0 & 0 & 0 & 4 \\
\hline 합계 & 353,148 & 403,779 & 421,857 & 460,733 & 492,898 \\
\hline
\end{tabular}

자료: 한국공항공사 항공통계

또한, 항공통계 자료에 의하면 우리나라 전체 국제여객노선 여객 실적은 2015년 총 6,183만 명에서 2019년 총 9,090만 명으로 성장하였다. 각 공항별 국제여객노 선 여객 실적을 비교하면 인천공항(77.6\%)이 가장 많고, 김해공항(10.6\%), 김포공 항(4.7\%), 제주공항(2.9\%), 대구공항(2.8\%) 순으로 나타났다. 
〈표 2-5〉 최근 5년간 공항별 국제여객노선 여객 실적

(단위: 명)

\begin{tabular}{c|c|c|c|c|c}
\hline \multirow{2}{*}{ 구분 } & \multicolumn{5}{|c}{ 공항별 국제여객노선 여객 실적 } \\
\cline { 2 - 6 } & 2015년 & 2016년 & 2017년 & 2018년 & 2019년 \\
\hline 인천공항 & $48,720,319$ & $57,152,206$ & $61,520,572$ & $67,676,147$ & $70,578,050$ \\
\hline 김포공항 & $4,029,502$ & $4,241,725$ & $4,032,680$ & $4,290,296$ & $4,272,289$ \\
\hline 김해공항 & $5,958,156$ & $7,776,962$ & $8,813,086$ & $9,866,879$ & $9,590,550$ \\
\hline 제주공항 & $1,993,851$ & $2,741,885$ & $1,276,952$ & $1,899,478$ & $2,668,053$ \\
\hline 대구공항 & 331,550 & 684,841 & $1,503,769$ & $2,048,625$ & $2,575,616$ \\
\hline 무안공항 & 182,797 & 195,021 & 156,949 & 326,522 & 687,280 \\
\hline 청주공항 & 507,631 & 614,060 & 185,940 & 318,089 & 495,613 \\
\hline 양양공항 & 106,620 & 87,747 & 15,780 & 37,533 & 32,305 \\
\hline 기타(울산) & 0 & 0 & 0 & 0 & 566 \\
\hline 합계 & $61,831,586$ & $73,495,106$ & $77,505,956$ & $86,463,569$ & $90,900,322$ \\
\hline
\end{tabular}

자료: 한국공항공사 항공통계

[그림 2-16] 2019년 국제선 공항 이용실적

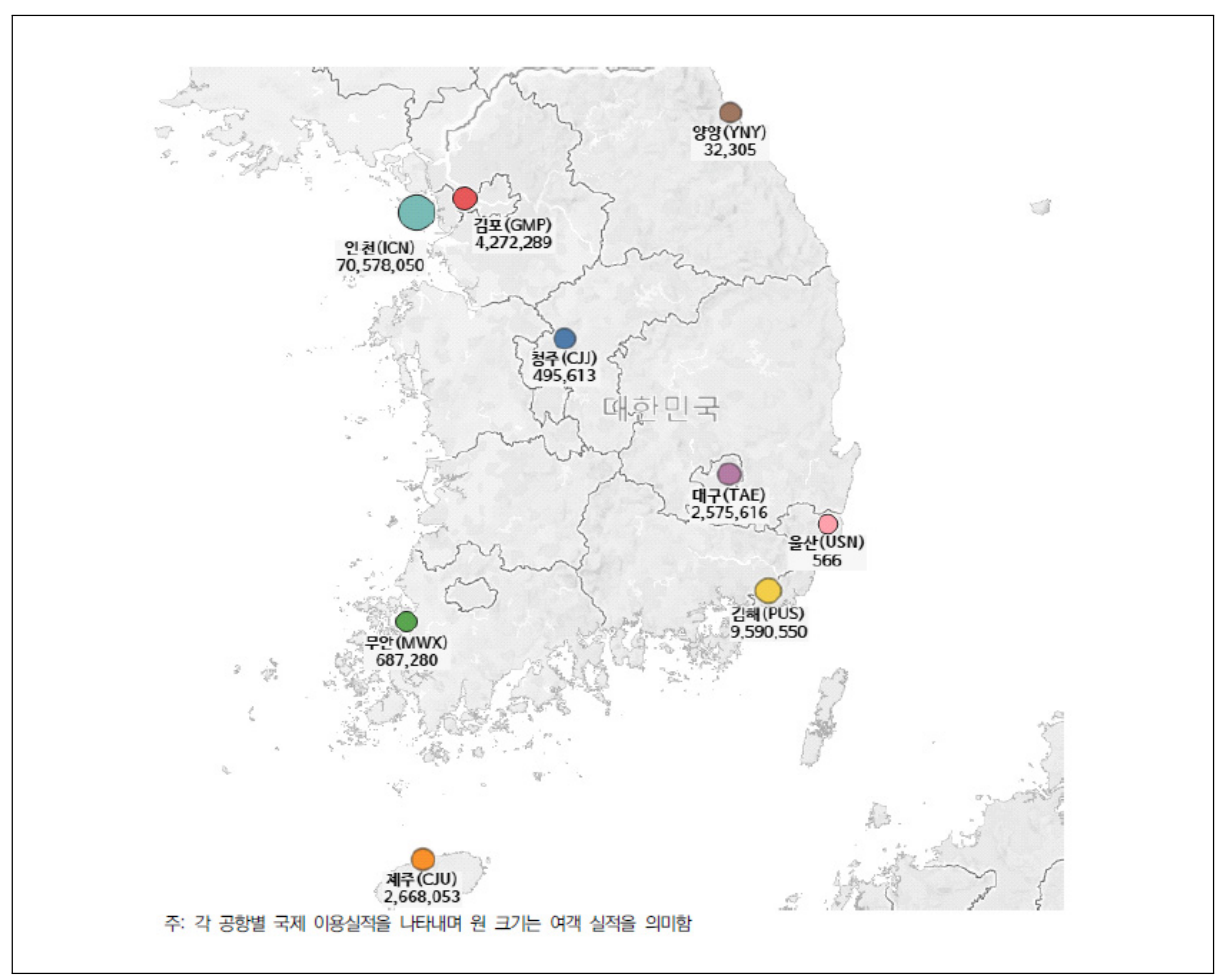

그림: 국토교통부, 2019년 항공교통서비스 보고서 
2019년 기준 각 공항별 국제여객노선 운항 현황을 살펴보면, 인천공항이 363,478 편으로 전체 국제여객노선의 약 $73.7 \%$ 를 차지하고 있다. 이번 연구의 주 요 대상인 김해공항은 64,161 편, 무안공항은 5,195 편으로 나타났다.

또한, 같은 해 각 공항별 국제여객노선 여객 통계에 따르면 인천공항이 7,058만 명으로 전체 국제여객 수의 약 $77.6 \%$ 를 차지하고 있다. 본 연구의 주요 대상인 김 해공항은 959만 명, 무안공항은 69만 명으로 집계되었다.

〈표 2-6〉 공항별 국제여객노선 운항 현황(2019년 기준)

\begin{tabular}{c|c|c|c|c|c|c}
\hline \multirow{2}{*}{ 구분 } & \multicolumn{3}{|c|}{ 운항(편수) } & \multicolumn{3}{c}{ 여객(명) } \\
\cline { 2 - 7 } & 도착 & 출발 & 계 & 도착 & 출발 & 계 \\
\hline 인천공항 & 181,762 & 181,716 & 363,478 & $35,288,279$ & $35,289,771$ & $70,578,050$ \\
\hline 김포공항 & 10,171 & 10,130 & 20,301 & $2,133,626$ & $2,138,663$ & $4,272,289$ \\
\hline 김해공항 & 32,043 & 32,118 & 64,161 & $4,813,037$ & $4,777,513$ & $9,590,550$ \\
\hline 제주공항 & 8,763 & 8,765 & 17,528 & $1,347,491$ & $1,320,562$ & $2,668,053$ \\
\hline 대구공항 & 9,016 & 9,019 & 18,035 & $1,292,142$ & $1,283,474$ & $2,575,616$ \\
\hline 무안공항 & 2,595 & 2,600 & 5,195 & 341,856 & 345,424 & 687,280 \\
\hline 청주공항 & 1,965 & 1,970 & 3,935 & 250,829 & 244,784 & 495,613 \\
\hline 양양공항 & 132 & 129 & 261 & 17,041 & 15,264 & 32,305 \\
\hline 기타(울산) & 2 & 2 & 4 & 284 & 282 & 566 \\
\hline 합계 & 246,449 & 246,449 & 492,898 & $45,484,585$ & $45,415,737$ & $90,900,322$ \\
\hline
\end{tabular}

자료: 한국공항공사 항공통계 


\section{2. 공항별 환승여객 현황}

공항공사 통계자료에 따르면 2019년 기준 전체 환승(통과)여객 수는 총 739만 명이며, 그 중에 인천공항이 약 726 만 명으로 $98.3 \%$ 를 차지하고 있다.

〈표 2-7〉 2019년 공항별 환승여객 현황

\begin{tabular}{c|c|c|c}
\hline \multirow{2}{*}{ 구분 } & \multicolumn{3}{|c}{ 환승(통과)여객 (단위: 명) } \\
\cline { 2 - 4 } & 환승여객(T/S) & 통과여객(Direct T/S) & 계 \\
\hline 인천공항 & $7,196,121$ & 68,854 & $7,264,975$ \\
\hline 김포공항 & 38,079 & 2 & 38,081 \\
\hline 김해공항 & 80,376 & 786 & 81,162 \\
\hline 제주공항 & 6,689 & 1,459 & 8,148 \\
\hline 대구공항 & 45 & 115 & 160 \\
\hline 무안공항 & 2 & 0 & 2 \\
\hline 청주공항 & 2 & 186 & 188 \\
\hline 양양공항 & 0 & 3 & 3 \\
\hline 기타(울산) & 0 & 0 & 0 \\
\hline 합계 & $7,321,314$ & 71,405 & $7,392,719$ \\
\hline
\end{tabular}

자료: 한국공항공사 항공통계, 인천국제공항공사 내부자료 


\section{제3절 연구대상 지방공항 현황}

\section{1. 김해국제공항}

김해국제공항(PUS/RKPK)은 부산광역시 강서구에 위치하고 있으며, 두 개 활주 로와 항공기 38대 동시주기능력을 갖춘 계류장을 보유하고 있다. 김해국제공항 내 국제여객터미널은 연간 총 630만 명의 여객 수용이 가능하며, 주차장은 동시에 5,789 대가 주차할 수 있는 면적을 갖추고 있다.

〈표 2-8〉 김해국제공항의 주요시설 현황

\begin{tabular}{c|c|c|c|c|c|c}
\hline 활주로 & \multicolumn{2}{|c|}{ 국제여객터미널 } & \multicolumn{2}{|c|}{ 계류장 } & \multicolumn{2}{|c}{ 주차장 } \\
\hline $\begin{array}{c}\text { Runways } \\
(\mathrm{m})\end{array}$ & $\begin{array}{c}\text { 면적 } \\
\left(\mathrm{m}^{2}\right)\end{array}$ & $\begin{array}{c}\text { 수용능력 } \\
(\text { 만 명/년) }\end{array}$ & $\begin{array}{c}\text { 면적 } \\
\left(\mathrm{m}^{2}\right)\end{array}$ & $\begin{array}{c}\text { 동시주기능력 } \\
(\text { 대})\end{array}$ & $\begin{array}{c}\text { 면적 } \\
\left(\mathrm{m}^{2}\right)\end{array}$ & $\begin{array}{c}\text { 동시주차능력 } \\
(\text { 대})\end{array}$ \\
\hline $\begin{array}{c}3,200 \times 60 \\
2,745 \times 46\end{array}$ & 72,001 & 630 & 389,358 & $\begin{array}{c}38 \\
\text { (일반35, 소형3) }\end{array}$ & 163,261 & 5,789 \\
\hline
\end{tabular}

자료: 항공정보포털시스템, 2019년 12월 기준

김해국제공항의 연도별 운항횟수 실적을 보면 지속적인 증가 추세를 보이고 있으 며, 특히 2015년부터 2017년까지 가파른 성장을 기록하였다.

〈표 2-9〉 김해국제공항 연도별 운항횟수

\begin{tabular}{c|c|c|c|c|c|c|c}
\hline 2011년 & 2012년 & 2013년 & 2014년 & 2015년 & 2016년 & 2017년 & 2018년 회) \\
\hline 66,525 & 71,713 & 77,665 & 78,646 & 87,709 & 99,358 & 107,363 & 110,924 \\
\hline
\end{tabular}


[그림 2-17] 김해국제공항 연간 운항횟수 추이

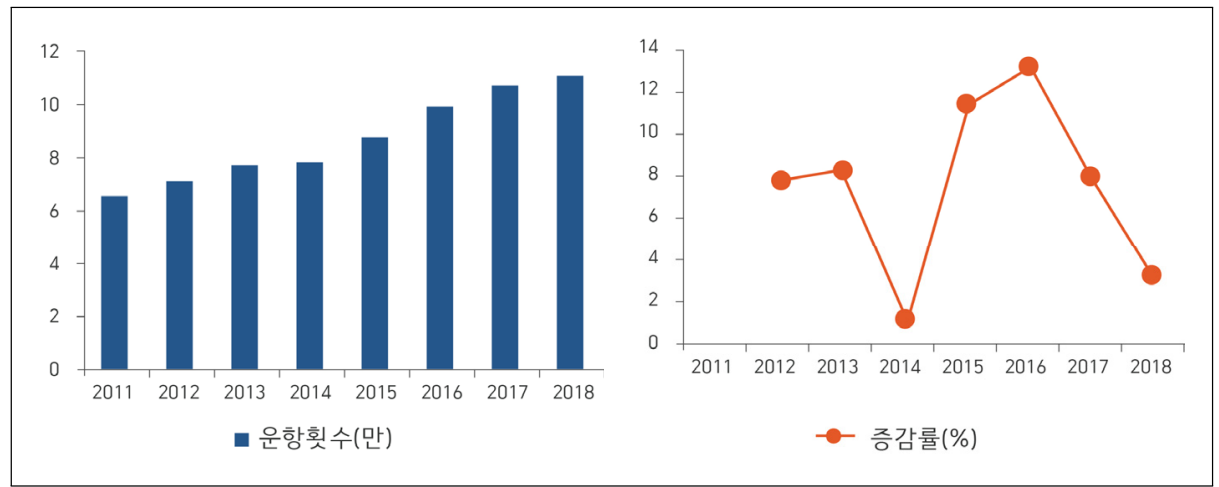

김해국제공항의 연간 여객실적 역시 꾸준한 증가 추세를 보이고 있으며, 특히 2015년부터 2017년까지 전년대비 빠른 성장을 기록하였다.

〈표 2-10〉 김해국제공항 연도별 여객실적

(단위: 명)

\begin{tabular}{c|c|c|c|c|c|c|c}
\hline 2011년 & 2012년 & 2013년 & 2014년 & 2015년 & 2016년 & 2017년 & 2018년 \\
\hline $8,749,153$ & $9,196,090$ & $9,671,381$ & $10,378,866$ & $12,382,150$ & $14,900,815$ & $16,403,541$ & $17,064,613$ \\
\hline
\end{tabular}

[그림 2-18] 김해국제공항 연간 여객실적 추이

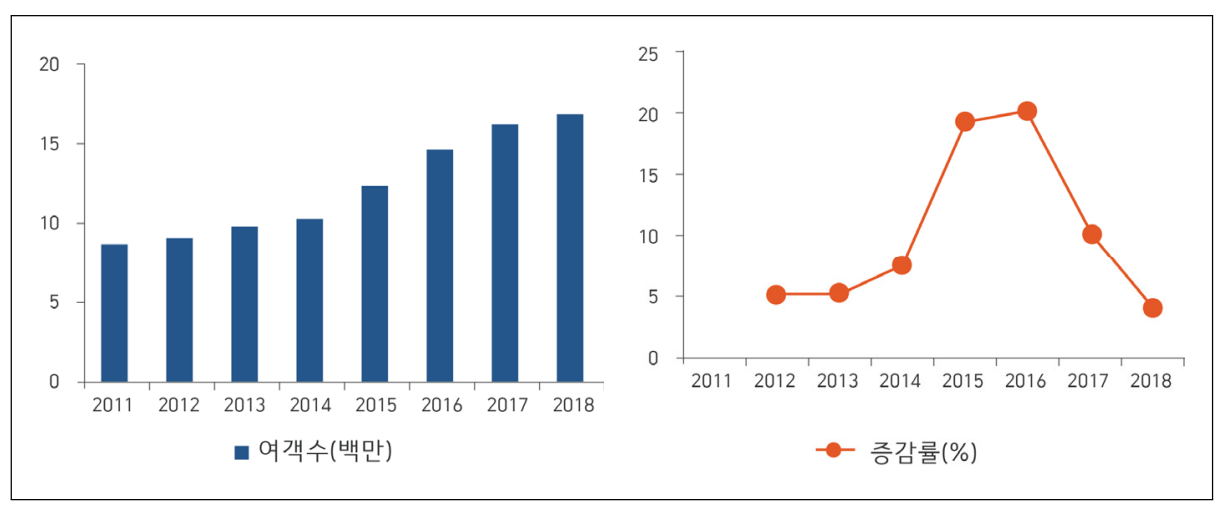

국토교통부의 항공교통서비스 보고서에 따르면, 2019년 김해공항의 국제선 항공 교통이용자는 전년대비 약 $2.8 \%$ 감소하였으며, 가장 많이 이용한 노선은 아시아, 일본, 중국, 대양주 노선 순으로 나타났다. 김해공항에서 가장 많이 증가한 노선은 
유럽(러시아) 노선으로 전년대비 약 $80.6 \%$ 증가하였으며, 다음은 아시아 노선으로 전년대비 약 $10.5 \%$ 증가를 보였다.

- 일본은 전년대비 $22.9 \%$ 로 큰 폭으로 감소를 보였음

- 국제선 노선별 점유율은 아시아 노선 약 $49.5 \%$, 일본 노선 약 $29.7 \%$ 차지

〈표 2-11〉 김해국제공항 노선별 항공여객 실적

\begin{tabular}{|c|c|c|c|c|c|c|c|}
\hline 구 분 & 2015 & 2016 & 2017 & 2018 & 2019 & $\begin{array}{c}\text { 전년대비 } \\
\text { 증감률 }\end{array}$ & 노선비율 \\
\hline 일본 & 2,107 & 2,864 & 3,382 & 3,693 & 2,848 & $-22.9 \%$ & $29.7 \%$ \\
\hline 중국 & 1,267 & 1,452 & 1,142 & 1,327 & 1,386 & $4.4 \%$ & $14.5 \%$ \\
\hline 아시아 & 2,410 & 3,157 & 3,838 & 4,296 & 4,747 & $10.5 \%$ & $49.5 \%$ \\
\hline 유럽 & 28 & 42 & 53 & 98 & 177 & $80.6 \%$ & $1.8 \%$ \\
\hline 대양주 & 145 & 262 & 399 & 452 & 433 & $-4.2 \%$ & $4.5 \%$ \\
\hline 합계 & 5,985 & 7,777 & 8,813 & 9,867 & 9,591 & $-2.8 \%$ & $100.0 \%$ \\
\hline
\end{tabular}

주1) 국제선(출발+도착), 전체여객(유임+무임+환승), 운항구분(정기+부정기)

2) 운송실적은 1,000 명 단위에서 반올림, 전년대비 증감률 및 연평균 증가율은 1 명 단위로 계산

출처: 국토교통부, 2019년 항공교통서비스 보고서

2019년 기준 김해공항의 국제노선 취항도시 현황을 살펴보면, 일본노선(12개 도 시)이 연간 운항 21,017 편, 여객 284만 명으로 가장 높게 나타났다. 그 다음으로 김해공항에서는 중국의 14 개 도시를 연결하는 국제노선이 운항 중이며 연간 운항 10,220 편, 여객 138 만 명으로 일본노선의 운항 편수 및 여객 수 규모의 절반 수준 에 해당한다.

동남아의 베트남은 나트랑, 다낭, 하노이, 호치민 4개 도시에 취항하고 있으며 연 간 운항 8,546 편, 여객 144 만 명으로 중국보다 다소 많다. 또한, 김해공항에서는 대만의 4개 도시와 연결하는 국제노선을 운항 중이며 연간 운항 6,109편 여객 94 만 명으로 집계되었다.

2019년 기준 김해공항의 국제노선 항공사별 통계를 살펴보면, 에어부산이 연간 총 17,660 편으로 가장 많았고 그 다음으로 대한항공(9,675편), 제주항공(8,235편), 진에어(5,819편), 아시아나항공(2,767편) 순으로 나타났다. 
〈표 2-12〉 김해공항 국제노선 취항도시 현황(2019년 기준)

\begin{tabular}{|c|c|c|c|c|}
\hline 구분 & 국가 & 도시 & 운항(편수) & 여객(명) \\
\hline \multirow{3}{*}{ 동북아 } & 중국 & $\begin{array}{c}\text { 광저우, 장자제, 하이코우, 항저우, 난징, } \\
\text { 베이징, 상하이, 선양, 스자좡, 산야, 칭다오, } \\
\text { 시안, 옌지, 옌타이 }\end{array}$ & 10,220 & $1,385,717$ \\
\hline & 일본 & $\begin{array}{c}\text { 삿포로, 시즈오카, 후쿠오카, 도쿄, 사가, } \\
\text { 오사카, 키타큐슈, 카고시마, 나고야, 오이다, } \\
\text { 오키나와, 도야마 }\end{array}$ & 21,017 & $2,847,832$ \\
\hline & 몽골 & 울란바토르 & 522 & 64,729 \\
\hline \multirow{10}{*}{ 동남아 } & 대만 & 화리엔, 가오슝, 타이페이, 타이쭝 & 6,109 & 940,527 \\
\hline & 홍콩 & 홍콩 & 1,801 & 270,566 \\
\hline & 마카오 & 마카오 & 727 & 108,848 \\
\hline & 태국 & 방콕 & 3,381 & 632,258 \\
\hline & 필리핀 & 세부, 클라크필드, 칼리보, 마닐라 & 4,357 & 706,394 \\
\hline & 베트남 & 나트랑, 다낭, 하노이, 호치민 & 8,546 & $1,447,015$ \\
\hline & 말레이시아 & 코타키나발루, 쿠알라룸푸르 & 1,807 & 358,598 \\
\hline & 싱가포르 & 싱가폴 & 524 & 83,761 \\
\hline & 캄보디아 & 씨엠립 & 337 & 51,569 \\
\hline & 라오스 & 비엔티안 & 570 & 81,932 \\
\hline \multirow{3}{*}{ 기타 } & 미국 & 괌, 사이판 & 2,763 & 433,489 \\
\hline & 브루나이 & 반다르세리 & 4 & 464 \\
\hline & 러시아 & 블라디보스토크 & 1,476 & 176,851 \\
\hline \multicolumn{3}{|r|}{ 합계 } & 64,161 & $9,590,550$ \\
\hline
\end{tabular}

자료: 한국공항공사 항공통계, 연구자 재정리

〈표 2-13〉 김해공항 국제노선 항공사별 통계(2019년 기준)

\begin{tabular}{c|c|c|c|c|c|c}
\hline \multirow{2}{*}{ 구분 } & \multicolumn{3}{|c|}{ 운항(편수) } & \multicolumn{3}{c}{ 여객(명) } \\
\cline { 2 - 7 } & 도착 & 출발 & 계 & 도착 & 출발 & 계 \\
\hline 대한항공 & 4,827 & 4,848 & 9,675 & 588,538 & 582,592 & $1,171,130$ \\
\hline 아시아나항공 & 1,375 & 1,392 & 2,767 & 165,583 & 164,184 & 329,767 \\
\hline 진에어 & 2,907 & 2,912 & 5,819 & 435,398 & 419,917 & 855,315 \\
\hline 에어부산 & 8,823 & 8,837 & 17,660 & $1,406,558$ & $1,406,943$ & $2,813,501$ \\
\hline 제주항공 & 4,112 & 4,123 & 8,235 & 650,919 & 646,103 & $1,297,022$ \\
\hline 기타 외항사 & 9,999 & 10,006 & 20,005 & $1,566,041$ & $1,557,774$ & $3,123,815$ \\
\hline 합계 & 32,043 & 32,118 & 64,161 & $4,813,037$ & $4,777,513$ & $9,590,550$ \\
\hline
\end{tabular}

자료: 한국공항공사 항공통계, 연구자 재정리 
방한 외국인 관광객들이 김해국제공항을 통해 출입국시 필요한 절차 및 과정은 이동 동선 거리가 짧아 평균 소요시간이 1 시간 이내로 파악되었다.

- 항공기 착륙 후 여권 및 비자 심사, 수하물 찾기, 세관 심사, 검역 등 김해공항 국제선 터미널 내 입국장 출구 정면에는 한국공항공사에서 운영 중인 공항안내데스크와 부산광역시, 경상남도, 경상북도(경주시)에서 운영하는 관광안내 데스크가 설치 운영되고 있다.

- 안내인력 상주, 해당 지자체의 외국어 관광안내지도 및 홍보물 비치 최근 한국공항공사에서는 항공여객을 위한 정보 안내 키오스크를 설치하였는데, 공항시설 안내와 연계교통 안내에 비하여 부산시 및 주변지역의 관광지와 여행에 관한 안내 정보는 개선이 필요한 것으로 조사되었다.

- 주요 관광지 정보의 경우, 외국어(영어) 자료와 콘텐츠가 매우 미흡함 김해공항 국제선 터미널 입국층에는 여행사 미팅, 와이파이 대여, 휴대폰 로밍, 유심 판매, 렌트카 대여, 카지노·국제행사 홍보 카운터가 입점하여 있다. 또한 김해 공항 국제선 터미널 출국장 내에는 외국인 관광객들의 쇼핑을 위한 공항면세점과 면세품인도장, 세금환급(Tax-refund) 부스가 운영 중이다.

김해공항 내에는 국제선 터미널과 국내선 터미널을 순환하는 무료 셔틀버스가 운 행 중이며, 공항 리무진 버스는 해운대와 부산역 등을 연결하고 있다. 그 외 대중교 통 수단으로는 경전철, 택시, 시외버스 등이 이용 가능하다.

〈표 2-14〉김해공항 접근 교통수단

\begin{tabular}{|c|c|c|c|}
\hline 구분 & & & 세부내용 \\
\hline \multirow{6}{*}{ 버스 } & 공항내 & 셔틀버스 & 국제선-국내선-P3주차장 \\
\hline & \multirow{4}{*}{ 시내 } & 리무진 & 해운대 방향, 서면/부산역 방향 \\
\hline & & 일반버스 & 해운대구청 \\
\hline & & 급행간선 & 금곡/가덕선착장 \\
\hline & & 마을버스 & 신평마을, 구포시장 / 하단, 덕천로터리 \\
\hline & 시외 & 시외버스 & $\begin{array}{l}\text { 거제, 경주, 포항, 광양, 대전(구미), 동대구, 울산, 장유, 진주, } \\
\text { 진해, 창원/마산, 통영 }\end{array}$ \\
\hline 지하철 & \multicolumn{3}{|c|}{ 부산-김해 경전철 } \\
\hline
\end{tabular}


[사진 2-1] 김해공항 관광편의시설 현황

김해공항 및 부산시 안내데스크

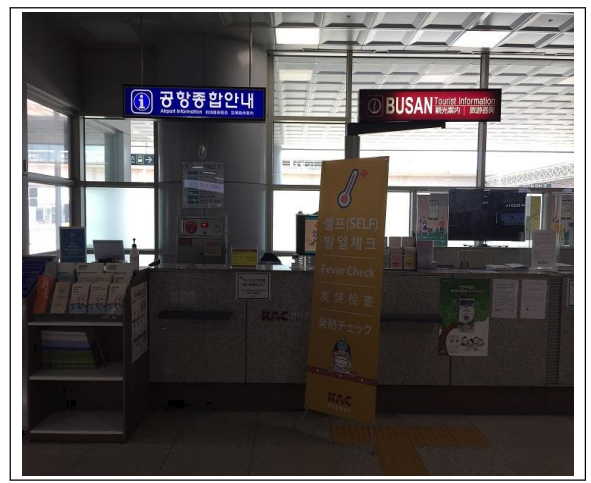

키오스크 관광안내정보 사례

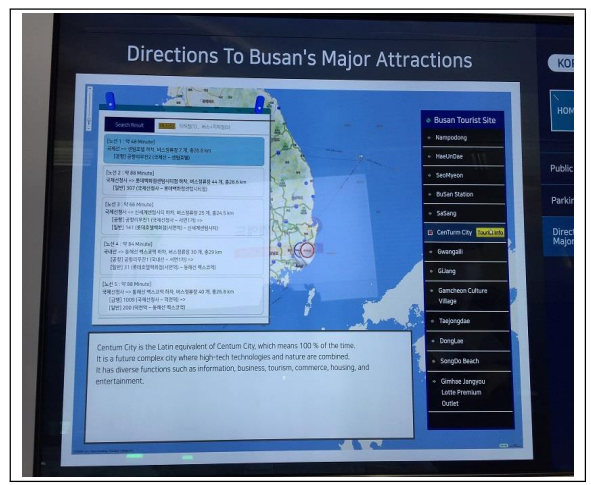

외국어(영어) 안내 키오스크

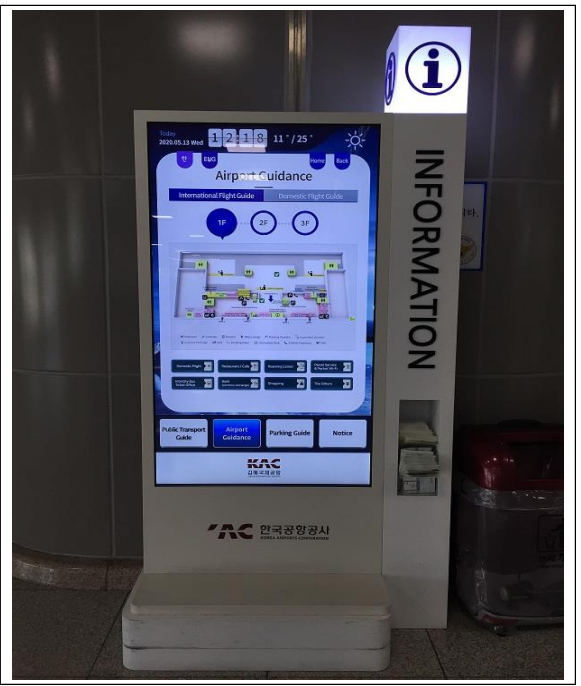

경상남도 및 경주시 안내데스크

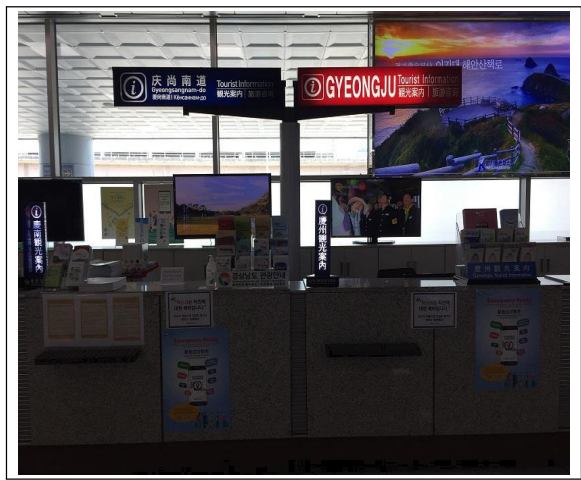

김해공항 출국장 내 면세점

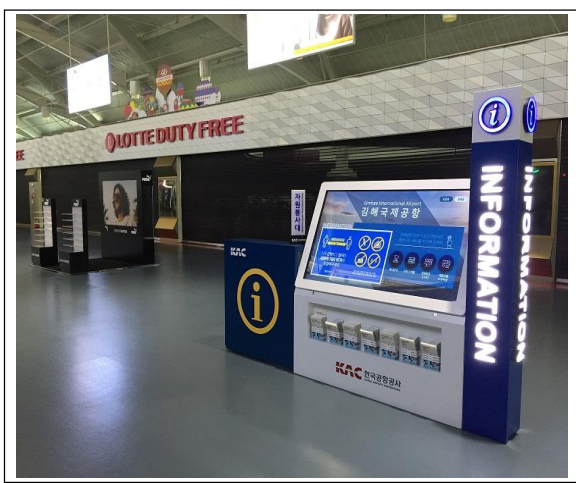

국제선 터미널 대중교통 안내

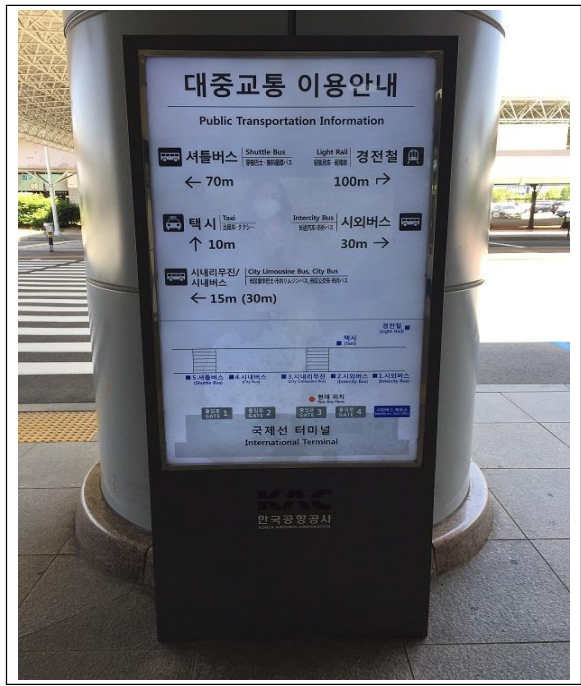




\section{2. 무안국제공항}

무안국제공항(MWX/RKJB)은 전라남도 무안군 망운면에 위치하며, 두 개 활주로 와 항공기 48대 동시주기능력을 갖춘 계류장을 보유하고 있다. 무안국제공항 내 국 제여객터미널은 연간 94만 명의 항공 여객 수용이 가능하며, 동시에 1,871 대가 주 차할 수 있는 면적의 공간을 갖추고 있다.

〈표 2-15〉 무안국제공항의 주요시설 현황

\begin{tabular}{c|c|c|c|c|c|c}
\hline 활주로 & \multicolumn{2}{|c|}{ 국제여객터미널 } & \multicolumn{2}{|c|}{ 계류장 } & \multicolumn{2}{|c}{ 주차장 } \\
\hline $\begin{array}{c}\text { Runways } \\
(\mathrm{m})\end{array}$ & $\begin{array}{c}\text { 면적 } \\
\left(\mathrm{m}^{2}\right)\end{array}$ & $\begin{array}{c}\text { 수용능력 } \\
(\text { 만 명/년) }\end{array}$ & $\begin{array}{c}\text { 면적 } \\
\left(\mathrm{m}^{2}\right)\end{array}$ & $\begin{array}{c}\text { 동시주기능력 } \\
(\text { 대})\end{array}$ & $\begin{array}{c}\text { 면적 } \\
\left(\mathrm{m}^{2}\right)\end{array}$ & $\begin{array}{c}\text { 동시주차능력 } \\
(\text { 대 })\end{array}$ \\
\hline $\begin{array}{c}3,750 \times 60 \\
3,750 \times 60\end{array}$ & 9,106 & 94 & 90,692 & $\begin{array}{c}48 \\
(\text { 일반4,소형44) }\end{array}$ & 66,990 & 1,871 \\
\hline
\end{tabular}

자료: 항공정보포털시스템, 2019년 12월 기준

무안국제공항의 연간 운항횟수 실적을 보면 기존에 비해 2015년에 높은 실적을 보인 후 다소 주춤하다가 2018년에 다시 큰 폭으로 증가하였다.

〈표 2-16〉 무안국제공항 연도별 운항횟수

(단위: 회)

\begin{tabular}{c|c|c|c|c|c|c|c}
\hline 2011년 & 2012년 & 2013년 & 2014년 & 2015년 & 2016년 & 2017년 & 2018년 \\
\hline 875 & 923 & 1,237 & 1,499 & 2,355 & 2,330 & 2,146 & 3,818 \\
\hline
\end{tabular}

[그림 2-19] 무안국제공항 연간 운항횟수 추이

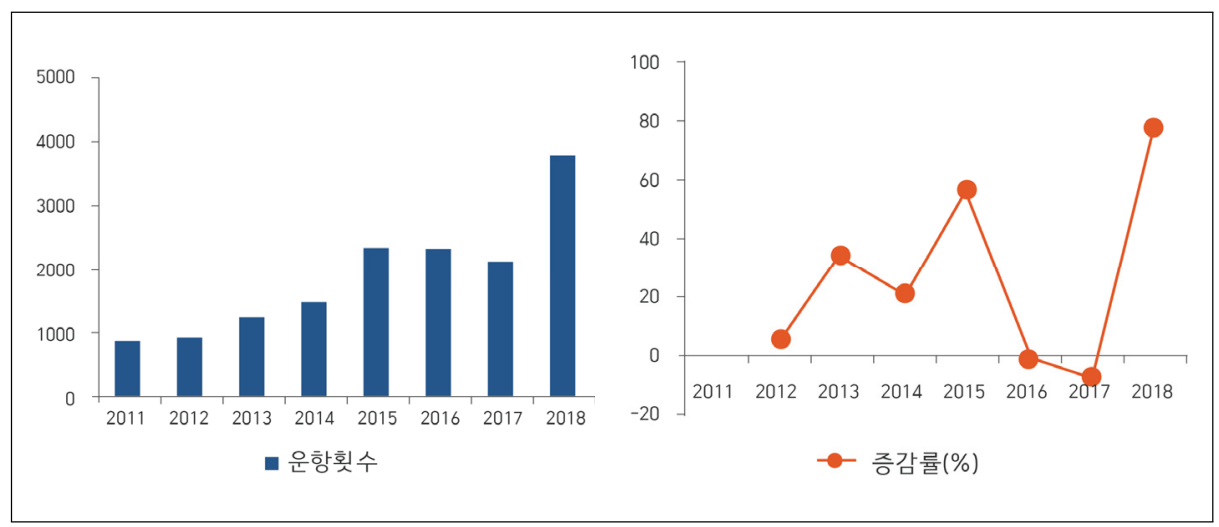


무안국제공항의 연간 여객실적 역시 꾸준하게 증가 추세를 보이고 있으며, 특히 2015년과 2018년에 빠른 성장을 기록하였다.

〈표 2-17〉 무안국제공항 연도별 여객실적

(단위: 명)

\begin{tabular}{c|c|c|c|c|c|c|c}
\hline 2011년 & 2012년 & 2013년 & 2014년 & 2015년 & 2016년 & 2017년 & 2018년 \\
\hline 91,133 & 96,166 & 132,603 & 178,414 & 311,922 & 321,675 & 298,016 & 543,247 \\
\hline
\end{tabular}

[그림 2-20] 무안국제공항 연간 여객실적 추이

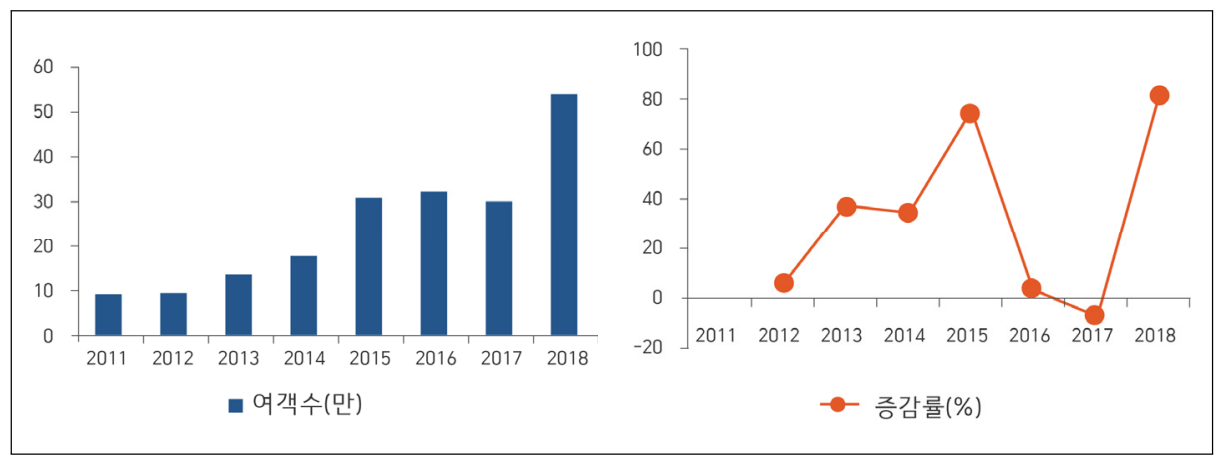

국토교통부의 항공교통서비스 보고서에 따르면, 2019년 무안국제공항의 국제선 항공교통이용자는 전년대비 약 $110.5 \%$ 증가하였다. 무안국제공항에서 가장 많이 이용한 노선은 아시아, 일본 순이며 전년대비 가장 많이 증가한 노선은 아시아 노선 으로 전년대비 약 $136.9 \%$ 증가를 보였다.

〈표 2-18〉 무안국제공항 노선별 항공여객 실적

(단위: 천명, \%)

\begin{tabular}{c|c|c|c|c|c|c|c}
\hline 구분 & 2015 & 2016 & 2017 & 2018 & 2019 & 전년대비 증감률 & 노선비율 \\
\hline 일본 & 9 & 13 & 48 & 98 & 156 & $58.7 \%$ & $22.7 \%$ \\
\hline 중국 & 151 & 157 & 32 & 20 & 38 & $96.4 \%$ & $5.6 \%$ \\
\hline 아시아 & 24 & 26 & 76 & 199 & 471 & $136.9 \%$ & $68.5 \%$ \\
\hline 유럽 & - & - & 1 & 10 & 20 & $105.1 \%$ & $2.9 \%$ \\
\hline 대양주 & - & - & - & 0 & 2 & - & $0.3 \%$ \\
\hline 합계 & 183 & 195 & 157 & 327 & 687 & $110.5 \%$ & $100.0 \%$ \\
\hline
\end{tabular}

주1) 국제선(출발+도착), 전체 여객(유임+무임+환승), 운항구분(정기+부정기)

2) 운송실적은 1,000 명 단위에서 반올림, 전년대비 증감률 및 연평균 증가율은 1 명 단위로 계산

자료: 국토교통부, 2019년 항공교통서비스 보고서 
2019년 기준 무안공항의 국제노선 취항도시 현황을 보면 일본노선(6개 도시)이 연간 운항 1,425 편, 여객 15 만 명으로 가장 높게 나타났다. 그 다음으로 베트남의 5 개 도시를 연결하는 국제노선이 운항 중이며 연간 운항 1,069 편, 여객 16 만 명으 로 일본노선보다 여객 수가 많았다.

대만은 타이페이 1 개 도시만 취항하고 있는데 연간 운항 714 편, 여객 10 만 명으 로 집계되었다. 또한 필리핀의 3개 도시를 연결하는 국제노선이 운항되었으며, 태 국노선은 방콕 1 개 도시만 취항한 것으로 나타났다.

중국은 장자제, 상하이, 산야, 타이유안, 옌지 등 5개 도시에 취항중이나 연간 운 항 321편, 여객 약 4만 명 수준에 그치고 있다. 한편, 홍콩은 작년 기준 무안공항에 서는 국제노선이 전혀 운항되지 않았다.

〈표 2-19〉 무안공항 국제노선 취항도시 현황(2019년 기준)

\begin{tabular}{|c|c|c|c|c|}
\hline 구분 & 국가 & 도시 & 운항(횟수) & 여객(명) \\
\hline \multirow{3}{*}{ 동북아 } & 중국 & $\begin{array}{c}\text { 장자제, 상하이, 산야, 타이유안, } \\
\text { 옌지 }\end{array}$ & 321 & 38,261 \\
\hline & 일본 & $\begin{array}{l}\text { 삿포로, 후쿠오카, 오사카, } \\
\text { 키타큐슈, 도쿄, 오이다 }\end{array}$ & 1,425 & 156,234 \\
\hline & 몽골 & 울란바토르 & 89 & 9,009 \\
\hline \multirow{9}{*}{ 동남아 } & 대만 & 타이페이 & 714 & 102,859 \\
\hline & 마카오 & 마카오 & 146 & 17,563 \\
\hline & 태국 & 방콕 & 426 & 63,693 \\
\hline & 필리핀 & 세부, 클라크필드, 칼리보 & 561 & 79,029 \\
\hline & 베트남 & 나트랑, 다낭, 달랏, 하노이, 호치민 & 1,069 & 165,090 \\
\hline & 말레이시아 & 코타키나발루 & 237 & 31,076 \\
\hline & 싱가포르 & 싱가폴 & 1 & 72 \\
\hline & 캄보디아 & 씨엠립 & 8 & 1,226 \\
\hline & 라오스 & 비엔티안 & 8 & 1,113 \\
\hline \multirow{2}{*}{ 기타 } & 미국 & 괌 & 14 & 1,932 \\
\hline & 러시아 & 블라디보스토크 & 176 & 20,123 \\
\hline \multicolumn{3}{|c|}{ 합계 } & 5,195 & 687,280 \\
\hline
\end{tabular}

자료: 한국공항공사 항공통계, 연구자 재정리

2019년 기준 무안공항의 국제노선 항공사별 통계를 살펴보면, 제주항공이 연간 총 3,997 편으로 가장 많은 반면 대한항공은 단 1 편에 불과했다. 
〈표 2-20〉무안공항 국제노선 항공사별 통계(2019년 기준)

\begin{tabular}{c|c|c|c|c|c|c}
\hline \multirow{2}{*}{ 구분 } & \multicolumn{3}{|c|}{ 운항(편수) } & \multicolumn{3}{c}{ 여객(명) } \\
\cline { 2 - 7 } & 도착 & 출발 & 계 & 도착 & 출발 & 계 \\
\hline 대한항공 & 1 & 0 & 1 & 72 & 0 & 72 \\
\hline 제주항공 & 1,998 & 1,999 & 3,997 & 269,733 & 272,635 & 542,368 \\
\hline 기타 외항사 & 596 & 601 & 1,197 & 72,051 & 72,789 & 144,840 \\
\hline 합계 & 2,595 & 2,600 & 5,195 & 341,856 & 345,424 & 687,280 \\
\hline
\end{tabular}

자료: 한국공항공사 항공통계, 연구자 재정리

방한 외국인 관광객이 무안국제공항을 통해 출입국시 필요한 절차 및 과정은 이 동 동선 거리가 짧아 평균 소요시간이 1 시간 이내로 파악되었다. 무안공항 국제선 터미널 내 입국장 전면에는 전라남도 관광안내소가 운영되고 있으며, 전라도 지역 통합안내 관광홍보물과 광주시, 목포시, 순천시 등 인근 도시를 홍보하는 터치스크 린과 광고판 등이 설치되어 있다.

무안공항 국제선 터미널 출국장 내에는 외국인 관광객의 쇼핑을 위한 소규모 공 항면세점과 면세품인도장이 입점하고 있다. 무안공항에 접근시 이용 가능한 대중교 통으로는 공항과 무안터미널을 연결하는 군내버스와 광주시, 목포시 등 주변 도시 를 연결하는 군외버스와 택시 등이 있다.

[사진 2-2] 무안공항 관광편의시설 현황

전라남도 관광안내소

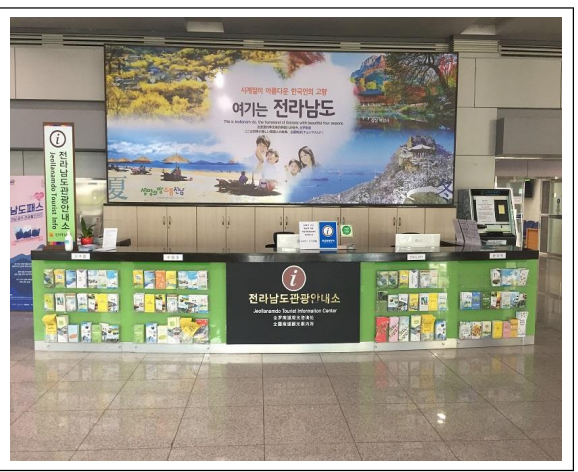

공항 내 면세점

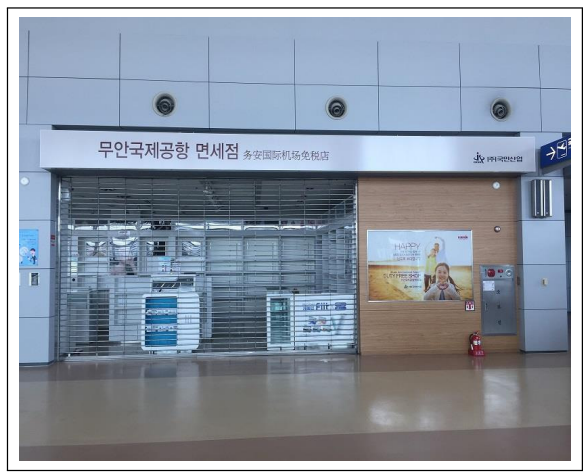




\section{제4절 분석결과 및 시사점}

\section{가. 지방공항의 입국 관문 역할과 기능 미흡}

전체 방한 외래관광객의 약 $90 \%$ 가 공항을 통해 입국하고 있으며, 여러 교통수단 가운데 항공이 차지하는 비율은 최근 증가 추세를 보이고 있다. 이처럼 국제관광에 있어서 항공교통의 중요성이 점점 커지고 있으나, 국토교통부의 인천공항 허브화 전략은 방한 외래관광객들의 서울 수도권 방문 집중을 심화시킬 우려가 있다. 실제 로 방한 외국인 관광객이 인천공항을 통해 입국한 비율이 약 $70 \%$ 에 이르고 있으며, 김해공항과 제주공항 등 일부 공항을 제외한 국내 지방공항은 입국 관문으로서 역 할과 기능이 미미한 실정이다.

\section{나. 주요 방한시장별 지방공항 이용 패턴 차이}

주요 방한 인바운드 시장 가운데 중국시장은 제주공항을 통해 입국한 비율이 다 른 국가에 비해 상대적으로 높고, 일본시장은 김포공항과 김해공항을 자주 이용하 는 것으로 나타났다. 장거리 시장인 미국과 동남아 지역의 홍콩, 베트남, 태국은 입 국 시 인천공항을 이용한 비율이 높게 나타나 지방공항의 적극적인 유치 노력이 요 청된다. 특히, 중국과 동남아 시장의 경우 무비자 제도 시행 여부가 국내 지방공항 이용에 영향을 미친 것으로 추측된다.

\section{다. 국제여객노선 운항 실적 인천공항에 집중}

한국공항공사의 항공통계에 따르면, 우리나라 전체 국제여객노선 운항 실적은 2015년 35만 편에서 2019년 49만 편으로 증가하였으며, 공항별로 살펴보면 인천 공항이 약 $74 \%$ 로 압도적으로 높고 김해공항, 김포공항, 대구공항, 제주공항의 순으 
로 나타났다. 국제여객노선 여객(내국인 포함) 실적 역시 2015년 6,183만 명에서 2019년 9,090만 명으로 성장하였으며, 인천공항에 이어 김해공항, 김포공항, 제주 공항, 대구공항 등 순으로 나타났다. 또한 우리나라 환승(통과)여객 대다수가 인천 공항에 집중되고 있는 것으로 분석된다.

\section{라. 아웃바운드 수요 중심의 국제노선 운항}

본 연구의 주요 대상인 김해공항과 무안공항의 국제여객노선 운항 현황을 살펴보 면, 지금까지는 우리 국민의 해외여행 아웃바운드 수요와 선호 목적지를 중심으로 직항노선과 운항편수가 배분되어 온 경향이 많았다. 그러나 향후에는 방한 인바운 드 유치 확대를 위해 중요한 전략시장을 우선적으로 고려하고, 취항도시의 경우 지 방의 소규모 휴양도시보다는 관광송출 잠재력이 높은 대도시를 선정할 필요가 있 다. 김해공항과 무안공항 국제노선 항공사별 통계를 보면 국내 LCC업계 비중이 각 각 $49.4 \%, 76.9 \%$ 로 높게 나타나 지방공항의 활성화를 위해서는 LCC 유치 필요성 이 높은 것으로 분석된다.

\section{마. 지방공항의 안내 및 연계교통 개선 필요}

김해공항과 무안공항은 기본적인 관광편의시설과 서비스를 갖추고 있으나, 외국 어 통역 지원 및 관광안내 정보 서비스 등 개선이 요구된다. 또한 공항에서 배후 도심이나 주요 관광지까지 연결하는 대중교통 서비스가 부족한 경우가 많아 지방공 항을 이용하는 외국인 관광객의 불편이 예상된다. 국내 지방공항의 접근성 개선을 위해서는 KTX, 도시철도, 고속도로 등과 연계를 강화하고 개별여행자를 위한 렌트 카, 공유차량 서비스를 확충할 필요가 있다. 

지방공항을 활용한 지역관광 활성화 방안

제3장

조사 데이터 분석 



\section{제1절 항공여객 $\mathrm{OD}$ 조사 데이터 심층 분석}

\section{1. 조사개요 및 분석방법}

당초 본 연구에서는 국내 지역을 관광한 후 지방공항을 통해 출국하는 외국인 관 광객을 대상으로 직접 설문조사를 실시할 계획이었으나, 코로나19의 확산 영향으로 불가피하게 대안을 강구하게 되었다. 우선, 첫 번째 대안으로 방한 외국인 관광객들 의 항공편 이동경로, 공항접근 교통수단 등 구체적인 여행 특성을 파악하고 지방공 항 이용 관련 주요 개선사항을 도출하기 위하여, 국토교통부 지원으로 한국항공협 회에서 주관한 「2019 항공여객 OD 및 특성조사2)」의 데이터를 연구목적에 맞게 재분석하였다.

- 분석 대상 : 김해공항, 무안공항 이용 외국인 관광객

- 분석 데이터 수 : 총 700명(김해공항 592명, 무안공항 108명)

- 데이터 수집 기간 : 2019년 6월 2019년 10월

- 조사 횟수 : 조사기간 내 총 4회 실시(비수기 3회, 성수기 1회)

〈표 3-1〉 조사 횟수

\begin{tabular}{c|c|c}
\hline 차수 & 조사 일정 & 특성구분 \\
\hline 1차 조사 & $06.03 \sim 06.16$ (14일 간) & 비수기 \\
\hline 2차 조사 & $07.22 \sim 08.04$ (14일 간) & 성수기 \\
\hline 3차 조사 & $09.16 \sim 09.29$ (14일 간) & 비수기 \\
\hline 4차 조사 & $10.14 \sim 10.27$ (14일 간) & 비수기 \\
\hline
\end{tabular}

자료: 한국항공협회(2020), 「2019 항공여객 OD 및 특성조사」보고서.

「2019 항공여객 OD 및 특성조사」의 전체 설문 구조와 내용은 〈표 3-2〉와 같으 며, 본 연구에서 심층 분석한 조사 항목은 〈표 3-3〉과 같다.

2) 국토교통부 지원으로 한국항공협회에서 주관하였으며 본 연구목적을 위해 조사 원자료를 제공함. 
〈표 3-2〉 조사 설문 구조 및 내용

\begin{tabular}{|c|c|c|}
\hline 평가 항목 & \multicolumn{2}{|c|}{ 세부 항목 } \\
\hline 응답자 선정 및 구분 & $\begin{array}{l}\text { - 응답자 구분 } \\
\text { - 국적 } \\
\text { - 성/연령 }\end{array}$ & $\begin{array}{l}\text { - 비행편명 } \\
\text { - 도착 공항 및 도착 국가 } \\
\text { - 자가용 보유 여부 }\end{array}$ \\
\hline 방한 행태 & $\begin{array}{l}\text { - 한국만 방문 또는 } \\
\text { 타 국가 병행 방문 여부 }\end{array}$ & - 환승객 여부 \\
\hline 환승행태 및 이동 경로 & $\begin{array}{l}\text { - 환승 종류 } \\
\text { - 환승 선택 이유 }\end{array}$ & $\begin{array}{l}\text { - 해외 출발 공항/ } \\
\text { 이용 항공편 }\end{array}$ \\
\hline $\begin{array}{l}\text { 이전 출발지에서 } \\
\text { 국내 유입 경로 }\end{array}$ & $\begin{array}{l}\text { - 국내 입국 공항 } \\
\text { - 입국 시 환승 여부 }\end{array}$ & $\begin{array}{l}\text { - 출발지 공항/ 이용 항공편 } \\
\text { - (환승시) 환승 공항/ } \\
\text { 이용 항공편/ 환승 이유 }\end{array}$ \\
\hline 국내 이동 경로 & $\begin{array}{l}\text { - 국내 방문 장소 } \\
\text { - 국내 방문 교통수단 }\end{array}$ & $\begin{array}{l}\text { - 교통수단별 이용 만족도 } \\
\text { 및 불만족 사유 }\end{array}$ \\
\hline $\begin{array}{l}\text { 현재 공항도착까지 } \\
\text { 이동 경로 파악 }\end{array}$ & $\begin{array}{l}\text { - 공항으로의 출발 지역 } \\
\text { - 공항 도착 이용 교통수단 } \\
\text { - 교통수단별 소요시간/ 이용 구간/ } \\
\text { 이용 이유 }\end{array}$ & $\begin{array}{l}\text { - 교통수단별 이용 만족도 } \\
\quad \text { 및 불만족 사유 } \\
\text { - 비행기 출발 전 도착 시간 }\end{array}$ \\
\hline $\begin{array}{l}\text { 현재 공항에서 최종 목적지 } \\
\text { 까지 이동 경로 }\end{array}$ & $\begin{array}{l}\text { - 다음 공항에서의 환승 여부 } \\
\text { - 환승 후 최종 목적지 공항/ 이용 항공편 } \\
\text { - 환승 선택 이유 }\end{array}$ & - 최종목적지 도시명 \\
\hline 항공 여객 이용 행태 & $\begin{array}{l}\text { - 여행 목적, 동반자, 일수 } \\
\text { - 여행 형태 }\end{array}$ & $\begin{array}{l}\text { - 한국 방문 횟수 } \\
\text { - 항공권 구매 장소 } \\
\text { - 항공권 체크인 방법 }\end{array}$ \\
\hline
\end{tabular}

〈표 3-3〉 심층 분석 조사 항목

\begin{tabular}{|c|c|}
\hline 구분 & 조사 항목 \\
\hline 방한 여행 행태 & $\begin{array}{l}\text { - 방한 횟수, 타 국가 병행 방문 여부 } \\
\text { - 여행 형태, 여행 동반자 형태 } \\
\text { - 방한 목적, 여행 일수, 항공권 구매 경로 } \\
\text { - 국내 방문 지역, 지역 방문시 이용 교통수단 } \\
\text { - 교통수단 만족도 }\end{array}$ \\
\hline 공항까지의 이동경로 & $\begin{array}{l}\text { - 공항으로의 출발 지역, 공항접근 교통수단 } \\
\text { - 교통수단 선택이유, 교통수단별 소요시간 } \\
\text { - 교통수단별 만족도 및 불만족 이유 } \\
\text { - 비행기 출발전 도착시간 }\end{array}$ \\
\hline 항공편 이동경로 & $\begin{array}{l}\text { - 입국 전 출발 국가, 입국 시 이용 공항 } \\
\text { - 출국 후 도착 국가, 도착 공항에서의 환승 현황 } \\
\text { - 최종 목적지 국가 }\end{array}$ \\
\hline 환승 행태 & $\begin{array}{l}\text { - 환승 여부, 환승 유형 } \\
\text { - 환승 공항 선택이유 }\end{array}$ \\
\hline
\end{tabular}


본 조사 결과에 대한 해석 및 분석 시 다음과 같은 사항에 유의할 필요가 있다.

- 기존의 「2019 항공여객 OD 및 특성조사」데이터를 응답자의 특성에 따라 교 차분석을 하였으나, 통계적으로 의미를 부여하는 표본수 30명에 못 미치는 분 석은 해석에 유의해야 함

- 각 통계표 내 비율은 소수점 둘째자리에서 반올림하였으므로 세목과 그 총계 가 일치하지 않는 경우가 있으며, 표기된 비율로 단순 합산할 경우 오차가 발 생할 수 있음

- 일부 설문 문항의 경우 복수로 응답된 문항이 있으므로 그 합계는 $100 \%$ 가 넘을 수도 있음

- 일부 척도 문항에 대한 100 점 점수 변환은 아래 계산식을 따름

〈표 3-4〉 척도 문항에 대한 100점 점수 변환

\begin{tabular}{|c|c|c|c|c|c|}
\hline 척도 & (1) & (2) & (3) & (4) & (5) \\
\hline \multicolumn{1}{|c|}{ 척도 의미 } & $\boldsymbol{\nabla}$ & $\boldsymbol{\nabla}$ & $\boldsymbol{\nabla}$ & $\boldsymbol{\nabla}$ & $\boldsymbol{\nabla}$ \\
\hline & $\begin{array}{c}\text { 전혀 } \\
\text { 그렇지 않다 }\end{array}$ & 그렇지 않다 & 보통이다 & 그렇다 & 매우 그렇다 \\
\hline 100점 환산 & $\boldsymbol{\nabla}$ & $\boldsymbol{\nabla}$ & $\boldsymbol{\nabla}$ & $\boldsymbol{\nabla}$ & $\boldsymbol{\nabla}$ \\
\hline
\end{tabular}

- 척도 문항에 대해 (1), (2)의 비율을 합산하여 부정응답(Bottom2)으로, (3)의 비 율을 보통(Middle)으로, (4), (5)의 비율을 합산하여 긍정응답(Top2)으로 정의

〈표 3-5〉 부정응답, 보통, 긍정응답 정의

\begin{tabular}{|c|c|c|c|c|c|}
\hline 척도 문항 & $\begin{array}{l}\text { 전혀 } \\
\text { 그렇지 않다 } \\
\text { (1) }\end{array}$ & $\begin{array}{c}\text { 그렇지 않다 } \\
\text { (2) }\end{array}$ & $\begin{array}{c}\text { 보통이다 } \\
\text { (3) }\end{array}$ & $\begin{array}{l}\text { 그렇다 } \\
\text { (4) }\end{array}$ & $\begin{array}{c}\text { 매우 그렇다 } \\
\text { (5) }\end{array}$ \\
\hline & \multicolumn{2}{|l|}{$\nabla$} & $\nabla$ & \multicolumn{2}{|l|}{$\nabla$} \\
\hline 정의 & \multicolumn{2}{|c|}{$\begin{array}{c}\text { 부정응답 } \\
\text { (Bottom2, (1)+2) }\end{array}$} & $\begin{array}{c}\text { 보통 } \\
\text { (Middle, (3)) }\end{array}$ & \multicolumn{2}{|c|}{$\begin{array}{c}\text { 긍정응답 } \\
\text { (Top2, (4)+(5)) }\end{array}$} \\
\hline
\end{tabular}




\section{2. 김해공항 분석결과}

\section{가. 방한 여행 형태}

1) 응답자 특성

- 김해공항을 이용하는 외국인 관광객의 국적은 '일본'(34.1\%), '대만'(20.1\%), '중국'(13.3\%) 등의 순임

- 이용 항공사는 $\mathrm{LCC}(53.9 \%)$, 외항사(28.9\%), $\mathrm{FSC}(17.2 \%)$ 의 순임

- '개별여행'인 경우가 $88.9 \%$ 로 ‘패키지여행'(11.1\%) 보다 훨씬 많음

- 한국을 '재방문(2-4회)'(61.8\%)한 외국인 관광객이 '처음 방문'(22.8\%)하거나 '자주 방문(5회 이상)'(15.4\%)한 관광객보다 많음

\section{〈표 3-6〉 김해공항 응답자 특성}

Base: 김해공항 관광목적 외국인 이용객, $\mathrm{n}=592$, 단위: \%

\begin{tabular}{|c|c|c|c|}
\hline \multicolumn{2}{|c|}{ 구분 } & 사례수 & 구성비(\%) \\
\hline \multicolumn{2}{|c|}{ 전체 } & (592) & 100.0 \\
\hline \multirow{2}{*}{ 성별 } & 남성 & $(228)$ & 38.5 \\
\hline & 여성 & $(364)$ & 61.5 \\
\hline \multirow{6}{*}{ 연령별 } & 15세-20세 미만 & (24) & 4.1 \\
\hline & 20대 & (155) & 26.2 \\
\hline & 30대 & (149) & 25.2 \\
\hline & 40대 & $(123)$ & 20.8 \\
\hline & 50대 & (97) & 16.4 \\
\hline & 60대 이상 & (44) & 7.4 \\
\hline \multirow{2}{*}{ 여행 행태별 } & 개별 여행 & (526) & 88.9 \\
\hline & 패키지 여행 & (66) & 11.1 \\
\hline \multirow{2}{*}{ 여행 동반인별 } & 혼자 여행 & $(145)$ & 24.5 \\
\hline & 동반 여행 & $(447)$ & 75.5 \\
\hline \multirow{3}{*}{ 방한 빈도별 } & 처음 방문 & $(135)$ & 22.8 \\
\hline & 재방문(2-4회) & $(366)$ & 61.8 \\
\hline & 자주 방문(5회 이상) & (91) & 15.4 \\
\hline \multirow{3}{*}{ 이용 항공사별 } & FSC & $(102)$ & 17.2 \\
\hline & LCC & $(319)$ & 53.9 \\
\hline & 외항사 & $(171)$ & 28.9 \\
\hline
\end{tabular}




\begin{tabular}{|c|c|c|c|}
\hline \multicolumn{2}{|r|}{ 구분 } & 사례수 & 구성비(\%) \\
\hline \multirow{6}{*}{ 국적별 } & 중국 & (79) & 13.3 \\
\hline & 일본 & (202) & 34.1 \\
\hline & 미주 & (30) & 5.1 \\
\hline & 기타 아시아 & (205) & 34.6 \\
\hline & 유럽 & (64) & 10.8 \\
\hline & 대양주/아프리카/기타 & $(12)$ & 2.0 \\
\hline \multirow{18}{*}{ 세부 국적별 } & 중국 & (79) & 13.3 \\
\hline & 일본 & $(202)$ & 34.1 \\
\hline & 미국 & $(17)$ & 2.9 \\
\hline & 대만 & (119) & 20.1 \\
\hline & 홍콩 & (39) & 6.6 \\
\hline & 태국 & (7) & 1.2 \\
\hline & 필리핀 & (2) & 0.3 \\
\hline & 베트남 & (5) & 0.8 \\
\hline & 말레이시아 & $(17)$ & 2.9 \\
\hline & 러시아 & (17) & 2.9 \\
\hline & 싱가포르 & (8) & 1.4 \\
\hline & 인도네시아 & (1) & 0.2 \\
\hline & 기타 아시아 & (7) & 1.2 \\
\hline & 유럽 & (47) & 7.9 \\
\hline & 미국 외 미주/아메리카 & (13) & 2.2 \\
\hline & 오세아니아 & (9) & 1.5 \\
\hline & 아프리카 & (1) & 0.2 \\
\hline & 기타 & (2) & 0.3 \\
\hline
\end{tabular}

\section{2) 여행 목적}

- 여행 목적은 '여가/위락/개별휴가'(63.9\%), ‘친구, 친지 방문'(17.7\%), ‘쇼핑' (17.2\%), ‘미용, 건강 및 치료'(1.2\%) 순임

- 방한 횟수가 많은 관광객이 처음 방문하는 관광객보다 '친구, 친지 방문' 이나 ‘쇼핑'을 목적으로 오는 경우가 많음 


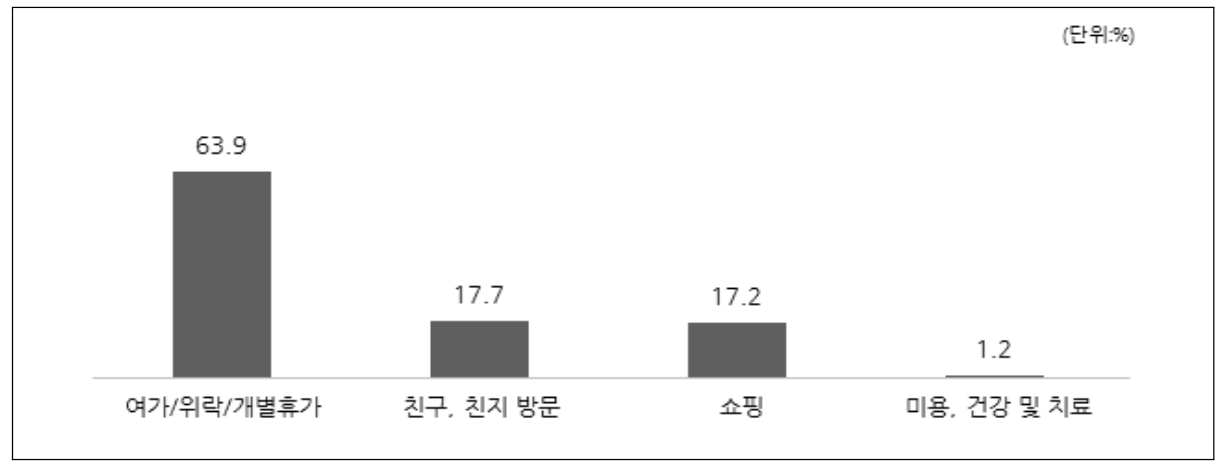

3) 여행 동반자 형태

- 여행 동반자는 '가족/친지'(35.3\%), '친구'(32.9\%), '혼자(동반인 없음)'(24.5\%) 등의 순임

- '일본'의 경우 다른 국적보다 '친구'(43.1\%)와 함께 여행하는 경우가 많음

[그림 3-2] 여행 동반자 형태_김해공항

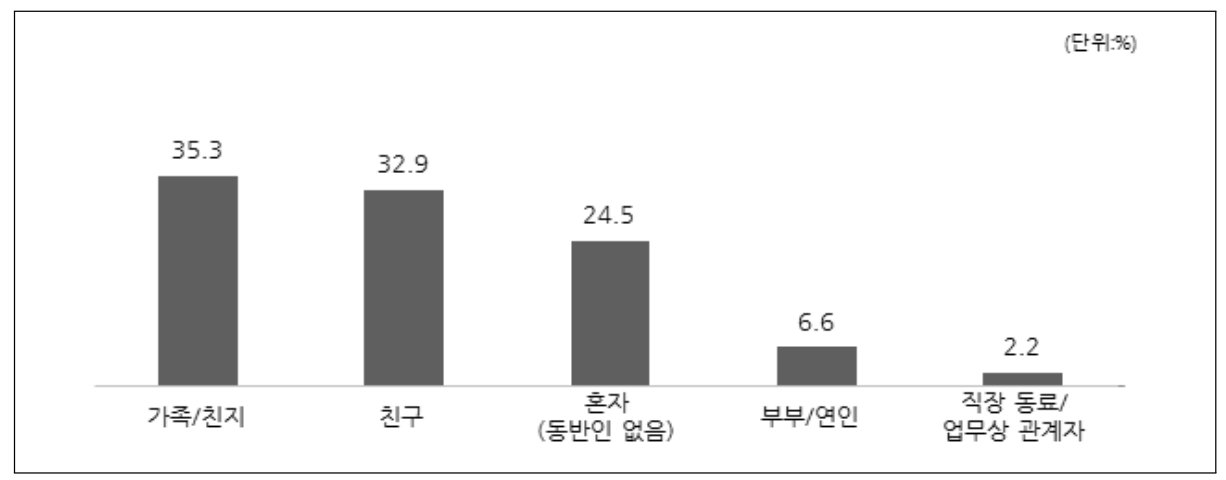

4) 여행 인원

- 여행 인원은 '2-4명'(57.1\%), '1명(혼자)'(24.5\%), ‘5명 이상'(18.4\%) 순임

- 가족/친지인 경우 평균 4.1명, 부부/연인인 경우 평균 2.9 명, 직장 동료/업무 상 관계자인 경우 평균 17 명, 친구인 경우는 평균 4.6명으로 나타남

- 김해공항을 이용하는 외국인 관광객의 여행 인원은 평균 3.6명임 
[그림 3-3] 여행 인원_김해공항

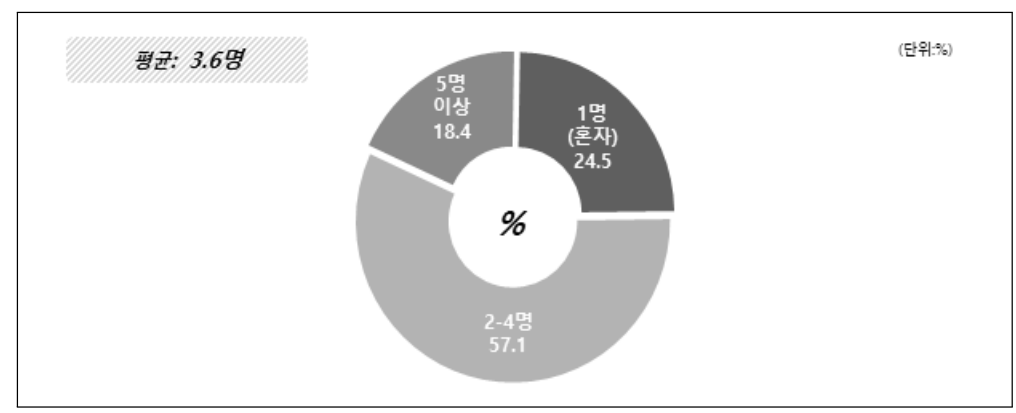

5) 여행 형태

- 김해공항을 이용하는 외국인 관광객의 여행 형태는 '개별 여행' (88.9\%)이 '패 키지 여행'(11.1\%)보다 많음

- '대만' 국적은 다른 국적에 비해 '패키지 여행' 으로 한국을 관광하는 경우가 $27.7 \%$ 로 높은 편임

[그림 3-4] 여행 형태_김해공항

(당위:\%)

6) 여행 기간

- 여행 기간은 ‘3일 초과 5일 이내'(39.5\%), '3일 이내'(32.9\%), '5일 초과 1주 일 이내'(10.1\%), '1주일 초과 10일 이내'(4.9\%) 등의 순임

- 국적별로 살펴보면 '일본' 국적은 평균 여행 기간이 3.6 일로 가장 짧고, '유럽' 국적은 평균 여행 기간이 17.7 일로 가장 길게 나타남 
[그림 3-5] 여행 기간_김해공항

(단위:\%)

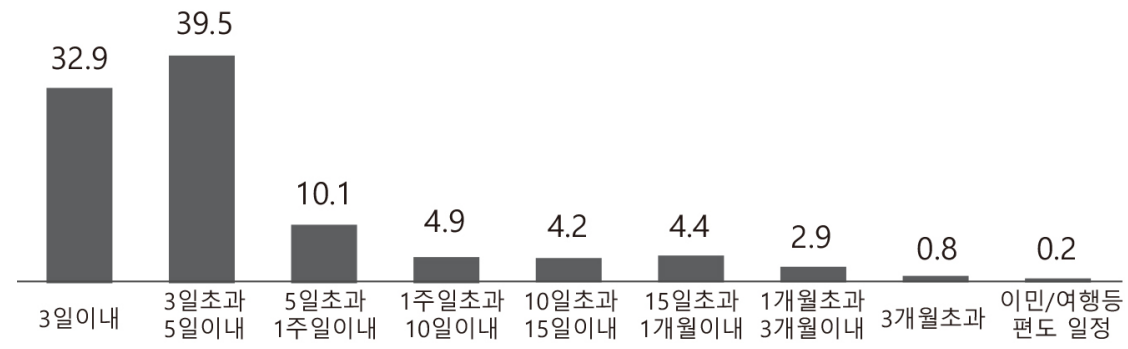

7) 방한 빈도

- 김해공항을 이용하는 외국인 관광객의 방한 빈도는 '두 번째 방문'이 $27.2 \%$ 로 가장 많음

- '일본' 국적의 경우 '세 번째 방문'(27.2\%)이 가장 많았으며, '다섯 번째 이상 방문 또한 $25.2 \%$ 로 다른 국적에 비해 많은 것으로 나타남

[그림 3-6] 방한 빈도_김해공항

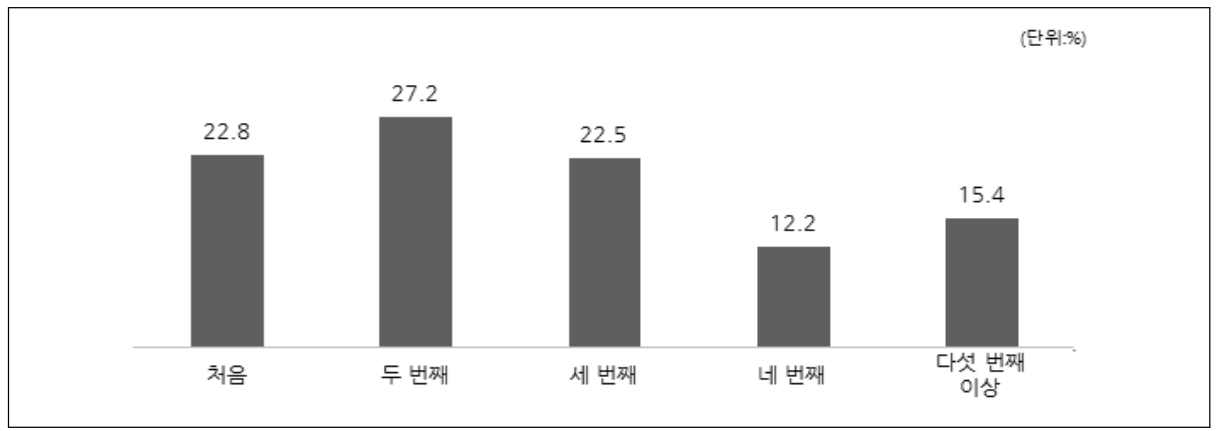

8) 항공권 구입 경로

- 항공권 구입 경로는 '온라인 사이트'(65.5\%), '여행사 홈페이지/모바일 앱' (15.7\%), ‘항공사 홈페이지/모바일 앱’(14.4\%) 등의 순임

- '외항사' 이용객이 다른 항공사 이용객보다 '온라인 사이트'(74.9\%)를 통해 항 공권을 구입하는 경우가 많음 
- 다섯 번 이상 방한한 관광객이 많은 '일본' 국적의 경우 '온라인 사이트' (73.8\%)를 통해 항공권을 구입하는 경우가 대다수임

[그림 3-7] 항공권 구입 경로_김해공항

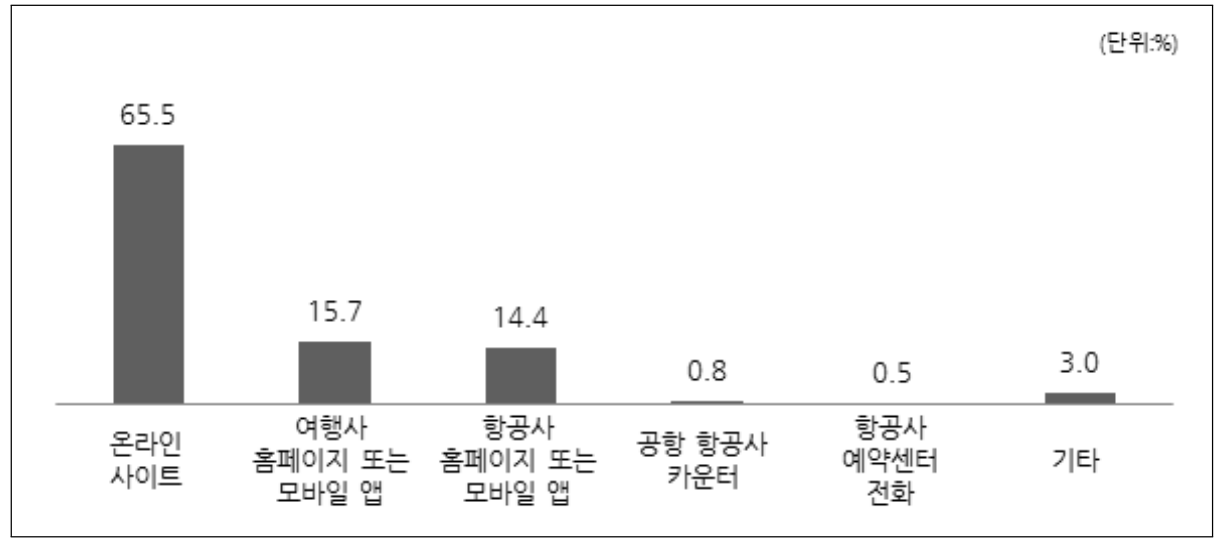

\section{나. 국내 입국 경로}

1) 국내 입국 공항

- 국내 입국시 이용 공항은 '김해공항'이 $88.6 \%$ 로 대다수이며 인천공항, 김포공 항, 대구공항, 제주공항을 통해 입국해 여행한 후 김해공항을 이용한 경우는 $11.4 \%$ 임

[그림 3-8] 국내 입국 공항_김해공항

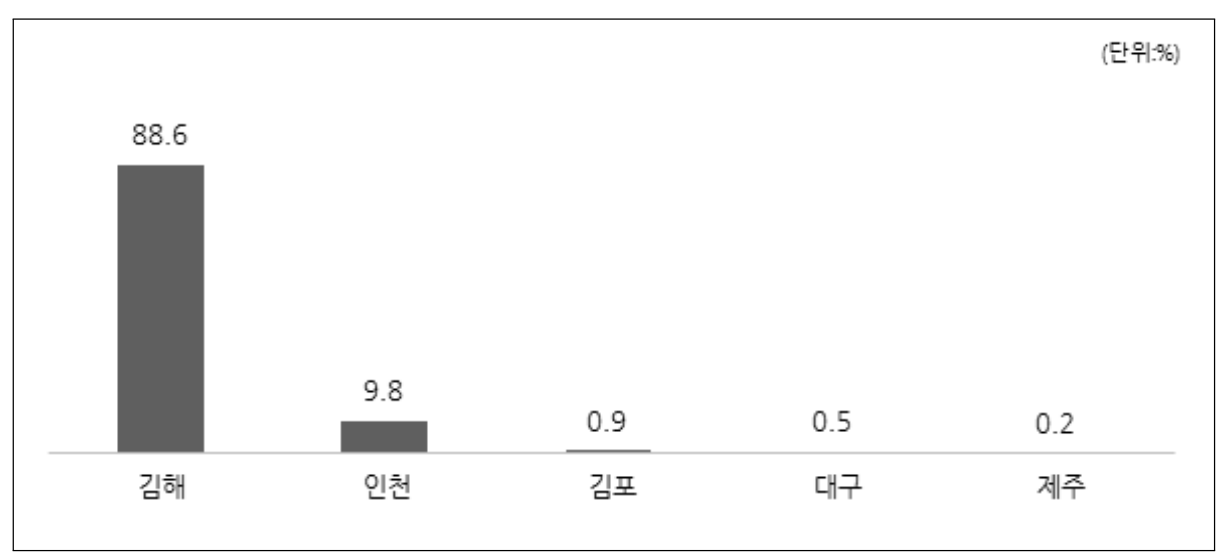




\section{2) 국내 입국 시 환승 여부}

- 국내 입국 시 '출발지에서 직항으로 한국에 들어왔다'는 응답이 94.9\%로 대다수임

- 한국을 처음 방문한 외국인 관광객은 다른 공항에서 환승을 통해 한국으로 들 어온 경우가 $13.3 \%$ 로 한국을 재방문한 외국인 관광객에 비해 많음

[그림 3-9] 국내 입국 시 환승 여부_김해공항

\begin{tabular}{|c|c|}
\hline 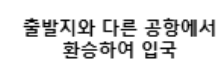 & (단위야의) \\
\hline
\end{tabular}

\section{다. 국내 지역 방문}

1) 국내 방문지

- 김해공항을 이용하는 외국인 관광객의 국내 방문지는 '부산'(84.9\%), '서울' (4.7\%), '경북'(2.1\%), '경남'(2.0\%) 등의 순임

- '미주' 국적 관광객은 다른 국적 대비 '서울'(19.6\%), '제주'(8.9\%), '대구'(7.1\%) 등 부산 이외 지역을 방문하는 경우가 많음

[그림 3-10] 국내 방문지(시도별)_김해공항

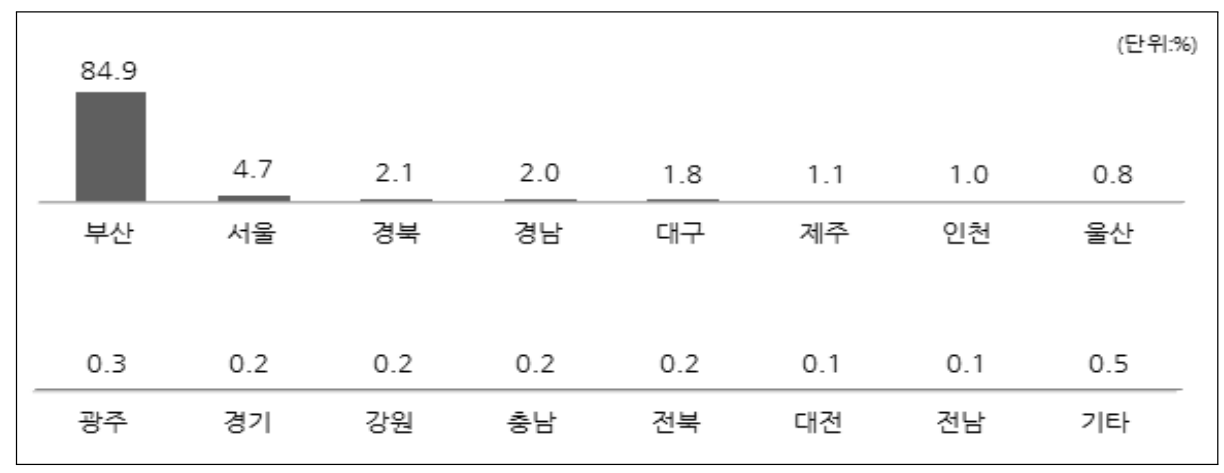




\section{2) 이용 교통수단}

- 방문지까지 이용한 교통수단은 ‘택시’(42.2\%), ‘지하철’(28.8\%), '여행사 차 량 $(14.6 \%)$ 등의 순임

- 국적별로 비교했을 때 '일본' 국적 관광객이 방문지까지 택시를 이용한 경우가 $56.6 \%$ 로 가장 많음

[그림 3-11] 국내 방문지까지 이용 교통수단_김해공항

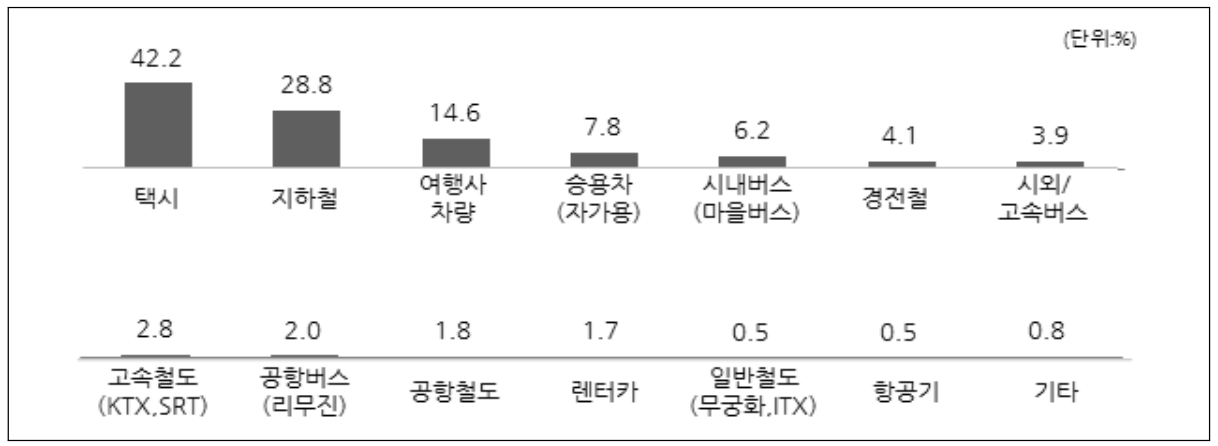

3) 이용 교통수단별 만족도

- 국내 방문지까지 이용한 교통수단 중 이용률이 가장 높은 ‘택시’의 경우 만족 도가 81.5점으로 나타남

- '항공기' 이용 만족도는 95.8점으로 교통수단 중 가장 높은 만족도를 보였으 며 '일반철도(무궁화, ITX)'는 75.0점으로 가장 낮은 만족도를 보임

[그림 3-12] 방문지까지 이용 교통수단별 만족도_김해공항

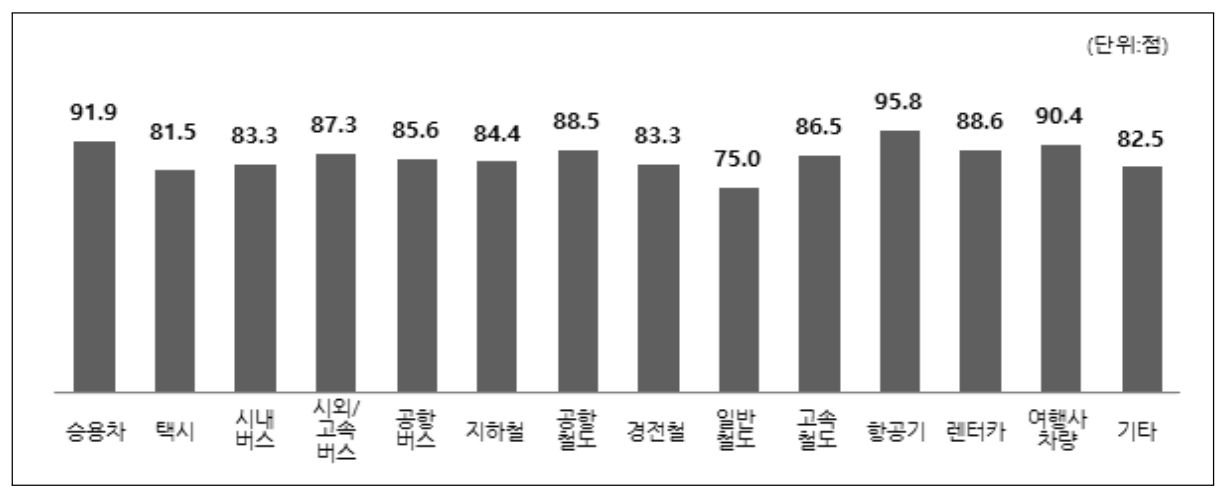




\section{라. 공항까지의 이동경로}

1) 공항으로 출발지역

- 김해공항으로 출발한 지역은 '부산'(93.5\%), '경남'(3.3\%), '울산'(1.2\%) 등의 순임

[그림 3-13] 공항으로 출발지역(시도별)_김해공항

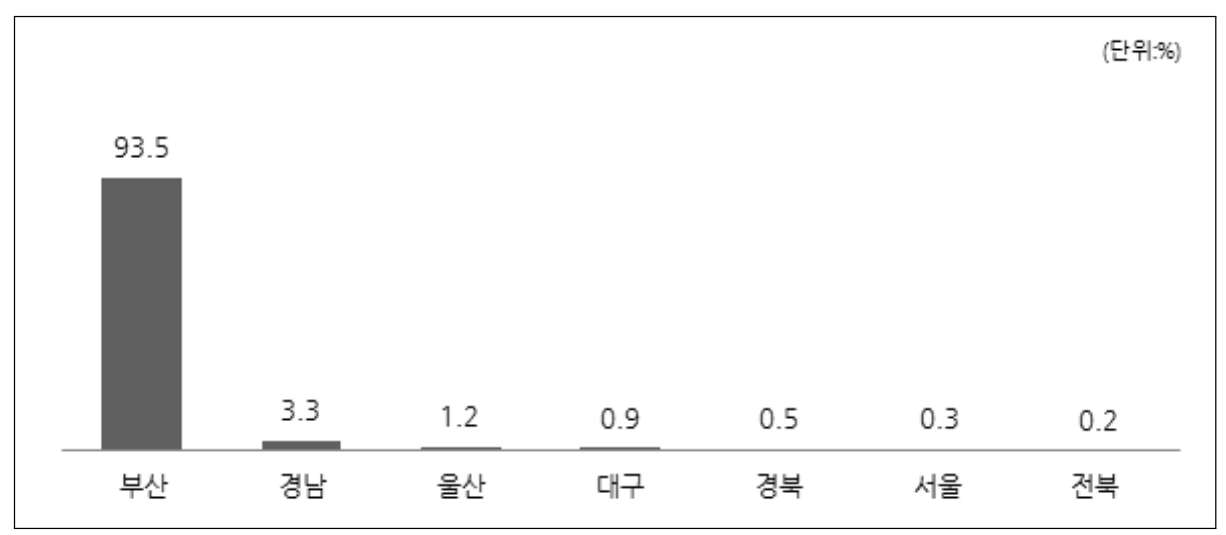

2) 공항 이동 교통수단

- 김해공항으로의 이동을 위해 이용한 교통수단은 '택시'(46.3\%), '지하철'(19.6\%), '경전철'(13.3\%), '승용차(자가용)'(11.5\%) 등의 순임

- '대양주/아프리카/기타' 국적 관광객은 '지하철'(54.5\%)을 더 많이 이용함

[그림 3-14] 공항 이동 교통수단_김해공항

\begin{tabular}{|c|c|c|c|c|c|c|}
\hline \multirow{2}{*}{46.3} & & & & & & (단위:9 \\
\hline & 19.6 & 13.3 & 11.5 & 10.1 & 7.0 & 3.7 \\
\hline 택시 & 지하철 & 경전철 & $\begin{array}{l}\text { 승용차 } \\
\text { (자가용) }\end{array}$ & 여행사 차량 & $\begin{array}{l}\text { 공항버스 } \\
\text { (리무진) }\end{array}$ & 공항철도 \\
\hline 2.1 & 1.2 & 0.9 & 0.3 & 0.3 & 0.2 & 0.2 \\
\hline $\begin{array}{l}\text { 시내버스 } \\
\text { (마을버스) }\end{array}$ & 렌터카 & $\begin{array}{c}\text { 시외/ } \\
\text { 고속버스 }\end{array}$ & $\begin{array}{c}\text { 일반철도 } \\
\text { (무궁화.ITX) }\end{array}$ & $\begin{array}{c}\text { 고속철도 } \\
\text { (KTX.SRT) }\end{array}$ & 항공기 & 기타 \\
\hline
\end{tabular}


3) 공항 이동 교통수단 이용 이유

- 해당 교통수단을 선택한 이유는 '탑승지 위치 및 교통 연계성이 좋아서'(58.4\%), '탑승지 편의시설이 좋아서'(31.9\%), '총 소요시간이 짧아서’(25.7\%) 등의 순임

- 공항 이동시 가장 많이 이용하는 ‘택시’의 경우 ‘탑승지 위치 및 교통 연계성 이 좋아서' 이용한다는 응답이 $55.8 \%$ 로 나타남

[그림 3-15] 공항 이동 교통수단 이용 이유_김해공항

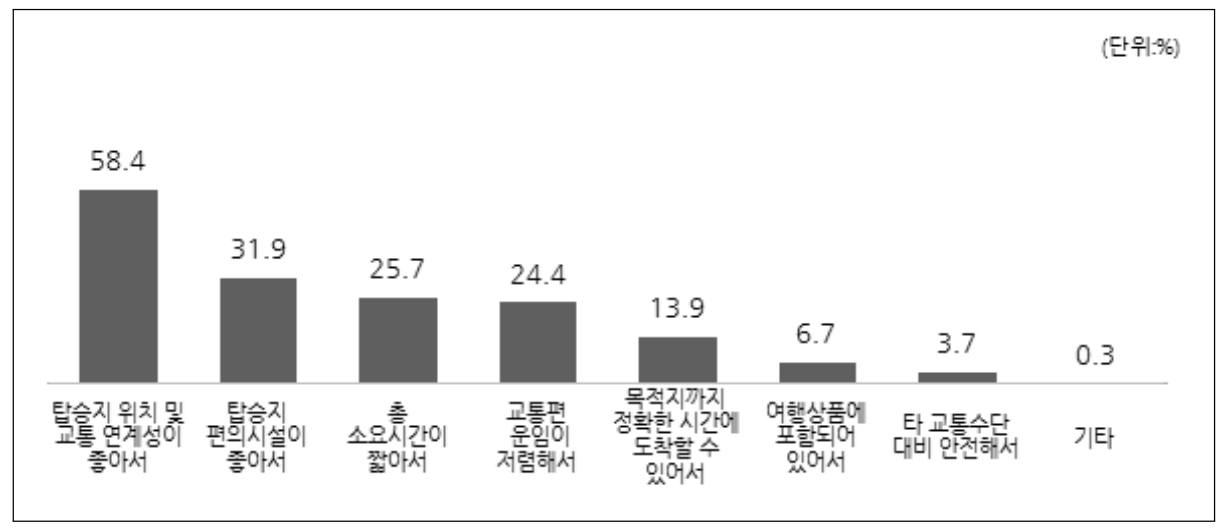

4) 공항 이동 교통수단 이용 만족도

- 공항 이동 교통수단에 대한 만족도는 '만족한다'는 의견이 $93.4 \%$ 로 대다수이 고 100점 평균 85.2점으로 나타남

[그림 3-16] 공항 이동 교통수단 이용 만족도_김해공항

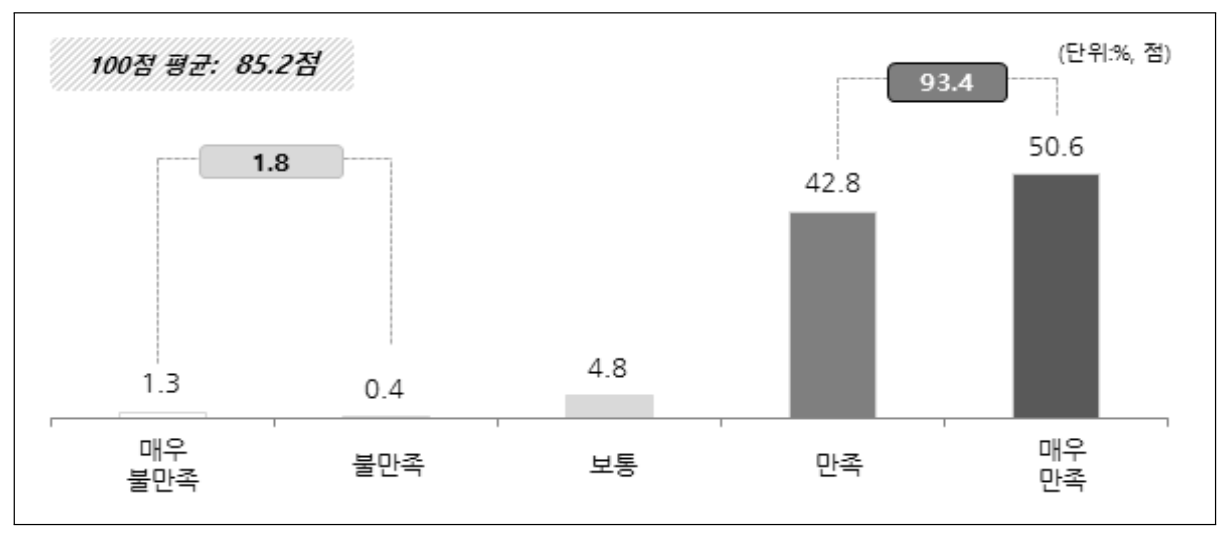


5) 공항 이동 교통수단 불만족 이유

- 공항 이동 교통수단별 불만족 이유는 다음과 같음

〈표 3-7〉 공항 이동 교통수단별 불만족 이유_김해공항

Base: 김해공항 관광목적 외국인 이용객 중 공항 이동 교통수단 불만족 응답자환승객 제외), $\mathrm{n}=2$, 단위:건

\begin{tabular}{c|c|c}
\hline 이용 교통수단 & 불만족 이유 & 사례수(건) \\
\hline 택시 & 과속 운전 & 1 \\
\hline 공항버스(리무진) & 짐 보관에 관한 안내가 부족함 & 1 \\
\hline
\end{tabular}

6) 공항 이동 소요시간

- 공항 이동 소요시간은 ' 1 시간 미만'이 $87.2 \%$ 로 대다수임

- 공항 이동시 평균 42 분이 소요되는 것으로 나타남

- '부산'에서 출발한 경우에는 평균 38.8 분이 소요됨

[그림 3-17] 공항 이동 소요시간_김해공항

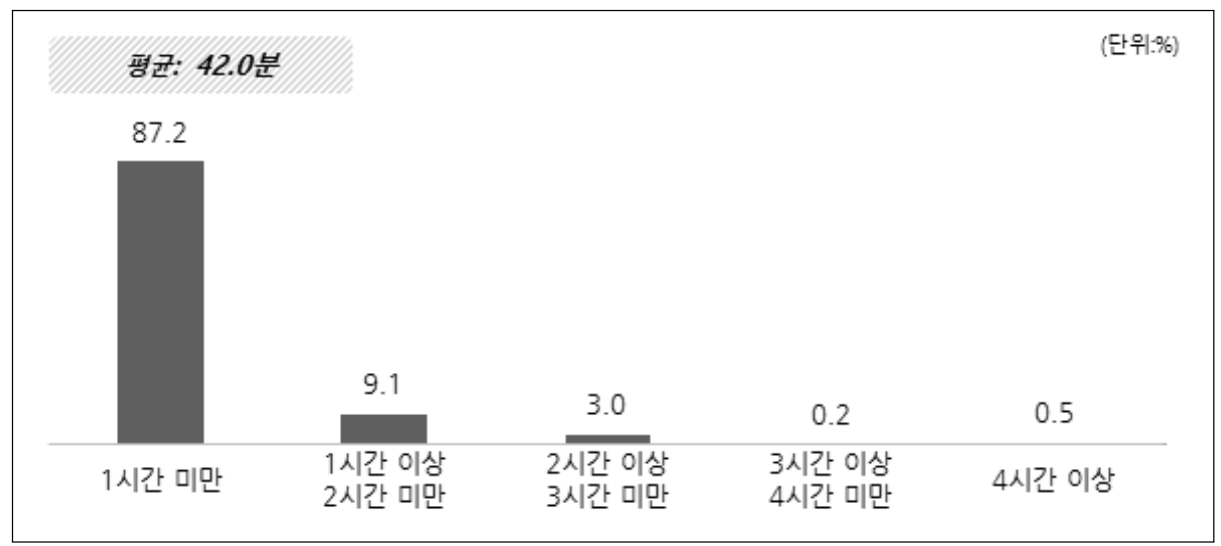

\section{마. 최종 목적지 및 환승 현황}

1) 최종 목적지 국가

- 김해공항 이용 외국인 관광객들의 최종 목적지 국가는 '일본'(45.8\%), '대만'(20.6\%), '중국' $(12.3 \%)$ 등의 순임 
[그림 3-18] 최종 목적지 국가_김해공항

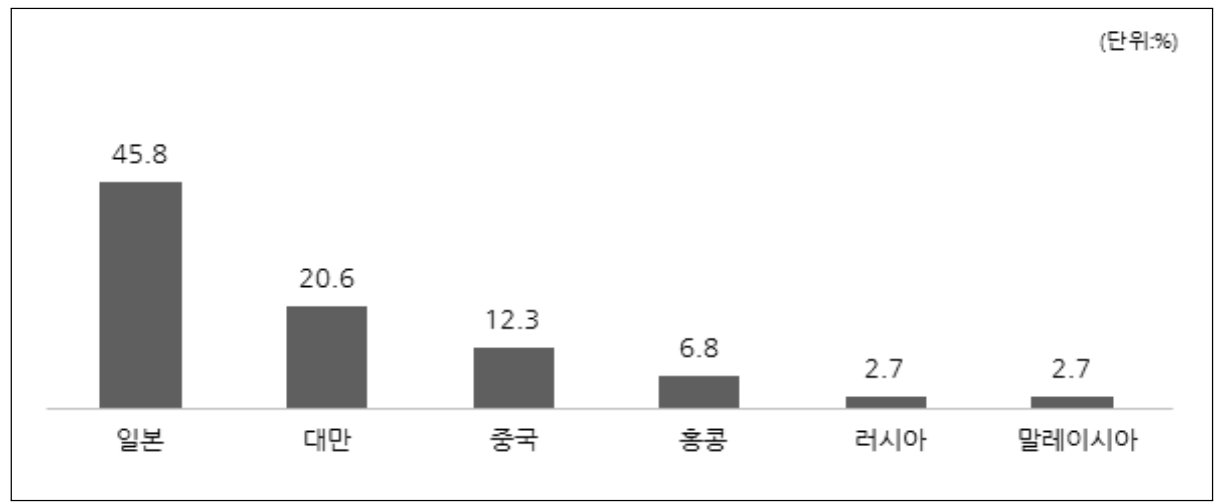

2) 한국 외 타 국가 방문 여부

- 김해공항을 이용하는 외국인 관광객 중 한국만 방문하는 경우는 $87.7 \%$, 타 국가도 방문하는 경우는 $12.3 \%$ 로 나타남

- '미주' 국적 관광객의 경우 다른 국적보다 한국 외 다른 국가도 방문하는 경우 가 $63.3 \%$ 로 많음

[그림 3-19] 한국 외 타 국가 방문 여부_김해공항

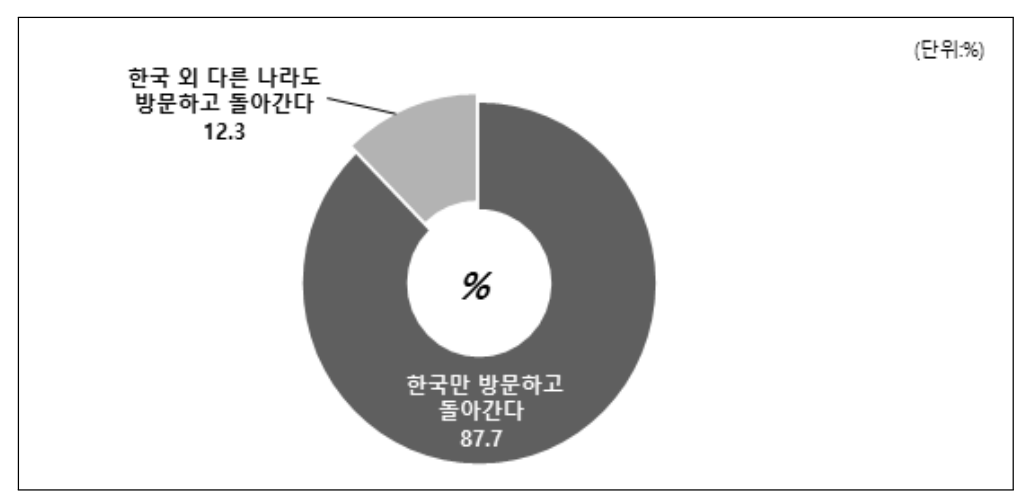

3) 타 국가 방문 시 환승 여부

- 다른 나라 방문 후 귀국 예정인 관광객의 경우 '환승이 아닌 일반적인 비행편 이용을 위해 왔다'는 응답이 $72.6 \%$ 로 '환승을 위해 왔다'(27.4\%)는 응답보다 높게 나타남 
[그림 3-20] 타 국가 방문 시 환승 여부_김해공항

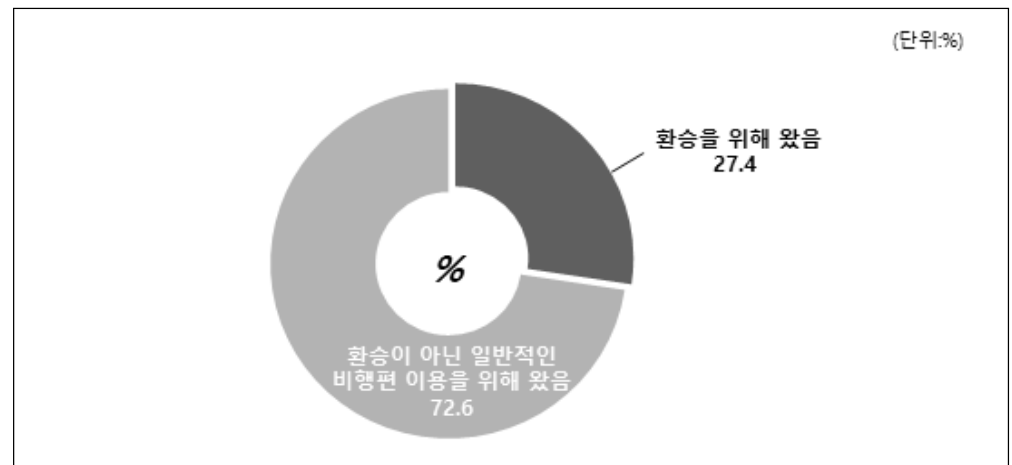

\section{4) 환승 유형}

- 환승 유형3)은 ‘환승 여객’이 70.0\%로 가장 많으며, '통과 여객'(20.0\%), '스톱 오버'(10.0\%) 순임

[그림 3-21] 환승 유형_김해공항

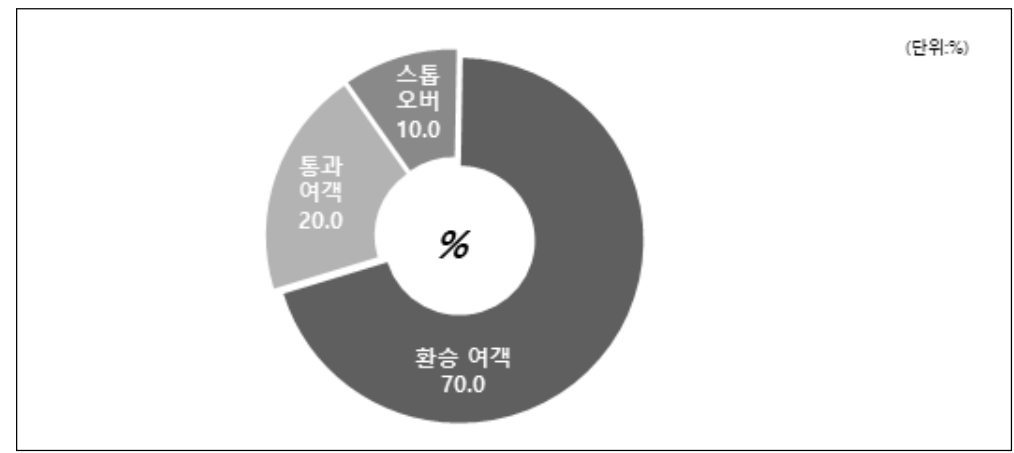

5) 환승 공항 선택 이유

- 환승 공항으로 김해공항을 선택한 이유는 ‘항공요금이 저렴하기 때문에’(70.0\%), '여행일정에 맞는 항공 스케줄이기 때문에'(65.0\%)가 대다수임

3) 주: 한국공항공사, 인천국제공항공사,『항공통계」이용자용 통계정보보고서, 2018.12.

- 스톱오버(Stopover traffic): 경유지가 있는 항공여정, 단일 항공권 또는 운송장에 지점 간 이동하며 단순 경유 또는 환승에 요구되는 시간동안 체류(이례적이나 하루 밤 동안 체류하기도 함)

- 통과여객(Direct transit Passengers): 경유하는 공항에서 같은 편명의 운항편으로 여행을 계속하는 여객

- 환승여객(Transfer Passengers): 경유하는 공항에서 다른 편명의 운항편으로 여행을 계속하는 여객 
[그림 3-22] 환승 공항 선택 이유_김해공항

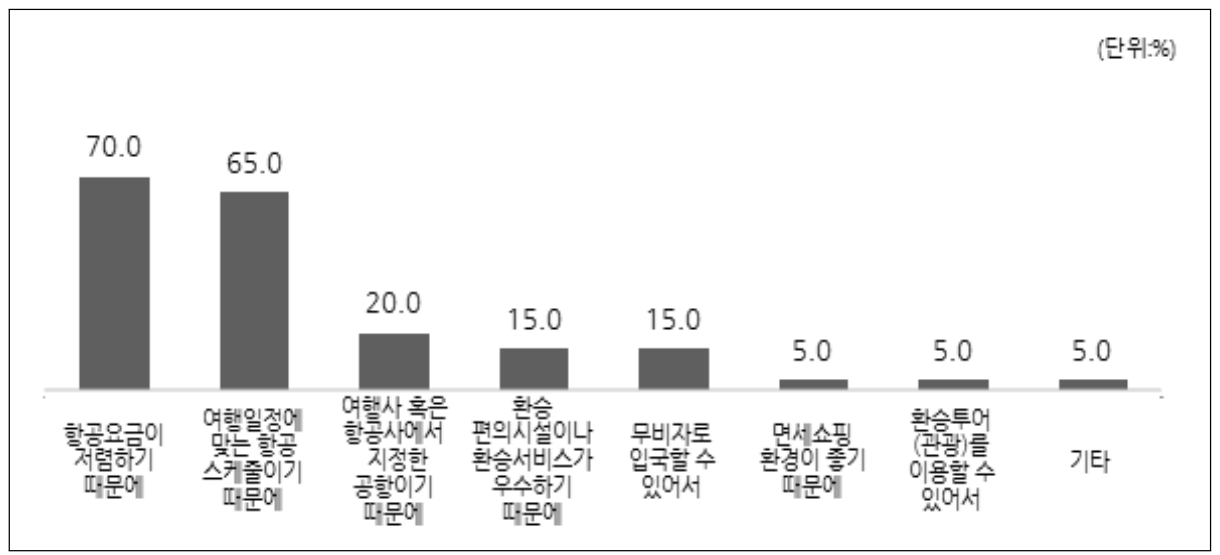

\section{3. 무안공항 분석결과}

\section{가. 방한 여행 형태}

\section{1) 응답자 특성}

- 무안공항을 이용하는 외국인 관광객의 국적은 '일본'(30.6\%), '대만'(26.9\%), '태국'(15.7\%), '중국'(10.2\%) 등의 순임

- FSC나 외항사에 비해 LCC(88.9\%) 이용 비율이 매우 높게 나타남

- '개별여행'인 경우가 84.3\%로 ‘패키지여행'(15.7\%) 보다 높음

- 한국을 '처음 방문'(45.4\%)한 외국인 관광객이 '재방문(2-4회)'(36.1\%)하거나 ‘자주 방문(5회 이상)'(18.5\%)한 관광객보다 많음

\section{〈표 3-8〉 무안공항 응답자 특성}

Base: 무안공항 관광목적 외국인 이용객, $\mathrm{n}=108$, 단위: \%

\begin{tabular}{|c|c|c|c|}
\hline \multicolumn{2}{|c|}{ 구분 } & 사례수 & 구성비(\%) \\
\hline \multicolumn{2}{|c|}{ 전체 } & (108) & 100.0 \\
\hline \multirow{2}{*}{ 성별 } & 남성 & (59) & 54.6 \\
\hline & 여성 & (49) & 45.4 \\
\hline
\end{tabular}




\begin{tabular}{|c|c|c|c|}
\hline \multicolumn{2}{|r|}{ 구분 } & 사례수 & 구성비(\%) \\
\hline \multirow{6}{*}{ 연령별 } & 15세-20세 미만 & (2) & 1.9 \\
\hline & 20대 & (29) & 26.9 \\
\hline & 30대 & (44) & 40.7 \\
\hline & 40대 & (17) & 15.7 \\
\hline & 50대 & (10) & 9.3 \\
\hline & 60대 이상 & (6) & 5.6 \\
\hline \multirow{2}{*}{ 여행 행태별 } & 개별 여행 & (91) & 84.3 \\
\hline & 패키지 여행 & (17) & 15.7 \\
\hline \multirow{2}{*}{ 여행 동반인별 } & 혼자 여행 & (50) & 46.3 \\
\hline & 동반 여행 & (58) & 53.7 \\
\hline \multirow{3}{*}{ 방한 빈도별 } & 처음 방문 & (49) & 45.4 \\
\hline & 재방문(2-4회) & (39) & 36.1 \\
\hline & 자주 방문(5회 이상) & (20) & 18.5 \\
\hline \multirow{3}{*}{$\begin{array}{c}\text { 이용 } \\
\text { 항공사별 }\end{array}$} & FSC & (2) & 1.9 \\
\hline & LCC & (96) & 88.9 \\
\hline & 외항사 & (10) & 9.3 \\
\hline \multirow{6}{*}{ 국적별 } & 중국 & (11) & 10.2 \\
\hline & 일본 & (33) & 30.6 \\
\hline & 미주 & (2) & 1.9 \\
\hline & 기타 아시아 & (55) & 50.9 \\
\hline & 유럽 & (6) & 5.6 \\
\hline & 대양주/아프리카/기타 & (1) & 0.9 \\
\hline \multirow{13}{*}{ 세부 국적별 } & 중국 & (11) & 10.2 \\
\hline & 일본 & (33) & 30.6 \\
\hline & 미국 & (2) & 1.9 \\
\hline & 대만 & (29) & 26.9 \\
\hline & 태국 & (17) & 15.7 \\
\hline & 필리핀 & (1) & 0.9 \\
\hline & 베트남 & (3) & 2.8 \\
\hline & 말레이시아 & (1) & 0.9 \\
\hline & 러시아 & (3) & 2.8 \\
\hline & 인도네시아 & (2) & 1.9 \\
\hline & 기타 아시아 & (2) & 1.9 \\
\hline & 유럽 & (3) & 2.8 \\
\hline & 기타 & (1) & 0.9 \\
\hline
\end{tabular}




\section{2) 여행 목적}

- 여행 목적은 '여가/위락/개별휴가'(71.3\%)와 '친구, 친지 방문'(21.3\%)이 대 다수임

- '자주 방문(5회 이상)'하는 관광객은 5 회 미만 관광객보다 '여가/위락/개별휴 가'(80.0\%)로 한국에 오는 경우가 많음

[그림 3-23] 여행 목적_무안공항

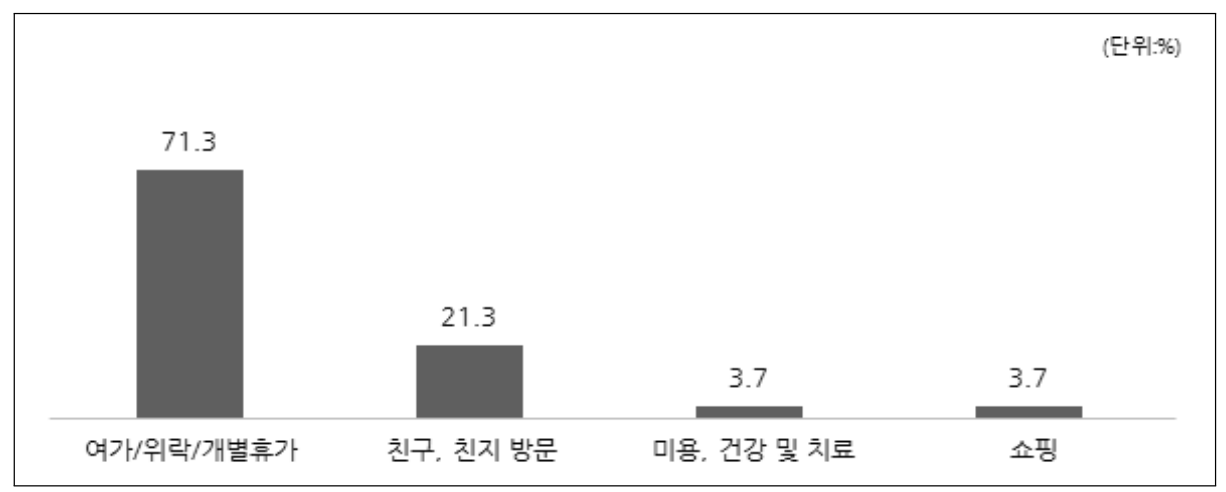

3) 여행 동반자 형태

- 여행 동반자 유형은 '혼자'(46.3\%), '가족/친지'(25.0\%), '친구'(22.2\%) 등의 순임

- '대만' 국적은 '친구'(58.6\%)와 함께 여행을 오는 경우가 가장 많음

[그림 3-24] 여행 동반자 형태_무안공항

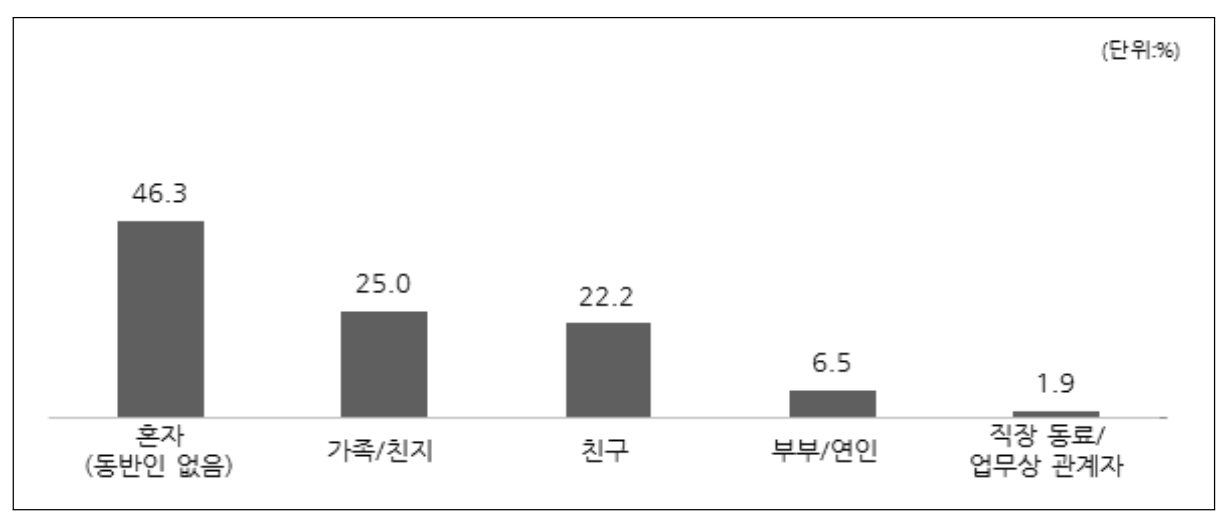




\section{4) 여행 인원}

- '1명(혼자)'(46.3\%), '2-4명'(34.3\%), '5명 이상'(19.4\%) 등의 순임

- 가족/친지인 경우 평균 6.9명, 부부/연인인 경우 평균 16.3 명, 직장 동료인 경우 평균 47.5 명, 친구인 경우는 평균 5.2 명이 함께 여행함

- 무안공항을 이용하는 외국인 관광객의 여행 인원은 평균 5.2 명임

\section{[그림 3-25] 여행 인원_무안공항}

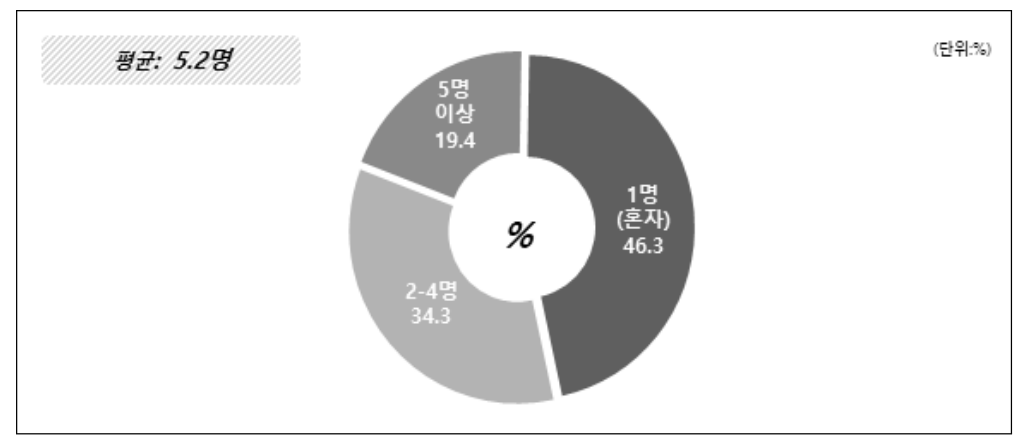

5) 여행 형태

- 무안공항을 이용하는 외국인 관광객의 여행 형태는 '개별 여행' (84.3\%)이 '패 키지 여행'(15.7\%) 보다 많음

- 연령이 높을수록 ‘패키지 여행'을 이용하는 경우가 많아지는 경향이 있음

[그림 3-26] 여행 형태_무안공항

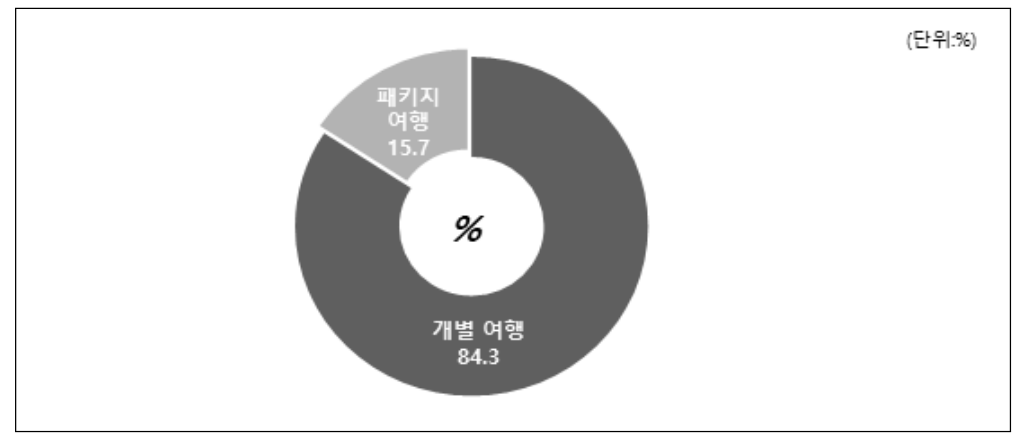




\section{6) 여행 기간}

- 여행 기간은 ‘3일 초과 5일 이내'(44.4\%), ‘3일 이내'(13.0\%), ' 15 일 초과 1 개 월 이내'(11.1\%), ‘5일 초과 1 주일 이내’(9.3\%) 등의 순임

- 국적별로 살펴보면 '일본' 국적의 평균 여행 기간이 4.7일로 가장 짧고, '미주' 국적의 평균 여행 기간이 95일로 가장 긺

[그림 3-27] 여행 기간_무안공항

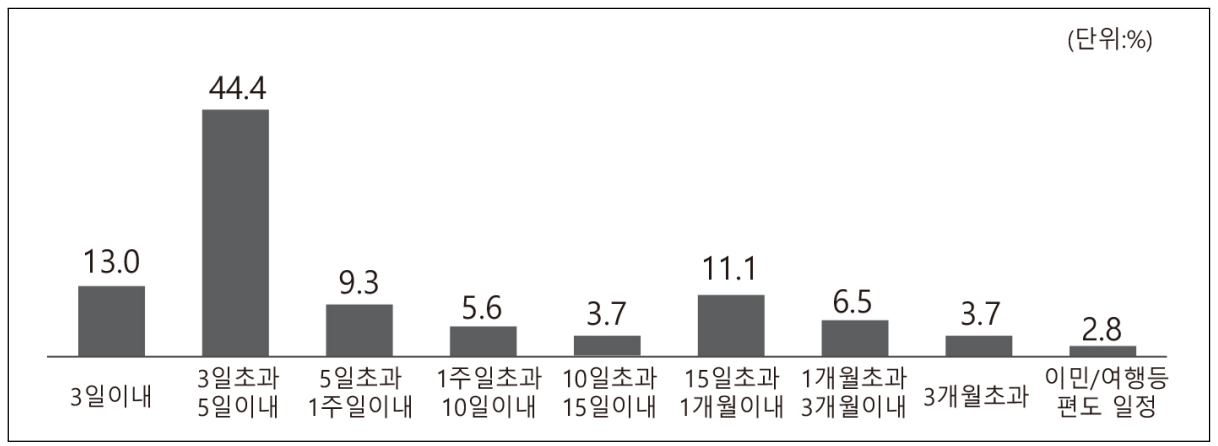

\section{7) 방한 빈도}

- 무안공항을 이용하는 외국인 관광객의 방한 빈도는 '처음 방문'이 $45.4 \%$ 로 가장 많음

- '일본' 국적 관광객의 경우 '다섯 번 이상 방문'한 경우가 $33.3 \%$ 로 다른 국적 에 비해 많음

[그림 3-28] 방한 빈도_무안공항

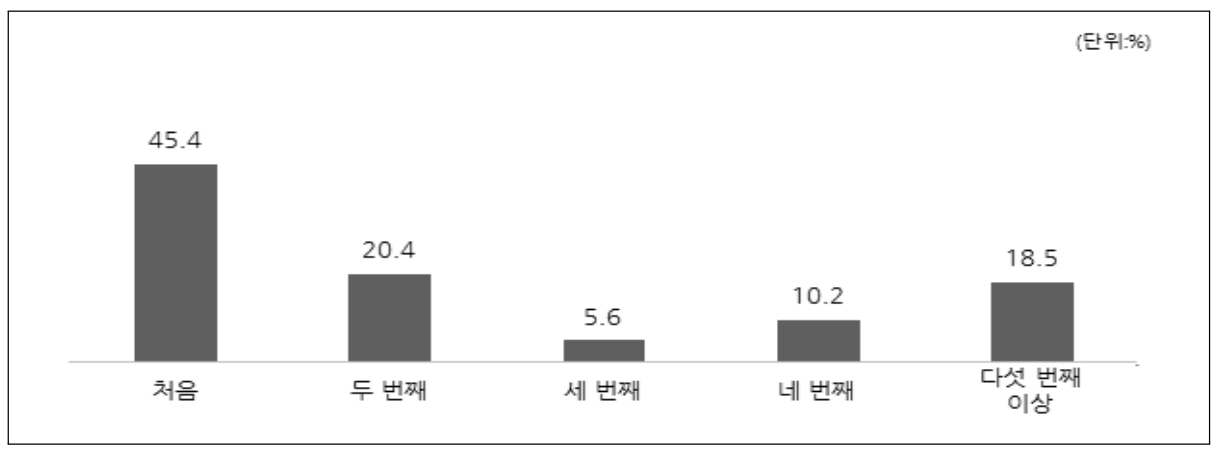


8) 항공권 구입 경로

- 항공권 구입 경로는 '온라인 사이트'(68.5\%), '여행사 홈페이지 또는 모바일 압'(21.3\%)이 대부분임

- 특히 '중국' 국적 관광객은 '온라인 사이트'(63.6\%), '항공사 예약센터 전화' (27.3\%)를 통해 항공권을 구입하는 경우가 많음

[그림 3-29] 항공권 구입 경로_무안공항

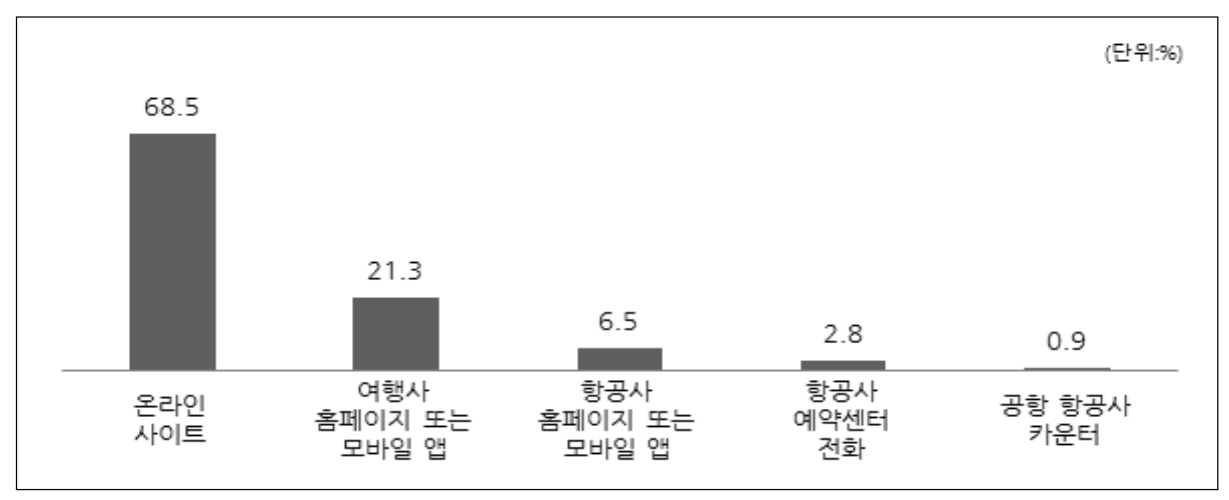

\section{나. 국내 입국 경로}

\section{1) 국내 입국 공항}

- 국내 입국 시 이용한 공항은 ‘무안공항'이 $86.1 \%$ 로 대다수이며 인천공항, 김 해공항, 제주공항, 김포공항을 통해 입국하여 여행한 후 무안공항을 이용한 경우는 $13.9 \%$ 임

[그림 3-30] 국내 입국 공항_무안공항

(단위:\%)

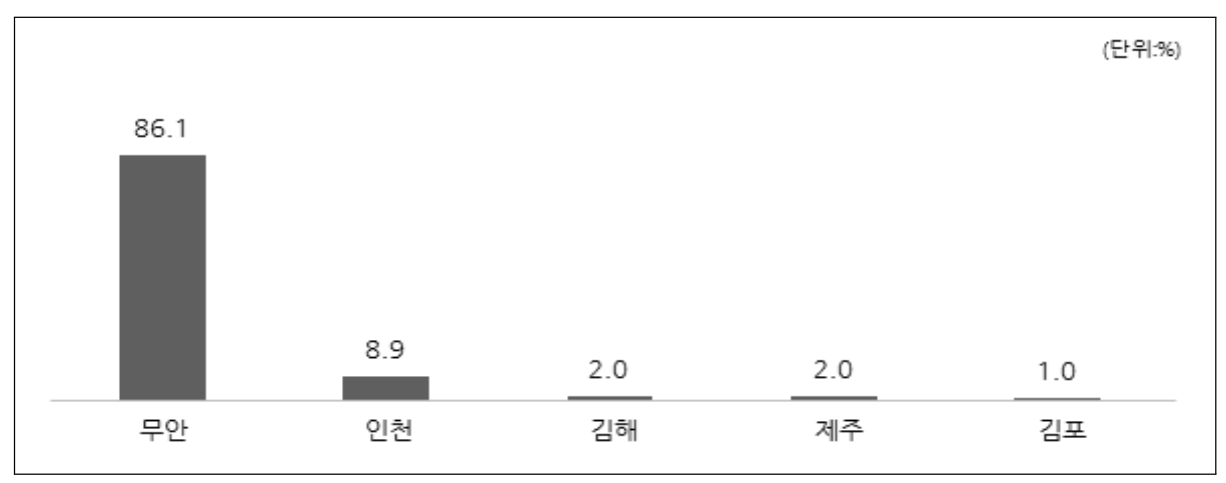


2) 국내 입국 시 환승 여부

- 국내 입국 시 '출발지에서 직항으로 한국에 들어왔다'는 응답이 $94.1 \%$ 로 대다 수임

[그림 3-31] 국내 입국 시 환승 여부_무안공항

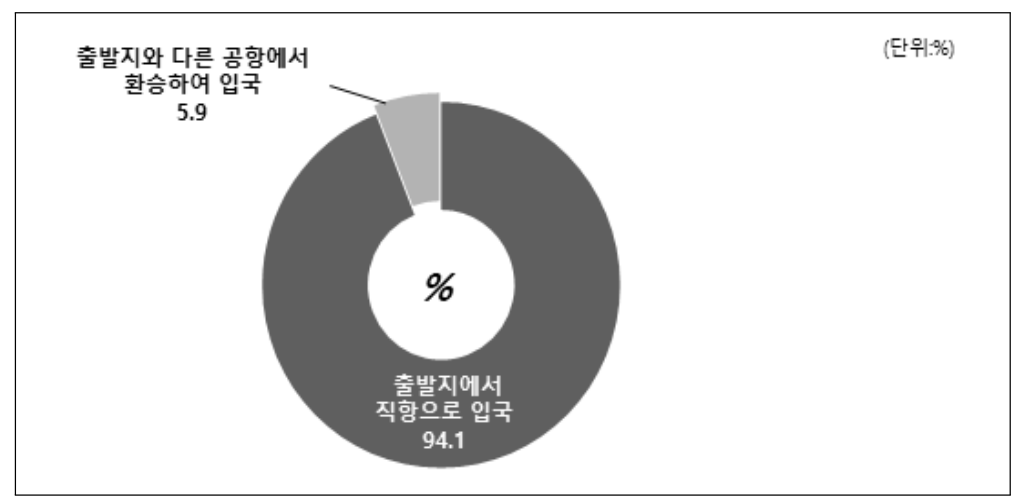

\section{다. 국내 지역 방문}

1) 국내 방문지

- 무안공항을 이용하는 외국인 관광객의 국내 방문지는 '전남'(36.3\%), '광주'(33.1\%), '부산'(10.2\%), '서울' $(5.1 \%)$ 등의 순임

- 한국을 '처음 방문'한 관광객은 '광주’(35.2\%)를 가장 많이 방문함

[그림 3-32] 국내 방문지(시도별)_무안공항

\begin{tabular}{|c|ccccc|}
\hline 36.3 & 33.1 & & & & (단위.\%) \\
\hline 전남 & 광주 & 부산 & 서울 & 전북 & 대구 \\
& & & & & \\
2.5 & 2.5 & 1.3 & 1.3 & 0.6 & 0.6 \\
\hline 인천 & 총남 & 대전 & 총북 & 경남 & 기타 \\
\hline
\end{tabular}




\section{2) 이용 교통수단}

- 방문지까지 이용한 교통수단은 '택시'(32.5\%), '시외/고속버스'(22.3\%), '승용 차(자가용)'(14.6\%) 등의 순임

- ' 60 대 이상' 관광객은 '시외/고속버스' $(54.5 \%)$ 를 이용하는 경우가 가장 많음

[그림 3-33] 방문지까지 이용 교통수단_무안공항

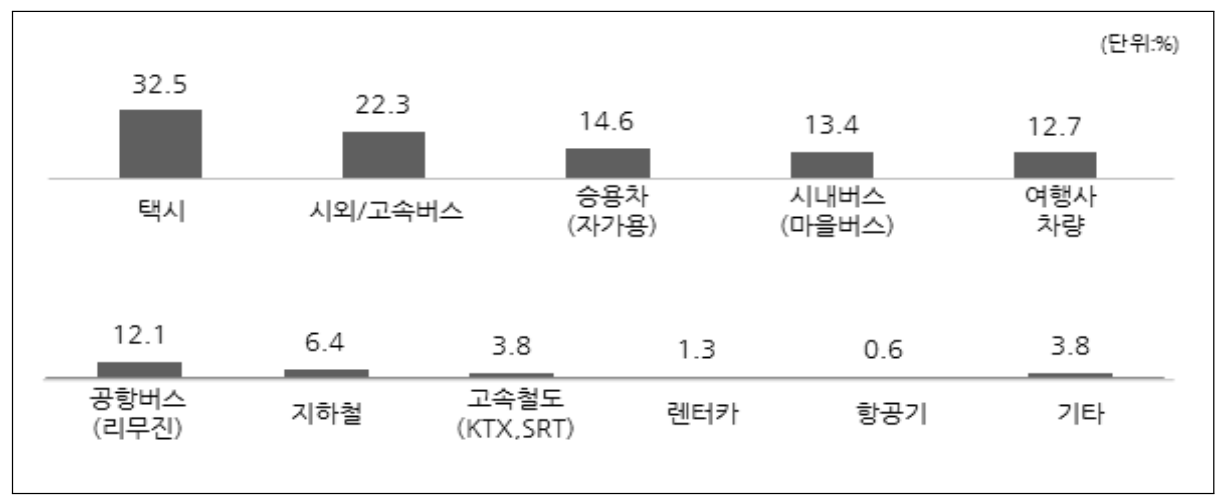

3) 이용 교통수단별 만족도

- 방문지까지 이용한 교통수단 중 이용률이 가장 높은 ‘택시’의 경우 만족도가 94.1점으로 나타남

- '고속철도'가 95.8점으로 가장 높은 만족도를 보였으며, '항공기'와 '렌터카' 는 75점으로 가장 낮은 만족도를 보임

[그림 3-34] 방문지까지 이용 교통수단별 만족도_무안공항

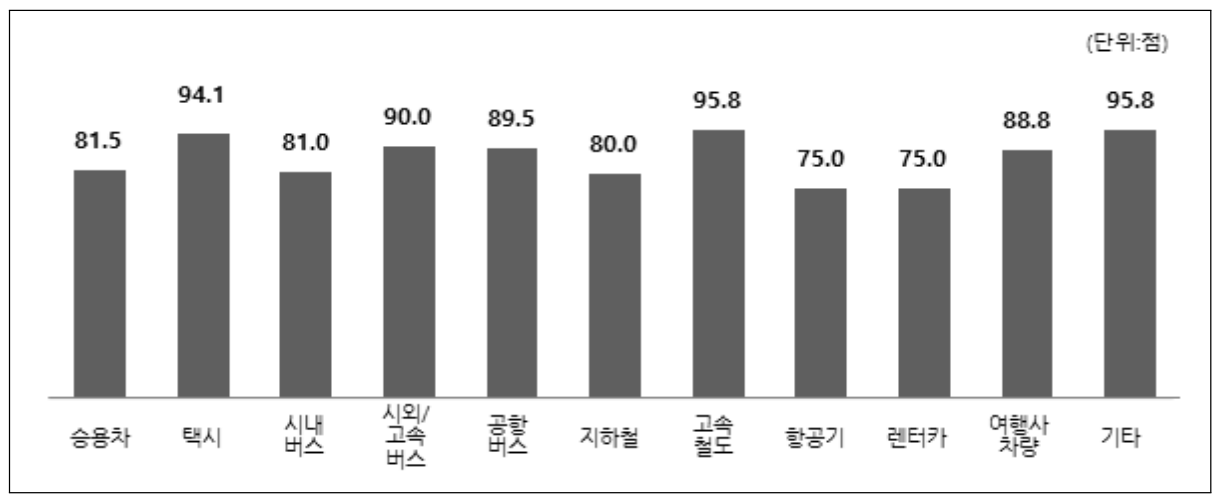




\section{라. 공항까지의 이동경로}

1) 공항으로 출발지역

- 무안공항으로 출발한 지역은 '광주'(48.5\%), '전남'(44.6\%), '부산'(5.0\%) 등 의 순임

- 시군구별로 살펴보면 '광주 광산구'가 $18.8 \%$ 로 가장 높은 비율을 보임

[그림 3-35] 공항으로 출발지역(시도별)_무안공항

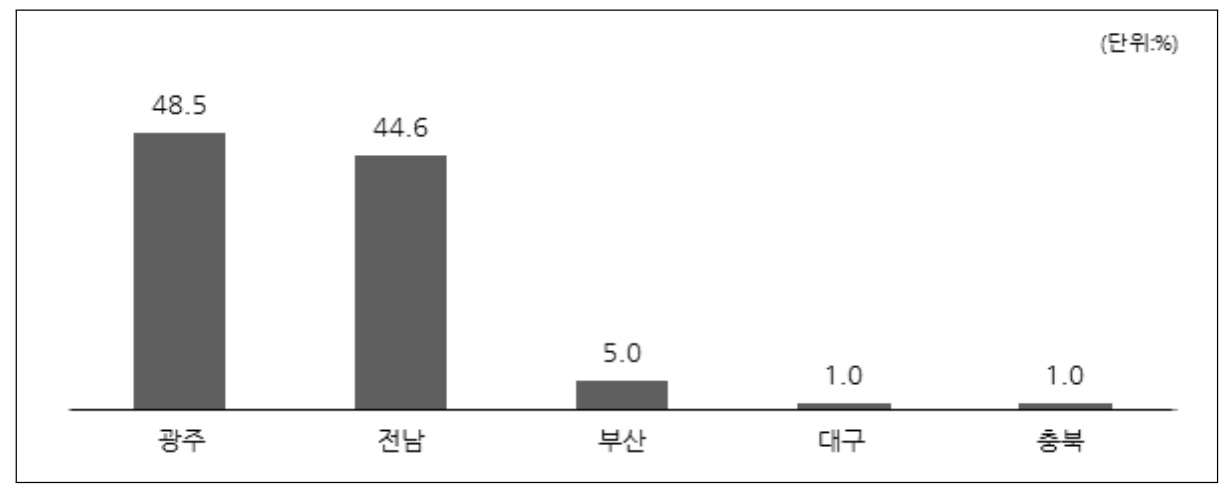

2) 공항 이동 교통수단

- 무안공항으로의 이동을 위해 이용한 교통수단은 '택시'(28.7\%), '승용차(자가 용)'(20.8\%), '시외/고속버스'(17.8\%) 등의 순임

- '일본' 국적 관광객의 경우 ‘승용차(자가용)'(27.6\%)을 더 많이 이용함

[그림 3-36] 공항 이동 교통수단_무안공항

\begin{tabular}{|ccccc|}
\hline 28.7 & 20.8 & 17.8 & 15.8 & \multicolumn{1}{c|}{ (단위\%) } \\
\hline 택시 & 승용차(자가용) & 시외/고속버스 & 공항버스(리무진) & 여행사 차량 \\
$\frac{5.9}{\text { 시내버스 }}$ & 1.0 & 1.0 & 1.0 & 5.9 \\
(마을버스) & 지하철 & 경전철 & $\begin{array}{c}\text { 고속철도 } \\
\text { (KTX.SRT) }\end{array}$ & 기타 \\
\hline
\end{tabular}


3) 공항 이동 교통수단 이용 이유

- '탑승지 위치 및 교통연계성이 좋아서'(57.3\%), '교통편 운임이 저렴해서' (36.4\%), '총소요시간이 짧아서'(21.8\%) 등의 순임

- 공항 이동시 가장 많이 이용하는 ‘택시’의 경우 ‘탑승지 위치 및 교통 연계성 이 좋아서' 이용한다는 응답이 $55.2 \%$ 로 나타남

[그림 3-37] 공항 이동 교통수단 이용 이유_무안공항

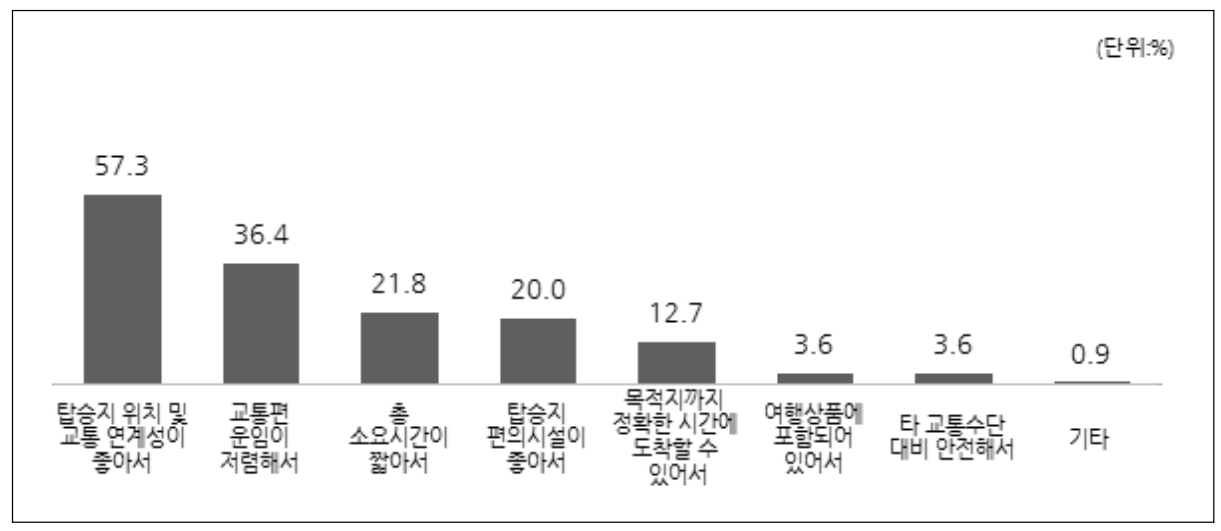

4) 교통수단 이용 만족도

- 공항 이동 교통수단에 대한 만족도는 '만족한다'는 의견이 $96.4 \%$ 로 대다수이 고 100점 평균 89.5점으로 나타남

[그림 3-38] 공항 이동 교통수단 이용 만족도_무안공항

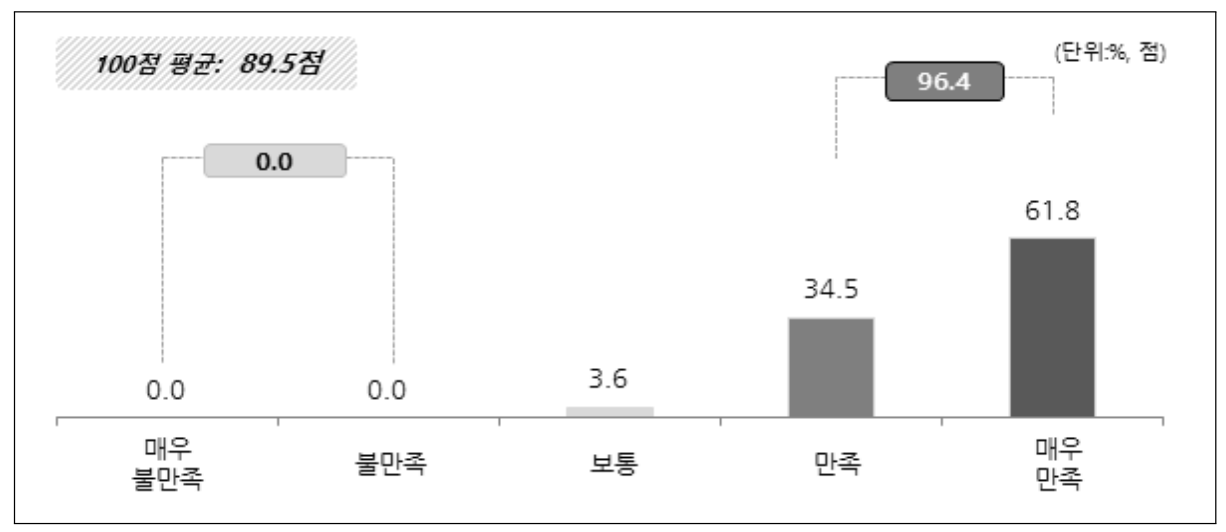


5) 공항 이동 소요시간

- 공항 이동 소요시간은 ' 1 시간 미만'이 $54.5 \%$ 로 가장 높으며 ' 1 시간 이상 2 시 간 미만'(28.7\%), ‘4시간 이상'(7.9\%) 등의 순임

- 공항 이동시 평균 83.7 분이 소요되는 것으로 나타남

- '광주'에서 출발한 경우 평균 55.5분이 소요되고, '전남'에서 출발한 경우 평 균 109.6분이 소요됨

[그림 3-39] 공항 이동 소요시간_무안공항

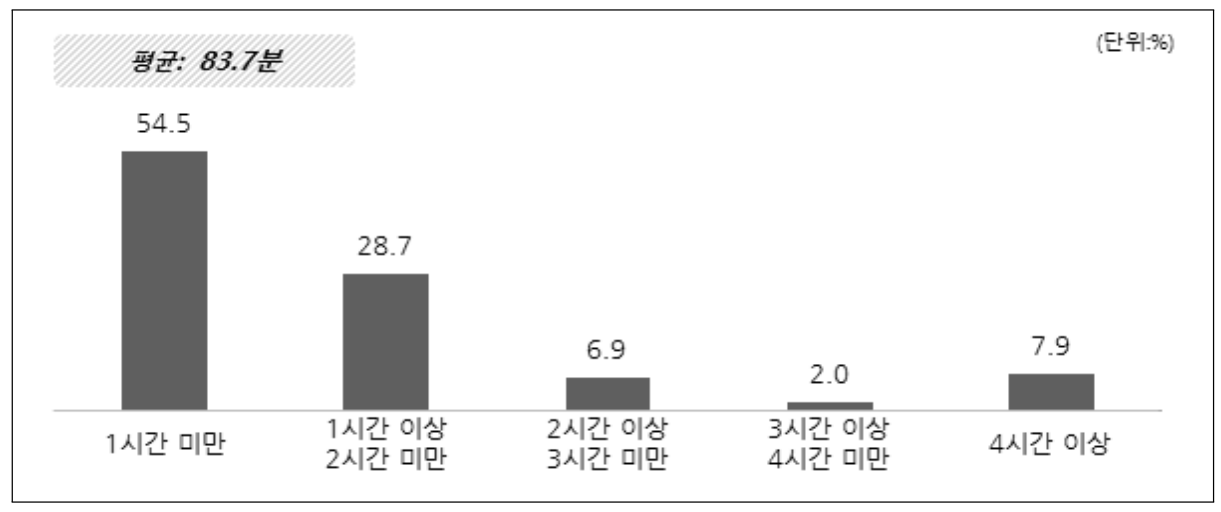

\section{마. 최종 목적지 및 환승 현황}

1) 최종 목적지 국가

- 최종 목적지 국가는 '대만'(30.6\%), '일본'(25.9\%), '태국'(14.8\%) 등의 순임 [그림 3-40] 최종 목적지 국가_무안공항

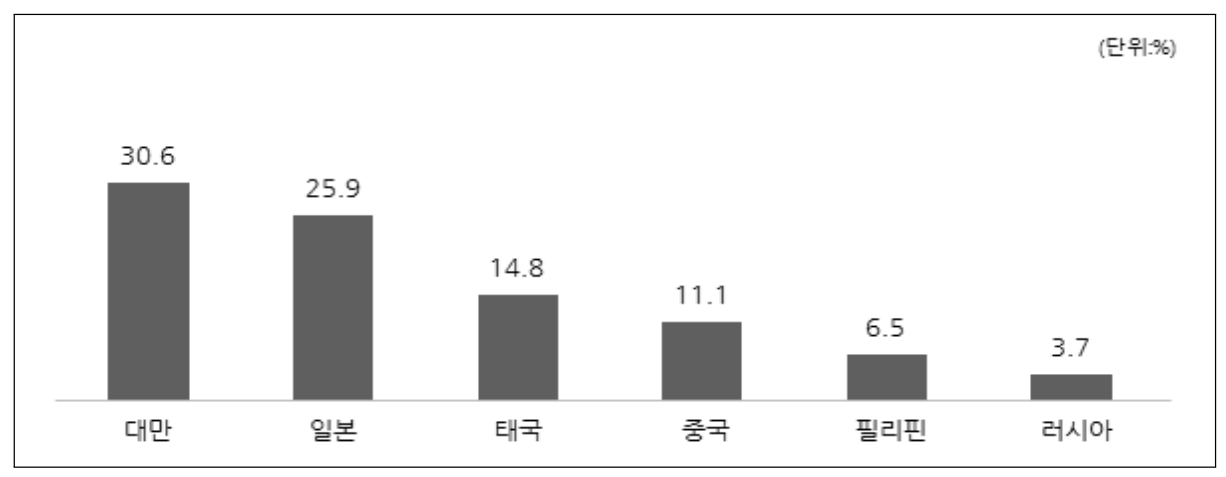


2) 한국 외 타 국가 방문 여부

- 무안공항을 이용하는 외국인 관광객 중 한국만 방문하는 경우는 $84.3 \%$, 타 국가도 방문하는 경우는 $15.7 \%$ 로 나타남

[그림 3-41] 한국 외 타 국가 방문 여부_무안공항

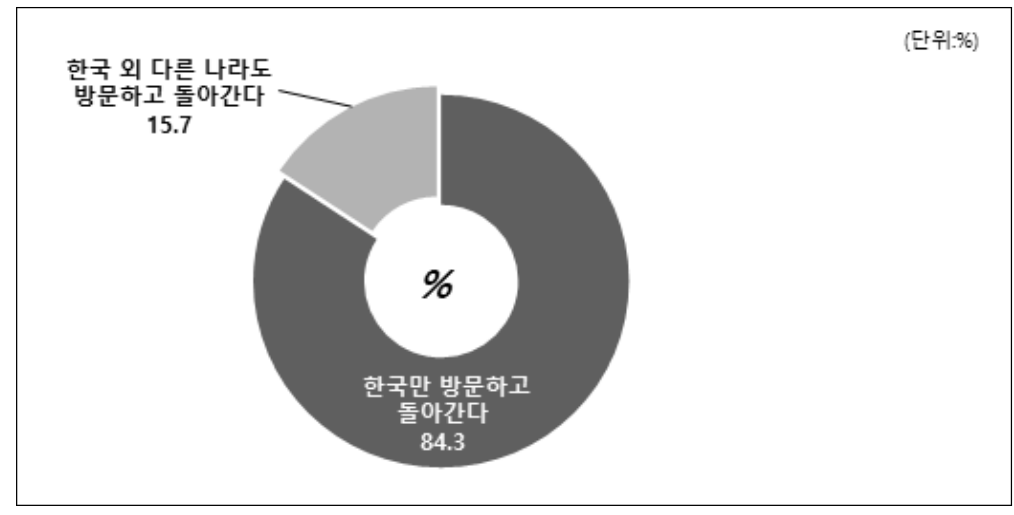

3) 타 국가 방문 시 환승 여부

- 다른 나라 방문 후 귀국 예정인 관광객의 경우 ‘환승이 아닌 일반적인 비행편 이용을 위해 왔다'는 응답이 $58.8 \%$ 로 '환승을 위해 왔다'(41.2\%)는 응답보다 높음

[그림 3-42] 타 국가 방문 시 환승 여부_무안공항

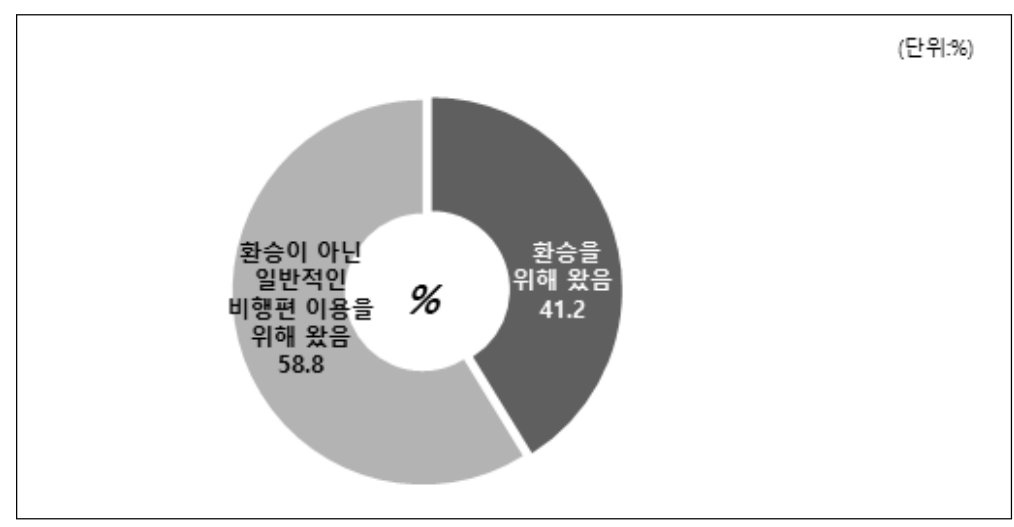




\section{4) 환승 유형}

- 환승 유형 4$)$ 은 '통과 여객'이 $57.1 \%$ 로 가장 많으며, '환승 여객'은 $42.9 \%$ 로 나타남

[그림 3-43] 환승 유형_무안공항

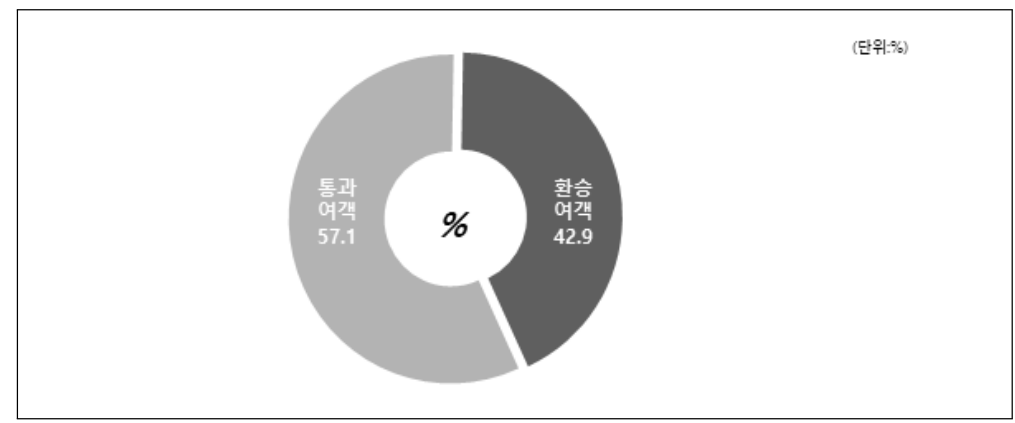

5) 환승 공항 선택 이유

- 환승 공항으로 무안공항을 선택한 이유는 '항공요금이 저렴하기 때문에' (85.7\%), '여행 일정에 맞는 항공 스케줄이기 때문에'(71.4\%), '여행사 혹은 항공사에서 지정한 공항이기 때문에'(28.6\%) 등의 순임

[그림 3-44] 환승 공항 선택 이유_무안공항

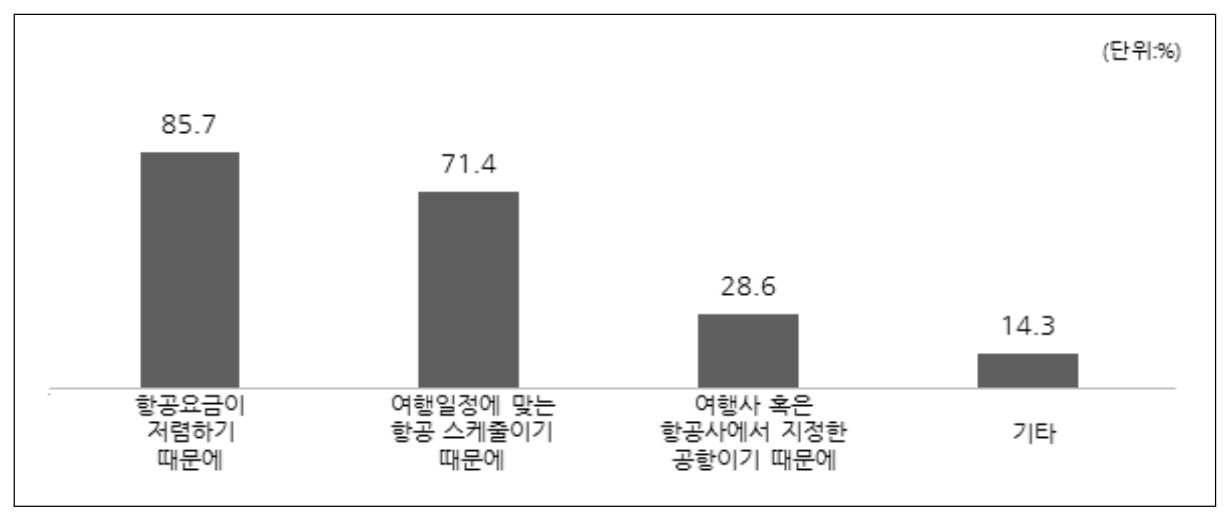

4) 주: 한국공항공사, 인천국제공항공사, 『항공통계」이용자용 통계정보보고서, 2018.12.

- 스톱오버(Stopover traffic): 경유지가 있는 항공여정, 단일 항공권 또는 운송장에 지점 간 이동하며 단순 경유 또는 환승에 요구되는 시간동안 체류(이례적이나 하루 밤 동안 체류하기도 함)

- 통과여객 (Direct transit Passengers): 경유하는 공항에서 같은 편명의 운항편으로 여행을 계속하는 여객

- 환승여객(Transfer Passengers): 경유하는 공항에서 다른 편명의 운항편으로 여행을 계속하는 여객 


\section{제2절 지방공항 이용 외국인 심층면접조사}

\section{1. 김해공항 이용객 심층면접조사}

\section{가. 응답자 특성}

김해공항 이용 경험이 있는 외국인 의견 수렴을 위한 심층면접 조사의 응답자 특 성은 다음과 같다.

〈표 3-9〉 김해공항 심층면접조사 응답자

\begin{tabular}{c|c|c|c|c}
\hline 이름 & 국적 & 성별 & 출생년도 & 직업 \\
\hline 타나카 $\times \times \times$ & 일본 & 여자 & 1996년 & 대학원생 \\
\hline 하나무라 $\times \times \times$ & 일본 & 여자 & 1969년 & 프리랜서, 통역 \\
\hline $\mathrm{YU} \times \times \times$ & 중국 & 여자 & 1990년 & 대학원생 \\
\hline ㄴ $\times \times \times$ & 중국 & 남자 & 1984년 & 교사 \\
\hline 라이 $\times \times \times$ & 대만 & 여자 & 1992년 & 회사원 \\
\hline 종 $\times \times \times$ & 대만 & 여자 & 1992년 & 회사원 \\
\hline Morry $\times \times \times$ & 미국 & 남자 & 1990년 & 영어교사 \\
\hline Kyle $\times \times \times$ & 캐나다 & 남자 & 1985년 & 영어교사 \\
\hline 오게쉬 $\times \times \times$ & 인도 & 남자 & 1996년 & 학생 \\
\hline 대니쉬 $\times \times \times$ & 파키스탄 & 남자 & 1995년 & 학생 \\
\hline
\end{tabular}

\section{나. 한국 여행 정보 획득}

1) 해외 현지에서 한국 여행 정보 획득 경로

- 김해공항 이용객 중 일본이나 중국 사람들은 해외 현지에서 사용하는 여행 사 이트를 대체로 이용하며, 영어권 사람들은 외국인이 사용하는 웹사이트나 한 국에 있는 가족으로부터 정보를 얻음 
- 파키스탄이나 인도 등 기타 국적의 사람들은 대부분 SNS를 통해 정보를 얻음

〈표 3-10〉 해외 현지에서 한국 여행 정보를 얻은 경로

\begin{tabular}{c|l}
\hline 국적 & \multicolumn{1}{c}{ 내용 } \\
\hline 일본 & - 인스타그램, 블로그, 코네스트, 서울나비, 부산나비 \\
\hline 중국 & - 구글, 바이두(포털사이트), 페이주(어플), 씨트립 \\
\hline 대만 & - 블로그, 한국관광공사 사이트 \\
\hline 영어권 & - 한국에 거주하고 있는 가족, DAVE'S ESL(웹사이트) \\
\hline 기타 & - 인스타그램, 페이스북, 유튜브, 구글 \\
\hline
\end{tabular}

2) 해당 경로를 사용한 이유

- 최근 정보를 빠르게 알 수 있고 실제 경험을 구체적으로 알 수 있다는 장점으 로 SNS를 많이 사용하고 있음

- 서울나비, 부산나비와 같은 사이트는 실제 경험에 근거한 자료가 많아 정보를 신뢰할 수 있어 많이 이용함

- 구글을 통한 검색은 접근성이 용이하기 때문에 많이 이용하고 있음

〈표 3-11〉 해당 경로를 사용한 이유

\begin{tabular}{c|c|l}
\hline \multicolumn{2}{|c|}{ 구분 } & \multicolumn{1}{c}{ 이유 } \\
\hline \multirow{4}{*}{ SNS } & 인스타그램 & - 최근 정보를 빠르게 알 수 있다 \\
\cline { 2 - 4 } & 블로그 & - 쉽게 찾을 수 있고 다른 SNS보다 상대적으로 구체적인 정보이다 \\
\cline { 2 - 4 } & 유튜브 & - 사람들이 실제 경험을 촬영하여 올려서 이해하기 쉽다 \\
\hline \multirow{4}{*}{ 웹사이트 } & $\begin{array}{c}\text { 서울나비, } \\
\text { 부산나비 }\end{array}$ & - 신뢰도가 높고 지금까지 몰랐던 정보와 접근법을 확실하게 알려준다 \\
\cline { 2 - 4 } & DAVE'S ESL & - 외국인들이 쓰는 웹사이트여서 실제 경험에 대해 소통할 수 있는 공간이다 \\
\hline \multirow{2}{*}{ 구글 } & - 편리하다 \\
\hline
\end{tabular}




\section{3) 한국 방문 전 필요한 정보 획득 시 어려운 점}

- 한국 방문 전, 외국인들은 교통수단, 음식점, 숙박, 관광지에 관한 정보를 검색 하고, 기타 필요한 정보로는 항공권, 치안, 환율 등이 있음

- 정보획득의 어려운 점은 대부분 의사소통과 잘못된 정보로 나타남

〈표 3-12〉 한국 방문 전 필요한 정보와 정보 획득시 어려운 점

\begin{tabular}{c|l}
\hline 필요한 정보 & \multicolumn{1}{c}{ 어려운 점 } \\
\hline 교통수단 & $\begin{array}{l}- \text { 한글을 모르는 사람이면 지도만으로는 접근하기 어렵다 } \\
- \text { 영어로 된 주소를 구글에 검색하면 잘못된 위치와 정보가 나온다 }\end{array}$ \\
\hline \multirow{2}{*}{ 음식점 } & $\begin{array}{l}- \text { 리뷰는 많지만 대부분 신뢰도가 낮은 정보이다 } \\
- \text { 현지 사람들이 선호하는 맛집 정보를 찾기가 힘들다 } \\
- \text { 소개가 한국어로 되어있어 외국인이 찾기 힘들다 }\end{array}$ \\
\hline 숙박 & - 호텔 예약할 때 궁금한 점이 있으면 전화해서 알 수 있지만, 외국어는 언어소통이 안 된다 \\
\hline 관광지 & - 한국의 새로운 관광지를 가고 싶지만, 후기가 없고 한국어도 모르면 어렵다 \\
\hline 기타 & - 서울 같은 큰 도시도 정보가 많이 부족하다 \\
\hline
\end{tabular}

\section{다. 항공사 이용}

1) 최근 입/출국시 이용한 항공사와 그 이유

- 김해공항 이용객이 최근 입/출국시 이용한 항공사는 아시아나, 일본항공, 중 화항공 등으로 나타남

- 아시아나를 선택한 이유로는 좌석이 편하고 직항노선이 있어서이며, 그 외 항 공사의 경우 대부분 가격이 저렴해서, 무료 수하물 중량이 커서, 시간대가 좋 아서 등으로 나타남

〈표 3-13〉 최근 입/출국시 이용한 항공사

\begin{tabular}{c|c}
\hline 국적 & 내용 \\
\hline 일본 & 에어부산, 아시아나 \\
\hline 중국 & 일본항공, 대한항공, 아시아나 \\
\hline 대만 & 중화항공 \\
\hline 영어권 & 진에어, 일본항공, 아메리칸항공 \\
\hline 기타 & 타이항공, 아시아나 \\
\hline
\end{tabular}


〈표 3-14〉 해당 항공사를 이용한 이유

\begin{tabular}{c|l}
\hline 구분 & \multicolumn{1}{c}{ 내용 } \\
\hline 아시아나 & - 좌석이 편하고 인천까지 직항으로 올 수 있다 \\
\hline 일본항공 & - 가격이 저렴하다 \\
\hline 중화항공 & - 무료 수하물 중량이 크다 \\
\hline 기타 & - 시간대가 좋아서 \\
\hline
\end{tabular}

\section{2) 이용해 본 항공사별 장단점}

- 대한항공, 아시아나 등 한국 항공사는 서비스가 좋다고 평가하였으며, 중화 항공, 동방항공 등 중국 항공사는 수하물 중량이 크다는 점을 장점으로 많이 언급함

\section{〈표 3-15〉 이용해본 항공사별 장단점}

\begin{tabular}{|c|c|c|}
\hline 구분 & 장점 & 단점 \\
\hline 대한항공 & $\begin{array}{l}\text { - 모든 직원들이 믿을 수 없을 정도로 프 } \\
\text { 로페셔널하다 }\end{array}$ & - 기내 땅콩 제공이 중단됐다 \\
\hline 아시아나 & $\begin{array}{l}\text { - 신뢰도가 높고 좌석도 편하고 서비스가 } \\
\text { 좋다 }\end{array}$ & - 항공권이 비싸다 \\
\hline 진에어 & - 항공권이 저렴하다 & - 인터넷 예약 시 오류가 여러 번 생겼다 \\
\hline 제주항공 & - 항공권이 저렴하다 & $\begin{array}{l}\text { - 좋은 시간대가 없고 지연이 많다 } \\
\text { - 좌석 공간이 좁다 }\end{array}$ \\
\hline 에어부산 & - 좌석 공간이 크다 & $\begin{array}{l}\text { - 기내식이 취소되었고 수하물 중량도 줄 } \\
\text { 어들었다 }\end{array}$ \\
\hline 티웨이 & - 좌석이 편하고 서비스가 좋다 & - \\
\hline 일본항공 & - 서비스가 좋고 기내식이 맛있다 & - 특색 없이 평범하다 \\
\hline 중화항공 & - 수하물 중량이 크다 & $\begin{array}{l}\text { - 수하물 분실이 잦아서 많은 사람들이 } \\
\text { 클레임을 건다 } \\
\text { - 항공권이 비싸다 }\end{array}$ \\
\hline 동방항공 & - 수하물 중량이 크다 & $\begin{array}{l}\text { - 대기시간이 길고 좌석이 불편하다 } \\
\text { - 이/착륙할 때 소음이 심하다 }\end{array}$ \\
\hline 남방항공 & - 수하물 중량이 크다 & - 기내식이 너무 간단하다 \\
\hline 타이거항공 & $\begin{array}{l}\text { - 항공권이 저렴하다 } \\
\text { - 시간대가 좋고 면세품을 많이 판다 }\end{array}$ & - 좌석 공간이 좁다 \\
\hline 에어아시아 & - & - 서비스가 좋지 않다 \\
\hline 아메리칸항공 & - & $\begin{array}{l}\text { - 승무원이 전문적이지 않고 친절하지 않다 } \\
\text { - 아시아계 사람을 무시한다 }\end{array}$ \\
\hline
\end{tabular}




\section{라. 공항시설 및 서비스}

1) 공항시설 및 서비스에 대한 평가

- 공항에서 식당, 카페, 와이파이 대여소, 면세점, 은행 등을 많이 이용하고, 그 외에는 셔틀트레인, 택시, 셀프체크인, 약국, SIM카드 구매, 수화물 포장 기계 등을 이용함

- 전반적으로 만족스럽지만 각 시설마다 다소 미흡한 점이 있음

〈표 3-16〉 공항시설 및 서비스에 대한 평가

\begin{tabular}{c|l}
\hline 구분 & \multicolumn{1}{c}{ 평가 } \\
\hline 식당, 카페 & - 김해공항 2층에는 식당이 많지만, 출국장 내에는 식당이 별로 없다 \\
\hline 와이파이 대여소 & $\begin{array}{l}\text { - 친절하게 설명을 잘 해주어 좋았다 } \\
- \text { 기계 작동이 복불복이다 }\end{array}$ \\
\hline 면세점 & - 규모가 작고 제품 종류가 적다 \\
\hline 은행 & - 시간이 정해져 있어 야간 항공편을 탔을 때는 이용할 수 없다 \\
\hline 편의점 & - 상품의 종류가 많아지고 매장이 넓어져서 매우 편리했다 \\
\hline
\end{tabular}

2) 외국인 관광객을 위해 개선/추가되어야 할 점

- 외국인 관광객을 위하여 리무진 증편, 언어 문제가 가장 개선되어야 하며, 라 운지, 문화체험 등 기다리는 시간을 활용할 수 있는 시설이 추가 되었으면 함

- 그 외에 김해공항은 좋은 시설을 갖추고 있지만, 김해공항에 대해 외국인이 잘 알지 못하므로 홍보의 필요성도 언급하고 있음

〈표 3-17〉 김해공항 이용 외국인 관광객을 위한 개선점

\begin{tabular}{|c|c|c|}
\hline \multicolumn{2}{|c|}{ 구분 } & 내용 \\
\hline \multirow{4}{*}{$\begin{array}{l}\text { 교통 } \\
\text { 수단 }\end{array}$} & 택시 & $\begin{array}{l}\text { - 택시는 요금을 높게 부르는 등 언어소통이 안 되어 불안감이 있기 때문에 외국 } \\
\text { 인 관광객이 더 편하게 이용할 수 있도록 관리해야한다 }\end{array}$ \\
\hline & 리무진 & $\begin{array}{l}\text { - 김해공항에서 관광지로 가는 리무진 증설이 필요하다 } \\
\text { - 승차해야 할 위치를 안내표시판에 더 정확하게 표시해야한다 }\end{array}$ \\
\hline & 경전철 & - 경전철 안내서 제작이 필요하다 \\
\hline & $\begin{array}{c}\text { 무료 } \\
\text { 셔틀버스 }\end{array}$ & - 서면이나 해운대 등 주요 지역들로 노선을 생성해야한다 \\
\hline \multicolumn{2}{|c|}{ 언어 } & - 외국어가 가능한 직원들로 배치해야한다 \\
\hline
\end{tabular}




\begin{tabular}{|c|c|}
\hline 구분 & 내용 \\
\hline 음식 & - 특정 종교를 위한 음식점을 개설해야한다 \\
\hline 환전 & - 24시간 운영하는 환전소가 필요하다 \\
\hline 시설 & $\begin{array}{l}\text { - 충전장소, 대합실, 라운지를 추가해야한다 } \\
\text { - 문화체험시설과 같이 기다리는 시간을 즐길 수 있는 시설을 개설해야한다 } \\
\text { - 기도실 개설이 필요하다 }\end{array}$ \\
\hline 기타 & $\begin{array}{l}\text { - 상품 구매시 바로 택스프리 할 수 있게 개선되어야한다 } \\
\text { - 인천공항에서 환승해서 올 수 있는 항공편을 증설해야한다 } \\
\text { - 김해공항 시설 자체 홍보가 필요하다 }\end{array}$ \\
\hline
\end{tabular}

\section{마. 주변관광지 정보}

1) 공항에서 주변 관광지로 갈 경우 필요한 정보

- 김해공항에서 주변 관광지 이동 시 가장 적절한 교통수단과 관광지의 운영시 간, 이벤트 등에 대한 정보를 가장 필요로 함

〈표 3-18〉 공항에서 주변 관광지를 방문시 가장 필요한 정보

\begin{tabular}{c|c}
\hline 구분 & 내용 \\
\hline 교통정보 & - 버스 스케줄, 가장 적절한 교통수단 (택시 지불수단, 길에 대한 정보 등) \\
\hline 관광지 & - 관광지의 운영시간, 체험프로그램 및 이벤트 \\
\hline
\end{tabular}

2) 관광지 정보 획득시 개선사항

- 관광지 정보를 얻을 때 언어문제가 가장 크고, 그 외에는 가짜 리뷰로 인하여 실제 맛집을 찾기 어려움

- 김해공항 내 눈에 잘 띄는 곳에 다양한 언어의 여행안내서, 관광지 광고판을 배치해 외국인들이 쉽게 정보를 접할 수 있도록 개선이 필요함

〈표 3-19〉 관광지 정보획득의 어려운 점

\begin{tabular}{c|l}
\hline 구분 & \multicolumn{1}{c}{ 내용 } \\
\hline 언어 & $\begin{array}{l}- \text { 리무진 버스 정류장 표시판에 외국어 표시가 별로 없다 } \\
- \text { 언어문제로 관광지의 운영시간이나 리뷰를 확인하기 어렵다 }\end{array}$ \\
\hline 음식점 & - 가짜 리뷰나 추천으로 실제 맛집을 찾기 힘들다 \\
\hline
\end{tabular}


〈표 3-20〉 관광지 정보획득 개선사항

\begin{tabular}{|c|c|}
\hline 구분 & 내용 \\
\hline 교통정보 & $\begin{array}{l}\text { - 지하철 노선도, 버스 탑승 방식 등 소개가 필요하다 } \\
\text { - 교통수단 안내판에 다양한 외국어로 표시해야한다 }\end{array}$ \\
\hline 관광지 & $\begin{array}{l}\text { - 추천 관광지, 음식점 등 여행 안내서를 가장 눈에 잘 띄는 곳에 배치되어야한다 } \\
\text { - 공항에서 여행정보를 어디에서 얻을 수 있는지 방송해야한다 } \\
\text { - 도시의 대표적인 관광지 광고판을 눈에 띄게 설치해야한다 }\end{array}$ \\
\hline 기타 & $\begin{array}{l}\text { - 국내에서 자주 사용하는 여행앱이나 온라인 여행사에서 한국에 대한 정보 추가가 } \\
\text { 필요하다 }\end{array}$ \\
\hline
\end{tabular}

\section{바. 교통수단}

1) 이용한 교통수단에 대한 평가

- 교통수단은 배차간격이 짧고, 빠른 지하철과 편안하고 빠른 리무진 버스의 만 족도가 높음

- 반면, 택시의 경우 의사소통이 어렵고, 사기를 당할 우려가 있으며, 버스의 경 우 외국인을 위한 안내(영어 등)가 부족한 것으로 나타남

〈표 3-21〉이용한 교통수단에 대한 평가

\begin{tabular}{|c|c|}
\hline 구분 & 평가 \\
\hline 택시 & $\begin{array}{l}\text { - 제일 빠르고 편리해서 만족스럽다 } \\
\text { - 비싸고 의사소통 문제로 목적지를 설명하기 힘들다 } \\
\text { - 한국 돈을 잘 모르는 외국인은 사기를 당할 수 있다 }\end{array}$ \\
\hline 지하철 & $\begin{array}{l}\text { - 깨끗하고 빨라서 만족했다 } \\
\text { - 지하철 스케줄 보기가 편하며, 자주 오고 정시에 온다 } \\
\text { - 공항과 연결되어 있지 않아 나가서 } 10 \text { 분 정도 걸어야 한다 } \\
\text { - 사상역에서 환승도 야외로 나가야 해서 힘들다 } \\
\text { - 엘리베이터도 작고 낡아서 짐이 많을 때 불편하다 }\end{array}$ \\
\hline 리무진 버스 & $\begin{array}{l}\text { - 운전기사가 짐을 옮겨주고 친절하게 안전운전 해주셔서 좋다 } \\
\text { - 좌석이 커서 매우 편안했다 } \\
\text { - 멈추는 정류장이 많지 않아 지하철보다 빠르고 택시를 이용했을 때보다 저렴하다 }\end{array}$ \\
\hline 버스 & $\begin{array}{l}\text { - 갑자기 시간이 바뀌고 놓치면 다시 기다려야 한다 } \\
\text { - 지하철은 목적지나, 지도에 영어가 있는데, 버스에선 노선도나 목적지들이 다 한국어 } \\
\text { 로 되어있거나 한국어로 방송하고, 버스를 어디서 타야 내가 가려는 방향으로 갈 수 } \\
\text { 있는지 표시가 되어 있지 않아 힘들다 }\end{array}$ \\
\hline
\end{tabular}




\section{2) 공항 접근성 및 연계교통 관련 개선점}

- 공항에서 이동하기 제일 효율적인 리무진에 관한 개선사항이 많았으며, 부산 시내의 유명 관광지로 갈 수 있는 직통 노선 많아지길 원하는 것으로 나타남

〈표 3-22〉 공항 접근성 및 연계교통 관련 개선점

\begin{tabular}{c|l}
\hline 구분 & \multicolumn{1}{c}{ 내용 } \\
\hline 지하철 & - 공항과 지하철 타는 곳까지 실내로 연결되면 좋겠다 \\
\hline \multirow{3}{*}{ 리무진 버스 } & - 리무진 버스 운행 횟수를 증가해야한다 \\
& - 김해공항에서 관광지로 가는 버스를 개설해야한다 \\
& - 해운대나 부산대, 서면이나 경성대 직통 개설이 필요하다 \\
& - 리무진이 제일 효율적인 수단으로 외국인에게 홍보 해야한다 (정류장 위치, 시간표 등) \\
\hline \multirow{2}{*}{ 기타 } & - 외국인들의 자동차 렌트를 위한 서비스를 제공해야한다 \\
& -24 시간 환전소를 운영하여 외국인들이 현지 대중교통을 이용하도록 유도해야한다 \\
\hline
\end{tabular}

\section{사. 공항 인근 지역 여행}

\section{1) 공항 인근 지역을 여행할 때 가장 좋았던 점}

- 김해공항 이용객들은 대부분 해운대, 광안리, 서면, 자갈치 시장 등 부산의 유 명한 관광지를 방문했고, 그 외에도 거제도, 창원, 울산을 방문함

- 외국인들은 대중교통에 대한 만족도가 매우 높았으며, 관광지의 경치 및 분위 기를 좋아함

〈표 3-23〉 공항 인근 지역 여행시 가장 좋았던 점

\begin{tabular}{c|l}
\hline 구분 & \multicolumn{1}{c}{ 내용 } \\
\hline \multirow{5}{*}{ 교통 } & - 목적지 인근까지 가는 교통수단이 있었다 \\
& - 버스 기사의 태도가 친절해서 좋았다 \\
& - 지하철을 타면 빨리 도착할 수 있어서 편리하다 \\
& - 한국은 대중교통으로 여행하기 좋은 나라인 것 같다 \\
\hline \multirow{5}{*}{ 관광 } & - 음식이 맛있다 \\
& - 관광지에 외국어 안내 표지나 메뉴판이 있었다 \\
& - 전소가 있거나 쇼핑, 음식 등 여러 가지가 좋았다 \\
& - 여러 가지 관광거리가 있어서 즐거웠다 \\
\hline \multirow{5}{*}{ 분위기 } & - 대저생태공원 경치가 아름다웠다. \\
& - 템플스테이, 섬 하이킹, 남해도 가고 그곳에서 4륜차를 타고 섬을 한 바퀴 돌았는데 \\
& 그때 너무 행복했다 \\
& - 가야 테마파크의 분위기가 좋았다. 갔을 때 그 웅장함과 분위기에 마음이 편안해졌 \\
& 고, 굉장히 아름다웠다 \\
\hline
\end{tabular}




\section{2) 공항 인근 여행할 때 가장 불편했던 점}

- 의사소통에 대한 문제가 가장 크며, 이로 인하여 관광에 대한 정보를 얻기 힘듦

- 일부 관광지의 경우 대중교통 정보가 부족하여 이에 대한 개선이 필요해 보임

〈표 3-24〉 공항 인근 지역 여행시 가장 불편했던 점

\begin{tabular}{c|l}
\hline 구분 & \multicolumn{1}{c}{ 내용 } \\
\hline \multirow{2}{*}{ 교통 } & $\begin{array}{l}\text { - 감천문화마을은 작은 마을버스여서 사람이 많을 때는 불편하다 } \\
- \text { 대저생태공원 근처에서 택시를 타기 어렵다 } \\
- \text { 외국인에게는 방향을 찾기 어렵고 버스정류장 위치도 찾기 어렵다 }\end{array}$ \\
\hline 언어 & $\begin{array}{l}- \text { 부산에서 영어를 할 수 있는 사람이 적어서 의사소통이 불편하다 } \\
\text { - 언어소통이 힘들어서 현지 사람들에게 교통정보를 얻기 힘들다 }\end{array}$ \\
\hline 숙박 & $\begin{array}{l}- \text { 호텔에 목욕가운이나 샴푸나 린스, 드라이기가 없어 불편하다 } \\
- \text { 여행비용에서 숙박시설 비용이 많이 차지한다 }\end{array}$ \\
\hline 기타 & $\begin{array}{l}- \text { 김해공항에서 바로 여행하기엔 짐이 많았는데 보관할 장소가 없다 } \\
\text { 인근 지역의 이름이 너무 비슷해서 분별이 어렵다(김해/남해/거제) }\end{array}$ \\
\hline
\end{tabular}

\section{아. 국내 타 공항과의 비교}

\section{1) 국내 타 공항과 비교했을 경우, 장/단점}

- 김해공항은 규모가 작아서 공항 내에서 이동하기 편리하고 출입국 절차가 빠 르지만, 면세점도 작고 시간을 보낼만한 시설이 별로 없음

- 반면, 인천공항이나 김포공항은 비행기도 많고 시설이 좋지만, 사람이 많아 복잡하며 대기시간이 김

〈표 3-25〉 국내 타 공항과 비교시 장/단점

\begin{tabular}{|c|c|c|}
\hline \multicolumn{2}{|c|}{ 구분 } & 내용 \\
\hline \multirow[t]{2}{*}{ 김해공항 } & 장점 & $\begin{array}{l}\text { - 공항이 작아서 출입국 절차와 택스프리가 빠르다 } \\
\text { - 시내까지 거리가 다른 나라에 비해서 가까운 편이다 } \\
\text { - 김포공항은 붐비고 길 찾기 헷갈렸지만 김해공항은 깔끔하고 간단했다 } \\
\text { - 김포공항보다 지하철이 가까이 있다 } \\
\text { - 인천공항에 비해 국제선과 국내선이 가까이 있고 영어로 셀프체크인 가능한 기 } \\
\text { 계도 있다 }\end{array}$ \\
\hline & 단점 & $\begin{array}{l}\text { - 면세점이 두 개만 있는 것 같고 매장도 작다 } \\
\text { - 너무 규모가 작아서 시간을 보낼만한 무언가가 없다 } \\
\text { - 다른 공항보다 여러 나라로 가는 직항 비행기가 없다 }\end{array}$ \\
\hline
\end{tabular}




\begin{tabular}{|c|c|c|}
\hline \multicolumn{2}{|c|}{ 구분 } & 내용 \\
\hline \multirow[t]{2}{*}{ 인천공항 } & 장점 & $\begin{array}{l}\text { - 직항노선이 많고 비행기도 } 10 \text { 분, } 15 \text { 분 간격으로 매우 많다 } \\
\text { - 서울역에서 미리 짐을 맡기고 체크인 할 수 있어 좋다 } \\
\text { - 면세점, 식당, 카페, 셀프체크인이 많다 } \\
\text { - 공간이 넓고 화장실이 깨끗하다 } \\
\text { - 문화체험이 가능해서 기다리는 시간을 보내기 좋고 마지막까지 여행을 즐길 수 } \\
\text { 있는 시설이 많아서 좋다 } \\
\text { - 교통수단이 다양해서 인천에서 김해로 환승할 때도 편리하다 }\end{array}$ \\
\hline & 단점 & $\begin{array}{l}\text { - 사람이 많아서 붐비고 대기하는 줄이 길다 } \\
\text { - 가격이 비싸고 넓어서 걷기 힘들다 } \\
\text { - 공항에 중국어를 할 수 있는 직원이 별로 없어 의사소통이 힘들다 } \\
\text { - 공항에서 실수가 생기면 바로 처리해줘야 하는데 서로 책임을 전가한다 }\end{array}$ \\
\hline \multirow[b]{2}{*}{ 김포공항 } & 장점 & $\begin{array}{l}\text { - 서울과 가까워서 좋다 } \\
\text { - 지하철이 근처에 있다 }\end{array}$ \\
\hline & 단점 & $\begin{array}{l}\text { - 지하철을 타기위해 이동하는 거리가 멀다 } \\
\text { - 식당이 그다지 없고 가격이 비싸다 } \\
\text { - 자동문도 많고 나가는 게이트가 많아서 나가는 헷갈렸고, 공항에서 출발하는 리 } \\
\text { 무진 표지도 읽을 줄 몰라서 버스타기 힘들다 }\end{array}$ \\
\hline
\end{tabular}

\section{2) 외국인 관광객을 지방으로 유치하기 위해 필요한 정책}

- 김해공항 이용객이 대기할 장소나 의자가 더 많아야 하며, 대기하면서 시간을 보낼 수 있는 시설이 필요

- 외국인이 체험할 수 있는 이벤트, 축제 등 관광코스 등이 필요함

〈표 3-26〉 외국인을 지방으로 유치하기 위해 필요한 정책

\begin{tabular}{|c|c|}
\hline 구분 & 내용 \\
\hline 교통 & $\begin{array}{l}\text { - 김해에서 지방으로 가는 버스를 공항 밖에서 바로 탈 수 있어야한다 } \\
\text { - 김해에서 직접 가는 노선이 생긴다면 접근성이 좋아져서 더 많이 이용할 것이다 } \\
\text { - 시내까지 가는 대중교통을 좀 더 알기 쉽게 표기해야한다 }\end{array}$ \\
\hline 시설 & $\begin{array}{l}\text { - 식당이나 카페가 더 늘었으면 좋겠다 } \\
\text { - 공항에 앉을 수 있는 좌석은 전보다 늘었지만, 더 늘었으면 좋겠다 } \\
\text { - 사람이 많아서 좌석이 없고 공항에서 시간을 보낼 수 있는 시설이 더 생기면 좋을 것 } \\
\text { 같다 } \\
\text { - 주변에 관광할 장소, 맛있는 가게, 의자, TV 등 쉴 수 있는 공간을 좀 더 늘리면 좋을 } \\
\text { 것 같다 }\end{array}$ \\
\hline 관광 & $\begin{array}{l}\text { - 유명한 관광코스, 재밌는 투어가 생기면 김해공항 이용객은 증가할 것이다 } \\
\text { - 한국에서는 체험할 수 있는 게 별로 없다 } \\
\text { - 해운대도 아름답지만, 아무것도 없고 제대로 이용되지 않는다 }\end{array}$ \\
\hline 기타 & - 국제 항공편이 너무 적다 \\
\hline
\end{tabular}




\section{2. 무안공항 이용객 심층면접조사}

\section{가. 응답자 특성}

무안공항 이용 경험이 있는 외국인 의견 수렴을 위한 심층면접 조사의 응답자 특 성은 다음과 같다.

〈표 3-27〉 무안공항 심층면접조사 응답자

\begin{tabular}{c|c|c|c|c}
\hline 이름 & 국적 & 성별 & 출생년도 & 직업 \\
\hline Chen $\times \times \times$ & 대만 & 남자 & 1991년 & 회사원 \\
\hline Chen $\times \times \times$ & 대만 & 여자 & 1983년 & 번역 \\
\hline$\times \times \times$ 나오츠 & 일본 & 여자 & 1997년 & 대학생 \\
\hline 오오야마 $\times \times \times$ & 일본 & 여자 & 1968년 & $\begin{array}{c}\text { 프리랜서 강사, } \\
\text { 통역 }\end{array}$ \\
\hline 간 $\times \times \times$ & 중국 & 여자 & 1996년 & 대학원생 \\
\hline
\end{tabular}

\section{나. 한국 여행 정보 획득}

1) 해외 현지에서 한국 여행 정보 획득 경로

- 무안공항 이용객 중 일본이나 대만 사람들은 대체로 해외 현지에서 사용하는 블로그를 통해 정보를 얻음

- 중국 사람들은 주로 웨이보와 같은 SNS나 여행 관련 앱을 통해 정보를 얻고 있음

〈표 3-28〉 해외 현지에서 한국 여행 정보를 얻은 경로

\begin{tabular}{c|l}
\hline 국적 & \multicolumn{1}{c}{ 내용 } \\
\hline 일본 & - 블로그, 여행사 사이트, YAHOO(포털사이트) \\
\hline 중국 & - 웨이보(SNS), 소홍서(SNS) \\
\hline 대만 & - 블로그, 구글, 아고다 \\
\hline
\end{tabular}




\section{2) 해당 경로를 사용한 이유}

- 정보를 빠르게 공유할 수 있고 실제 경험을 구체적으로 알 수 있는 블로그를 많이 사용하고 있으며, 특히 인지도와 지명도가 높은 SNS를 통해 다수의 이 용자로부터 많은 정보를 얻고자 함

- 구글은 정보량이 많아서 외국인들이 정보를 얻기 매우 편리함

〈표 3-29〉해당 경로를 사용한 이유

\begin{tabular}{|c|c|c|}
\hline \multicolumn{2}{|c|}{ 구분 } & 이유 \\
\hline \multirow{3}{*}{ SNS } & 블로그 & - 한국 여행 후기와 관광지 환경, 식당 정보를 알 수 있다 \\
\hline & 웨이보 & - 중국에서 지명도가 높다 \\
\hline & 소홍서 & - 중국에서 지명도가 높고 웨이보보다 더 체계적이다 \\
\hline \multirow{2}{*}{ 웹사이트 } & $\begin{array}{l}\text { YAHOO의 } \\
\text { 4TRAVEL }\end{array}$ & - 실제 한국을 방문했던 분이 알기 쉽게 작성해서 좋다 \\
\hline & 아고다 & $\begin{array}{l}\text { - 가격을 비교할 수 있고 혜택이 많다 } \\
\text { - 언어문제가 없다 }\end{array}$ \\
\hline \multicolumn{2}{|c|}{ 구글 } & - 정보량이 많아 정보를 쉽게 얻을 수 있다 \\
\hline
\end{tabular}

\section{3) 한국 방문 전 필요한 정보 획득시 어려운 점}

- 한국 방문 전, 교통수단과 관광지에 관한 정보를 검색하며, 기타 필요한 정보 로는 호텔, 쇼핑 및 브랜드 매장 위치 등이 있음

- 정보 수집시 대도시와 중소도시 간의 정보 격차와 언어문제가 가장 큰 것으로 나타남

〈표 3-30〉 한국 방문 전 필요한 정보 획득시 어려운 점

\begin{tabular}{c|l}
\hline 필요한 정보 & \multicolumn{1}{c}{ 어려운 점 } \\
\hline 교통수단 & $\begin{array}{l}\text { - 중소도시에 대한 정보를 찾기가 어렵고 버스 시간표나 공식 웹사이트에 외국어 } \\
\text { 를 지원하지 않아 어렵다 }\end{array}$ \\
\hline 관광지 & $\begin{array}{l}\text { - 사람들이 많이 가지 않는 중소도시는 여행 후기가 매우 적고 드물어 정보를 } \\
\text { 찾기 어렵다 }\end{array}$ \\
\hline 기타(호텔, 쇼핑) & \multicolumn{1}{|c}{-} \\
\hline
\end{tabular}




\section{다, 항공사 이용}

1) 최근 입/출국시 이용한 항공사와 그 이유

- 무안공항 이용객이 최근 입/출국시 이용한 항공사는 제주항공, 동방항공이며, 일본과 대만에서 오는 무안행 항공편은 제주항공밖에 없기 때문에 이용한 것 으로 나타남

〈표 3-31〉 최근 입/출국시 이용한 항공사

\begin{tabular}{l|lc}
\hline 국적 & & 내용 \\
\hline 일본 & - 제주항공 \\
\hline 중국 & - 동방항공 \\
\hline 대만 & - 제주항공 & \\
\hline
\end{tabular}

〈표 3-32〉 해당 항공사를 이용한 이유

\begin{tabular}{c|c}
\hline 구분 & \multicolumn{1}{c}{ 내용 } \\
\hline 제주항공 & - 일본과 대만에서 가는 무안행 항공편으로 유일 \\
\hline 동방항공 & - 비행기 표가 많고 시간이 적절 \\
\hline
\end{tabular}

\section{2) 이용해 본 항공사별 장단점}

- 대한항공, 아시아나는 서비스가 좋다는 점을, 동방항공, 태국항공은 항공권이 저 렴하고 비행기를 이용할 수 있는 시간이 적절하다는 점을 장점으로 많이 언급함

〈표 3-33〉이용해본 항공사별 장단점

\begin{tabular}{c|l|c}
\hline 구분 & \multicolumn{1}{|c}{ 장점 } & \multicolumn{1}{|c}{ 단점 } \\
\hline 대한항공 & $\begin{array}{l}\text { - 직원들이 전문적이고 서비스가 좋으며 항공 } \\
\text { 기가 새 거 같아 안심적이다 }\end{array}$ & $\begin{array}{l}\text { 항공권이 비싸고 대만에서 무안까지 직 } \\
\text { 행 노선이 없다 }\end{array}$ \\
\hline 아시아나 & - 수하물 중량이 크고 직원들이 친절하다 & - 항공권이 비싸다 \\
\hline 제주항공 & - 항공권이 저렴하고 국제항공노선이 다양하다 & $\begin{array}{l}- \text { 기내식이 없고 수하물 중량이 적어 추가 } \\
\text { 비용을 지불해야 한다 }\end{array}$ \\
\hline 티웨이 & - 항공권이 저렴하다 & $\begin{array}{l}\text { 수하물 중량이 적어 추가비용을 지불해 } \\
\text { 야 한다 }\end{array}$ \\
\hline
\end{tabular}




\begin{tabular}{c|c|c}
\hline 구분 & 장점 & 단점 \\
\hline 동방항공 & - 출발시간이 적절해 이용하기 편리하다 & - 좌석 공간이 좁다 \\
\hline 태국항공 & - 항공권이 저렴하고 이동시간도 적절하다 & - \\
\hline 케세이퍼시픽 & - & $\begin{array}{l}\text { - 시간대가 다양하지 않고 항공권도 생각 } \\
\text { 보다 저렴하지 않다 }\end{array}$ \\
\hline
\end{tabular}

\section{라. 공항시설 및 서비스}

\section{1) 공항시설 및 서비스에 대한 평가}

- 이용객들은 공항에서 식당, 관광안내센터, 편의점을 주로 이용하고 있음

- 전반적으로 만족스럽고 편리하나 외국어 지원이 부족해 불편함이 있음

〈표 3-34〉 공항시설 및 서비스에 대한 평가

\begin{tabular}{c|c}
\hline 구분 & 평가 \\
\hline 식당 & - 음식은 맛있지만, 외국어가 없어 메뉴 선택이 어렵다 \\
\hline 관광안내센터 & - 이용방법에 대해 친절하게 알려 주셔서 좋았다 \\
\hline 편의점 & - 매장이 크고 멀티 플러그 등의 필요한 물품이 잘 구비되어 있다 \\
\hline
\end{tabular}

\section{2) 외국인 관광객을 위해 개선/추가되어야 할 점}

- 외국인들은 한국의 공항이라 하면 인천공항의 이미지가 있어서 무안공항에 여 러 편의시설이 없는 것을 곤란해 함

- 약국, 와이파이 렌탈, 짐 보관소 등 외국인 관광객을 위한 편의시설이 추가되어야 함

〈표 3-35〉 무안공항 이용 외국인 관광객을 위한 개선점

\begin{tabular}{|c|c|}
\hline 구분 & 평가 \\
\hline 교통 & $\begin{array}{l}\text { - 무안공항은 도착하면 반드시 버스를 타야 하는데 버스정류장이 어디 있는지, 시간표 등을 알 } \\
\text { 기 어려우므로 알기 쉽게 영어로 표기해야한다 } \\
\text { - 현재 교통수단 안내표지에 대한 개선이 필요하다 }\end{array}$ \\
\hline 시설 & $\begin{array}{l}\text { - 약국, SIM 카드 매장, 와이파이 렌탈, 한국여행 기념품 가게를 추가해야한다 } \\
\text { - 환전소가 무안에서 출발하는 비행기 편에 맞춰서만 운영되는 점을 개선해야한다 } \\
\text { - 환승 대기시간에 이용객들이 관광을 위해 짐을 맡길 장소나 락커 설치가 필요하다 }\end{array}$ \\
\hline
\end{tabular}




\section{3) 공항 이용 시 주변 도시나 지역 관광지에 대한 정보 획득}

- 무안공항 이용객들은 공항에 비치된 안내 책자를 통해 쉽게 관광지 정보를 얻을 수 있었음

〈표 3-36〉 공항 이용 시 주변 도시나 지역 관광지에 대한 정보 획득

\begin{tabular}{c|l}
\hline 구분 & 평가 \\
\hline \multirow{3}{*}{ 정보 획득 } & - 버스 루트가 적힌 지도를 받아 매우 편리했다 \\
& - 광주 시내에서 이 지도를 받을 수 있다면 매우 도움이 될 거라고 생각한다 \\
& - 공항 내부에 관광안내 책자를 비치해 놓아서 여행정보를 쉽게 찾을 수 있다 \\
\hline
\end{tabular}

\section{마. 주변 관광지 정보}

1) 공항에서 주변 관광지로 갈 경우 필요한 정보

- 무안공항은 도심과 떨어져 있기 때문에 교통수단관련 정보가 가장 중요함

〈표 3-37〉 공항에서 주변 관광지를 방문시 가장 필요한 정보

\begin{tabular}{c|l}
\hline 구분 & \multicolumn{1}{c}{ 내용 } \\
\hline 교통정보 & - 버스 매표소, 버스 타는 곳 등 상세한 교통 안내 \\
\hline 기타 & - 맛있는 음식, 주변 여행지 소개 \\
\hline
\end{tabular}

2) 관광지 정보 획득시 개선사항

- 공항에 주변 관광지에 대한 안내가 전혀 없으며, 주변 관광지로 갈 때 필요한 교통정보와 관광지 정보가 필요한 것으로 나타남

- 공항 내 대기장소에 주변 관광지에 대한 홍보 영상 등을 제공하여 주변 관광 지에 대한 안내 및 유치를 하는 노력이 필요함

〈표 3-38〉 관광지 정보획득의 어려운 점

\begin{tabular}{|c|c|}
\hline 구분 & 내용 \\
\hline 어려운 점 & $\begin{array}{l}\text { - 공항에 주변 관광지, 호텔 등에 관한 소개가 전혀 없어 여행정보를 얻기 } \\
\text { 힘들다 } \\
\text { - 공항 위치가 외지고 주변에 아무것도 없다 }\end{array}$ \\
\hline
\end{tabular}


〈표 3-39〉 관광지 정보획득 개선사항

\begin{tabular}{c|l}
\hline 구분 & \multicolumn{1}{c}{ 내용 } \\
\hline & - 유명한 호텔까지 가는 버스 루트 추가가 팔요하다 \\
& - 무안공항에 상세한 교통 안내서를 배치해야한다 \\
& - 버스 정류장에서 가까운 지하철역 정보, 근처 관광지 정보가 적힌 팜플렛 제작 \\
& 이 필요하다 \\
& - 현재 운행되는 버스시간과 항공 출발시간 차이가 크므로 도심에서 무안공항으 \\
& 로 오는 버스 시간표를 개선해야한다 \\
& - 도심과 무안공항을 연결하는 지이하철이 있으면 편리할 것이다 \\
\hline \multirow{2}{*}{ 관광지 } & - 입국이나 출국 대기장소에 TV로 주변 여행지 소개를 하면 다음에 한국을 방문 \\
& 하려는 의향이 생기는 사람이 많아질 것이다 \\
\hline 기타 & - 공항 위치가 외지고 주변에 아무것도 없어 공항 내 식당 개설이 필요하다 \\
\hline
\end{tabular}

바. 교통수단

1) 이용한 교통수단에 대한 평가

- 무안공항 이용객들은 대부분 리무진 버스와 택시를 이용하여 이동하고 있으 며, 리무진 버스에 대해 대부분 만족하지만 운행 횟수가 적고 자동화된 발권 시스템이 어려운 점으로 나타남

- 택시는 기사가 불친절하고, 사기를 당한 경험이 있는 등 평이 좋지 않음

〈표 3-40〉이용한 교통수단에 대한 평가

\begin{tabular}{l|l|l}
\hline \multicolumn{2}{|c|}{ 구분 } & \multicolumn{1}{c}{ 평가 } \\
\hline \multirow{3}{*}{ 리무진 버스 } & 장점 & $\begin{array}{l}\text { - 비싸지 않고 환승방법도 불편하지 않다 } \\
- \text { 버스 내리는 곳과 역이 가까워서 알기 쉽고 힘들지 않았다 }\end{array}$ \\
\cline { 2 - 3 } & 단점 & $\begin{array}{l}\text { - 심야에는 버스가 없다 } \\
- \text { 운행횟수가 적다 } \\
- \text { 직원이 외국어를 못하고 특별하게 친절한 느낌을 받지 못했다 } \\
- \text { 티켓 구매가 모두 자동화여서 불편하다 } \\
\text { (카드만 가능, 매표과정이나 순서 복잡) }\end{array}$ \\
\hline \multicolumn{2}{|c|}{ 택시 } & $\begin{array}{l}\text { - 불친절하다 } \\
- \text { 사기를 당했다 }\end{array}$ \\
\hline
\end{tabular}




\section{2) 공항 접근성 및 연계교통 관련 개선점}

- 비행기 도착시간과 리무진 버스 출발시간의 간격 차이가 심해 이를 조정해야 할 필요가 있음

- 버스 좌석이 부족하고, 리무진 버스 배차 간격도 조정해 주었으면 함

〈표 3-41〉 공항 접근성 및 연계교통 관련 개선점

\begin{tabular}{c|c}
\hline 구분 & 내용 \\
\hline 리무진 버스 & - 비행기 시간을 고려해 버스 배차시간 간격 조정이 필요하다 \\
\hline 택시 & - 언어 소통 문제를 개선해야한다 \\
\hline
\end{tabular}

\section{사. 공항 인근 지역 여행}

1) 공항 인근 지역을 여행할 때 가장 좋았던 점

- 무안공항 이용객들은 대부분 광주, 전주, 목포를 방문함

- 공항 인근(광주/전라) 여행 시 음식이 맛있다는 것에 가장 만족하고 있으며, 한국의 전통문화를 직접 체험해보는 것을 좋아함

〈표 3-42〉 공항 인근 지역 여행시 가장 좋았던 점

\begin{tabular}{|c|c|}
\hline 구분 & 내용 \\
\hline 광주 & $\begin{array}{l}\text { - 광주 도심은 맛있는 음식이 많다 } \\
\text { - 1913시장은 전통적이고 맛있는 먹거리도 많아 인기가 많다 } \\
\text { - 터미널에서 전라남도 어디라도 갈 수 있으므로 편리하다 }\end{array}$ \\
\hline 전주 & $\begin{array}{l}\text { - 전주영화종합촬영소가 괜찮았다 } \\
\text { - 한복을 무료로 체험할 수 있고 사진도 찍을 수 있다 } \\
\text { - 비빔밥이 맛있다 }\end{array}$ \\
\hline 목포 & - 해양 케이블카가 괜찮았다 \\
\hline
\end{tabular}


2) 공항 인근 지역 여행시 가장 불편했던 점

- 공항 인근 여행 시 의사소통이 가장 큰 문제점으로 나타나며, 관광지 부족도 문제점으로 나타남

〈표 3-43〉 공항 인근 지역 여행시 가장 불편했던 점

\begin{tabular}{c|l}
\hline 구분 & \multicolumn{1}{c}{ 내용 } \\
\hline \multirow{3}{*}{ 언어 } & $\begin{array}{c}\text { 공항 내 안내판에 외국어 안내가 알기 쉽게 표기되어 있으면 좋겠다 } \\
- \text { 무안공항 인근 도시에 중국어 할 수 있는 사람이 별로 없어서 외국인 여행객들 } \\
\text { 에겐 언어소통이 가장 불편하다 }\end{array}$ \\
\hline 관광지 & $\begin{array}{l}\text { 목포에는 해양 케이블카 이외에 다른 여행지는 특별한 게 없다 } \\
- \text { 쇼핑 번화가라고 해서 갔는데 영업하는 가게도 별로 없었다 }\end{array}$ \\
\hline
\end{tabular}

\section{아. 국내 타 공항과의 비교}

1) 공항에서 출국할 경우 예상되는 어려운 점

- 공항 이용 시 교통에 대한 불편함이 가장 큰 것으로 나타남

- 특히, 아침 일찍 출발하는 비행편의 경우 대중교통을 이용해서 가기 매우 어려 운 것으로 나타남

〈표 3-44〉 무안공항에서 출국할 경우 예상되는 어려운 점

\begin{tabular}{c|c}
\hline 구분 & \multicolumn{1}{|c}{ 내용 } \\
\hline \multirow{2}{*}{ 교통 } & $\begin{array}{l}- \text { 아침 비행기의 경우 버스가 없어 매우 일찍 출발해야한다 } \\
- \text { 가고 싶은 도시(관광지)와 공항과의 거리가 너무 멀다 }\end{array}$ \\
\hline
\end{tabular}

2) 국내 타 공항과 비교시 장/단점

- 무안공항은 규모가 작아서 공항 내에서 이동하기도 편리하고 출입국 절차가 빠르지만, 면세점도 작고 시간을 보낼만한 시설이 별로 없음

- 반면 인천공항은 시설이 다양하고 인근 교통수단도 편리하지만, 사람이 많아 복잡하고 대기시간이 김 
〈표 3-45〉 국내 타 공항과 비교시, 장/단점

\begin{tabular}{|c|c|c|}
\hline \multicolumn{2}{|c|}{ 구분 } & 내용 \\
\hline \multirow[b]{2}{*}{ 무안공항 } & 장점 & $\begin{array}{l}\text { - 전라남도 사람들에게는 접근성이 좋다 } \\
\text { - 무안공항은 작고 사람도 별로 없어서 입국 수속이 빠르고 시간 효율도 높다 }\end{array}$ \\
\hline & 단점 & $\begin{array}{l}\text { - 공항 시설이 부족하다 } \\
\text { - 면세점이 작고 브랜드도 별로 없다 } \\
\text { - 출국 대기시간에 별로 할 일이 없어서 지루하다 }\end{array}$ \\
\hline \multirow{2}{*}{ 인천공항 } & 장점 & $\begin{array}{l}\text { - 인천공항은 식당, 커피점, 편의점 등 시설이 많을 뿐만 아니라 항공노선 및 } \\
\text { 인근 교통수단도 다양하다 } \\
\text { - 직통열차로 도시 중심까지 빠르게 갈 수 있다 } \\
\text { - 공항 및 면세점의 규모가 크고 체험할 거리가 많다 }\end{array}$ \\
\hline & 단점 & $\begin{array}{l}\text { - 사람이 많고 시끄럽다 } \\
\text { - 버스 터미널이 많아서 어디서 타야하는지 어렵다 } \\
\text { - 출국수속할 때 대기시간이 너무 오래 걸린다 }\end{array}$ \\
\hline
\end{tabular}

3) 외국인을 지방으로 유치하기 위해 필요한 정책

- 무안공항에 대한 홍보가 많이 필요하며, 공항 주변의 교통편을 더 확충해 서 공항과 주변 도시 간의 접근성을 높여야 함

- 무안공항 주변 도시의 인지도를 높이기 위해 외국인들이 주로 정보를 얻는 웹사이트나 블로그 등을 활용하여 홍보함으로써 외국인 관광객을 지방으 로 유치해야 함 
〈표 3-46〉 외국인을 지방으로 유치하기 위해 필요한 정책

\begin{tabular}{|c|c|}
\hline 구분 & 내용 \\
\hline 관광지 홍보 & $\begin{array}{l}\text { - 무안공항 주변에 있는 광주, 목포, 여수 등 지방 도시들에 대한 홍보가 필요하다 } \\
\text { - 외국에서도 유명한 한국 TV 예능 프로그램과 협업하여 전라도 내 도시들의 음식이나 } \\
\text { 관광지, 시장 등을 홍보해야 한다 } \\
\text { - 블로그나 여행 관련 웹사이트의 파급력이 크기 때문에 외국의 유명 블로거들을 초 } \\
\text { 대해서 여행 후기를 쓰도록 지원이 필요하다 }\end{array}$ \\
\hline 무안공항 홍보 & $\begin{array}{l}\text { - 무안공항에 대한 홍보 필요가 필요하다(전라도 지역으로 갈 때는 무안공항이 다른 } \\
\text { 공항보다 더 편리) } \\
\text { - 외국인들이 많이 볼 수 있는 블로그나 주로 사용하는 웹사이트, 한국관광공사 공식 } \\
\text { 사이트 등에 무안공항 홍보 내용을 게재해야 한다 }\end{array}$ \\
\hline 교통 & $\begin{array}{l}\text { - 무안공항 이용객에게 공항에서 인근 도시로 갈 때 버스나 택시 등의 교통수단에 할 } \\
\text { 인 프로모션이 필요하다 } \\
\text { - 무안공항에서 출발하는 전라도 시티투어 버스를 개설해야 한다 } \\
\text { - 편리한 교통을 제공하여 공항과 주변 도시와의 접근성을 높여야 한다 } \\
\text { - 외국인 관광객에게 교통정보를 제공해서 이동의 편리성 제고가 필요하다 } \\
\text { - 외국인들에게는 고속버스보다 KTX가 편리하므로 KTX를 타는 방법에 대한 정보를 } \\
\text { 제공해야 한다 }\end{array}$ \\
\hline $\begin{array}{l}\text { 기타 } \\
\text { (시설 등) }\end{array}$ & $\begin{array}{l}\text { - 무안공항 근처에 호텔이 별로 없다 } \\
\text { - 공항 내에 수유실과 정수기 설치가 필요하다 }\end{array}$ \\
\hline
\end{tabular}




\section{제3절 분석결과 및 시사점}

\section{가. 지방공항 이용 외국인 대다수가 개별여행객}

「2019 항공여객 OD 및 특성조사」 분석결과에 따르면, 김해공항을 이용하는 외 국인 관광객 대다수가 '개별여행' 형태였으며, 대만 관광객의 경우 패키지여행이 상 대적으로 많았다. 또한, 한국을 두 번 이상 '재방문'한 경우가 많았으며, 동남아와 구미주 관광객은 여가/위락/휴가 목적으로 여행하는 비율이 높았다. 김해공항을 이 용하는 외국인 관광객은 '부산'을 가장 많이 방문하였으며, 방문지까지 이동 시 택 시나 지하철을 주로 이용하였으나 만족도는 그리 높지 않았다. 김해공항으로 출발 한 지역 역시 '부산'이 가장 많았으며, 공항으로 이동 시 '택시'와 '지하철', '경전철' 등을 많이 이용하고 있는데 평균 소요 시간은 약 42 분으로 나타났다.

\section{나. 저비용항공사(LCC)와 직항노선 주로 이용}

김해공항을 이용하는 외국인 관광객은 'LCC'를 가장 많이 이용하였으며, 그 다음 으로 '외항사', 'FSC'의 순이었다. 응답자 대부분은 '온라인 사이트'를 통해 항공권 을 구매하였는데, 외항사일 경우 비율이 더 높게 나타났다. 해외 출발지에서 '직항 편'으로 한국에 입국한 경우가 대다수였으며, 국내 입국 시에도 '김해공항'을 이용 한 비율이 $89 \%$ 로 나타났다. 한편, 인천공항을 통해 입국한 후 김해공항으로 출국한 비율은 $10 \%$ 정도로 나타났다. 김해공항을 이용하는 외국인 관광객의 최종 목적지 국가는 '일본', '대만', '중국' 등 순이었으며, 환승객인 경우 항공요금이 저렴하고 항공스케줄이 적합했기 때문에 김해공항을 선택하였다는 응답이 많았다.

\section{다. 배후도시 및 주변지역 연계교통 개선 필요}

무안공항을 이용하는 외국인 관광객 역시 대다수가 '개별여행' 형태였으며, 동반 
자 없이 '혼자' 여행하는 경우가 많았다. 김해공항과는 달리 무안공항은 '한국을 처 음으로 방문'한 경우가 $45.4 \%$ 로 높게 나타났다. 무안공항을 이용하는 외국인 관광 객은 '전남'과 '광주' 지역을 가장 많이 방문하였으며, '부산'도 일부 방문한 것으로 나타났다. 방문지까지 이동 시 택시와 시외/고속버스를 주로 이용하였다. 무안공항 으로 출발한 지역은 '광주'와 '전남'이 가장 많았으며, 공항으로 이동 시 '택시'나 '승용차(자가용)', '시외/고속버스' 등을 많이 이용하였는데, 평균 소요 시간이 약 84 분으로 한 시간 이상 오래 걸리는 것으로 나타났다.

\section{라. 환승공항 선택 기준은 항공요금과 항공스케줄}

무안공항을 이용하는 외국인 관광객 중에 'LCC'를 이용한 비율이 약 $89 \%$ 로 압도 적으로 높았으며, 주로 '온라인 사이트'를 통해 항공권을 구매한 것으로 나타났다. 해외 출발지에서 '직항편' 으로 한국에 입국한 경우가 거의 대다수였으며, 국내 입국 시에도 '무안공항'을 이용한 비율이 $86 \%$ 로 나타났다. 한편, 인천공항을 통해 입국 한 후 무안공항으로 출국한 비율은 9\% 정도로 나타났다. 무안공항을 이용하는 외국 인 관광객들의 최종 목적지 국가는 '대만', '일본', '태국' 등 순이었으며, 한국 외 다른 국가를 방문하는 환승객의 경우 항공요금이 저렴하고 항공스케줄이 적합했기 때문에 무안공항을 선택하였다는 응답이 많았다.

\section{마. 외국어 안내정보와 대중교통(버스) 개선 시급}

외국인 대상 개별 심층면접조사 결과에 따르면, 김해공항이나 무안공항과 같은 지방공항을 이용할 때 외국인 관광객들이 느끼는 가장 큰 불편은 언어소통 문제인 것으로 나타났다. 이들은 한국 내 지방여행을 위해 대중교통 및 주요 관광지, 이벤 트, 식당 등에 관한 안내 정보를 가장 필요로 하는 것으로 조사되었다. 공항연계 대 중교통 수단 중에서는 버스가 승차 위치와 운행 방향, 정류장 명칭, 운행 노선, 배차 시간표 등에 관한 외국어 안내 정보가 없어 가장 어려움이 많은 것으로 파악되었다. 지방공항은 인천공항에 비해 규모가 매우 작지만 식당과 카페, 라운지, 대기시설, 면세점, 24 시간 운영 환전소, 약국, 와이파이 렌탈, 수화물 보관소 등 편의시설 및 서비스에 대한 기대를 갖고 있는 것으로 나타났다. 

지방공항을 활용한 지역관광 활성화 방안

제4장

외국 유사사례 분석 



\section{제1절 조사 개요}

본 연구에서는 지방공항을 활용하여 외래관광객 유치 확대를 통해 지역관광을 활 성화하기 위한 해외 주요국의 정책 및 항공 분야와의 협력 사례를 조사하였다. 일본 의 경우, 우리나라와 마찬가지로 인바운드 관광객들이 도쿄-오사카의 골든 루트 (golden route)에 집중되는 문제가 제기되어 왔으나, 최근에 외국인 관광객의 증가 율이 대도시보다 지방부에서 높게 나타나고, 이들 중 약 40\%가 3대 도시권 이외 지역에서 숙박하고 있는 것으로 보고되었다. 일본 정부는 인바운드 관광객의 지방 유치를 위해 관광자원 매력 강화, 관광산업 경쟁력 강화, 관광지원 환경 강화 등의 정책을 적극적으로 실시하고 있다. 특히, 지방공항의 게이트웨이 기능을 강화하고 LCC 취항과 국제선 유치를 지원하고 있어 조사대상 국가로 선정하였다.

우리나라와 함께 동아시아 지역에 속해 있는 태국은 2018년 통계 기준으로 볼 때 인바운드 관광객 수가 세계 9위에 해당하며, 인바운드 관광수입 규모는 세계 4 위를 기록한 바 있다. 태국은 현재 전국에서 운영 중인 공항이 총 39개에 달하며, 수도 방콕의 거점공항 뿐 아니라 푸켓, 치앙마이, 치앙라이, 핫야이 등 지방에 설치 된 공항들이 태국을 방문하는 외국인 관광객들의 입국 관문 역할과 기능을 담당하 고 있다. 특히, 태국은 인바운드 관광산업의 활성화를 위해 관광청 및 공항공사, 지 자체, 항공사, 여행사 등 관련된 다양한 주체들 간의 협력 사업이 활발히 추진되고 있어 이번 조사의 대상국으로 선정하였다.

한편 호주는 국토 면적이 세계에서 6번째로 큰 섬나라로, 국내·외 이동을 위해 항공 교통 서비스에 대한 의존도가 높은 국가들 중에 하나이다. 호주의 수도는 캔버 라이지만 시드니와 멜버른, 브리즈번, 퍼스 등 각 지방에 주요 도시와 관광지가 발 달해있다. 호주의 관광산업은 국가 경제를 지탱하는 수출 산업으로서 외국인 관광 객 1 인당 지출액이 타 국가들에 비해 매우 높은 것으로 보고되고 있다. 호주의 연방 
정부와 지방정부는 인바운드 관광 수요 창출을 위해 다양한 홍보 마케팅 활동을 추 진 중이며, 공항과 철도 등 관광기반 인프라 구축을 위한 투자가 지속적으로 이루어 지고 있어 조사대상 국가로 추가 선정하였다.

일본·태국·호주 등 3 개국을 대상으로 지방공항을 활용한 외래관광객 유치 정책 과제 개발을 위한 시사점을 도출하기 위하여 중점적으로 조사 분석한 항목은 아래 의 표와 같다.

〈표 4-1〉 외국사례 조사 분석항목

\begin{tabular}{l|l}
\hline \multicolumn{1}{c|}{ 국가별 공항 현황 } & \multicolumn{1}{|c}{ 국가별 지방공항 활용 외래객 유치 전략 } \\
\hline - 전국에서 운영 중인 공항 개수 & - 지방공항 국제노선 확충 \\
- 국제공항 보유 현황 & - 지방공항 관광수용태세 확립 \\
• 공항의 지역별 분포 & - 지방공항 연계교통 서비스 개선 \\
- 주요 공항의 국제선 운항 현황 & - 지방공항 외래관광객 유치 마케팅 \\
\hline
\end{tabular}




\section{제2절 일본 사례 조사}

\section{1. 일본의 공항 개요}

일본의 공항은 공항이 수행하는 기능 및 설치 - 관리 주체에 따라 거점공항과 지 방관리공항으로 크게 구분되며, 전국적으로 총 82 개의 공항을 보유하고 있다. 이 중에 거점공항은 나리타국제공항, 간사이국제공항, 오사카국제공항, 주부국제공항 을 포함하여 모두 28 개로 국제항공운송 및 국내항공운송 네트워크의 거점이 되는 공항으로 분류되어 중요한 역할을 수행하고 있다. 지방관리공항은 시즈오카공항, 아오모리공항, 사가공항, 고베공항 등을 포함하여 모두 54 개로 국제항공운송 및 국 내항공운송 네트워크를 형성하는 역할을 담당하고 있다.

\section{가. 공항 유형별 현황}

- 거점공항: 28 개 공항

- 회사관리공항: 나리타국제공항, 주부국제공항, 간사이국제공항, 오사국제공 항 등 4 개

- 국가관리공항: 도쿄국제공항, 신치토세공항, 왓카나이공항, 구시로공항, 하 코다테공항, 센다이공항, 니가타공항, 히로시마공항, 다카마쓰공항, 마쓰야 마공항, 고치공항, 후쿠오카공항, 기타규슈공항, 나가사키공항, 구마모토공 항, 오이타공항, 미야자키공항, 가고시마공항, 나하공항 등 19 개

- 특정지방관리공항5): 아사히카와공항, 오비히로공항, 아키타공항, 야마가타 공항, 야마구치우베 공항 등 5개

5) 특정지방관리공항이란 국가가 설치하고 지방공공단체가 관리하는 공항을 뜻함 
- 지방관리공항: 54 개 공항

- 홋카이도지방: 리시리공항 외 5 개

- 도호쿠지방: 아오모리공항 외 4 개

- 간사이지방: 오시마공항 외 4 개

- 주부지방: 시즈오카공항 외 5개

- 긴키지방: 고베공항 외 1 개

- 주고쿠지방(혼슈서부지방): 돗토리공항 외 4개

- 규슈지방(오키나와현 제외): 사가공항 외 12 개

- 규슈지방(오키나와현 포함): 아구니공항 외 11개

\section{나. 간사이공항의 국제선 운항 현황}

2019 년 간사이공항의 국제선은 아시아 11 개국 49도시, 오세아니아 2 개국 3 도 시, 유럽 5 개국 6 도시, 중동 1 개국 1 도시, 북미 1 개국 5 도시로 총 20 개국 64 도시에 직항노선을 운행하고 있으며 주당 총 1284.5 편을 운행하고 있다. 특히 아시아 노선 이 전체 국제노선의 약 $90.7 \%$ 를 차지하고 있으며, 그 중에서도 중국이 $30.8 \%$, 한 국이 $27.8 \%$ 의 점유율을 보이고 있다.

\section{1) 일본국적 항공사의 운항 점유율}

간사이공항의 전체 운항 현황에서 일본국적 항공사의 점유율은 약 $12.5 \%$ 에 불과 하며, 외국국적 항공사가 나머지 $87.5 \%$ 를 차지하고 있다.

〈표 4-2〉 간사이공항 일본국적 항공사의 운항 점유율

\begin{tabular}{c|c|c|c|c|c|c}
\hline \multirow{2}{*}{ 구분 } & \multicolumn{2}{|c|}{ 일본국적 항공사 } & \multicolumn{2}{|c|}{ 외국국적 항공사 } & \multirow{2}{*}{ 합계 } & \multirow{2}{*}{ 점유율(\%) } \\
\cline { 2 - 5 } & 소계 & 점유율(\%) & 소계 & 점유율(\%) & & \\
\hline 취항국가 & 7 & 35.0 & 13 & 65.0 & 20 & 100 \\
\hline 취항도시 & 14 & 21.9 & 50 & 78.1 & 64 & 100 \\
\hline 운항편수 & 160.5 & 12.5 & 1125 & 87.5 & 1285.5 & 100 \\
\hline
\end{tabular}

자료: 일본 국토교통성 항공국 홈페이지 세부내용 재정리 


\section{2) 국적별 항공사 및 구분}

국적별 항공사의 취항 현황을 살펴보면, 전체 운항횟수의 $30.8 \%$ 를 차지하고 있 는 중국국적의 항공사가 13 개사로 가장 많으며, 그 다음으로 한국이 8 개사, 일본이 5 개사로 확인된다. 동남아시아 중에서는 태국이 4 개사로 일본 간사이공항에서 가장 활발히 운항하고 있음을 알 수 있다. 또한 FSC(Full Service Carrier)와 LCC(Low Cost Carrier)로 구분하여 살펴보면, 전체 항공회사 59개사 중에 FSC가 35개사, LCC가 24개사로 나타났다.

〈표 4-3〉 간사이공항의 국적별 항공사 구분

\begin{tabular}{c|c|c|c}
\hline 구분 & 항공사 수 & FSC & LCC \\
\hline 일본 & 5 & 2 & 3 \\
\hline 한국 & 8 & 2 & 6 \\
\hline 중국 & 13 & 9 & 4 \\
\hline 싱가포르 & 2 & 1 & 1 \\
\hline 인도네시아 & 1 & 1 & 0 \\
\hline 말레이시아 & 2 & 1 & 1 \\
\hline 태국 & 4 & 1 & 3 \\
\hline 필리핀 & 2 & 1 & 1 \\
\hline 베트남 & 3 & 1 & 1 \\
\hline 마카오 & 1 & 1 & 1 \\
\hline 홍콩 & 3 & 2 & 0 \\
\hline 대만 & 3 & 2 & 0 \\
\hline 호주 & 2 & 1 & 0 \\
\hline 뉴질랜드 & 1 & 1 & 0 \\
\hline 영국 & 1 & 1 & 0 \\
\hline 네덜란드 & 1 & 1 & 0 \\
\hline 독일 & 1 & 1 & 0 \\
\hline 프랑스 & 1 & 1 & 1 \\
\hline 핀란드 & 1 & 35 & 1 \\
\hline 미국 & 39 & & 1 \\
\hline UAE & 1 & 1 & 1 \\
\hline 합계 & 1 & 1 & 0 \\
\hline
\end{tabular}

자료: 일본 국토교통성 항공국 홈페이지 세부내용 재정리 


\section{3) 한국노선 운항 현황}

한국노선은 서울, 부산, 제주, 청주, 대구, 무안 6 개 도시에 운항하고 있으며, 피 치 에비에이션(전일본공수(ANA)계열의 LCC) 이외에는 한국국적 항공사가 취항하 고 있다. 대한항공과 아시아나항공을 제외한 LCC의 운항 비율은 전체의 약 $73.5 \%$ 를 차지하고 있다.

〈표 4-4〉 간사이공항의 한국노선 운항 현황

\begin{tabular}{|c|c|c|c|c|}
\hline 도시명 & 항공사 코드 & 항공사명 & 운항/주(편수) & LCC \\
\hline \multirow{8}{*}{ 서울 } & $7 C$ & 제주항공 & 42 & 42 \\
\hline & KE & 대한항공 & 35 & - \\
\hline & LJ & 진에어 & 28 & 28 \\
\hline & MM & 피치 에비에이션 & 28 & 28 \\
\hline & $\mathrm{OZ}$ & 아시아나항공 & 42 & - \\
\hline & RS & 에어서울 & 13 & 13 \\
\hline & TW & 티웨이항공 & 18 & 18 \\
\hline & ZE & 이스타항공 & 14 & 14 \\
\hline \multirow{7}{*}{ 부산 } & $7 C$ & 제주항공 & 14 & 14 \\
\hline & BX & 에어부산 & 21 & 21 \\
\hline & $\mathrm{KE}$ & 대한항공 & 14 & - \\
\hline & LJ & 진에어 & 14 & 14 \\
\hline & MM & 피치 에비에이션 & 7 & 7 \\
\hline & TW & 티웨이항공 & 7 & 7 \\
\hline & ZE & 이스타항공 & 4 & 4 \\
\hline \multirow{2}{*}{ 제주 } & $\mathrm{KE}$ & 대한항공 & 4 & - \\
\hline & TW & 티웨이항공 & 7 & 7 \\
\hline \multirow{2}{*}{ 청주 } & $7 C$ & 제주항공 & 7 & 7 \\
\hline & ZE & 이스타항공 & 4 & 4 \\
\hline \multirow{2}{*}{ 대구 } & $\mathrm{BX}$ & 에어부산 & 14 & 14 \\
\hline & TW & 티웨이항공 & 14 & 14 \\
\hline 무안 & $7 C$ & 제주항공 & 7 & 7 \\
\hline \multicolumn{3}{|c|}{ 합계 } & 358 & 263 \\
\hline
\end{tabular}

자료: 일본 국토교통성 항공국 홈페이지 세부내용 재정리 


\section{4) 중국노선 운항 현황}

중국노선은 베이징, 상하이, 항저우 등의 대도시뿐만 아니라 지방 소도시에 이르 기까지 중국전역의 28 개 도시에 운항하고 있다. 일본국적항공사는 베이징노선의 일 본항공을 제외한 다른 노선은 ANA계열(ANA와 피치 에비에이션)이 운행하고 있다. 즉, ANA가 중국노선에 집중하고 있다는 것을 알 수 있다. 피치 에비에이션을 포함 한 LCC 운항비율은 전체의 $17.4 \%$ 를 차지하며, 한국노선과 비교하면 LCC 점유율 에 많은 차이를 보이고 있다.

〈표 4-5〉간사이공항의 중국노선 운항 현황

\begin{tabular}{|c|c|c|c|c|}
\hline 도시명 & 항공사 코드 & 항공사명 & 운항/주(편수) & LCC \\
\hline 하얼빈 & $\mathrm{CZ}$ & 중국남방항공 & 3 & - \\
\hline 옌지 & MU & 중국동방항공 & 2 & - \\
\hline 하이코우 & $\mathrm{HU}$ & 하이난항공 & 3 & - \\
\hline 구이양 & $\mathrm{CZ}$ & 중국남방항공 & 2 & - \\
\hline \multirow{2}{*}{ 광저우 } & $9 \mathrm{C}$ & 춘추항공 & 7 & 7 \\
\hline & $\mathrm{CZ}$ & 중국남방항공 & 14 & - \\
\hline \multirow{5}{*}{ 항저우 } & $\mathrm{CA}$ & 중국국제항공 & 4 & - \\
\hline & $\mathrm{JD}$ & 베이징캐피탈항공 & 2 & - \\
\hline & MF & 샤먼항공 & 7 & 7 \\
\hline & MU & 중국동방항공 & 2 & - \\
\hline & $\mathrm{NH}$ & 전일본공수(ANA) & 7 & - \\
\hline 지난 & SC & 산둥항공 & 7 & - \\
\hline 충칭 & $9 \mathrm{C}$ & 춘추항공 & 3 & 3 \\
\hline \multirow{8}{*}{ 상하이 } & $9 \mathrm{C}$ & 춘추항공 & 14 & 14 \\
\hline & CA & 중국국제항공 & 21 & - \\
\hline & $\mathrm{CZ}$ & 중국남방항공 & 7 & - \\
\hline & $\mathrm{HO}$ & 준야오항공 & 17.5 & - \\
\hline & $\mathrm{JL}$ & 일본항공 & 14 & - \\
\hline & MM & 피치 에비에이션 & 7 & 7 \\
\hline & $\mathrm{MU}$ & 중국동방항공 & 21 & - \\
\hline & $\mathrm{NH}$ & 전일본공수 & 14 & - \\
\hline \multirow{3}{*}{ 선전 } & $\mathrm{CZ}$ & 중국남방항공 & 6 & - \\
\hline & $\mathrm{HU}$ & 하이난항공 & 3 & - \\
\hline & $\mathrm{ZH}$ & 선전항공 & 7 & - \\
\hline
\end{tabular}




\begin{tabular}{|c|c|c|c|c|}
\hline 도시명 & 항공사 코드 & 항공사명 & 운항/주(편수) & LCC \\
\hline \multirow{2}{*}{ 청두 } & $3 U$ & 쓰촨항공 & 7 & - \\
\hline & CA & 중국국제항공 & 7 & - \\
\hline \multirow{2}{*}{ 시안 } & $3 U$ & 쓰촨항공 & 7 & - \\
\hline & $9 \mathrm{C}$ & 춘추항공 & 1 & 1 \\
\hline \multirow{3}{*}{ 칭다오 } & $\mathrm{HO}$ & 준야오항공 & 7 & - \\
\hline & $\mathrm{NH}$ & 전일본공수(ANA) & 7 & - \\
\hline & $\mathrm{SC}$ & 산둥항공 & 7 & - \\
\hline \multirow{4}{*}{ 다롄 } & $9 \mathrm{C}$ & 춘추항공 & 6.5 & 6.5 \\
\hline & $\mathrm{CZ}$ & 중국남방항공 & 7 & - \\
\hline & $\mathrm{MU}$ & 중국동방항공 & 7 & - \\
\hline & $\mathrm{NH}$ & 전일본공수(ANA) & 7 & - \\
\hline 창사 & $\mathrm{CZ}$ & 중국남방항공 & 2 & - \\
\hline 창즈 & $\mathrm{CZ}$ & 중국남방항공 & 2 & - \\
\hline \multirow{4}{*}{ 톈진 } & $9 \mathrm{C}$ & 춘추항공 & 4.5 & 4.5 \\
\hline & BK & 오케이항공 & 4 & 4 \\
\hline & CA & 중국국제항공 & 4 & - \\
\hline & GS & 톈진항공 & 14 & - \\
\hline \multirow{2}{*}{ 난징 } & $\mathrm{HO}$ & 준야오항공 & 14 & - \\
\hline & $\mathrm{MU}$ & 중국동방항공 & 5 & - \\
\hline 난통 & $\mathrm{ZH}$ & 선전항공 & 4 & - \\
\hline 닝보 & $\mathrm{MU}$ & 중국동방항공 & 2 & - \\
\hline \multirow{2}{*}{ 우한 } & $9 \mathrm{C}$ & 춘추항공 & 2 & 2 \\
\hline & $\mathrm{CZ}$ & 중국남방항공 & 2 & - \\
\hline 푸저우 & MF & 샤먼항공 & 6 & 6 \\
\hline \multirow{4}{*}{ 베이징 } & CA & 중국국제항공 & 14 & - \\
\hline & $\mathrm{MU}$ & 중국동방항공 & 7 & - \\
\hline & $\mathrm{NH}$ & 전일본공수(ANA) & 7 & - \\
\hline & $\mathrm{ZH}$ & 선전항공 & 7 & - \\
\hline 우시 & $\mathrm{ZH}$ & 선전항공 & 14 & - \\
\hline 양저우 & $9 \mathrm{C}$ & 춘추항공 & 3 & 3 \\
\hline 샤먼 & MF & 샤먼항공 & 4 & 4 \\
\hline 선양 & $\mathrm{CZ}$ & 중국남방항공 & 6 & - \\
\hline 상하이 & $\mathrm{HO}$ & 준야오항공 & 3.5 & - \\
\hline \multicolumn{3}{|c|}{ 합계 } & 396 & 69 \\
\hline
\end{tabular}

자료: 일본 국토교통성 항공국 홈페이지 세부내용 재정리 


\section{5) 그 외 아시아노선 운항 현황}

기타 아시아노선으로는 홍콩이 111회, 대만이 104회로 많으며, 동남아시아노선 으로는 태국이 46회, 베트남이 42회로 운항하고 있다. 피치 에비에이션과 제트스타 재팬을 포함한 LCC 운항 비율은 약 $38.2 \%$ 로 나타났다.

〈표 4-6〉 간사이공항의 기타 아시아노선 운항 현황

\begin{tabular}{|c|c|c|c|c|c|}
\hline 국가명 & 도시명 & 항공사 코드 & 항공사명 & $\begin{array}{l}\text { 운항/주 } \\
\text { (편수) }\end{array}$ & $\mathrm{LCC}$ \\
\hline \multirow{2}{*}{ 인도네시아 } & 자카르타 & GA & 가루다인도네시아 & 3 & - \\
\hline & 덴파사르 & $\mathrm{GA}$ & 가루다인도네시아 & 7 & - \\
\hline \multirow{2}{*}{ 싱가포르 } & \multirow{2}{*}{ 싱가포르 } & SQ & 싱가포르항공 & 14 & - \\
\hline & & TR & 스쿠트항공 & 4 & 4 \\
\hline \multirow{5}{*}{ 태국 } & \multirow{5}{*}{ 방콕 } & $\mathrm{JL}$ & 일본항공 & 7 & - \\
\hline & & TG & 타이 국제항공 & 14 & - \\
\hline & & $S L$ & 타이라이언에어 & 5 & 5 \\
\hline & & XJ & 타이 에어아시아 X & 14 & 14 \\
\hline & & $X W$ & 녹스쿠트항공 & 6 & 6 \\
\hline \multirow{4}{*}{ 필리핀 } & 세부 & $P R$ & 필리핀항공 & 7 & - \\
\hline & \multirow{3}{*}{ 마닐라 } & $5 \mathrm{~J}$ & 세부퍼시픽항공 & 7 & 7 \\
\hline & & GK & 젯스타 재팬 & 2.5 & 2.5 \\
\hline & & PR & 필리핀항공 & 11 & - \\
\hline \multirow{6}{*}{ 베트남 } & 다낭 & $\mathrm{VN}$ & 베트남항공 & 7 & - \\
\hline & \multirow{3}{*}{ 하노이 } & $\mathrm{BL}$ & 젯스타퍼시픽항공 & 7 & 7 \\
\hline & & VJ & 비엣젯항공 & 7 & 7 \\
\hline & & VN & 베트남항공 & 7 & - \\
\hline & \multirow{2}{*}{ 호치민 } & VJ & 비엣젯항공 & 7 & 7 \\
\hline & & VN & 베트남항공 & 7 & - \\
\hline 마카오 & 마카오 & NX & 마카오항공 & 7 & - \\
\hline \multirow{2}{*}{ 말레이시아 } & \multirow{2}{*}{ 쿠알라룸푸르 } & D7 & 에어아시아 X & 7 & 7 \\
\hline & & $\mathrm{MH}$ & 말레이시아항공 & 10 & - \\
\hline \multirow{6}{*}{ 홍콩 } & \multirow{6}{*}{ 홍콩 } & $C X$ & 캐세이퍼시픽항공 & 35 & - \\
\hline & & GK & 젯스타 재팬 & 4 & 4 \\
\hline & & $H X$ & 홍콩항공 & 21 & - \\
\hline & & MM & 피치 에비에이션 & 11 & 11 \\
\hline & & $\mathrm{NH}$ & 전일본공수 & 7 & - \\
\hline & & UO & 홍콩 익스프레스항공 & 33 & 33 \\
\hline
\end{tabular}




\begin{tabular}{|c|c|c|c|c|c|}
\hline 국가명 & 도시명 & 항공사 코드 & 항공사명 & $\begin{array}{l}\text { 운항/주 } \\
\text { (편수) }\end{array}$ & LCC \\
\hline \multirow{13}{*}{ 대만 } & \multirow{4}{*}{ 가오슝 } & BR & 에바항공 & 7 & - \\
\hline & & $\mathrm{Cl}$ & 중화항공 & 11 & - \\
\hline & & IT & 타이거에어 타이완 & 3 & 3 \\
\hline & & MM & 피치 에비에이션 & 7 & 7 \\
\hline & 타이난 & $\mathrm{Cl}$ & 중화항공 & 2 & - \\
\hline & \multirow{8}{*}{ 타이베이 } & $\mathrm{BR}$ & 에바항공 & 28 & - \\
\hline & & $\mathrm{Cl}$ & 중화항공 & 28 & - \\
\hline & & IT & 타이거에어 타이완 & 20 & 20 \\
\hline & & $\mathrm{JL}$ & 일본항공 & 7 & - \\
\hline & & JW & 바닐라에어 & 7 & 7 \\
\hline & & MM & 피치 에비에이션 & 14 & 14 \\
\hline & & $\mathrm{NH}$ & 전일본공수(ANA) & 7 & - \\
\hline & & $\mathrm{ZH}$ & 선전항공 & 7 & - \\
\hline UAE & 두바이 & EK & 에미레이트항공 & 7 & - \\
\hline \multicolumn{4}{|c|}{ 합계 } & 433.5 & 165.5 \\
\hline
\end{tabular}

자료: 일본 국토교통성 항공국 홈페이지 세부내용 재정리

\section{6) 구미주·오세아니아노선 운항 현황}

장거리노선의 경우 유럽과 북미노선은 FSC가 취항하고 있으며, 중거리노선은 오 세아니아노선에서 FSC와 LCC 모두 운항하고 있다. 괌노선은 한국의 LCC가 운항 하고 있으며, 하와이노선에도 2개의 LCC가 운항하고 있다. LCC 운항 비율은 전체 의 약 $22.3 \%$ 를 차지하고 있다.

〈표 4-7〉 간사이공항의 구미주·오세아니아노선 운항 현황

\begin{tabular}{c|c|c|c|c|c}
\hline \multirow{2}{*}{ 국가명 } & 도시명 & 항공사 코드 & 항공사명 & $\begin{array}{c}\text { 운함/주 } \\
\text { (편수) }\end{array}$ & LCC \\
\hline \multirow{2}{*}{ 호주 } & 케언즈 & $\mathrm{JQ}$ & 젯스타항공 & 4 & 4 \\
\cline { 2 - 6 } & 시드니 & $\mathrm{QF}$ & 콴타스항공 & 4 & - \\
\hline 뉴질랜드 & 오클랜드 & $\mathrm{NZ}$ & 에어뉴질랜드 & 1 & - \\
\hline 영국 & 런던 & $\mathrm{BA}$ & 영국항공 & 4 & - \\
\hline \multirow{2}{*}{ 네덜란드 } & 암스테르담 & $\mathrm{KL}$ & $\mathrm{KLM}$ & 7 & - \\
\hline \multirow{2}{*}{ 독일 } & 프랑크푸르트 & $\mathrm{LH}$ & 루프트한자 & 1 & - \\
\cline { 2 - 6 } & 뮌헨 & $\mathrm{LH}$ & 루프트한자 & 6 & - \\
\hline
\end{tabular}




\begin{tabular}{|c|c|c|c|c|c|}
\hline 국가명 & 도시명 & 항공사 코드 & 항공사명 & $\begin{array}{l}\text { 운항/주 } \\
\text { (편수) }\end{array}$ & LCC \\
\hline 핀란드 & 헬싱키 & AY & 핀에어 & 10 & - \\
\hline 프랑스 & 파리 & $\mathrm{AF}$ & 에어프랑스 & 7 & - \\
\hline \multirow{11}{*}{ 미국 } & \multirow{3}{*}{ 괌 } & $7 C$ & 제주항공 & 6 & 6 \\
\hline & & TW & 티웨이항공 & 7 & 7 \\
\hline & & UA & 유나이티드항공 & 7 & - \\
\hline & 샌프란시스코 & UA & 유나이티드항공 & 7 & - \\
\hline & 시애틀 & $\overline{D L}$ & 델타항공 & 5 & - \\
\hline & \multirow{5}{*}{ 호놀룰루 } & D7 & 에어아시아 X & 4 & 4 \\
\hline & & $\mathrm{DL}$ & 델타항공 & 7 & - \\
\hline & & HA & 하와이안항공 & 7 & - \\
\hline & & $J \mathrm{~L}$ & 일본항공 & 7 & - \\
\hline & & TR & 스쿠트항공 & 4 & 4 \\
\hline & 로스앤젤레스 & $\mathrm{JL}$ & 일본항공 & 7 & - \\
\hline \multicolumn{4}{|c|}{ 합계 } & 112 & 25 \\
\hline
\end{tabular}

\section{2. 일본의 지방공항 활용 외래객 유치 전략}

\section{가. 공항 세일즈 지원 정책}

'일본의 미래를 지원하는 관광비전(明日の日本を支える観光ビジョン)'의 목표를 달성하기 위해 지방공항으로의 LCC 등 국제선의 신규취항 및 증편을 추진할 필요 성이 높아짐에 따라, 2017년 7월 나리타공항, 하네다공항, 간사이공항을 제외한 전 국의 공항 중에서 지자체 등이 방일여행객 유치 및 국제선 취항 촉진을 추진하는 27 개의 공항을 '방일여행객 유치 지원공항'으로 인정하는 제도를 시행했다. 해당 공 항에 대하여 일본정부는 신규취항 및 증편을 지원하거나 공항의 수용태세환경 정비 를 지원하고 있다.

특히, 지방공항의 국제노선 신규취항 및 증편을 지원하기 위한 공항 세일즈 방안 으로 관계부처와 연계하여 다음과 같은 시책을 추진하고 있다.

\section{1) 공항 세일즈 상담창구 운영}

지원 공항에 설치된 협의회 등으로부터 일본정부관광국(JNTO)이 상담을 받아, 
$\mathrm{JNTO}$ 해외사무소를 통해 정보를 제공하고 있다. 현재 동아시아의 서울, 북경, 상 해, 홍콩, 동남아시아의 방콕, 싱가포르, 자카르타, 구미주·호주의 시드니, 뉴욕, 로 스앤젤레스, 토론토, 파리, 런던, 프랑크푸르트, 모스크바 등 15 개의 JNTO 사무소 에서 대응하고 있다.

\section{2) 전문상담회 등의 참가 지원}

각국의 주요 항공사, 공항 등이 모이는 전문상담회인 'World Routes'나 'Routes Asia' 등에 JNTO가 참가할 경우, 지원 공항의 협의회 등이 참가할 수 있도록 적극 적으로 지원하고 있다.

\section{3) 해외에서 적극적인 PR 지원}

지원 공항으로의 신규취항 및 증편이 정해지면, 항공사 및 여행사와 연계하여 공 동광고를 시행하는 등 해외에 있어서의 PR활동을 지원하고 있다. 예를 들어, 2016 년에는 이베리아항공의 마드리드-나리타 노선 신규취항에 맞춰서 이베리아항공과 공동광고를 실시했다.

\section{나. 사가공항(佐賀空港) 사례}

1) 지역 취항 촉진 및 여객 편의성 향상을 위한 시책

일본의 사가공항은 외국인 관광객의 이용 편의성을 향상시키기 위해, 국제선의 운항에 맞춰서 체크인 카운터 등에 통역사를 배치하고, 현내의 관광 및 숙박 등 정 보를 제공하는 관광어플리케이션(6개 언어별 대응), 관광안내 통역서비스를 365일, 24 시간 언제든 무료로 이용할 수 있는 콜센터(15개 언어별 대응)를 설치하였다. 또 한, 국제선 정기편의 이용객 설문조사를 통해 이용객 니즈를 파악하고, 항공사 및 공항시설 등 관계자에게 정보를 제공함으로써 여행 만족도를 향상시켰다. 한편, 지 방공항 연계교통수단의 이용 편의성을 향상시키기 위해 공항과 각 지역을 연결하는 리무진 택시를 도입하고, 최초 24 시간을 1,000 엔에 이용할 수 있는 렌터카 캠페인 을 실시한 바 있다. 
2) 주요 신규취항 및 증편 현황(2018년 기준)

- 타이베이노선: 타이거에어 타이완(2편/주, 10월부터 신규취항)

- 부산노선: 티웨이항공(4편/주, 12월부터 신규취항)

- 대구노선: 티웨이항공(2편/주, 12월부터 프로그램차터 항공편 운항)

- 상하이노선: 춘추항공(3편 $\rightarrow 4$ 편/주, 2019년 1월부터 증편)

[그림 4-1] 사가공항 입국 외국인 수 추이

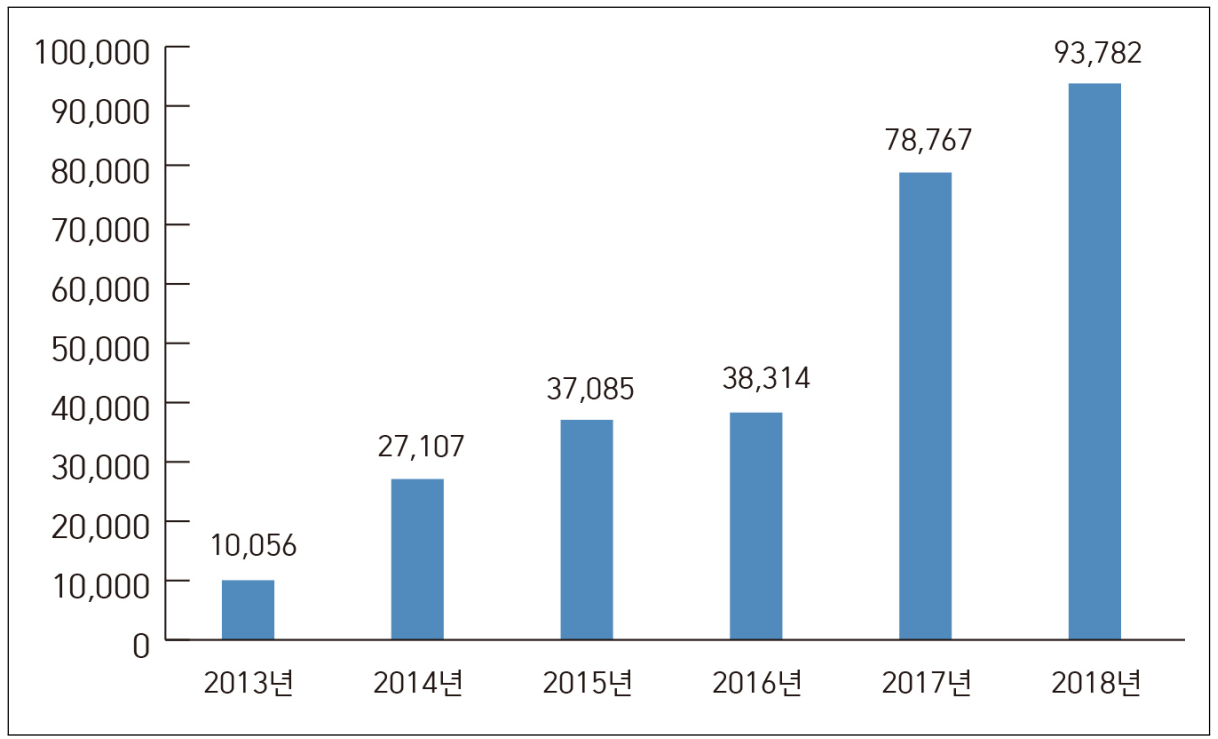

자료: 일본 법무성 출입국관리통계, 연구자 재정리

\section{3) 정부의 지원 현황}

- 타이베이노선 및 상해노선 등의 경비보조(지원공항 인정사업)

- 수용환경 고도화 지원: 교통접근시설(렌터카 전용시설) 정비 지원

- 해외 PR지원: JNTO와 연계하여, 타이거에어 타이완과 온라인 광고에 의한 판매 촉진 및 티웨이항공과 공동으로 동영상 광고 전개 


\section{나. 요나고공항(米子空港) 사례}

1) 지역 취항 촉진 및 여객 편의성 향상을 위한 시책

동일 항공회사가 취항하는 오카야마현과 연락회의를 구축하여, 주로 해당 항공회 사의 여객을 대상으로 해외 미디어 및 블로거를 공동으로 초빙하여 현지잡지에 게 재되도록 하였다. 또한, 두 공항의 이용촉진을 위해 렌터카를 활용한 주유형 관광플 랜을 제안하고, 동시에 렌터카용 지도를 제작하여 광역 관광수요 창출을 위해 노력 하고 있다. 공항을 이용하는 여객의 렌터카 이용촉진에 있어서 현내에 있는 도톳리 공항과 두 공항 간의 편도이용도 포함시켜 상호 공항에서의 이용을 촉진하고 있다. 또한, 수요창출의 일환으로서 럭비월드컵 및 도쿄올림픽 등의 국제대회와 연계하여 SNS 등을 활용해 국제선 정기편 및 국내선 이용 등에 관한 정보를 방일 외국인 관 광객들에게 적극적으로 제공하고 있다.

2) 주요 신규취항 및 증편 현황(2018년)

- 서울노선: 에어서울(5편 $\rightarrow 6$ 편/주, 10 월부터 증편)

- 홍콩노선: 홍콩항공(2편 $\rightarrow 3$ 편/주, 12 월부터 증편)

[그림 4-2] 요나고공항 입국 외국인 수 추이

(단위: 명)

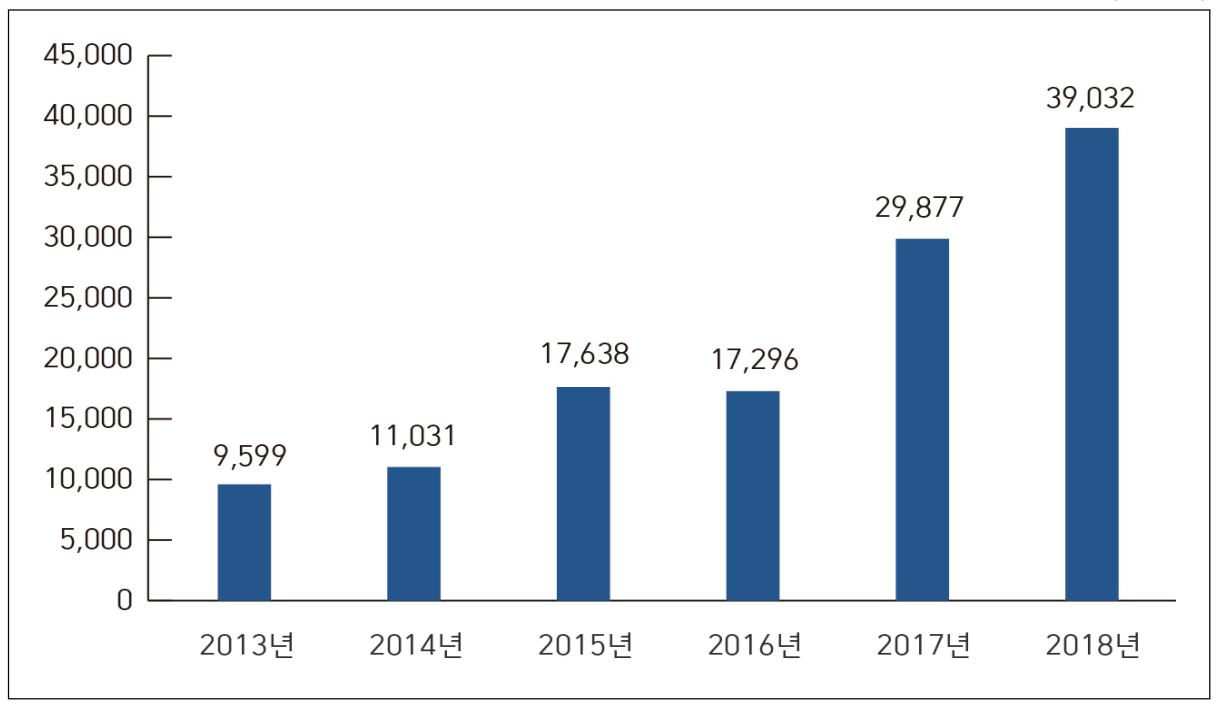

자료: 일본 법무성 출입국관리통계, 연구자 재정리 
3) 정부의 지원 현황

- 서울노선 및 홍콩노선 등 착륙료 할인 및 경비보조(지원공항 인정사업)

- 수용환경 고도화 지원: 탑승브릿지 증설, 대합실 확장, 수화물 컨베이어 정비 등

- 해외 PR지원: JNTO와 연계하여, 에어서울과 공동으로 현지 상업시설에서 광고활 동 전개 


\section{제3절 태국 사례 조사}

\section{1. 태국의 공항 개요}

태국은 전국적으로 총 39개의 공항이 운영되고 있으며, 이를 관할하는 공항운영사 업자는 태국공항공사(AOT), 공항국(DOA), 태국왕국해군(RTN), 방콕항공(BAC) 등 4 개의 국가 및 민간사업자가 있다. 태국으로 입국하는 외래객의 $99 \%$ 이상이 태국공항 공사(AOT)에서 운영하는 6개의 국제공항(International Airport)을 이용하고 있다.

\section{가. 국제공항(International Airport) 현황}

- 태국공항공사(Airports of Thailand Public Company Limited, AOT) 관 할: 6개 공항

- 도심거점형 공항: 2 개 공항

。 수완나폼 공항(Suvarnabhumi Airport(BKK))

。돈무앙 공항(Don Mueang International Airport(DMK))

- 지역연계형 공항: 4 개 공항

치앙마이 공항(Chiang Mai International Airport(CNX))

。푸켓 공항(Phuket International Airport(HKT))

- 핫야이 공항(Hat Yai International Airport(HDY))

。치앙라이 공항(Chiang Rai International Airport(CEI))

- 공항국(Department of Airports, DOA) 관할: 29개 공항

- 29개의 지방공항(regional airports)

- 태국왕국해군(Royal Thai Navy, RTN) 관할: 1 개 공항

- 우타파오 공항(U-Tapao Pattaya International Airport(UTP)) 
- 방콕항공(Bangkok Airways Company, $\mathrm{BAC}$ ) 관할: 3 개 공항

- 수코타이 공항(Sukhothai Airport(THS))

사무이 공항(Sukhothai Airport(USM))

- 트래드 공항(Trad Airport)

[그림 4-3] 태국의 국제공항 현황

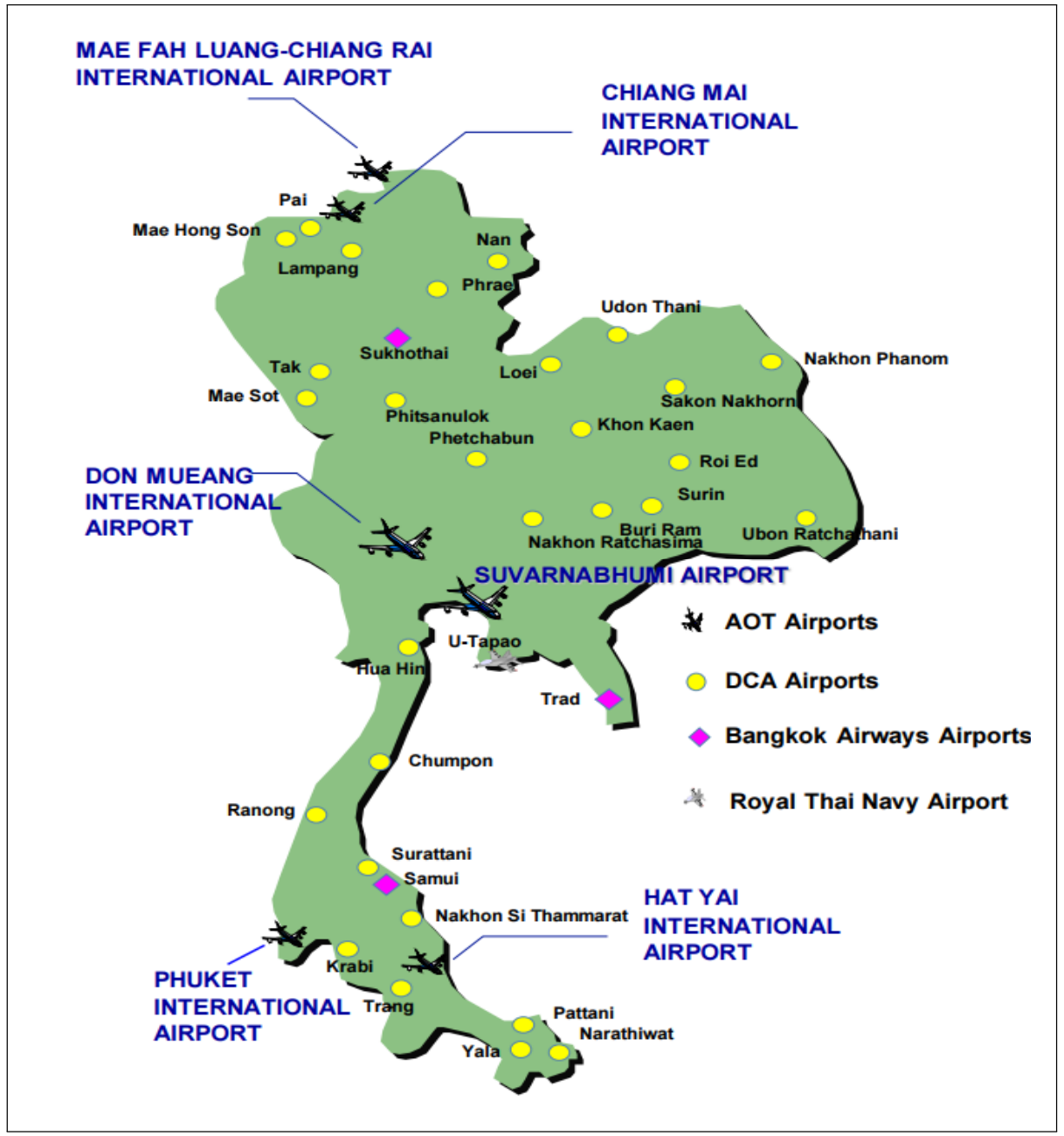

자료: Airports of Thailand Plc., 2019 


\section{나. 주요 공항의 국제선 운항 현황}

1) 연간 국제선 운항편수

(1) 공항별 대형항공사(FSC)의 운항편수 현황

- 방콕 도심거점형 공항인 수완나폼 공항(BKK)과 돈무앙 공항(DMK)의 FSC 운항편수 비율은 약 $82 \%$ 로, 그 외 4 개 지역연계형 공항 대비 절대 우위를 점 하고 있음

- 수완나폼 공항(79\%), 돈무앙 공항(3\%), 그 외 4개 공항(18\%)

- 2개의 도심거점형 공항 중 수완나폼 공항(BKK) FSC의 운항편수 비율이 $79 \%$ 로 돈무앙 공항(DMK) 대비 절대적으로 높음

(2) 공항별 저가항공사(LCC)의 운항편수 현황

- 도심거점형 공항 중 돈무앙 공항(DMK)이 LCC 운항편수 비율이 $53 \%$ 로 수완 나폼 공항(BKK) 및 지역연계형 공항 대비 절대 우위를 점유함

- 수완나폼 공항(24\%), 돈무앙 공항(53\%), 그 외 공항(23\%)

- 도심거점형 공항인 수완나폼 공항과 그 외 지역연계형 공항 대비 LCC 점유 비가 높은 것은 돈무앙 공항이 도심거점형 공항이면서 중단거리 국제노선 을 집중적으로 운영하고 있기 때문임

(3) 공항별 $\mathrm{FSC} / \mathrm{LCC}$ 운항편수의 상관성

- 수완나폼 공항(BKK)은 우리나라 인천국제공항과 같이 국제선 중심의 $\mathrm{FSC}$ 가 주로 이용되고, 돈무앙 공항( $\mathrm{DMK}$ )은 김포공항과 같이 $\mathrm{LCC}$ 중심의 국제선이 주로 운영되고 있음

- 2006년 9월 신국제공항인 수완나폼 공항이 개항되면서, 돈무앙 공항은 국 내선 전용공항으로 전환되었으나, 수완나폼 공항의 집중시간대 Slot 혼잡문 제가 대두되면서, 2012년 이후 부터는 일부 LCC 중심의 국제선이 운영되 기 시작하였음

- 2013 2019년까지 7년간 공항별 평균 LCC 운항비율은 도심거점형 공항 보 다 지역연계형 공항의 점유비가 대체적으로 높게 나타남

- 도심거점형 공항: 수완나폼 공항(12\%), 돈무앙 공항(88\%) 
- 지역연계형 공항: 치앙마이 공항(43\%), 핫야이 공항(94\%), 푸켓 공항(37\%), 치앙라이 공항(4\%)

- 현재까지도 $\mathrm{AOT}$ 관할 공항 중 유일하게 치앙라이(CEI) 공항은 항공기 운항과 항공여객운송에 있어 안정적이지 못한 상황임

〈표 4-8〉 태국 주요 공항의 항공기 운항 현황

(단위: 1,000 편, \%)

\begin{tabular}{|c|c|c|c|c|c|c|c|c|c|c|c|c|}
\hline \multirow{2}{*}{ 공항 } & \multicolumn{3}{|c|}{2013} & \multicolumn{3}{|c|}{2015} & \multicolumn{3}{|c|}{2017} & \multicolumn{3}{|c|}{2019} \\
\hline & FSC & LCC & LCC비율 & FSC & LCC & LCC비율 & FSC & LCC & LCC비율 & FSC & LCC & LCC비율 \\
\hline BKK & 214 & 23 & 10 & 222 & 26 & 10 & 233 & 31 & 12 & 250 & 45 & 15 \\
\hline DMK & 8 & 34 & 81 & 9 & 57 & 87 & 11 & 77 & 87 & 5 & 103 & 95 \\
\hline CNX & 6 & 3 & 33 & 9 & 7 & 42 & 11 & 8 & 40 & 12 & 13 & 52 \\
\hline HDY & 0.1 & 2 & 93 & 0.1 & 2 & 92 & 0.2 & 2 & 91 & 0.1 & 2 & 96 \\
\hline HKT & 29 & 11 & 27 & 31 & 13 & 29 & 34 & 20 & 37 & 34 & 31 & 48 \\
\hline CEI & 0.4 & 0 & 0 & 0.5 & 0 & 0 & 0.6 & 0 & 40 & 64 & 1 & 2 \\
\hline
\end{tabular}

\begin{tabular}{c|c|c|c|c|c|c|c}
\hline \multirow{2}{*}{ 공항 } & \multicolumn{3}{|c|}{2013 2019 평균 } & \multicolumn{2}{c|}{ 공항별 운항편 비율 } & \multicolumn{2}{c}{ 도심, 지역공항 점유비 } \\
\cline { 2 - 8 } & FSC & LCC & LCC비율 & FSC비율 & LCC비율 & FSC비율 & LCC비율 \\
\hline BKK & 228 & 30 & 12 & 79 & 24 & 82 & 77 \\
\hline DMK & 9 & 66 & 88 & 3 & 53 & & \\
\hline CNX & 10 & 7 & 43 & 3 & 6 & 3 & 6 \\
\hline HDY & 0.1 & 2 & 94 & 0 & 2 & 0 & 2 \\
\hline HKT & 32 & 19 & 37 & 11 & 15 & 11 & 15 \\
\hline CEI & 10 & 0.4 & 4 & 3 & 0 & 3 & 0 \\
\hline
\end{tabular}

자료: AOT Air Traffic Calendar Year 2013 2019

2) 국제선 FSC/LCC의 여객수송

(1) 공항별 $\mathrm{FSC}$ 의 국제 여객수송 현황

- 수완나폼 공항(BKK)과 돈무앙 공항(DMK)의 FSC 여객수송 점유율이 $87 \%$ 로 항공운항편 점유율 보다 $5 \%$ 가 높게 나타남

- 수완나폼 공항(85\%), 돈무앙 공항(2\%), 그 외 공항(13\%) 
(2) 공항별 $\mathrm{LCC}$ 의 국제 여객수송 현황

- 방콕 도심거점형 공항인 수완나폼 공항(BKK)과 돈무앙 공항(DMK)의 LCC 여객수송 점유율이 $79 \%$ 로 FSC 운항편수 비율이 $87 \%$ 인 것과 같이 지역연계 형 공항 대비 절대 우위를 점유하고 있음

- 수완나폼 공항(24\%), 돈무앙 공항(54\%), 그 외 공항(22\%)

- 2개의 도심거점형 공항 중 LCC의 국제여객 수송 비율은 LCC 중점 운항공 항인 돈무앙 공항 $(\mathrm{DMK})$ 이 절대적으로 높음

(3) 공항별 운영전략과의 상관성

- 수완나폼 공항은 우리나라 인천국제공항과 같이 미주 및 유럽의 중장거리 여 객 수송과 항공사간 동맹체(Alliance) 중심의 운영공항으로 주로 각 대륙을 대표하는 국적기(FSC)가 운항하고 있으며, 돈무앙 공항은 중단거리노선 LCC 중심의 국제공항으로 운영되고 있음

- 세계 모든 도시국가가 그렇듯 태국 또한 기존에 돈무앙 공항 1 개만으로 운 영되다 국제여객수요가 폭주하여 신공항이 건설된 이후, 개항 초기 국내선 만으로 운영되다 신공항이 국제여객을 충족할 수 없어 기존의 일부 중단거 리 국제선인 LCC가 운항하게 됨

- 2013년부터 공항별 LCC의 평균 국제여객 수송비율이 전략적 LCC 운항 공항 (돈무앙 공항)을 제외하고는 도심거점형 공항 보다 지역연계형 공항의 점유율 이 대체적으로 높게 나타남

- 도심거점형 공항: 수완나폼 공항(10\%), 돈무앙 공항(92\%)

- 지역연계형 공항: 치앙마이 공항(50\%), 핫야이 공항(97\%), 푸켓 공항 (34\%), 치앙라이 공항(46\%)

- 도심거점형 공항 보다 지역연계형 공항의 경우, 활주로 및 여행수요를 고려하여 소형기재 중심의 수송으로 인하여 상대적으로 LCC의 의존도가 높게 나타남 
〈표 4-9〉태국 주요 공항의 여객수송 현황

(단위: 100 만명, \%)

\begin{tabular}{|c|c|c|c|c|c|c|c|c|c|c|c|c|}
\hline \multirow{2}{*}{ 공항 } & \multicolumn{3}{|c|}{2013} & \multicolumn{3}{|c|}{2015} & \multicolumn{3}{|c|}{2017} & \multicolumn{3}{|c|}{2019} \\
\hline & FSC & LCC & LCC비율 & FSC & LCC & LCC비율 & FSC & LCC & LCC비율 & FSC & LCC & LCC비율 \\
\hline BKK & 39.0 & 3.5 & 8 & 40.3 & 3.9 & 9 & 44.4 & 5.2 & 10 & 46.1 & 7.3 & 14 \\
\hline DMK & 0.6 & 4.7 & 88 & 1.3 & 7.9 & 86 & 1.2 & 13.2 & 92 & 0.2 & 17.6 & 92 \\
\hline CNX & 0.5 & 0.3 & 39 & 1.0 & 0.9 & 49 & 1.1 & 1.2 & 50 & 1.3 & 1.9 & 51 \\
\hline HDY & 0.0 & 0.2 & 97 & 0.0 & 0.2 & 97 & 0.0 & 0.3 & 95 & 0.0 & 0.3 & 97 \\
\hline HKT & 4.8 & 1.6 & 25 & 5.1 & 1.9 & 27 & 6.0 & 3.2 & 35 & 6.1 & 4.6 & 34 \\
\hline CEI & 0.0 & 0.0 & 0 & 0.0 & 0.0 & 0 & 0.1 & 0.1 & 45 & 0.1 & 0.2 & 46 \\
\hline \multirow{2}{*}{ 공항 } & \multicolumn{5}{|c|}{ 2013 2019 평균 } & \multicolumn{4}{|c|}{ 공항별 여객수송 비율 } & \multicolumn{3}{|c|}{ 도심, 지역공항 수송비 } \\
\hline & \multicolumn{2}{|c|}{ FSC } & LCC & \multicolumn{2}{|c|}{ LCC비율 } & \multicolumn{2}{|c|}{ FSC비율 } & \multicolumn{2}{|l|}{ LCC비율 } & SC비율 & \multicolumn{2}{|c|}{ LCC비율 } \\
\hline BKK & \multicolumn{2}{|c|}{292} & 34 & \multicolumn{2}{|c|}{10} & \multicolumn{2}{|l|}{85} & 24 & & \multirow{2}{*}{87} & \multirow{2}{*}{\multicolumn{2}{|c|}{79}} \\
\hline DMK & \multicolumn{2}{|l|}{6} & 75 & & 92 & \multicolumn{2}{|l|}{2} & \multicolumn{2}{|l|}{54} & & & \\
\hline CNX & \multicolumn{2}{|l|}{7} & 7 & & 50 & \multicolumn{2}{|l|}{2} & \multicolumn{2}{|l|}{5} & 2 & \multicolumn{2}{|r|}{5} \\
\hline HDY & \multicolumn{2}{|c|}{0.1} & 2 & & 97 & \multicolumn{2}{|l|}{0} & \multicolumn{2}{|l|}{1} & 0 & \multicolumn{2}{|r|}{1} \\
\hline HKT & \multicolumn{2}{|l|}{38} & 20 & & 34 & \multicolumn{2}{|l|}{11} & \multicolumn{2}{|l|}{14} & 11 & \multicolumn{2}{|r|}{14} \\
\hline CEI & 0.4 & & 0.4 & & 46 & 0.1 & & 0 & & 0.1 & & 0 \\
\hline
\end{tabular}

자료: AOT Air Traffic Calendar Year 2013 2019

\section{다. 주요 공항의 Slot 및 활주로 보유 현황}

1) Slot 최대용량 및 실제 운영용량

- 공항별/시간대별 허용 항공기 이착륙시간(Slot) 운영 현황은 돈무앙 공항 (48/59-11편 초과)과 치앙마이 공항(20/26-6편 초과)의 경우, 2019년 기준 허용 Slot 보다 초과 운영되고 있어, 이 2개의 공항은 상시 혼잡 공항으로 신 규 노선을 추가하는 데는 한계가 있음

- 상대적으로 수완나폼 공항(68/67), 핫야이 공항(24/24), 푸켓 공항(12/11), 치앙라이 공항(11/10)은 표준 기준 일부 여유가 있음

- 공항별 최대 여객 처리용량은 치앙라이 공항(3.0/2.95백만명)을 제외하고는 모든 공항이 공항 수용용량을 초과하고 있음

- 반면, 공항의 최대 여객 처리용량은 치앙라이 공항을 제외하고는 모든 공항

이 공항 수용용량을 초과하고 있음. 따라서 추가 노선을 개설하기 위해서는 계절별 또는 요일별 안배를 적정히 해야 할 것임 
〈표 4-10〉태국 주요 공항의 Slot 및 여객처리 수용능력 현황

\begin{tabular}{|c|c|c|c|c|c|c|}
\hline \multirow{3}{*}{ 공항 } & \multicolumn{3}{|c|}{ 항공편 (항공편수/시간당) } & \multicolumn{3}{|c|}{ 여객처리용량 (100만명/1년) } \\
\hline & \multirow{2}{*}{$\begin{array}{c}\text { 허용 } \\
\text { 이용횟수 }\end{array}$} & \multicolumn{2}{|c|}{ 실제 이용횟수 } & \multirow{2}{*}{$\begin{array}{l}\text { 최대 여객 } \\
\text { 처리용량 }\end{array}$} & \multicolumn{2}{|c|}{ 실제 처리량 } \\
\hline & & 2018년 & 2019년 & & 2018년 & 2019년 \\
\hline BKK & 68 & 65 & 67 & 45.0 & 62.81 & 64.71 \\
\hline DMK & 48 & 57 & 59 & 30.0 & 40.56 & 41.01 \\
\hline CNX & 20 & 29 & 26 & 12.5 & 18.26 & 17.85 \\
\hline HDY & 24 & 23 & 24 & 8.0 & 10.81 & 11.32 \\
\hline HKT & 12 & 11 & 11 & 2.5 & 4.27 & 4.03 \\
\hline CEI & 11 & 10 & 10 & 3.0 & 2.80 & 2.95 \\
\hline
\end{tabular}

주1) 실제 이용 횟수는 연간 최고 많은 이용횟수 및 실제 처리량을 의미함

2) 각 공항의 허용 이용횟수 및 최대 여객 처리용량은 연간 평균 개념임

자료: Airports of Thailand Plc., 2019

\section{2) 주요 공항의 활주로 보유 현황}

- 도심거점형 공항인 수완나폼 공항(BKK)과 돈무앙 공항(DMK)은 최신 대형기 종까지도 이착륙이 가능한 $3,700 \mathrm{~m}$ 급 활주로와 중소형 항공기가 이착륙할 수 있는 3,500 4,000m급 활주로를 각각 1개씩 총 2개를 보유하고 있는 초대형 급 공항임

- 이외 4개의 지역연계형 공항은 중형항공기 및 소형항공기만 이착륙이 가능 한 3,000 3,400m급 단일 활주로만 보유하고 있어 최신 대형항공기 (B787, A380 등)는 이착륙이 불가능함

- 따라서 수완나폼 공항(BKK)과 돈무앙 공항(DMK) 이외에 지역연계형 공항 은 대형기재 중심의 FSC 유치보다 중소형기재를 운영하는 LCC를 유치하 는 전략이 필요함

- 도심거점형 공항 중 수완나폼 공항(BKK)은 2006년 새로이 신축하여 개항한 공항으로 기존의 돈무앙 공항 $(\mathrm{DMK})$ 보다 총 면적은 5 배, 터미널은 2.5배 정 도의 규모임

- 반면 지역연계형 공항인 치앙마이 공항은 돈무앙 공항의 $1 / 2$ 수준이며, 핫 야이, 푸켓, 치앙라이 공항은 돈무앙 공항과 비슷한 규모이나 활주로는 1 개 만 보유하고 있음 
〈표 4-11〉태국 주요 공항의 면적 및 활주로 현황

\begin{tabular}{c|c|c|c|c}
\hline \multirow{2}{*}{ 공항 } & \multicolumn{2}{|c|}{ 면적 } & \multicolumn{2}{c}{ 활주로 개수 및 길이 } \\
\cline { 2 - 5 } & 총 면적(에이커) & 터미널 면적 $\left(\mathrm{m}^{3}\right)$ & 활주로 개수 & 길이(미터) \\
\hline $\mathrm{BKK}$ & 8,000 & 563,000 & 2 & $60 \times 3,700,60 \times 4,000$ \\
\hline $\mathrm{DMK}$ & 1,552 & 220,683 & 2 & $60 \times 3,700,45 \times 3,500$ \\
\hline $\mathrm{CNX}$ & 578 & 115,315 & 1 & $45 \times 3,000$ \\
\hline HDY & 642 & 35,480 & 1 & $45 \times 3,400$ \\
\hline HKT & 1,188 & 19,375 & 1 & $45 \times 3,050$ \\
\hline CEI & 1,330 & 17,000 & 1 & $45 \times 3,000$ \\
\hline
\end{tabular}

자료: Airports of Thailand Plc., 2019

\section{2. 태국의 지방공항 활용 외래객 유치 전략}

본 연구에서는 태국의 지방공항을 활용한 외국인 관광객 유치 활성화 사례를 중 앙정부, 관광청 및 공항청(공사), 지방자치단체, 해당 공항, 태국 항공사, 여행사 등 관련 기관 및 단체로 구분하여 살펴보았다. 2018년 매경 태국포럼 개최 후 보도된 자료에 따르면, 태국은 지방공항 활성화 및 외래객 유치를 위해 중앙정부에서 다양 한 정책을 시행하고 있다. 태국 정부가 추진 중인 동부경제특구(ECC: Eastern Economic Corridor)프로젝트의 1단계는 돈무앙-수완나폼-우타파오 공항 고속철 을 2019년까지 건설하는 것이다. 이후 2단계 프로젝트에서는 향후 2021년까지 우 타파오 공항 리모델링을 완료하는 것을 목표로 삼고 있다.

태국 정부는 〈국가경제사회개발계획(National Economic and Social Development Plan)> 중에 ‘Thailand 4.0'을 통한 미래 산업 육성 정책을 추진하고 있다. ‘Thailand 4.0’을 통해 육성하고자 하는 산업에는 항공·물류산업이 포함되어 있으 며, 또한 태국 내 3개 공항(돈무앙, 수완나폼, 우타파오 공항) 연결, 우타파오 공항 및 항공정비 등을 통해 항공산업과 관광산업을 동부경제특구 개발의 5 대 우선순위 프로젝트에 두고 있다.6)

6) 이재호(2019), 「최근 태국 경제 현황 및 한국·태국 경제협력 방향」, 대외경제정책연구원. 


\section{가. 지방공항 항공노선 확충}

2019년 10월, 태국 교통부와 태국공항공사에서는 관광활성화를 위한 정책을 발 표하였다. 성수기동안 태국을 방문하는 관광객을 위해 공항료를 인하하고, 전세 항 공편에 대해 착륙료와 주기료를 $50 \%$ 할인하기로 결정하였다. 착륙료와 주기료는 기종과 시간에 따라 1만 6만 바트(한화 약 38만 228만) 사이로 책정된다. 수완나 폼 공항과 돈무앙 공항은 부정기 항공편을 위해 170 회의 슬롯을 따로 확보해두었으 며, 비수기 시간인 자정부터 오전 5시까지도 전세 항공편을 이용할 수 있도록 조치 하였다(Bangkok Post, 2019).

Bangkok Post의 보도자료(15.03)에 따르면, 태국공항공사는 2016년 10월부터 2017년 3월까지 치앙라이 공항과 핫야이 공항을 태국 내 다른 도시들과 연결하기 위해 인센티브를 적용한 바 있다. 정기 항공편과 전세 항공편에 동시에 적용되며, 치앙라이에 있는 매파 루앙 공항과 핫야이 공항을 태국 내 다른 공항과 연결하는 신규 노선을 대상으로 착륙료·주기료 할인, 사무실 렌트와 프로모션 지원금 확대 등의 인센티브를 제공하였으며 치앙라이 공항과 핫야이 공항 신규 노선에 대한 재 정적 지원도 포함되었다.

\section{나. 지방공항 관광수용태세 확립}

태국 정부는 2018년 7월에 발생한 푸켓 선박 침몰 사고로 인해 중국인 관광객이 급격히 줄어들자, 주요 5 개 공항에 중국인 전용 입국 심사대를 개설했다. 수완나폼 공항(18개), 돈무앙 공항(21개), 푸켓 공항(18개), 핫야이 공항(10개), 치앙마이 공 항(8개)에 마련되었으며, 중국어가 가능한 출입국 심사관을 배치하는 등 중국인 관 광객들의 출입국 편의서비스를 제공하였다(교민잡지, 2018).

한편, 태국 국세청은 2019년 경제장관회의에서 외국인 관광객의 편의 제공을 위 한 정책을 발표했다. 현재 수완나폼 공항과 돈무앙 공항에서만 실시되는 VAT 현금 환급 서비스를 치앙마이 공항, 푸켓 공항, 끄라비 공항 등 태국 내 10 개 국제공항으 로 확대할 예정이다. 실제로 부가가치세가 없는 매장에서 관광객 판매가 $10 \%$ 증가 하였다. 또한 5 천 바트(한화 약 19 만원)까지의 물품은 세관원에게 제시할 필요도 없을 것이며, 부가가치세 환급 시 발생하는 비용만큼 더 구매를 하게 될 것이라 기 
대했다(Bangkok Post, 2019).

태국공항공사는 2018년 8월부터 '디지털 에어포츠' 앱을 운영하고 있으며, 회원 가입 시 6개 국제공항7)의 항공권 결제 및 통합 포인트 적립이 가능하다. 태국어와 한국어 포함 총 8개의 언어8)로 서비스를 제공하고 있으며, 항공기 이용객들에게 항 공편 운항 상황을 알려주고, 특정 항공편에 대한 알림 서비스도 받을 수 있다. 공항 내 터미널 지도 안내정보와 위탁 수하물 관련 정보를 제공하고 있으며, 수완나폼 공항을 이용할 경우 해당 앱을 활용하여 수하물 보관을 미리 예약할 수 있다. '디지 털 에어포츠' 앱에서는 보안심사대와 입국심사대의 대기시간도 실시간으로 확인이 가능하다. 심사 관련 도움이나 긴급사항이 있을 경우, 현 위치와 긴급메시지도 보낼 수 있다. 택시 예약도 가능하며, 공항 주차장의 주차가능 대수도 실시간으로 조회할 수 있다. 또한 수완나폼 공항과 돈무앙 공항, 대형쇼핑몰, 호텔에서는 수하물의 크 기나 무게, 거리에 상관없이 수하물 배달(핸즈프리) 예약 기능을 제공하고 있다.

[그림 4-4] 보안 및 입국 심사대 실시간 대기 현황 안내

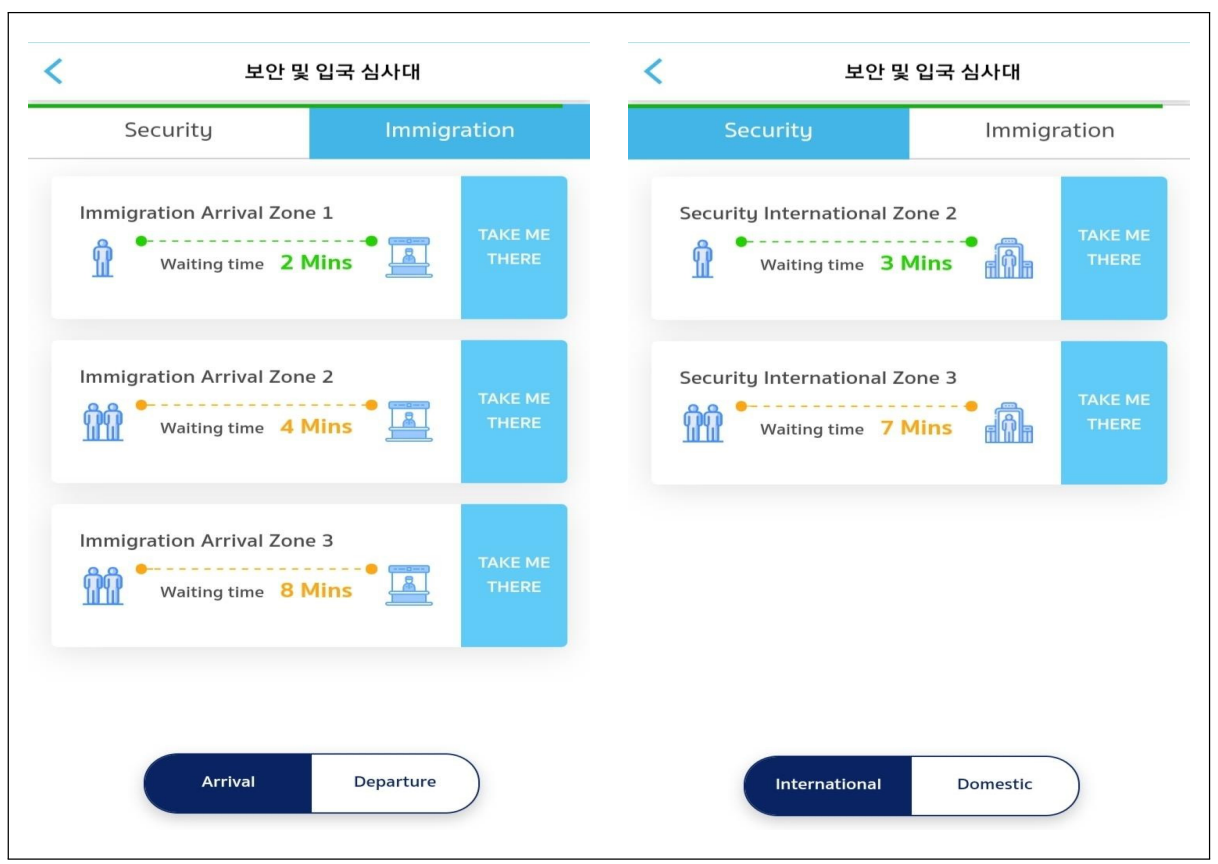

7) 수완나폼 공항, 돈무앙 공항, 치앙마이 공항, 치앙라이 공항, 핫야이 공항, 푸켓 공항

8) 태국어, 한국어, 영어, 중국어, 일본어, 힌디어, 스페인어, 러시아어 
[그림 4-5] 공항 주차가능 대수 현황

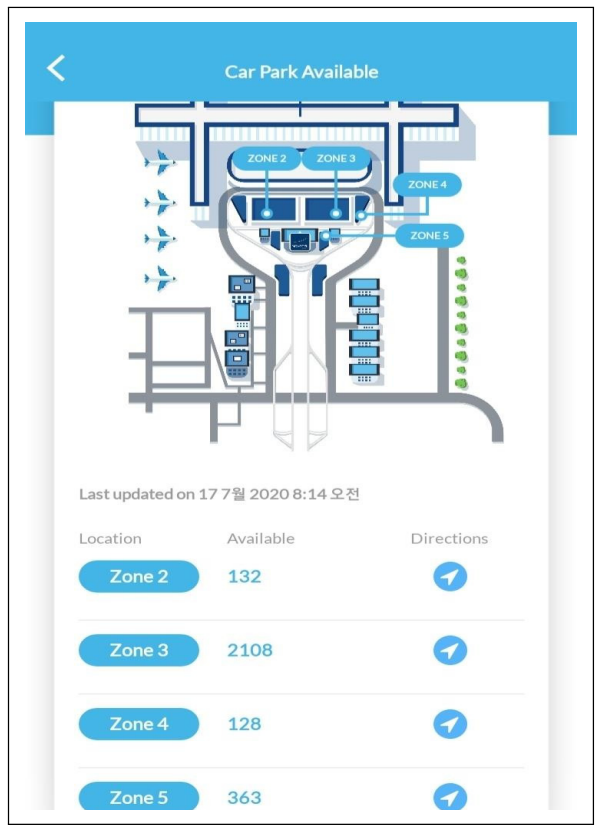

[그림 4-7] 공항 택시 예약 서비스

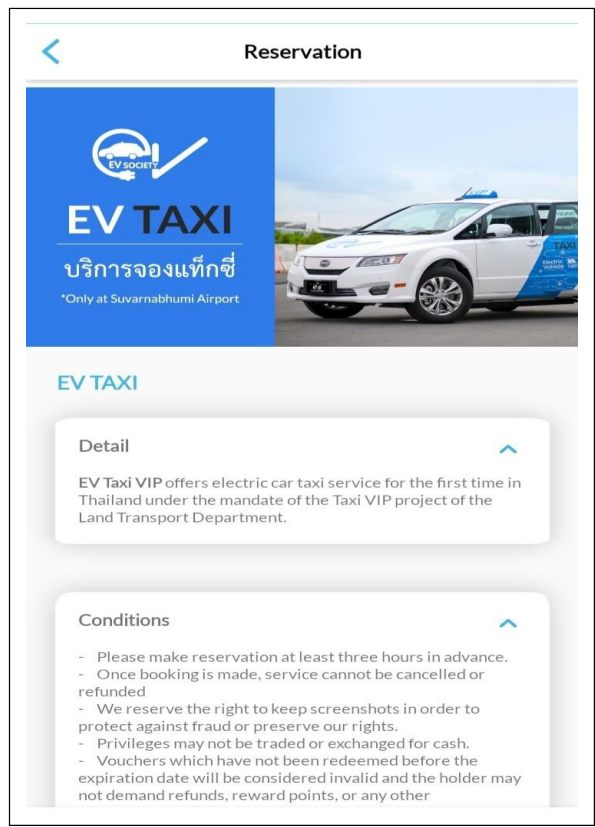

[그림 4-6] 수하물 배달(핸즈프리) 서비스

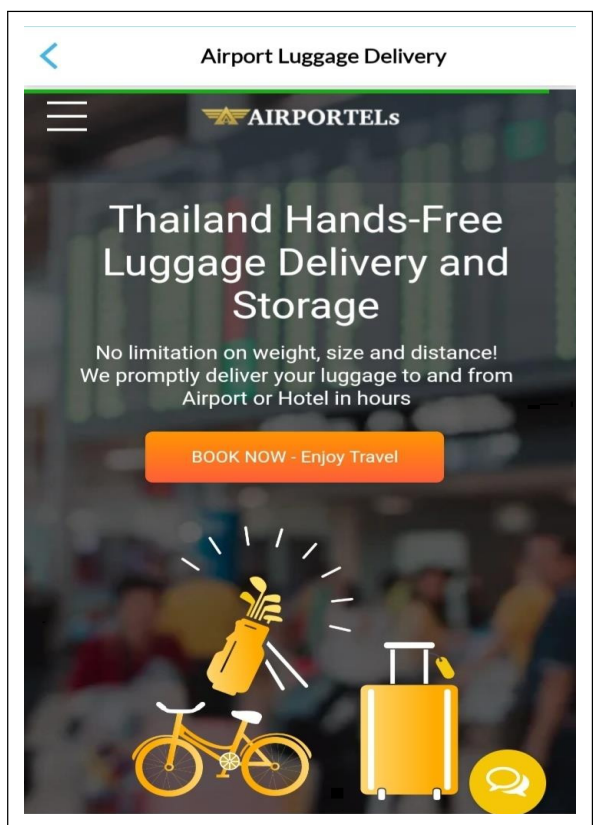

[그림 4-8] 리무진, 수하물, 렌터카 서비스

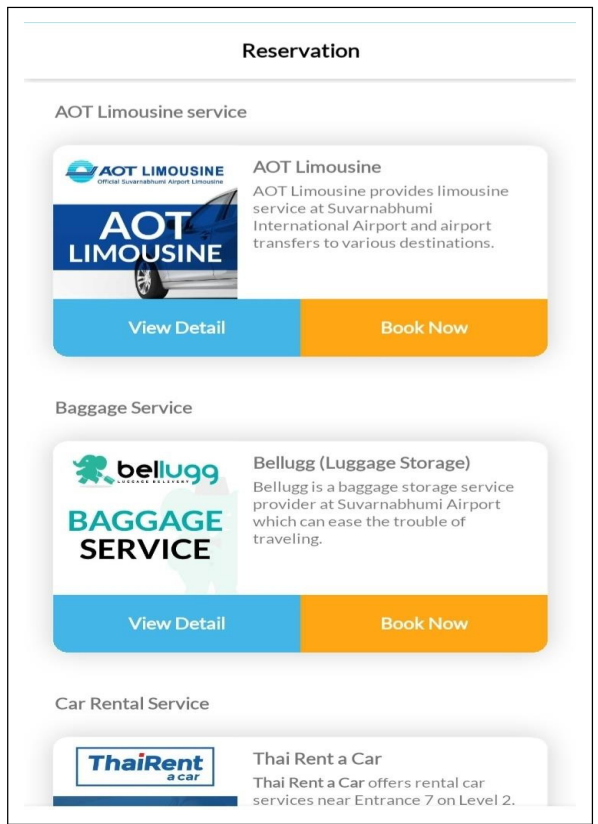




\section{다. 지방공항 연계교통 서비스 개선}

2019년 Grab의 보도자료에 따르면, 태국의 치앙마이 공항은 차량공유업체 Grab과 함께 'GrabTukTuk' 서비스를 시행하고 있다. 기존의 운전기사 고용, 택 시·차량 예약 외 3륜 전기오토바이 예약 기능이 추가되었다. 2019년까지 기존 오토 바이를 모두 전기오토바이로 교체하면서 대기오염 및 소음공해를 줄이는 효과를 가 져왔다.

[그림 4-9] ‘GrabTukTuk’ 3륜 전기오토바이

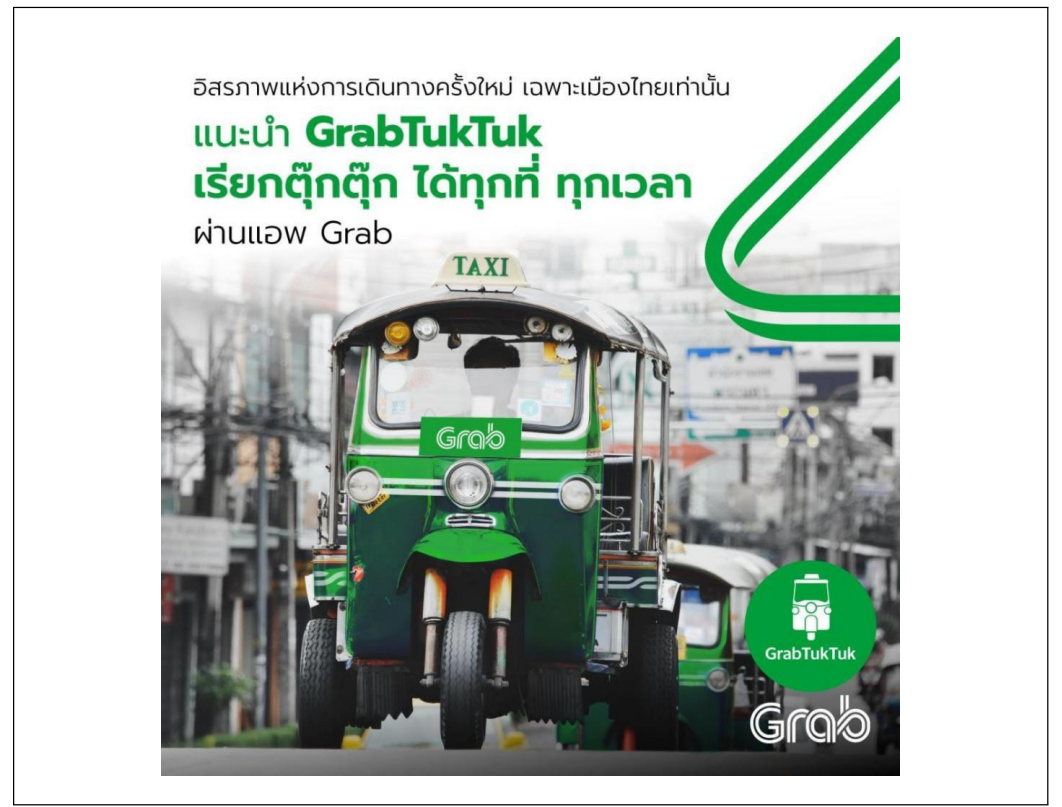

자료: Grab Thailand

또한, 치앙마이 공항은 공항과 치앙마이 도심을 연결하는 셔틀 서비스도 제공하 고 있으며, 총 10 대의 차량으로 2 개의 코스를 운행하고 있다. 제 1 코스는 관광지인 훼이깨우 로드, 님만 사거리, 님만해민 로드를 지나 치앙마이 국제전시컨벤션센터, 왓젯욧 사원 등을 거쳐 치앙마이 공항으로 돌아오는 코스이다. 제 2 코스는 마히돌 로드, 홀리데이 인 호텔, 치앙마이 주지사 거주지(Governor House)와 타페로드를 지나 야시장 일대인 창클란 거리, 나이트 바자르와 로이크로 로드를 거쳐 치앙마이 공항으로 돌아오는 코스로, 정차구역이 치앙마이의 주요 관광지에 집중되어 있다. 
이러한 셔틀 서비스는 치앙마이 공항 국제선 청사에서 매일 오전 8시부터 오후 5시 까지 이용 가능하며, 요금은 40바트(1천500원)이다(Bangkok Post, 2015).

\section{라. 지방공항 외래객 유치 마케팅}

태국관광청은 2016년부터 2018년까지 매년 여왕탄생일인 8월 12일을 기념하고 여성관광객 유치 확대를 목적으로 “여성관광객 유치 캠페인(Women's Journey Thailand Campaign)"을 추진한 바 있다. 캠페인 전용 홈페이지 운영 및 방콕 공 항, 푸켓 공항 등 태국 국제공항 내 여성 전용 입국수속 라인과 특별 항공권 제공 등의 혜택이 주어졌다.

다섯 가지 'Beautiful' 테마(Look, Mind, Shape, Retreat and Experience)를 통한 할인 혜택과 추가 서비스도 제공되었는데, Look은 성형외과, 화장품, 의류 등 이며, Mind는 스파와 명상 체험 등으로 구성되었다. Shape는 무에타이 다이어트, 골프 등이며, Retreat는 스파와 마사지, Experience는 호텔·리조트 및 투어 상품, 항공권 할인 혜택이 포함되었다(한국관광공사, 2016).

또한, 여성 전용 특별 주차구역을 지정하고 출입국 심사 시 여성전용 심사대를 운영하였다. 추가 혜택으로 Siam Discovery 백화점 500바트(한화 약 1만 9천원) 할인권 제공, 방콕항공 국내선 항공권을 최저 1,290 바트(한화 약 5 만원)부터 시작 하는 특별가격에 제공하였으며, 렌터카도 1일 요금 499바트에 이용할 수 있는 혜택 등이 주어졌다. 태국관광청에 따르면, 캠페인 시작 첫 해인 2016년에 태국을 방문 한 여성관광객은 1천 690만 명으로 전년 대비 약 $16.9 \%$ 증가하면서 전체 외국인관 광객의 $52 \%$ 를 차지했는데, 여성관광객 수가 남성관광객 수를 추월한 첫 해이기도 했다(Tourism Authority of Thailand, 2017). 


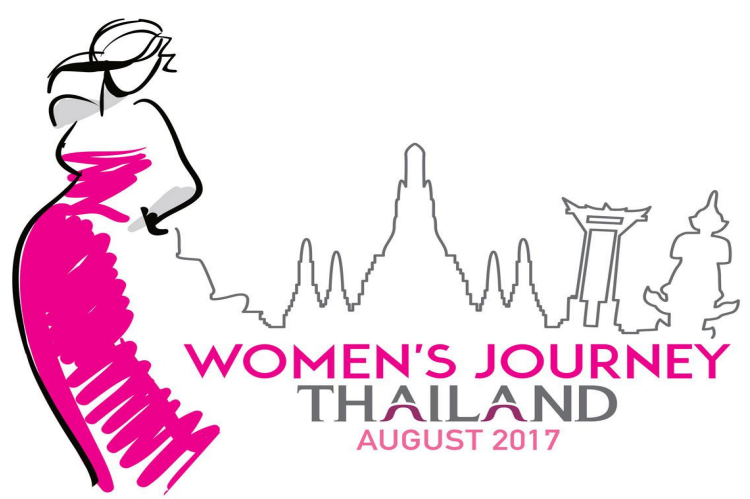

자료: Tourism Authority of Thailand

태국관광청은 2018년 타이항공, 방콕항공, 에바항공 공동으로 전 세계 여행사, 언론매체 등 300여명 대상 메가 팸 투어를 개최하였다. 매년 실시했던 팸투어 규모 를 확대하여 태국의 새로운 마케팅 컨셉(Open to the New Shades of Thailand) 을 경험하고, 새로운 관점을 발견하는 목적으로 진행되었다. 팸투어의 주요 목적지 는 방콕, 펫차 부리, 푸켓, 크라비, 난, 치앙마이 등 14 곳이었으며, 태국의 고유한 지역체험을 중점으로 하고, 주요 타켓은 식도락, 럭셔리, 결혼·신혼여행, 가족여행, 여성여행으로 설정하였다(한국관광공사, 2018).

한편, 태국 자유여행사인 몽키트래블은 제주항공과 제휴해 할인 프로모션을 여러 차례 진행한 바 있다. 2019년 3월 한 달간 김해공항과 무안공항에서 출발하고 제주 항공편을 이용해 태국을 여행 시, 항공권 1 만원 할인쿠폰을 제공하는 프로모션을 진행하였다. 2019년 6월 한 달간 방콕/치앙마이 노선에 한해 왕복항공권 20만원 이상 구매 시 2만원 할인 프로모션도 진행했다. 2019년 11월부터 12월 2일까지 진행한 프로모션은 제주항공의 태국 방콕, 치앙마이 항공권을 구매한 후 제휴코드 를 입력 시, 2 만원 즉시 할인이 적용되었다. 몽키트래블에서는 호텔투어와 교통편 을 예약하고 제주항공 항공권 번호를 인증하면 태국여행 인기상품을 최대 30\%까지 할인혜택을 제공한 바 있다.9)

9) 제주항공 홈페이지 이벤트 자료를 바탕으로 재구성. 
[그림 4-11] 제주항공과 몽키트래블 제휴이벤트

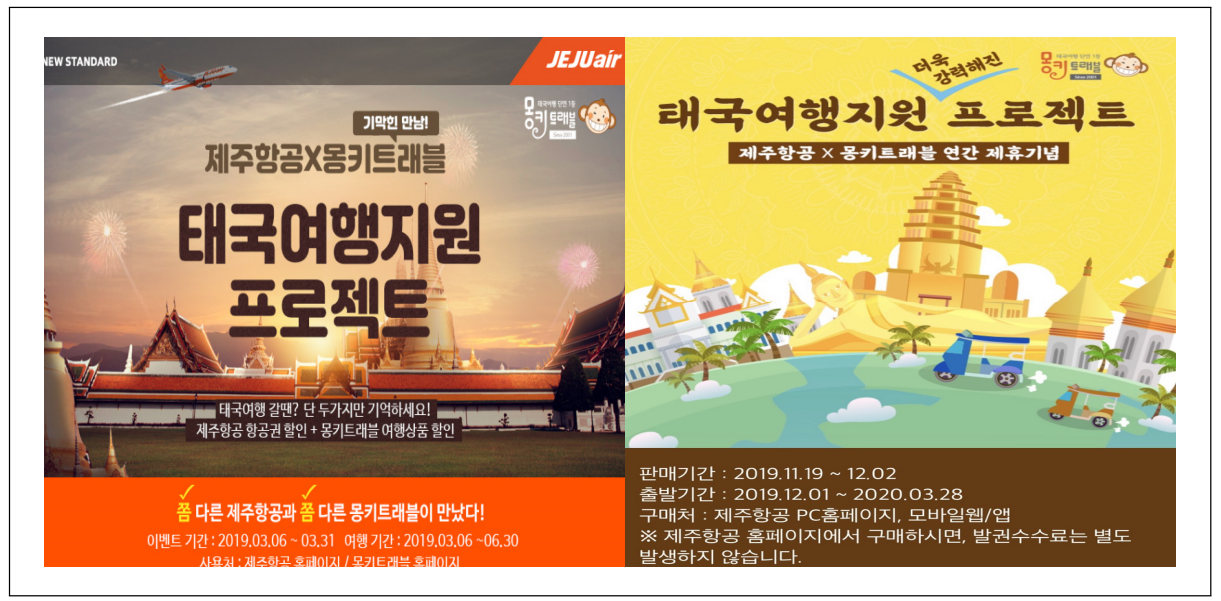

자료: 제주항공 


\section{제4절 호주 사례 조사}

\section{1. 호주의 공항 개요}

호주는 총 276 개의 크고 작은 공항을 보유하고 있으며, 그 중 국가 간 여객과 화물을 수송할 수 있는 요건을 갖춘 국제공항(International Airport)은 15 개가 운 영되고 있다. 이들 15 개의 국제공항은 호주 동부, 서부, 남부, 북부 및 시드니지역 등 5개의 지역군(Region)으로 나누어 운영되고 있는데, 동부지역에 5개, 서부지역 에 2 개, 남부지역에 3 개, 북부지역에 1 개, 시드니지역에 4 개가 각각 운영되고 있다. 호주의 모든 국제공항은 해안을 끼고 있거나 섬(Norfork Island Int'l Airport)에 위치하고 있는 특징이 있다.

\section{가. 국제공항(International Airport) 현황}

- 도심거점형 공항10): 2개 공항

。 시드니 공항(Sydney Airport (SYD))-시드니지역

ㅁ멜버른 공항(Melbourne Airport (MEL))-남부지역

- 지역연계형 공항 11$): 13$ 개 공항

- 동부(5개), 서부(2개), 남부(2개), 북부(1개), 시드니지역(3개)

으브리즈번 공항(Brisbane Airport (BNE))-동부지역

。 케언스 공항(Cairns Airport (CNS))-동부지역

올드코스트 공항(Gold Coast Airport (OOL))-동부지역

10) 한 나라의 수도 또는 제2의 도시에 위치한 대규모 관문공항(gateway airport)으로 해당국가로 해외에서 여객과 화물을 수송하는 대표 공항이면서 또 다른 국내 나 해외 공항으로 화객을 이원 수송하는 공항을 칭함.

11) 지역을 대표하는 중소형 공항으로 국내외 소규모 도시와 연계하여 화객을 수송하는 공항을 일컬음. 
- 선샤인 코스트 공항(Sunshine Coast Airport (MCY))-동부지역

- 타운즈빌 공항(Townsville Airport (TSV))-동부지역

。퍼스 공항(Perth Airport (PER))-서부지역

- 포드 해드랜드 공항(Port Hedland Airport (PHE))-서부지역

- 애들래이드 공항(Adelaide Airport (ADL))-남부지역

아아랄론 공항(Avalon Airport (AVV))-남부지역

아다뉜 공항(Darwin Airport (DRW))-북부지역

- 캔버라 공항(Canberra Airport (CBR))-시드니지역

- 뉴캐슬 공항(Newcastle Airport (NTL))-시드니지역

- 노포크 아일랜드 공항(Norfork Island Airport (NLK))-시드니지역

[그림 4-12] 호주의 국제공항 현황

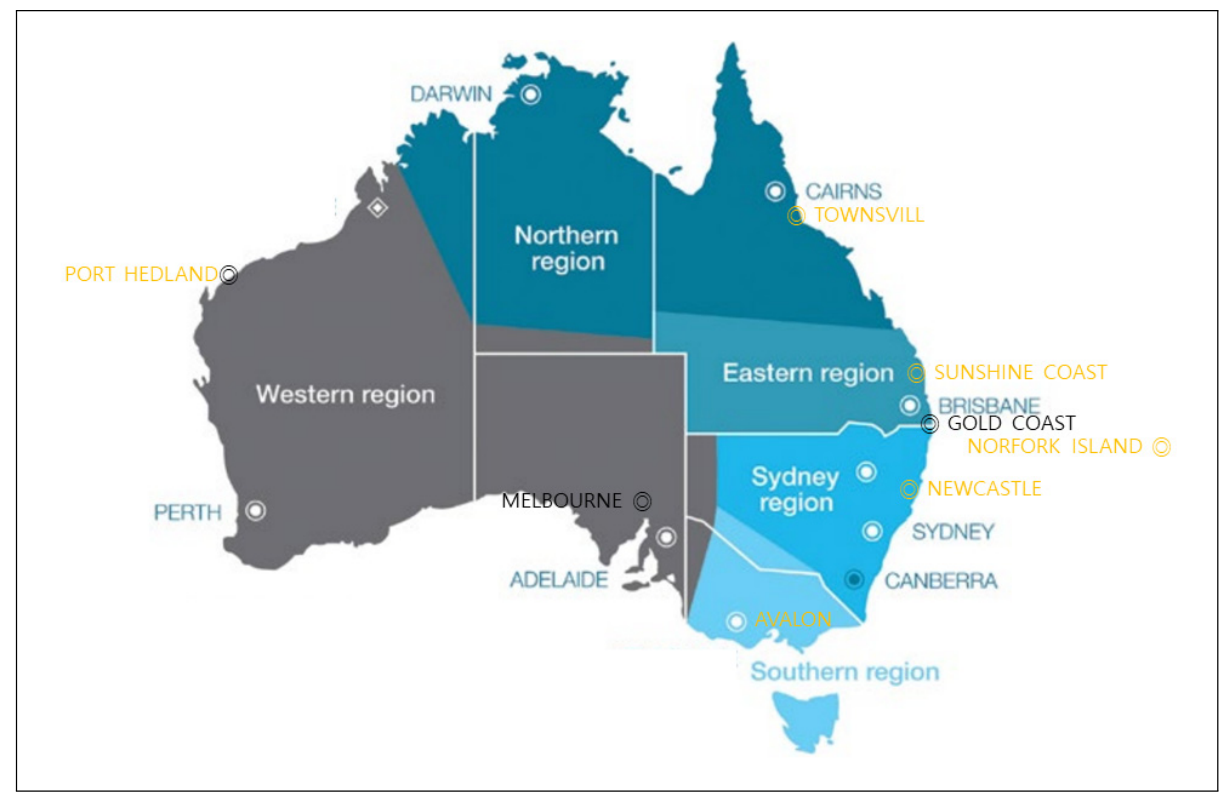

자료: Australian Government, Civil Aviation Safety Authority, Annual Report 2018-19 


\section{나. 주요 공항의 국제선 운항 현황}

1) 연간 국제선 운항편수 현황

(1) 주요 공항의 연간 항공기 운항편수 증가율

- 2013년 2019년 7년간 평균 증가율: 3.2\%

- 도시거점형 공항: 시드니 공항(3.0\%), 멜버른 공항(5.7\%)

- 지역연계형 공항: 브리즈번 공항(3.9\%), 퍼스 공항(-0.5\%)

그 외 4 개 공항(- $-1.1 \%)$

- 2 개의 도심거점형 공항의 7 년간 평균 증가율이 $4.3 \%$ 인데 반하여, 지역연계 형 공항의 평균 증가율은 $0.9 \%$ 로 항공기 운항편수가 수도권 공항 중심으로 안정적으로 증가하는데 반해, 지역공항은 점진적으로 축소되는 경향을 볼 수 있음

(2) 도심거점형 공항과 지역연계형 공항의 평균 항공기 운항편수

- 도심거점형 공항인 시드니 공항(74.6천회)과 멜버른 공항(45.1천회)의 7년간 연 평균 운항편수가 119.7 천회로 호주 전체 국제공항 운항편수 193.5 천회 대 비 61.9\%를 점유함

- 지역연계형 공항의 국제선 항공기 운항편수는 73.1 천회로 전체 국제선 운 항편수 대비 절반에 못 미치는 39.1\%를 점유함

- 이는 $60 \%$ 이상이 2 개의 도심거점형 공항에 편중되어 집중되고 있는 것을 보여줌

(3) 공항별 항공기 운항편수 점유비

- 2 개의 도심거점형 공항과 지역연계형 공항에 편중되고 있음

- 도심거점형 공항: 시드니 공항(38.6\%)과 멜버른 공항(23.3\%)

- 2개 지역연계형 공항: 브리즈번 공항(16.2\%)과 퍼스 공항(11.6\%)

- 기타 5개 지역연계형 공항: $10.3 \%$

- 4 개의 도심거점형 공항과 지역연계형 공항의 항공기 운항편수 점유비가 $89.7 \%$ 로 절대적인 수치를 나타내고 있음 
〈표 4-12〉호주 주요 국제공항의 연간 항공기 운항 현황

(단위: 1,000 회, \%)

\begin{tabular}{|c|c|c|c|c|c|c|c|c|c|}
\hline \multirow{2}{*}{ 공항 } & \multicolumn{3}{|c|}{2015} & \multicolumn{3}{|c|}{2017} & \multicolumn{3}{|c|}{2019} \\
\hline & $\mathrm{IN}-\mathrm{B}$ & OUT-B & TOTAL & IN-B & OUT-B & TOTAL & IN-B & OUT-B & TOTAL \\
\hline SYD & 34.3 & 34.2 & 68.5 & 39.0 & 38.9 & 77.9 & 40.9 & 40.9 & 81.9 \\
\hline MEL & 21.2 & 21.2 & 42.3 & 23.4 & 23.4 & 46.9 & 26.0 & 26.0 & 52.0 \\
\hline BNE & 14.6 & 14.6 & 29.1 & 16.2 & 16.2 & 32.4 & 17.6 & 17.6 & 35.2 \\
\hline PER & 10.9 & 10.8 & 21.7 & 11.2 & 11.1 & 22.3 & 10.8 & 10.8 & 21.7 \\
\hline$A D L$ & 2.1 & 2.1 & 4.3 & 2.4 & 2.4 & 4.8 & 2.7 & 2.7 & 5.4 \\
\hline $\mathrm{OOL}$ & 2.6 & 2.6 & 5.1 & 3.3 & 3.3 & 6.7 & 2.5 & 2.5 & 5.0 \\
\hline CNS & 2.8 & 2.8 & 5.6 & 2.9 & 2.9 & 5.8 & 2.4 & 2.4 & 4.9 \\
\hline CBR & 0.0 & 0.0 & 0.0 & 0.4 & 0.4 & 0.8 & 0.7 & 0.7 & 1.5 \\
\hline DRW & 1.4 & 1.4 & 2.8 & 1.4 & 1.4 & 2.9 & 1.1 & 1.1 & 2.1 \\
\hline 9개 합계 & 89.8 & 89.6 & 179.4 & 100.2 & 100.2 & 200.4 & 104.9 & 104.9 & 209.8 \\
\hline 전체 수송 & 90.0 & 89.8 & 179.8 & 100.6 & 100.6 & 201.2 & 105.8 & 105.9 & 211.7 \\
\hline 9개 (\%) & 99.8 & 99.8 & 99.8 & 99.6 & 99.6 & 99.6 & 99.1 & 99.1 & 99.1 \\
\hline \multirow{2}{*}{ 공항 } & \multicolumn{4}{|c|}{ 9개 주요공항 연 평균 운항횟수 } & 9개 공흔 & 별 연간 둔 & 항횟수 & 점유비 & 연평균 \\
\hline & $\mathrm{IN}-\mathrm{-}$ & & UT-B & TOTAL & IN-B & OUT- & & TOTAL & 증가율 \\
\hline SYD & 37.3 & & 37.3 & 74.6 & 38.6 & 38.5 & & 38.6 & 3.0 \\
\hline MEL & 22. & & 22.5 & 45.1 & 23.3 & 23.3 & & 23.3 & 5.7 \\
\hline BNE & 15.6 & & 15.7 & 31.2 & 16.1 & 16.2 & & 16.2 & 3.9 \\
\hline PER & 11.2 & & 11.2 & 22.5 & 11.6 & 11.6 & & 11.6 & -0.5 \\
\hline ADL & 2.4 & & 2.4 & 4.9 & 2.5 & 2.5 & & 2.5 & 3.0 \\
\hline $\mathrm{OOL}$ & 2.8 & & 2.8 & 5.5 & 2.9 & 2.9 & & 2.9 & 2.6 \\
\hline CNS & 2.7 & & 2.7 & 5.5 & 2.8 & 2.8 & & 2.8 & -1.5 \\
\hline CBR & 0.5 & & 0.5 & 1.0 & 0.3 & 0.3 & & 0.3 & - \\
\hline DRW & 1.4 & & 1.4 & 2.9 & 1.5 & 1.5 & & 1.5 & -8.5 \\
\hline
\end{tabular}

자료: Australian Government, Department of Infrastructure, Transport, Cities and Regional Development, Statistical Report 2014 2019 
2) 주요 공항의 국제여객 수송 현황

(1) 9 개 주요 국제공항의 연간 국제여객 수송 증가율

- 2013년 2019년 7년간 평균 증가율: $5.2 \%$

- 도시거점형 공항: 시드니 공항(4.6\%), 멜버른 공항(7.6\%)

- 지역연계형 공항: 브리즈번 공항(5.5\%), 퍼스 공항(1.8\%)

그 외 4 개 공항 $(2.4 \%)$

- 2 개의 도심거점형 공항의 7 년간 평균 증가율이 $6.1 \%$ 인데 반하여, 지역연계 형 공항의 평균 증가율이 $3.8 \%$ 로 항공기 운항편수 점유비에 비하여 편차가 다소 완화됨. 이는 지방공항 중심으로 중대형기재가 집중적으로 투입된 결 과라고 추측할 수 있음

(2) 9 개 주요 국제공항의 평균 국제여객 수송 현황

- 도심거점형 공항인 시드니 공항(15.0백만명)과 멜버른 공항(9.5백만명)의 7년 간 연 국제여객 수송이 24.5 백만 명으로 호주 전체 국제공항의 국제여객 수송 37.2백만 명 대비 65.9\%를 점유함

- 지역연계형 공항 7 개의 수송 규모가 12.7 백만 명으로 $34.1 \%$ 를 점유함

- 이는 2 개의 도심거점형 공항의 항공기 운항편수가 $39.1 \%$ 인데 반하여, 국제여 객 수송에 있어 도심공항에 집중되는 것이 다소 완화되고 있다고 볼 수 있음

(3) 공항별 국제여객 수송 점유비

- 2 개의 도심거점형 공항과 지역연계형 공항에 집중

- 도심거점형 공항: 시드니 공항(40.3\%)과 멜버른 공항(25.6\%)

- 2개 지역연계형 공항: 브리즈번 공항(14.8\%)과 퍼스 공항(11.4\%)

- 기타 5 개 지역연계형 공항: $7.6 \%$

- 2 개의 도심거점형 공항의 국제여객 수송 점유비가 $65.9 \%$ 로 도심공항 항공 기 운항편수 점유비 $61.9 \%$ 대비 다소 높은 것으로 나타나 대형기재가 도심 공항에 집중적으로 운항되고 있는 것을 볼 수 있음

- 4개의 도심거점형 공항과 지역연계형 공항의 국제여객 수송 점유비가 $92.4 \%$ 로 도심 대형공항에 여객수송이 집중되고 있는 것을 볼 수 있음 
〈표 4-13〉 호주 9개 국제공항의 국제여객 수송 현황

(단위: 100만명, \%)

\begin{tabular}{|c|c|c|c|c|c|c|c|c|c|}
\hline \multirow{2}{*}{ 공항 } & \multicolumn{3}{|c|}{2015} & \multicolumn{3}{|c|}{2017} & \multicolumn{3}{|c|}{2019} \\
\hline & IN-B & OUT-B & TOTAL & IN-B & OUT-B & TOTAL & $\mathrm{IN}-\mathrm{B}$ & OUT-B & TOTAL \\
\hline SYD & 7.0 & 6.9 & 13.9 & 8.1 & 8.0 & 16.0 & 8.5 & 8.4 & 16.9 \\
\hline MEL & 4.5 & 4.4 & 8.9 & 5.2 & 5.1 & 10.3 & 5.7 & 5.6 & 11.3 \\
\hline BNE & 2.6 & 2.6 & 5.2 & 2.9 & 2.9 & 5.7 & 3.2 & 3.2 & 6.4 \\
\hline PER & 2.1 & 2.1 & 4.2 & 2.2 & 2.2 & 4.4 & 2.2 & 2.2 & 4.4 \\
\hline$A D L$ & 0.4 & 0.4 & 0.9 & 0.5 & 0.5 & 1.0 & 0.6 & 0.6 & 1.1 \\
\hline $\mathrm{OOL}$ & 0.5 & 0.5 & 0.9 & 0.6 & 0.5 & 1.1 & 0.5 & 0.5 & 0.9 \\
\hline CNS & 0.3 & 0.3 & 0.5 & 0.3 & 0.3 & 0.7 & 0.3 & 0.3 & 0.7 \\
\hline $\mathrm{CBR}$ & 0.0 & 0.0 & 0.0 & 0.0 & 0.0 & 0.1 & 0.0 & 0.0 & 0.1 \\
\hline DRW & 0.1 & 0.1 & 0.3 & 0.1 & 0.1 & 0.3 & 0.1 & 0.1 & 0.3 \\
\hline 9개 합계 & 17.5 & 17.3 & 34.8 & 19.9 & 19.6 & 39.5 & 21.1 & 20.9 & 42.1 \\
\hline 전체 수송 & 17.5 & 17.3 & 34.9 & 19.9 & 19.7 & 39.6 & 21.4 & 21.2 & 42.5 \\
\hline 9개 (\%) & 99.9 & 99.9 & 99.9 & 99.8 & 99.8 & 99.8 & 98.9 & 99.0 & 98.9 \\
\hline \multirow{2}{*}{ 공항 } & \multicolumn{4}{|c|}{ 9개 주요공항 연 평균 국제여객 수송량 } & 9개 공 & 항별 국제 & 여객 수훈 & 족 점유비 & 연평균 \\
\hline & $\mathrm{IN}-\mathrm{E}$ & & OUT-B & TOTAL & IN-B & OU & T-B & TOTAL & 증가율 \\
\hline SYD & 7.5 & & 7.5 & 15.0 & 40.2 & 40 & & 40.3 & 4.6 \\
\hline MEL & 4.8 & & 4.7 & 9.5 & 25.6 & 25 & & 25.6 & 7.6 \\
\hline BNE & 2.8 & & 2.7 & 5.5 & 14.8 & 14 & & 14.8 & 5.5 \\
\hline PER & 2.1 & & 2.1 & 4.3 & 11.5 & 11 & & 11.4 & 1.8 \\
\hline ADL & 0.5 & & 0.5 & 1.0 & 2.6 & 2 & & 2.6 & 6.3 \\
\hline $\mathrm{OOL}$ & 0.5 & & 0.5 & 1.0 & 2.6 & 2 & & 2.6 & 1.7 \\
\hline CNS & 0.3 & & 0.3 & 0.6 & 1.6 & 1. & & 1.6 & 5.2 \\
\hline CBR & 0.0 & & 0.0 & 0.1 & 0.1 & 0 & & 0.1 & - \\
\hline DRW & 0.1 & & 0.1 & 0.3 & 0.7 & 0 & 8 & 0.7 & 5.1 \\
\hline
\end{tabular}

자료: Australian Government, Department of Infrastructure, Transport, Cities and Regional Development, Statistical Report 2014 2019 


\section{2. 호주의 지방공항 활용 외래객 유치 전략}

호주 지방공항을 활용한 외국인관광객 유치 전략 사례를 중앙정부, 관광청 및 공 항청(공사), 지방자치단체, 해당 공항, 호주 항공사, 여행사 등 6개 기관 및 단체들 로 구분하여 살펴보았다.

\section{가. 지방공항 항공노선 확충}

2015년 11월 뉴사우스웨일스 주정부는 중국인 관광객 유치를 위해 중국항공사 인 샤먼항공과 $\mathrm{MOU}$ 를 체결한 바 있다. 뉴사우스웨일스 주 관광이벤트기관인 ‘Destination NSW' 는 투자 및 마케팅 파트너 십을 통해 호주 관광 홍보 및 중국시드니 간 직항노선 취항을 추진하게 되었다. 중국은 뉴사우스웨일스 주에서 가장 큰 인바운드 시장으로 2014년 기준 52만 6천명의 중국인 관광객이 방문하여 약 20 억 달러를 소비한 것으로 나타났다. 중국 샤먼-시드니 간 직항노선을 통해 매년 1 억3500만 달러를 추가로 창출할 수 있게 되었고, 마케팅 협력, 관광분야 교육과 훈련, 미디어 협력을 위한 파트너십도 지속적으로 유지하고 있다(Destination NSW Press Release, 2015).

\section{나. 지방공항 관광수용태세 확립}

호주 정부는 '프리미엄 승객 제도'를 도입하여 일정 금액을 더 지불하면 공항에서 대기하지 않고 바로 심사를 받을 수 있는 방안을 발표했다. 호주 정부에 따르면, 공 항 대기열이 '세관' 항목 중 불만족 사항 1 위였으며, 공항 이용객들의 평균 대기시 간이 90분 정도로 길게 나타났다. 호주의 항공사들도 이 제도에 긍정적인 입장을 보였으며, 호주 정부는 더 많은 고소득 외국인 관광객을 유치하는데 효과가 있을 것으로 기대했다(The Sydney Morning Herald, 2016).

또한 호주 이민부 발표에 따르면 호주 공항에 얼굴, 홍채나 지문과 같은 생체인식 시스템을 2017년부터 도입하였다. 호주를 방문하는 외국인 관광객들은 세관검사 때문에 오랜 시간 기다리지 않고, 입국신고서가 폐지되어 여권을 제시할 필요 없이 생체 인식 전자시스템을 이용할 수 있다. 2017년 7월 뉴질랜드와 싱가포르 노선을 
대상으로 시범 운영하였으며, 11 월에는 호주 주요 공항에서도 확대 도입되었다.

한편, 호주 멜버른 공항은 제4터미널에 옷가게, 음식점 등 30 여개 다양한 매장이 입점해 공항 이용객들의 선택의 폭이 넓어지게 되었다. 특히, 멜버른이 패션의 도시 로 부상하고 있는 만큼 빅토리아 시크릿, 호주 대표 의류잡화 브랜드인 Country Road, 화장품 브랜드인 AMUSE 뷰티스튜디오 등의 패션 관련 매장이 입점하였다. 이 외에 아시아 음식점 등 식음료 매장과 멜버른 지역 음식점도 입점하였으며, 대규 모 입점을 통해 멜버른 공항을 쇼핑의 장으로 조성하고 공항의 명성을 높이는 효과 를 기대할 수 있었다(한국관광공사, 2015).

호주 캔버라 공항 '캔버라 예술축제(Contour 556)'와 파트너 십을 체결하였다. 공항 터미널과 비즈니스 파크에 14 개의 공공예술작품을 전시하였으며, 독일 작가 Jorg Plickat의 6가지 공공예술작품인 'Sphere'도 선보였다. 캔버라 공항은 캔버 라 지역사회에 대한 노력과 문화예술에 대한 관심을 토대로 3 만 달러 상당의 수상 작품을 전시하고, Contour556을 지원하고 있다. 지방공항과 문화예술의 파트너 십으로 호주 캔버라 공항을 찾는 방문객들이 증가하는 효과를 기대했다(Canberra Airport News, 2018).

[그림 4-13] 호주 캔버라 공항에 설치된 작품

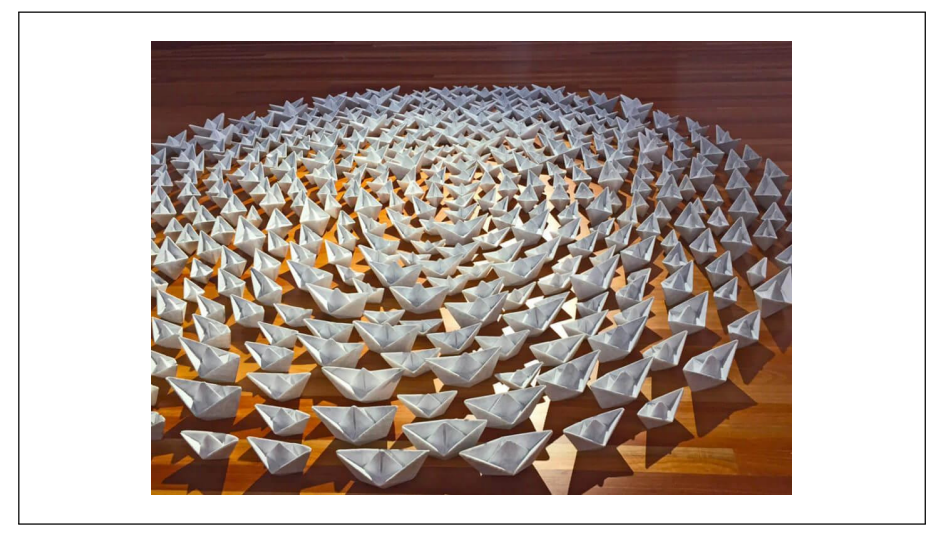

자료: Canberra Airport

호주 브리즈번 공항에 따르면, 브리즈번 투자와 관광·컨벤션 등을 담당하는 기관 인 브리즈번 마케팅(Brisbane Marketing)과 함께 북미지역 관광마케팅팀을 조직 하였다. 주요 국제시장에서 브리즈번의 인지도를 높이기 위해 파트너 십을 맺고 전 
문기관을 설립한 것이다. 이는 2020년 중반에 새 활주로가 개통되고, 브리즈번-시 카고 직항노선과 브리즈번-샌프란시스코 직항노선도 취항을 준비하고 있기 때문이 다. 브리즈번 마케팅과 브리즈번 공항은 미국 관광객들이 호주 퀸즐랜드로 입국하 도록 북미시장에서 인지도를 높일 계획이다.

또한 브리즈번 공항은 지역 스타트업 기업이면서 디지털화폐 결제회사인 TravelbyBit 과 함께 디지털화폐로 공항을 이용할 수 있도록 파트너 십을 체결하였다. 비트코인, 대시, 이더리움 등의 디지털화폐를 블록체인 결제시스템을 통해 공항 내 식음료 매 장, 쇼핑몰에서도 결제할 수 있다. 디지털화폐 결제는 개인정보를 비공개로 보호하 고 중개업체를 없애 거래 수수료를 낮추며 전송 속도도 빠르게 하는 효과가 있다. 브리즈번 공항은 공항 디지털 혁신의 선두를 목표로 하고 있으며, 지역사회와 지 역비즈니스도 지원해나갈 계획을 갖고 있다(Brisbane Airport Newsroom, 2018).

[그림 4-14] TravelbyBit의 브리즈번 공항 홍보 포스터

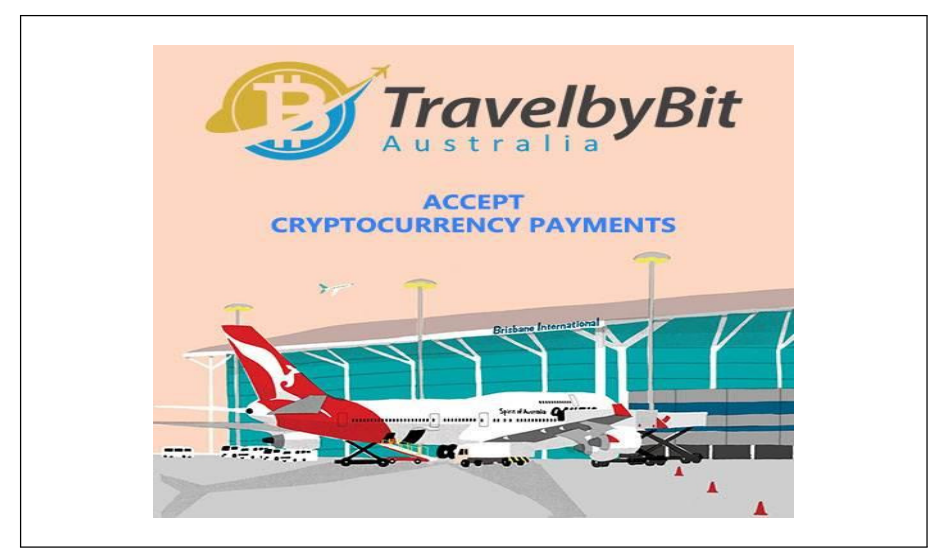

자료: VARIndia

호주 멜버른 공항에서는 제4터미널을 제트 스타나 타이거 항공 같은 저비용 항공 사(LCC)전용 터미널로 운영하고 있다. 싱가포르 창이공항과 말레이시아 쿠알라룸 푸르 공항의 'Budget Terminal'과 함께 설계되었으며, 호주 내 공항 중 멜버른 공 항이 최초로 도입하였다. 제 $1,2,3$ 터미널과 이어지는 통로가 있어 15 분 이내로 터미 널 간 이동할 수 있으며, 셀프 체크인 키오스크와 자동 수하물 위탁 서비스와 보관 
서비스도 이용할 수 있다. 특히 터미널 바로 앞에는 '교통허브 구역'이 위치하고 있 어 터미널 입구에서 나가면 주차장, 택시 승차장에 가기 편리하고 버스 환승, 하차 및 픽업 서비스도 근처에서 가능하다. 하지만 Budget 터미널인 만큼 쇼핑, 약국, 식음료, $\mathrm{Wi}-\mathrm{Fi}$ 서비스 등 일반 터미널에 비해 편의 시설과 서비스 제공은 다소 부 족하다.12)

\section{다. 지방공항 연계교통 서비스 개선}

호주 정부는 우버에어(Uber Air)와 함께 지상교통 체증을 해소하고 도심교통에 비행을 도입해 새로운 모빌리티를 구상하는 목적으로 전기 비행택시를 2020년에 시범 운행하고, 2023년에 상용화할 계획을 발표했다. 이 사업이 진행될 시범 도시 로는 호주 멜버른이 선정되었다. 멜버른 시내에서 공항까지 거리는 $19 \mathrm{~km}$ 로 차로 이동 시 25 분이 소요되지만, 교통 혼잡시 1 시간이 소요되는 것으로 나타났다. 우버 에어는 전기 비행택시로 멜버른 도심에서 공항까지 10 분 만에 갈 수 있을 것으로 전망하고 있다(Uber Korea Newsroom, 2019).

[그림 4-15] Uber Air 전기 비행택시

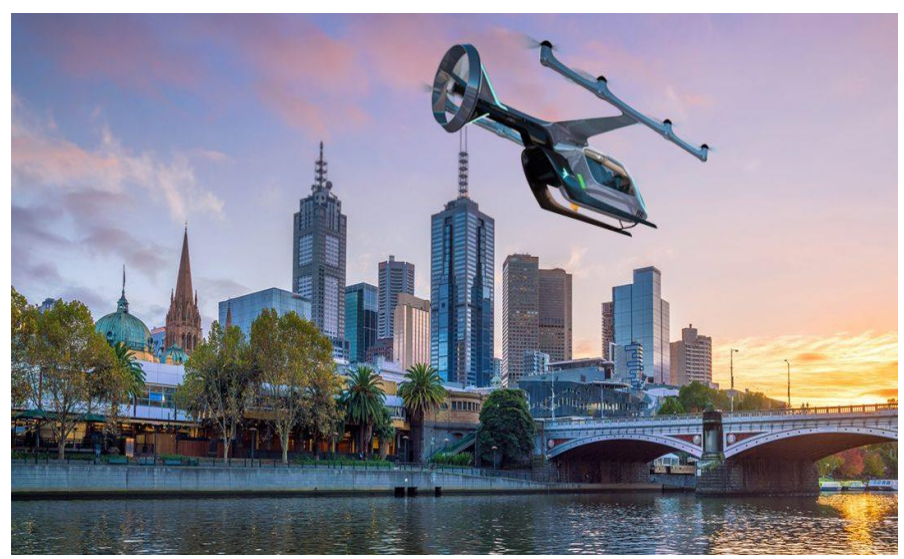

자료: Uber Korea

12) Melbourne Airport Terminal 4 홈페이지 세부내용 재정리. 
또한 호주 멜버른 툴라마린 공항은 공항에서 멜버른 시내까지 운영하는 'Sky Bus'를 운영하고 있다. 공항이 시내와 거리가 떨어져 있는 편인데, Sky Bus를 이용 하면 멜버른 시내와 숙소에 편리하게 이동할 수 있다. 툴라마린 공항에서 나오면 승차장이 바로 보이며, 티켓은 편도 19달러(한화 약 2만 3천원), 왕복 36달러(한화 약 4 만 2천원)이다. 1층 버스와 2 층 버스가 있는데, 1 충 버스는 1 층 공간이 넓어 캐리어를 두는데 불편함이 없고, 2 층 버스는 캐리어를 2층에 보관할 수 있다. 환승 시에도 정확하게 환승 정류장에 내려주기 때문에, 환승 편을 타기 위해 별도로 이동 할 필요가 없다. 예약 시스템을 연계한 호텔들도 있어 호텔에서도 Sky Bus 티켓을 예매할 수 있다.13)

\section{라. 지방공항 외래객 유치 마케팅}

호주정부관광청에서는 2014년에 버진 오스트레일리아와 함께 3년간 2천만 호주 달러의 마케팅 파트너 십을 체결한 바 있다. 2015년에 미국과 뉴질랜드 관광객 대 상 홍보비용으로 1 천만 호주달러를 공동으로 지출하고, 3 백만 호주달러를 미국과 뉴질랜드에 마케팅 하는데 사용했다. 210만 호주달러는 각각의 스폰서 협정을 위해 추가로 지출되었다. 미국과 뉴질랜드는 호주 전체 방문객 중 4분의 1 을 차지하는 주요 인바운드 시장으로, 관광청과 항공사의 마케팅 파트너 십을 통해 인바운드 관 광 활성화 효과가 있었다.

또한 버진 오스트레일리아는 'Mystery Break' 상품을 운영해 공항 이용률을 높 이고 있다. 'Mystery Break'는 특별 휴가 패키지 상품으로, 오스트레일리아 목적지 중 도착지를 랜덤으로 지정하여 판매하고 있다. 최종 도착지는 여행 시작 하루 전에 공개되며, 출발일 기준 2주 전에 상품을 예약할 수 있다. 패키지는 왕복 항공운임, 4 5성급 숙박시설, 수하물 보험과 세금 혜택 등이 포함되어 있다. 출발은 시드니 공항과 멜버른 공항, 브리즈번 공항, 애들레이드 공항, 퍼스 공항에서 할 수 있으며, 도착은 멜버른 공항, 시드니 공항 등 주요 공항을 포함해 발리나 공항, 브룸 공항, 다윈 공항, 론서스턴 공항, 타운스빌 공항 등 여러 지방공항-14)에 도착할 수 있다.15)

13) Skybus 홈페이지 세부내용 재정리.

14) 도착 공항에는 애들레이드 공항, 골드 코스트 공항, 브리즈번 공항, 선샤인 코스트 공항, 시드니 공항, 퍼스 공항, 켄버라 공항, 멜버른 공항, 케언즈 공항, 발리나 공항, 뉴캐슬 공항, 브룸 공항, 다윈 공항, 
[그림 4-16] Mystery Breaks 로고

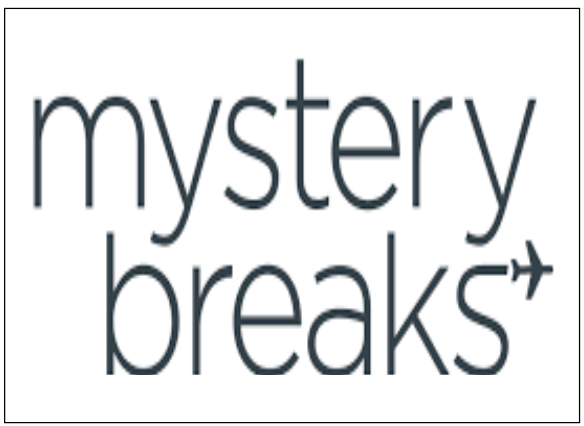

[그림 4-17] Mystery Breaks 도착 공항

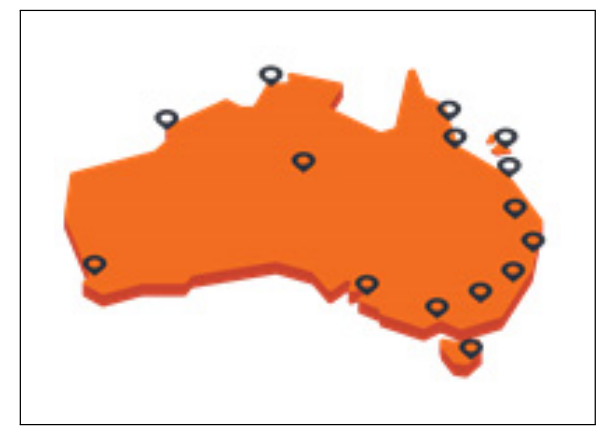

호바트 공항, 론서스턴 공항, 타운스빌 공항, 해밀턴아일랜드 공항 등이 있다.

15) Mystery Breaks 홈페이지 세부내용 재정리. 


\section{제5절 분석결과 및 시사점}

\section{가. 공항 세일즈 정책 및 LCC와 외항사 유치}

일본의 경우 ‘방일여행객 유치 지원공항' 인정제도를 시행하고 있으며 지방공항 의 국제노선 신규취항 및 증편을 위한 공항 세일즈 정책을 추진하고 있다. 특히 일 본정부관광국(JNTO)에서는 해외지사를 활용하여 공항 세일즈에 관한 정보를 제공 하고 있으며 국제적인 전문상담회 등 참가를 지원하고 있다. 일본 간사이공항은 외 국국적 항공사가 전체 운항편수의 약 $87.5 \%$ 를 차지하고 있어 우리나라 김해공항과 큰 대조를 보이고 있다. 간사이공항에서 운항 중인 전체 항공사 중에 LCC 비율은 약 $40.7 \%$ 로 파악되며, 한국노선의 경우 LCC가 전체 운항편수의 약 $73.5 \%$ 로 매우 높은 비중을 차지하고 있다. 중국, 한국을 제외한 기타 아시아노선의 경우 홍콩과 대만노선이 활발히 운항중이다.

\section{나. 개별여행객을 위한 공항 렌터카 편의 개선}

일본 지방공항 가운데 사가공항의 경우 국제선 체크인 카운터에 통역인력 배치 등 외국어 안내 서비스를 강화하고 있으며, 공항 연계교통 개선을 위해 리무진 택시 도입, 렌트카 할인 캠페인 등을 시행한 바 있다. 또한 요나고 공항의 경우 동일한 항공사가 취항 중인 인근 지자체와 협력하여 해외 미디어 및 블로거 초청 팸투어를 실시하고, 개별여행객 특성을 고려하여 렌트카 이용 시 편의를 개선함으로써 광역 단위의 지역관광을 활성화하고 있다. 


\section{다. 공항 도심 접근성 및 셔틀버스 운행 서비스}

태국 사례를 보면 도심 거점형 공항보다는 지역 연계형 공항에서 LCC의 운항편 수 비중과 국제여객 수송 규모가 더 높게 나타났다. 지역 연계형 공항의 경우 활주 로 및 여객 수요를 고려하여 소형기재 중심의 수송이 이루어지면서 상대적으로 $\mathrm{LCC}$ 에 대한 의존도가 높은 것으로 분석된다. 태국 북부에 위치한 치앙마이 공항과 치앙라이 공항은 도심에서 매우 가까운 입지 조건을 갖추고 있다. 태국의 남부 해안 에 위치한 푸켓공항과 핫야이공항은 상대적으로 도심까지 거리가 멀어 공항셔틀버 스를 운행하고 있다.

\section{라. 항공사 공동 마케팅 및 모바일 안내 서비스}

태국 교통부와 공항공사는 관광산업 활성화를 위해 여행 성수기 동안 공항료 및 착륙료, 주기료를 인하하고 부정기 및 전세 항공편을 위한 공항 슬롯을 따로 확보하 는 정책을 추진 중이다. 관광수용태세 개선을 위해 중국인 전용 입국 심사대를 개설 하는 한편, VAT 현금 환급 서비스를 지방공항으로 확대 제공하고 있다. 특히, 공항 공사는 8개 언어 서비스 기반 ‘디지털 에어포츠' 앱을 개발하여 출입국 심사 대기시 간, 공항 주차장 현황에 관한 실시간 정보를 제공하고 택시 및 수화물 배달 예약 기능도 제공하고 있다. 치앙마이 공항에서는 공유차량 업체인 'Grab'과 함께 3륜 전기오토바이를 도입하여 친환경 교통서비스를 제공하고 있다. 태국관광청은 여성 관광객 유치 캠페인의 일환으로 여성 전용 입국 심사대와 특별 주차구역을 운영하 고 렌트카, 백화점, 국내선 항공권 할인 등 혜택을 제공하였다. 또한 지방의 새로운 목적지 홍보를 위해 항공업계와 공동으로 대규모 팸투어를 실시한 바 있다.

\section{마. 공항의 도시 정체성 강조 및 혁신기술 도입}

호주의 경우 시드니공항과 멜버른공항, 브리즈번공항, 퍼스공항 등 4 개의 주요 공항에 연간 항공기 운항이 집중되고 있다. 주요 공항에서 도심까지 30분 이내로 이동할 수 있으며, 공항철도와 스카이버스 외에 우버와 같은 공유차량 서비스를 쉽 게 이용할 수 있다. 호주 지방공항은 모던한 인테리어와 예술작품, 특산품 전시 등 
을 통해 지역의 고유한 정체성을 강조하고 있으며, 공항 주변에는 여행객들을 위한 호텔과 숙박시설이 위치하고 있다.

호주 정부는 주요 공항에 생체인식 시스템을 도입하여 입국심사 절차를 간소화하 고, 고소득 외국인 관광객 유치를 위한 프리미엄 제도를 마련하였다. 주정부는 외항 사와 $\mathrm{MOU}$ 를 체결하여 신규 직항노선 취항을 독려하기도 하고, 지방공항에서는 지 역관광공사와 함께 해외 마케팅을 위한 전담부서를 설립하기도 하였다. 브리즈번공 항은 혁신적인 디지털화폐 결제시스템을 도입하였으며, 멜버른공항은 LCC 전용 터 미널을 운영하고 있다.

일본·태국·호주 등 3개국 유사사례 조사 결과를 종합하여, 지방공항을 활용한 외 래관광객 유치 확대를 위한 정책적 시사점을 정리하면 다음의 표와 같다.

〈표 4-14〉 외국사례 조사를 통한 주요 시사점

\begin{tabular}{|c|c|}
\hline 핵심 이슈 & 추진 전략 및 정책 방안 \\
\hline 지방공항의 국제노선 확충 & $\begin{array}{l}\text { - 신규 취항 및 증편을 위한 공항 세일즈 정책 } \\
\text { - LCC 및 외항사 유치 강화를 위한 지원 제도 } \\
\text { - 홍콩, 대만 등 중화권과 동남아 노선 다변화 } \\
\text { - 각종 공항시설 이용료 감면, 공항 슬롯 확보 }\end{array}$ \\
\hline 지방공항의 관광수용태세 확립 & $\begin{array}{l}\text { - 국제선 체크인 카운터 통역 안내인력 배치 } \\
\text { - 중국인 관광객 전용 입국 심사대 개설 운영 } \\
\text { - 다국어 공항안내정보 모바일 앱 서비스 제공 } \\
\text { - 생체인식시스템, 디지털화폐 결제시스템 도입 }\end{array}$ \\
\hline 지방공항 연계교통 서비스 개선 & $\begin{array}{l}\text { - 리무진 택시, 렌트카 할인 및 이용편의 개선 } \\
\text { - 도심 접근성 부족한 경우 공항셔틀버스 운행 } \\
\text { - 공항철도, 공항버스 외 공유차량 서비스 편리 }\end{array}$ \\
\hline 지방공항 외래관광객 유치 마케팅 & $\begin{array}{l}\text { - 해외 인바운드 시장 유치를 위한 공동 마케팅 } \\
\text { - 인근 지자체, 항공사 연계 초청 팸투어 실시 } \\
\text { - 관광공사와 항공사 공동 대규모 팸투어 개최 } \\
\text { - 도시의 정체성과 예술성을 강조한 공항 시설 }\end{array}$ \\
\hline
\end{tabular}



지방공항을 활용한 지역관광 활성화 방안

제5장 향후 정책 추진방안 



\section{제1절 목표 및 기본방향}

국제관광에 있어 항공교통의 중요성이 점점 커짐에 따라 국내 지방공항의 입국 관문 역할을 강화하고 지역관광을 활성화시킬 필요가 있다. 기존의 지방공항 국제 노선은 우리 국민의 해외여행 수요와 선호 목적지를 중심으로 직항 노선과 운항 편 수가 배분되어 온 경향이 많았다. 그러나 향후에는 아웃바운드 수요 중심에서 인바 운드 수요와 균형을 추구하는 접근 전략이 필요하다. 또한 국내 지방공항 활성화를 위해서는 대형항공사보다는 저비용항공사와 외항사를 적극적으로 유치할 필요가 있다.

조사 분석결과를 고려할 때, 지방공항을 이용하는 FIT 여행객 관점에서 사전 항 공권 구매, 출국 및 항공편 이동, 지방공항 도착 및 입국, 현지 안내정보 수집, 대중 교통을 이용한 주변 관광지 이동, 지방공항을 통한 출국 등 주요 단계를 점검할 필 요가 있다. 연구의 주요 대상인 김해공항은 '대도시형 지방공항' 의 관점에서, 무안 공항은 '지역연계형 지방공항'의 관점에서 외래관광객 유치 확대를 위한 방안을 제 시하고자 한다.

지방공항은 단순히 국가 간의 이동을 위한 항공교통 시설일 뿐만 아니라, 방한관 광 여행의 첫 시작점이자 그 지역(도시)을 상징하는 매력장소로서 거듭날 필요가 있 으며, 정부가 추진 중인 관광거점도시 조성 사업 등과 연계하여 시너지 효과를 도모 할 필요가 있다. 또한 문화체육관광부 및 국토교통부의 주요 계획을 고려하여 관광 과 항공 분야 간 협력 방안을 모색하고, 각 지방공항별로 지자체, 관광공사, 공항공 사, 항공사, 여행사 등을 포함하는 협력체계 운영을 통해 관련 주체별 역할과 협력 방안을 제시하고자 한다.

향후 정책의 목표는 국내 지방공항을 활용하여 방한 외국인 관광객의 지방방문을 촉진하고 지역관광을 활성화하는데 있다. 이러한 정책 목표를 실현하기 위한 핵심 
부문은 방한 외국인 관광객들의 이동 흐름을 고려하여 I. 지방공항 여객 수요 창 출, II. 지방공항 이용 편의 개선, III. 지역 연계 및 관광 활성화 등으로 크게 구분할 수 있다.

첫째, 지방공항을 통해 한국을 방문하는 외국인 관광객 수요 창출을 위해서는 (1) 국제노선 공동 개발, (2) LCC 및 외항사 유치, (3) 환승관광객 수요 확대 등의 정책 추진이 필요하다.

둘째, 방한 외국인 관광객 관점에서 지방공항 이용시 편의성 제고를 위해서는 (4) 외국어 안내 정보 서비스, (5) 공항 연계 교통 시스템, (6) 면세 및 쇼핑 만족 제고 등의 개선 과제가 요청된다.

셋째, 지방공항의 배후 도심 및 주요 관광지와 연계를 강화하고 외국인 관광객 유치를 통해 지역관광을 활성화하기 위해서는 (7) 국제적인 관광매력 발굴, (8) 지방 공항의 지역 명소화, (9) 해외 현지 마케팅 강화 등의 정책 추진이 필요하다.

[그림 5-1] 핵심 부문별 추진과제

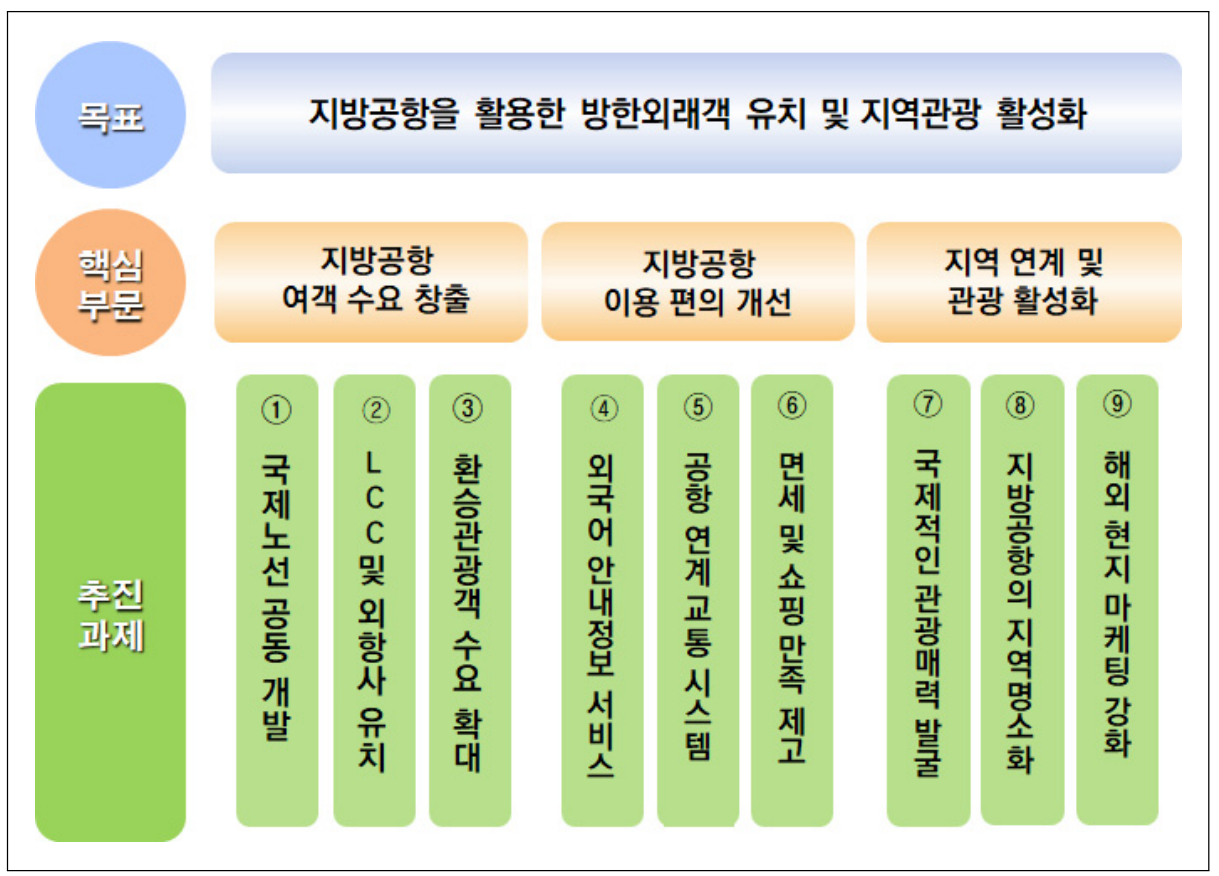




\section{제2절 각 부문별 추진과제}

\section{1. 지방공항 여객 수요 창출}

\section{가. 국제노선 공동 개발}

1) 배경 및 필요성

국내 지방공항 국제노선은 우리 국민의 해외여행 수요와 선호 목적지를 중심으로 직항노선과 운항편수가 배분되어 온 경향이 많았다. 그러나 향후 아웃바운드 항공 시장의 성장이 둔화될 것으로 예측됨에 따라, 기존 아웃바운드 수요 중심에서 인바 운드 수요와 균형을 추구하는 접근 방식이 요청된다.

항공시장은 아웃바운드 시장과 인바운드 시장으로 구분된다. 항공사는 두시장의 마켓조사를 통한 항공기 취항계획을 수립하는데, 실제로는 수요와 항공기 기단 특 성에 맞춰 어떤 시장에 중점을 둘지를 결정하게 된다. 특정 휴양지나 관광도시를 운항할 경우, 일반적으로 아웃바운드 시장에 보다 더 초점이 맞춰져 있다.

과거 우리나라 양대 대형항공사(Full Service Carrier, FSC)는 인바운드 시장 보 다는 상대적으로 수요 확보에 용이한 아웃바운드 시장에 초점을 두고 사업을 영위 하였다. 특히 1989년 해외여행자유화 이후 급격한 경제성장과 발전에 힘입어 우리 국민의 해외여행 수요가 증가했기 때문에 항공사의 공급 또한 아웃바운드 수요에 초점이 맞춰져 있었다.

이와 같은 맥락에서 2005년 이후 새롭게 시장에 진입한 국내 저비용항공사(Low Cost Carrier, LCC)도 처음 국제선 취항을 시작할 때 아웃바운드 시장에 중점을 둔 것은 사실이다. 이러한 항공사의 운영 전략은 우리 국민의 해외여행에 대한 니즈 에 부응하고자 하는 항공사의 전략이기도 했다. 하지만 항공수요에 큰 영향을 미치 는 요인인 경제성장률과 인구추세를 보면 이러한 항공시장의 성장이 언제까지 지속 
될 수 있을지는 매우 불명확하다.

즉, 인바운드 시장의 성장 없이 아웃바운드 시장만으로는 우리나라 항공시장의 성장은 매우 제한적일 수 있다. 따라서 아웃바운드 수요에 지나치게 치우친 전략을 구사하기 보다는 장기적으로 인바운드 수요와 아웃바운드 수요의 균형을 추구하는 전략을 수립할 필요가 있다. 그 구체적인 전략 방안의 하나로 항공과 관광분야가 협력하여 정책을 마련하고 상호 윈-윈 할 수 있는 국제노선을 공동으로 개발할 필 요가 있다.

\section{2) 추진방안}

국토교통부와 항공사들이 중심이 되는 국제노선 개발 과정에 문화체육관광부, 관 광공사, 여행업계 등 관광분야 전문가들의 참여가 이루어질 필요가 있다. 지방공항 의 국제노선을 개발함에 있어서 인바운드 관광정책 측면에서 유치 확대가 필요한 전략시장 국가들을 우선적으로 고려하고, 취항도시의 경우 지방의 소규모 휴양도시 보다는 관광송출 잠재력이 높은 대도시를 선정할 필요가 있다.

2020년 8월 기준 우리나라는 항공자유화협정이 체결된 국가를 포함하여 약 89 개국과 항공협정이 체결되어 있다. 우리나라는 이미 2006년 중국의 산동성, 하이난 성과 항공자유화협정을 체결하였지만, 이 두 성을 제외한 곳은 아직도 운수권의 제 한이 걸려 있다. 중국과의 항공협상을 통해 추가적으로 확보한 운수권은 항공사에 배분되는데, 지방공항에 신규노선이 취항될 수 있도록 운수권 배분에 우선권을 주 는 정책을 추진할 필요가 있다.

중국은 우리나라의 제 1 인바운드 관광시장으로서 중국과 항공자유화가 확대된다 면 그 잠재력은 매우 크다고 볼 수 있다. 중국은 23 개의 성에 1,000 만 명이 넘는 광역권 도시가 많이 존재하고 있으며, 향후 중국의 경제성장과 해외여행 수요 증가 에 부응하여 이러한 메가-도시들과의 연계를 통해 국내 지방공항의 신규노선을 확 보할 필요가 있다.

최근 중국은 베이징 수도공항의 포화에 따라, 2019년 9월 공항수용량 확대를 위 해 북경의 다싱 제 2 신공항을 북경 남쪽에 위치한 다싱구에 개항하였다. 이와 같은 중국의 새로운 공항개항에 따라 공항시설의 여유와 슬롯 확보가 유리하기 때문에 
북경 다싱 신공항을 중심으로 하는 국내 지방공항과의 노선 확대도 적극 검토해 볼 필요가 있다.

〈표 5-1〉 우리나라 항공자유화 협정 체결 현황

(2019년 6월 기준)

\begin{tabular}{c|c}
\hline 지역 & 대상국가 (30개국) \\
\hline 동북아 & 중국(산동성, 해남성), 일본(하네다 공항 제외), 홍콩, 대만, 마카오 \\
\hline 동남아 & 태국, 베트남, 말레이시아, 미얀마, 캄보디아, 라오스 \\
\hline 서남아 & 몰디브, 스리랑카 \\
\hline 러시아/CIS & 우크라이나, 아제르바이잔, 벨라루스 \\
\hline 유럽 & 오스트리아, 스페인 \\
\hline 미주 & 미국, 캐나다, 멕시코, 브라질, 파나마, 칠레, 페루, 에콰도르, 파라과이 \\
\hline 기타 & 호주(시드니 등 제외), 케냐, 튀니지 \\
\hline
\end{tabular}

자료: 국토교통부

일본의 경우 2007 년 동경 하네다 공항을 제외한 모든 지역과 항공자유화협정이 체결되어 있어 운수권의 제한이 없다고 볼 수 있다. 이처럼 일본과 항공자유화협정 을 맺음으로 인하여 우리나라 항공사가 일본의 지방공항에 다양한 노선을 취항하였 고 양국 간의 수송실적 향상에도 많은 기여를 하였다. 향후에도 국내 지방공항과의 연결을 통해 항공사의 공급량을 늘리고 서비스를 개선하여 방한 일본인 관광시장 유치를 강화할 필요가 있다.

최근 정부의 방한시장 다변화 정책 추진에 따라 중국과 일본 뿐 아니라 동남아 시장의 유치 중요성이 강조되고 있는 만큼, 향후 지방공항의 국제노선 개발 시 동남 아시아의 주요 국가들을 우선적으로 검토할 필요가 있다. Top10 시장에 속하는 홍 콩, 베트남, 태국의 경우 매년 많은 관광객들이 우리나라를 방문하고 있지만 입국 경로가 인천공항에 집중된 경향이 높아 지방공항의 적극적인 유치 노력이 요청된 다. 일본 간사이공항의 경우, 중국과 한국노선 외에 홍콩과 대만노선이 활발히 운항 되고 있다는 점을 참고할 필요가 있다.

항공업계 입장에서도 국내 지방공항의 국제노선 다변화 전략이 필요할 것으로 판 단된다. 2017년 이후 중국과의 사드 분쟁으로 인해 국내 항공사들도 자구책으로 항공기자재의 활용을 다른 지역으로 확대/전환해야 했다. 일본시장도 한.일 양국 간의 정치적 이슈가 매우 민감한 변수로 작용하면서 항공시장에 적지 않은 영향을 
끼쳐왔다. 우리나라 항공시장은 이러한 외생 변수들을 극복하는 과정에서 베트남, 대만, 인도네시아, 필리핀 등 동남아시아로 시장 다변화를 꾀하게 되었다. 이는 항 공업에 새로운 전환점이었으며 향후에도 중국과 일본노선에 대한 의존도를 보다 완 화시킬 필요가 있다.

2019년 현재 우리나라는 싱가포르를 포함한 대부분의 아세안 국가들과 항공자유 화협정을 체결하여 앞으로 국적항공사들의 아세안 노선 운영이 확대될 것으로 예상 된다. 이러한 기회를 활용하여 아세안의 주요 도시와 국내 지방공항을 연결하는 노 선을 개설할 필요가 있다. 노선 다변화는 항공사의 기재 도입과 운영, 그리고 항공 기 스케줄과 긴밀하게 연계되어 있기 때문에 항공사의 운영을 면밀히 검토하고 이 를 적용해야 한다. 우리나라의 저비용항공사의 기단은 200석 내외의 항공기로 항속 거리가 $5,000 \mathrm{~km}$ 내외의 단거리 운항만 가능한 상황이다. 하지만 앞으로 국적 저비 용항공사는 효율적인 차세대 항공기 기재를 도입하여 단거리 노선에서부터 중거리 노선까지 확대하는 전략을 마련할 필요가 있다.

\section{나. LCC 및 외항사 유치}

\section{1) 배경 및 필요성}

저비용항공사 시장의 관점에서 보면, 아시아태평양 지역의 LCC 공급좌석 수는 과거 10 년 동안 약 4 배 증가를 보였다. 이러한 저비용항공사의 활성화는 공급좌석 수의 증대뿐만 아니라 소비자들에게 다양한 노선선택권, 저렴한 항공요금, 다양한 기내서비스를 제공하였다. 아시아태평양 지역의 LCC 시장은 앞으로도 지속적으로 성장할 것으로 예측되고 있다. 
[그림 5-2] 아시아태평양 지역의 연간 LCC 공급좌석 수 변화

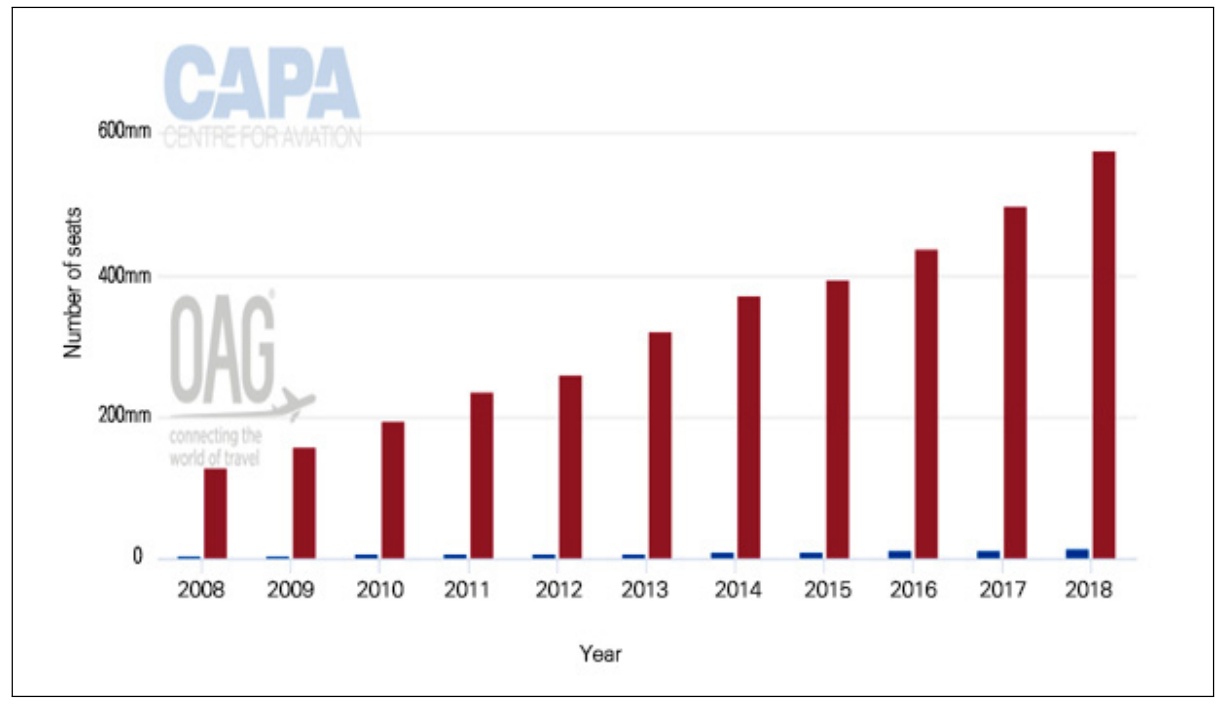

자료: CAPA - Centre for Aviation \& OAG

미국과 유럽에서 시작된 저비용항공사 사업모델이 아시아지역으로 확장되면서 국내에도 저가항공사가 도입되었다. 2009년 국내 항공시장에 저비용항공사가 본격 적으로 진출하면서, 최근 10 년 동안 저비용항공사의 시장점유율은 지속적인 성장을 보였으며, 2019년에는 29.5\%의 점유율을 기록하였다.

최근 5년간 우리나라 국적 항공사의 매출액은 총 22조원 규모로 추산되며, 전체 매출액 중에서 대형항공사(FSC)와 저비용항공사(LCC)는 각각 $80.1 \%, 19.9 \%$ 를 차 지하고 있다. 2019 년 기준으로 대형항공사의 매출액은 18 조 2,162 억 원으로 최근 5 년간 평균 $2 \%$ 증가에 머물렀으나, 저비용항공사의 매출액은 4 조 5,154 억 원으로 연평균 $25 \%$ 의 빠른 성장을 보인 것으로 나타났다.

방한 관광시장 확대 측면에서는 저비용항공사(LCC)와 외국국적 항공사를 적극 유치하는 것이 효과적이라 할 수 있다. 특히 국내 지방공항의 경우 공항 운영 활성 화를 위해 저비용항공사(LCC)에 대한 의존도가 높은 상황이다. 김해공항의 경우, 2019년 국제노선 전체 운항편수 가운데 LCC가 차지하는 비율이 $49.4 \%$ 로 나타났 으며, 외항사 비율은 $31.2 \%$ 로 조사되었다. 무안공항의 경우, 같은 해 국제노선 전 체 운항편수 가운데 LCC가 차지하는 비율이 76.9\%로 압도적으로 높게 나타났으 며, 외항사 비율은 $23.0 \%$ 로 조사되었다. 


\section{2) 추진방안}

저비용항공사(LCC)를 국내 지방공항에 유치하기 위해서는 항공운수권16)과 공항 슬롯17)의 문제 해결이 선행되어야 한다. 아직까지 중국 내 많은 지역이 자유화가 되어 있지 않기 때문에 운수권을 우선 확보해야 우리나라와 노선을 개설할 수 있으 며 지방공항으로의 취항도 가능하다. 항공협상으로 확보한 운수권은 항공사에게 배 분되는데 지방공항에 신규노선이 취항될 수 있도록 운수권 배분에 우선권을 주는 정책을 검토할 필요가 있다.

더 나아가 항공자유화18)의 확대를 통해 저비용항공사가 취항할 수 있는 신규노 선의 확보가 반드시 필요하다. 정부는 항공자유화를 통해서 운수권 제한을 철폐하 고 항공사들의 자율 경쟁을 통해 공급량을 결정하고 노선을 선택하며 항공요금을 자율적으로 정하게 되어, 결과적으로는 항공소비자에게 편익이 돌아갈 수 있는 정 책을 추진해 나가야 할 것이다. 이를 통해 국적 저비용항공사나 외국항공사들의 취 항의 폭을 확대할 수 있다.

한편 운수권이 확보되어도 상대 취항공항의 슬롯이 확보되어야 최종적으로 항공 기의 취항이 가능하다. 이러한 지방공항발 운수권 배분에 따라 국내 지방공항의 인 바운드 시장이 확대될 것이며 저비용항공사의 국제항공 네트워크도 강화될 수 있다.

현재 김해공항의 슬롯은 거의 한계에 와있다. 김해공항은 군 공항으로 슬롯 확대 가 매우 제한적이긴 하나 공군과의 지속적인 협의를 통해 신공항 개항 전까지 최대 한 슬롯을 확보할 필요가 있다. 그러나 향후 영남권 신공항 개발에 따라 공항용량이 확대된다면 슬롯 부족문제는 자연스럽게 해결될 것으로 예상된다.

우리나라의 김포공항, 김해공항, 대구공항, 광주공항은 운항제한시간 19$)$ 이 존재하 고 있다. 김해공항의 경우 7시간(23 06시) 동안 운항을 할 수 없는 규정이 있어서

16) 운수권(Traffic Right)이란 여객/화물노선의 운항지점, 운항기종, 운항횟수 등의 권리를 의미하며 통상 국가 간 항공회담을 통해 확보되며 이후 항공사에게 배분이 된다. 운수권은 「국제항공운수권 및 영공통과 이용에 관한 규칙(국토부령)」에서 정한 기준에 따라 분야별 민간 전문가로 구성된 「항공교통심의위원회」 에서 심의된다.

17) 슬롯(Slot)은 항공사가 특정 공항에 특정한 날짜, 특정한 시각에 운항(계획된 출발/도착)할 수 있도록 배정 된 시간을 의미한다.

18) 항공자유화(Open Sky)란 국가간 항공노선에 대한 진입을 개방하는 것으로 항공사 수 및 운항편수가 무제 한 허용되는 것으로 국가간 항공운송의 각종 규제를 없애는 정책이다.

19) 운항제한시간(커퓨타임, Curfew Time)이란 항공기 소음 등 공항의 특수사항으로 인하여 야간에 비행기 이착륙을 금지하는 시간을 의미한다. 
이를 완화하기 위한 추가적인 협의도 필요하다. 하지만 추가 운항이 가능한 경우에 도 이로 인한 소음 문제 제기가 예상되므로 이에 대한 대책도 함께 마련되어야 한 다. 현재 무안공항은 슬롯이나 커퓨타임에 제한이 없기 때문에 항공기 취항에는 큰 제약이 없는 상황이다.

특정 공항의 활성화를 위해서는 그 공항에서 기반을 두고 운항하는 항공사가 필 수적이다. 그 이유는 해당 허브항공사가 허브공항에 노선을 유치할 경향이 크기 때 문이다. 대구공항의 경우 티웨이항공이 허브항공사로, 김해공항의 경우 에어부산 등이 허브항공사로 운항 중이다. 따라서 무안공항 역시 허브항공사 유치가 필요하 며 특히 국적 저비용항공사나 해외 저비용항공사를 유치하는 전략이 매우 중요할 것으로 판단되다.

아울러 저비용항공사들 간 전략적 제휴를 통해 항공사의 네트워크를 확장할 필요 가 있다. 예컨대, 이스타항공이 $\mathrm{HK}$ express 항공 등과 같이 유플라이(U-Fly)라는 전략적 제휴를 맺는가 하면, 중국 최대 LCC인 춘추항공 및 국내 LCC인 티웨이항 공이 함께 코드쉐어를 체결하여 네트워크를 확장하고 있다. 제주항공도 밸류얼라이 언스(Value alliance)에 가입하여 동맹을 강화하고 있다. 향후에도 이러한 전략적 제휴를 통해 항공사의 네트워크를 확장하고 LCC의 지방공항 취항을 유도함으로써 인바운드 수요를 창출해야 할 것이다.

지방공항에 저비용항공사를 유치하기 위해서는 공항과 항공사, 지자체, 관광공사 간의 협력과 공동 마케팅이 중요하다. 항공사는 불확실한 신규노선 개발에 있어 매 우 조심스럽기 때문에 이에 대한 공항과 지자체의 적극적인 지원이 필요하다. 즉, 공항의 적극적인 사용료 할인과 지자체의 재정적인 지원이 필수적이라 할 수 있다. 관광공사도 신규노선 개발을 위해 적극적으로 참여하고 저비용항공사와의 해외 마 케팅 협력을 추진해야 할 것이다.

참고로 일본의 지방소도시들의 경우 우리나라 LCC 노선을 유치하기 위해 적극적 인 지원 제도를 다양하게 운영하고 있다. 공항시설 사용료, 착륙료 등 공항에 대한 전반적인 비용을 감면해주고, 추가적으로 공항 조업비를 비롯하여 현지 마케팅과 한국 내 마케팅 비용 등에 대해서도 적극적인 지원을 제공하고 있다. 일본의 지방소 도시들은 지자체와 공항공사, 여행사, 호텔, 관광지업체 등 관광과 밀접한 연관이 있는 주체들이 함께 항공사를 방문해 미팅을 진행하고, 항공사에서 그 지역을 운항 
할 시 한국인들의 여행에 대한 불편함과 비용적 부담을 절감시킬 수 있도록 다양한 지원금과 할인 혜택 등을 제공하고 있다.

〈표 5-2〉지방공항 활성화 사업 재정 지원 현황

\begin{tabular}{|c|c|c|c|}
\hline 구분 & 대상공항/노선/항공사 & 감면내용 & 지원조건 \\
\hline \multirow{3}{*}{$\begin{array}{l}\text { 국제선 } \\
\text { 신규 취항 }\end{array}$} & $\begin{array}{l}\text { 핵심공항 } \\
\text { (김해·제주) }\end{array}$ & $\begin{array}{l}\text { 3년간 착륙료·정류료· } \\
\text { 조명료 감면 } \\
\text { (1년차: } 100 \%, 2 \text { 년차: } \\
\text { 50\%, 3년차: } 30 \% \text { ) }\end{array}$ & $\begin{array}{l}\text { (1) 과거 } 1 \text { 년 이내에 운항한 실적이 없고, } \\
\text { (2) 취항 개시 후 } 3 \text { 개월( } 13 \text { 주) 이상 운항하되, } \\
\text { 주 } 2 \text { 편 이상 운항한 경우 } \\
※ \text { 최소 } 3 \text { 개월 최대 } 3 \text { 년간 또는 } 5 \text { 년간 } \\
\text { (5,000km 이상 노선의 경우) 지급 }\end{array}$ \\
\hline & $\begin{array}{l}\text { 중점육성공항 } \\
\text { (대구·무안·청주·양양) }\end{array}$ & $\begin{array}{l}\text { 3년간 착륙료·정류료· } \\
\text { 조명료 감면 } \\
\text { (1 3년차: 100\%) }\end{array}$ & $\begin{array}{l}\text { (1) 과거 1년 이내에 운항한 실적이 없고, } \\
\text { (2) 취항 개시 후 3개월(13주) 이상 운항하되, } \\
\text { 주 } 2 \text { 편 이상 운항한 경우 } \\
\text { ※ 최소 } 3 \text { 개월 최대 3년간 지급 }\end{array}$ \\
\hline & $\begin{array}{l}\text { 국제선 부정기 유치 } \\
\text { (울산·여수·포항·사천· } \\
\text { 원주) }\end{array}$ & $\begin{array}{l}\text { 3년간 착륙료·정류료· } \\
\text { 조명료 감면 } \\
\text { (1 3년차: 100\%) }\end{array}$ & $\begin{array}{l}\text { (1) 과거 1년 이내에 운항한 실적이 없는 경우 } \\
\text { (2) 취항 개시 후 } 3 \text { 개월(13주) 이상 연속하여 } \\
\text { 운항하되, 주 } 2 \text { 편 이상 운항한 경우 }\end{array}$ \\
\hline
\end{tabular}

자료: 한국공항공사 내부자료 일부 발췌 정리.

\section{다. 환승관광객 수요 확대}

\section{1) 배경 및 필요성}

환승관광객의 유치는 공항시설사용료(착륙료, 정류료, 조명료) 등의 항공수익 뿐 만 아니라 공항 내 면세점 소비 확대, 공항 주변지역과 배후지역에서 환승관광객의 소비로 인한 비항공수익까지 증대시킬 수 있다. 그러나 현재 우리나라의 환승(통과) 여객 거의 대다수가 인천공항에 집중되고 있으며, 그 외 지방공항의 환승여객 시장 수요나 유치 실적은 매우 미미한 상황이라 할 수 있다.

지방공항은 인천공항에 비해 환승여객 수요가 많지 않고, 배후도시 및 주변지역 의 환승투어 프로그램에 대한 사전 홍보와 예약 체계가 미흡하여 실질적인 사업성 과가 부족한 실정이다. 실제로 항공여객OD 조사 데이터의 분석 결과에 따르면, 대 부분의 응답자들이 온라인 사이트를 통해 항공권을 구매한 것으로 나타남에 따라, 해외 현지의 사전 여행 준비단계에서 국내 지방공항의 환승투어 프로그램에 관한 온라인 홍보를 추진할 필요가 있다.

또한, 항공여객OD 조사 데이터 분석 결과에 따르면, 김해공항이나 무안공항을 
환승공항으로 선택한 이유는 항공요금이 저렴하고 항공스케줄이 적합했기 때문인 것으로 나타났다. 향후 국내 지방공항의 환승노선 개발 시 이러한 점을 고려할 필요 가 있다. 한편, 국내 지방공항을 이용하는 중국인 및 동남아 환승관광객 대상 비자 완화 정책은 신규 방한시장 수요 창출을 통해 지방공항 활성화에 기여할 수 있을 것으로 예상된다.

\section{2) 추진방안}

환승여객은 크게 동일한 항공사 간의 환승여객(intraline)과 다른 두 항공사 간의 환승여객(interline), 그리고 5자유 운수권을 활용한 환승여객(direct transit)으로 구분할 수 있다.

동일한 항공사 간의 환승은 경유국의 항공사가 경유공항에서 허브역할을 하며 다 양한 네트워크를 가지고 승객을 최초 출발지에서 경유국을 거쳐 최종 목적지까지 운송하는 것을 의미한다. 예를 들면, 인천공항에서 대한항공이 터미널 2를 이용하 여 유럽과 미주에서 오는 여객을 일본과 중국, 동남아시아로 운송하는 것을 의미한 다. 주로 국적항공사가 3 과 4 항공자유를 이용하여 운송한다.

다른 두 항공사 간의 환승은 네트워크 운영 측면에서는 유사하지만 중간 경유지 를 기준으로 다른 두 항공사가 운항하여 연결하는 것을 의미한다. 주로 6 항공자유 를 이용하여 승객을 운송하며, 이를 위해서는 다른 두 항공사 간에 상무협정이 체결 되어야 한다.

또한 5자유 운수권을 이용한 환승여객은 동남아 또는 중국, 일본 항공사가 우리 나라의 한 지점(예: 김해공항)을 거쳐 미주나 유럽 또는 호주를 최종 목적지로 하는 노선에서 운송하는 것을 의미한다. 이를 위해서는 취항항공사가 5자유 운수권을 확 보해야 한다.

기존의 지방공항 환승여객은 제주공항 위주로 이뤼지고 있다. 특히 제주공항은 중국과 대만항공사들의 환승노선으로 운영되고 있다. 그러나 현재 김해공항의 경우 환승률(환승객수)이 높은 환승허브공항으로 육성하기 위해서는 많은 제약이 따를 것으로 판단된다.

항공운송산업은 네트워크 산업이며 규모의 경제를 따르기 때문에 충분하고 다양 한 항공노선이 선결되어야 환승에 유리하다고 할 수 있다. 또한 환승공항으로서 주 
변지역의 관광인프라도 함께 개발될 필요가 있다. 특히 대만과 중국으로 연결하는 환승노선을 추가적으로 개발하여 김해공항에서 환승을 유도하고, 부산시와 주변 배 후지역으로 환승관광객을 유치하는 전략을 수립해야 할 것이다. 보다 좋은 방안은 허브항공사인 국적 LCC가 대만노선의 취항 확대를 통해 대만 항공사와 전략적 제 휴를 추진하는 것이다.

무안공항의 경우에는 국제선 네트워크의 규모를 볼 때 환승관광객 유치에 있어서 는 매우 제한적일 수 있다. 하지만 무안공항을 통한 중국인 관광객의 제주도 및 국 외 환승 수요에도 관심을 기울일 필요가 있다. 또한 동남아 국가를 최종 목적지로 하는 일본 승객을 국내에서 환승하여 운송하는 전략도 강화할 필요가 있다.

지방공항의 환승관광 수요 확대를 위해서는 공항 내 환승 편의시설 확충 및 당일 환승관광 프로그램 개발이 우선적으로 추진되어야 할 것이다. 최근의 개별여행 증 가 추세를 고려하여 해외 현지에서 항공권을 예약 구매하는 단계에서부터 국내 지 방공항의 환승관광 프로그램을 인지할 수 있도록 사전 홍보를 강화하고 온라인 예 약 시스템을 구축할 필요가 있다. 당일 환승관광 프로그램의 경우 1 시간 코스부터 5시간 코스까지 시간대와 테마를 다양하게 하여 환승객들의 스케줄에 맞는 프로그 램을 선택할 수 있도록 해야 한다.

\section{2. 지방공항 이용 편의 개선}

\section{가. 외국어 안내 정보 서비스}

1) 배경 및 필요성

과거부터 지금까지 우리나라를 찾는 외국인 관광객들이 국내여행 중에 가장 불편 을 느끼는 사항은 바로 언어소통 문제이다. 매년 실시되고 있는 외래관광객 조사에 따르면, 한국 여행 경험에 대한 세부 항목별 만족도에서 치안, 쇼핑, 대중교통, 출입 국절차 등은 만족도가 높게 나타나지만, 언어소통의 경우 여전히 장애요소로 뚜렷 한 개선이 이뤄지지 않고 있다. 또한 동 조사결과에 따르면, 외래관광객들이 한국 여행을 준비하면서 가장 필요했던 정보는 '이동거리 및 교통편', ‘방문지 정보', ‘음 식 및 맛집 정보' 등인 것으로 나타났다. 
외국인 관광객들이 국내 지방공항을 통해 입국한 후 인근 도시나 주변지역을 방 문하여 여행할 경우 이러한 언어소통과 정보부족 문제는 더 큰 불편요인이 될 수 있다. 본 연구에서 실시한 외국인 개별 심층면접조사 결과에 따르면 김해공항이나 무안공항을 이용해 본 외국인들이 버스, 택시 등 대중교통을 이용하거나, 주변 관광 지의 운영시간 등 구체적인 정보를 구할 때, 현지 식당에서 음식 메뉴를 고를 때 외국어 안내 정보가 부족하여 불편했다는 의견이 많았다. 따라서 향후 국내 지방공 항을 활용하여 방한 외래관광객 유치를 강화하기 위해서는 전반적인 외국어 안내 정보 서비스를 점검하고 체계적으로 개선할 필요가 있다.

〈표 5-3〉 한국 여행 준비 중 가장 필요했던 정보

(중복응답, 단위: \%)

\begin{tabular}{c|c|c}
\hline 구분 & 2018년 & 2019년 \\
\hline 이동거리 및 교통편 & 52.4 & 51.0 \\
\hline 방문지 정보 & 47.3 & 47.1 \\
\hline 음식 및 맛집 정보 & 46.8 & 46.2 \\
\hline 숙박 시설 & 35.4 & 35.3 \\
\hline 쇼핑 장소 & 33.9 & 34.9 \\
\hline 지역축제 및 행사 정보 & 9.6 & 10.1 \\
\hline
\end{tabular}

자료: 2018, 2019 외래관광객 조사

\section{2) 추진방안}

우선 국내 지방공항에서 중국, 일본, 대만, 홍콩, 베트남 등 주요 방한 관광시장별 로 특별 입국 환대기간을 지정하여 특정기간 동안 공항 내 전용 출·입국 심사대를 운영하면서 이용 항공사 체크인 카운터 등에 해당 언어권 통역안내 인력을 배치하 는 방안을 검토해 볼 수 있다. 태국의 경우, 주요 공항에 중국인 전용 입국 심사대를 마련하고 중국어가 가능한 출입국 심사관을 배치하여 중국인 관광객들을 위한 편의 서비스를 제공한 바 있다.

향후 방한 개별여행(FIT) 시장 유치에 보다 초점을 두고, 외국인 관광객들이 국내 지방공항에 도착하여 지역여행을 하는데 필요한 안내정보를 손쉽게 수집할 수 있도 록 공항 내 인프라와 서비스를 개선할 필요가 있다. 최근 주요 공항에 설치된 안내 키오스크의 경우 해당 지역의 관광공사/재단과 협력하여 공항 주변의 대표 관광지 
에 대한 콘텐츠와 외국어(영어) 정보 등을 보완할 필요가 있다. 특히, 외국인 개별여 행객들이 필요로 하는 대중교통, 주변 관광지, 맛집, 숙박시설, 쇼핑 등에 관한 상세 한 안내정보 서비스를 제공할 필요가 있다. 또한 국제선 터미널 내부 바닥과 출입구 앞 기둥면을 활용하여 배후 도심이나 주변 관광지로 이동하기 위한 연계교통수단에 관한 외국어 안내정보를 효과적으로 전달할 필요가 있다.

한편 2020년부터 시행되고 있는 「제3차 항공정책기본계획」에서는 국내 지방공 항의 운영 전략과 추진 과제에 관한 내용을 포함하고 있다. 향후 정부는 인공지능, 로봇, 첨단 미디어, 생체정보 인식 등 주요 기술과 서비스를 활용한 신개념 여객 서 비스 제공이 가능한 스마트 공항을 추진할 계획이다. 특히 생체정보 인식 시스템 도입은 탑승수속 절차는 간소화하고 항공보안은 강화하여 인바운드 수요 창출에 기 여할 것으로 예상하고 있다.

이러한 스마트 기술은 지방공항을 이용하는 외국인 개별여행객들을 위한 안내 정 보 서비스 향상에 우선적으로 적용될 필요가 있다. 일례로, 태국공항공사에서 현재 운영 중인 모바일 앱 서비스를 참고하여 국내 지방공항에서도 영어, 중국어, 일어, 스페인어, 러시아어 등 다양한 외국어 안내 정보 서비스를 제공할 필요가 있다. 항 공편 운항 정보 뿐 아니라 보안 및 출입국 심사 대기시간, 공항 택시 및 리무진 예 약, 수하물 배달 및 보관 등에 관한 실시간 정보 서비스를 제공함으로써 언어소통 문제로 인한 불편함을 크게 감소시킬 수 있다.

[그림 5-3] 태국 지방공항의 중국인 전용 입국심사대

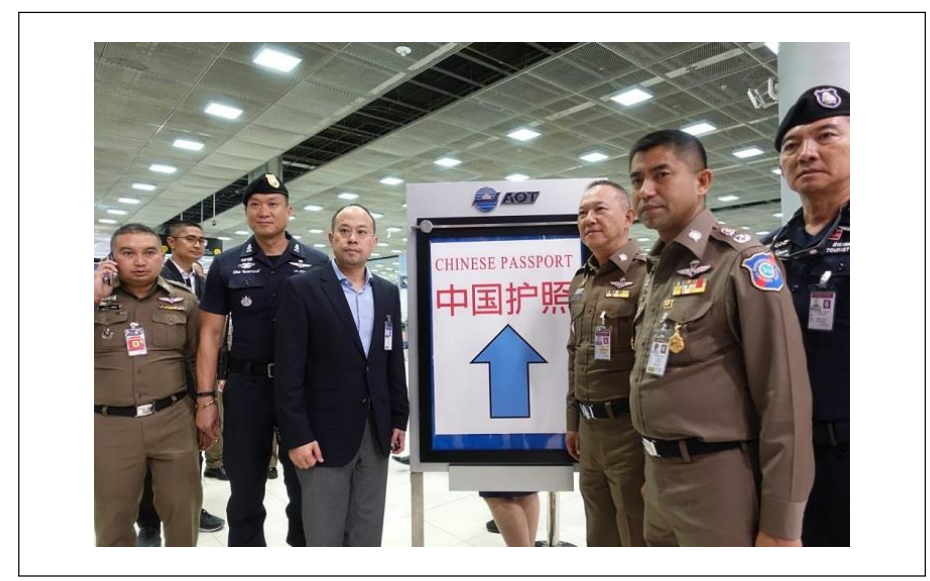

출처: Thailand Tourist Police 


\section{나. 공항 연계 교통 시스템}

1) 배경 및 필요성

국내 지방공항을 활용하여 방한 외국인 관광객들을 유치하기 위해서는 공항의 접 근성 및 공항에서 배후 도심과 주요 관광지까지 연결하는 대중교통 수단에 대한 고 려가 반드시 필요하다. 우리나라의 8개 국제공항 가운데 인천공항, 김포공항, 제주 공항 등 일부 공항을 제외하면 공항의 접근성 및 공항 인근지역과의 연계교통 서비 스가 매우 부족한 실정이다.

현재 인천공항을 비롯한 국내 공항은 고속철도(KTX) 노선과 직접 연결되어 있지 못하며, 김해공항의 경우 부산-김해 경전철이 운행되고 있다. 특히, 무안공항은 공항 의 지리적 입지 상 접근성도 매우 열악하여 배후도시인 광주나 전남지역에서 공항까 지 이동하는데 평균 한 시간 반가량 소요되는 것으로 조사되었다. 또한 김해공항이 나 무안공항을 통해 출·입국하는 외국인 대다수가 개별여행객이나 대중교통 연계수 단이 불편하고 렌트카나 공유차량 서비스가 부족하다보니 택시를 이용하는 경향이 높게 나타나고 있다. 향후 개별여행(FIT) 중심의 방한 관광시장 증가가 예상됨에 따 라 이들 수요자 관점에서 지방공항과 연계 교통서비스를 개선해나가야 할 것이다. 과거부터 지금까지 지방공항의 접근성을 개선하기 위한 노력은 지속되어 왔으나, 대중교통 수단의 운영적/재무적 측면에서 현실적인 문제에 부딪히면서 개선이 쉽지 않은 것이 사실이다. 공항 접근성 개선 및 연계 교통서비스의 확충은 관광부문 단독 의 노력만으로는 곤란하며 국토교통부 등 관계부처 및 해당 지자체와의 역할 분담 과 협력이 필수적으로 요청된다.

\section{2) 추진방안}

대도시형 지방공항에 해당하는 김해공항의 경우, 도심공항 터미널을 운영함으로 써 관광객들의 접근성과 편의성을 향상시키는 방안을 검토해볼 수 있다. 무안공항 의 경우, 활주로 연장공사와 함께 KTX호남선의 공항 경유 계획 등이 완성되면 접 근성이 향상될 것이나, 향후 항공 여객수요 증가에 대비하여 대중교통 서비스의 확 충이 반드시 필요하다.

지방공항을 통해 입국한 외국인 관광객들의 지역관광 접근성 제고를 위해 항공과 
철도를 연계한 예약·발권 시스템을 구축하고 제휴 할인서비스 및 연계 관광상품 등 을 개발할 필요가 있다. 기존의 공항 리무진 및 일반버스의 경우, 지방공항의 국제 선 출·도착 시간에 맞춰 운행 스케줄과 배차 간격을 조정하는 방안을 검토할 필요가 있다. 가장 이상적인 것은 해당 지자체에서 지방공항을 통해 입국하는 외국인 관광 객들을 위한 셔틀버스 서비스를 제공하는 것이다. 공항연계 셔틀버스는 KTX역, 버 스터미널 등 시내 교통거점을 비롯하여 유명호텔, 주요 관광명소 등을 경유하도록 노선을 개발할 필요가 있다.

지방공항에서 버스나 지하철 등 대중교통수단으로 접근하기 어려운 관광지를 편 리하게 방문할 수 있는 대안으로 관광택시에 대한 수요를 고려할 필요가 있다. 외국 어 안내가 가능한 관광택시 운영 드라이버를 모집하여 기본적인 서비스 교육을 실 시하고, 필요에 따라서는 리무진 택시의 도입도 검토해볼 수 있다. 향후 개별여행시 장의 증가가 예상됨에 따라 항공과 연계한 렌트카 예약시스템을 구축하고, 공항 렌 트카 이용료 할인 행사(예: 최초 1 일 1만원 렌트카) 및 렌트카 여행을 위한 외국어 안내지도를 제공할 필요가 있다. 또한, 인천공항에서 대여한 렌트카를 다른 지방공 항에서도 반납할 수 있도록 하여 외래관광객들의 지방여행을 촉진할 필요가 있다. 공유차량 서비스의 경우, 현재 무안공항 내에서는 이용하기 어려워 개선 방안을 마 련할 필요가 있으며, 모바일 앱으로 차량 예약시 필요한 외국어 지원 서비스를 도입 할 필요가 있다.

[그림 5-4] 도심과 주요 호텔을 연결하는 공항셔틀버스

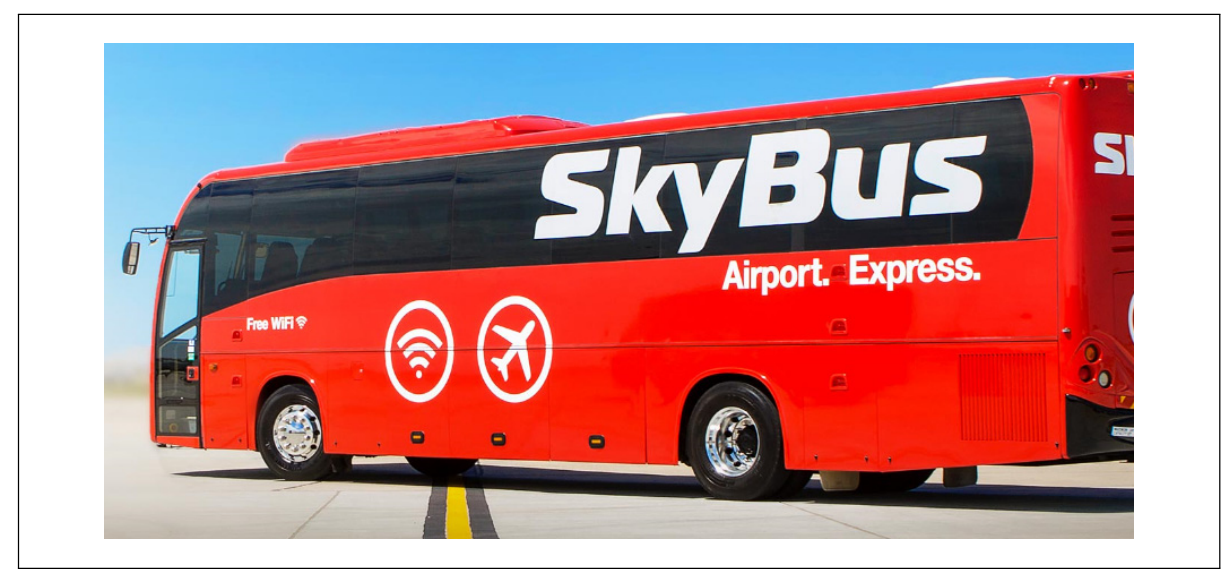

자료: 호주 멜버른 툴라마린 공항의 Sky Bus 


\section{다. 면세 및 쇼핑 만족 제고}

\section{1) 배경 및 필요성}

현재 외국인 관광객들이 우리나라를 방문하는 가장 큰 목적 중에 하나는 바로 쇼 핑이다. 매년 실시되고 있는 외래관광객(실태)조사에 따르면, 거의 대다수의 외국인 관광객들이 방한기간 중에 쇼핑활동에 참여하고 있으며, 주로 향수나 화장품, 식료 품, 의류, 신발 등을 많이 구입하는 것으로 나타났다. 또한 방한 외래관광객들의 주 요 쇼핑장소는 명동 로드샵이 가장 많지만, 공항 면세점과 시내 면세점을 이용한 비율도 증가를 보이고 있다.

본 연구의 주요 대상으로 삼았던 김해공항과 무안공항의 경우 국제선 터미널 출 국장 내에 외국인 관광객들의 쇼핑을 위한 공항 면세점이 입점해 있지만, 인천공항 이나 제주공항과 비교할 때 매장의 규모나 상품의 다양성 측면에서 부족한 점이 많 았다. 또한 김해공항과 무안공항 내에는 부산, 경남, 광주, 전남 등 공항 인근 도시 나 주변 지역의 대표적인 특산품이나 한국 지방여행을 기념하기 위한 물건을 구입 할 수 있는 상점을 찾기 어려웠다.

이번 연구에서 실시한 외국인 개별 심층면접 조사에서도 김해공항 이용 경험이 있는 외국인 가운데 공항 내 면세점 수가 적고 규모가 협소하다는 의견이 있었고, 무안공항에서는 한국 관광기념품 상점이 개설되면 좋겠다는 의견이 제시되었다. 향 후에는 지방공항 시설 내에서 뿐 만 아니라 공항 인근의 도시와 주변 지역에서 외국 인 관광객들이 큰 불편함 없이 만족스러운 쇼핑 활동을 경험할 수 있도록 개선을 위한 노력을 기울일 필요가 있다.

\section{2) 추진방안}

김해공항의 경우 향후 영남권 신공항 건설 추진이 이루어지게 된다면 국제선 및 국내선 터미널 내 확장된 쇼핑공간과 시설을 새롭게 도입할 수 있을 것으로 예상된 다. 이때 인천공항이나 외국의 주요 공항과 같이 해외 유명 브랜드 명품을 포함한 면세 쇼핑상점과 우리나라의 전통 수공예품, 관광기념품, 지역특산품 등의 상점이 잘 어우러질 수 있도록 계획해야 할 것이다. 호주 브리즈번 공항의 경우, 명품 면세 점 뿐 아니라 특산품 아울렛을 조성하여 시내보다 더 저렴하게 기념품 구입이 가능 
한 점도 참고할 필요가 있다.

무안공항의 경우 국제선 터미널 출국장 내 면세점이 입점해 있지만 규모가 매우 협소하고 상품이 다양하지 못한 실정이다. 현재 외래관광객들의 한국 방문 선택 시 중요한 고려요인이 쇼핑이며, 방한기간 중 주요 참여활동의 경우도 쇼핑이 가장 많 다. 이러한 점을 감안할 때, 무안공항 내 대형면세점이 조성될 수 있도록 장소 임대 료 등을 지원하여 쇼핑 목적의 방한 외래관광객을 지역으로 유치하는 전략을 검토 할 필요가 있다.

무안공항 내 면세점의 보완책으로는 광주, 목포, 여수 등 공항 인근 주요 도시에 시내 면세점을 설치 - 운영하는 방안을 검토해 볼 수 있다. 또한 개별여행객 시장을 타깃으로 할 경우 도심과 관광지에 즉시환급면세점을 포함한 사후면세점을 확대할 필요가 있다. 방한 외래객들의 주요 관광활동 중 하나가 식도락이며, 호남지역의 음 식 맛에 대한 평가가 좋은 만큼 전통음식이나 유명 먹거리, 다양한 식재료 등을 쇼 핑관광 상품으로 개발할 필요가 있다.

국내 지방공항을 활용하여 지역관광을 활성화하고 이를 통한 경제적 효과를 높이 기 위해서는 공항 인근 도시 및 주변 지역에서의 관광객 소비 지출을 확대할 필요가 있다. 해당 지자체에서는 전통 재래시장, 쇼핑거리, 쇼핑몰 등 대표적인 쇼핑관광 명소를 육성하고, 공항으로부터 편리하게 접근할 수 있는 대중교통 수단과 외국어 안내 정보를 제공할 필요가 있다. 또한, 외국인 관광객들이 지역 내 상점에서 쇼핑 한 수화물을 출국 공항까지 직접 배송해주는 서비스나, 한국 도착 시 공항 입국 면 세점에서 구입한 물품을 장기간 보관해주는 서비스, 공항 내 면세품 인도장, 세금환 급(Tax-refund) 부스, 24시간 운영 환전소 설치 등을 통해 쇼핑 만족도를 향상시 킬 수 있을 것이다. 


\section{3. 지역 연계 및 관광 활성화}

\section{가. 국제적인 관광매력 발굴}

1) 배경 및 필요성

현재 우리나라는 수도권과 제주도에 집중된 외래관광객을 지방으로 분산시키고 지역관광을 활성화시키는 것이 중요한 과제 중의 하나로 부각되고 있다. 방한 외래 관광객이 인천허브공항을 통해 입국한 비율이 $70 \%$ 에 다다르고 있으며, 김해공항과 제주공항 등 일부 공항을 제외한 국내 지방공항은 외래관광객의 입국 관문으로서 역할과 기능이 여전히 미미한 실정이다.

「2019 항공여객 OD 및 특성조사」 데이터 분석 결과에 따르면, 김해공항 이용 외국인 관광객들은 부산(85\%)을 가장 많이 방문하였으며, 경북(2\%)이나 경남(2\%) 지역을 방문한 비율은 매우 낮았다. 한편, 무안공항 이용 외국인 관광객들의 경우 전남(36\%)과 광주(33\%)를 많이 방문하였으며, 전북(4\%) 지역을 방문한 비율은 부 산(10\%)과 서울(5\%)보다도 낮게 나타났다.

최근 정부는 지역관광의 활성화를 위해 관광거점도시 육성사업, 테마 여행 10선, 지역 관광기업 지원사업 등 관련 정책개발과 후속사업을 적극적으로 추진하고 있 다. 국내 지방공항을 활용한 지역관광 활성화를 도모하기 위해서는 이러한 관광거 점도시들과의 연계 전략을 강화할 필요가 있으며 유네스코 등재 세계유산, 국제 문 화·관광 축제 등 외국인들의 관심과 인지도가 높은 관광명소와 매력 있는 콘텐츠를 보다 적극적으로 홍보할 필요가 있다.

\section{2) 추진방안}

본 연구의 주요 대상인 김해공항은 '대도시형 지방공항'의 관점에서, 무안공항은 '지역연계형 지방공항'의 관점에서 지역 연계 강화 및 관광 활성화 방안을 모색해 볼 수 있다. 우선, 김해공항의 경우 현재 부산시와 가장 밀접하게 운영되고 있는데 향후 국제관광도시 육성사업이 구체적으로 추진되게 되면 부산의 도시이미지와 관 광브랜드 구축을 위한 홍보마케팅 활동 거점으로서 공항시설 및 항공네트워크를 적 극적으로 활용할 필요가 있다. 
무안공항의 경우에는 지역관광거점도시로 지정된 목포시와 가장 인접하여 있는 데 근대역사문화지구, 해양문화관광특구 등을 연계한 시티투어 프로그램과 구도심 내 도보관광 코스 등을 적극 개발할 필요가 있다. 또 다른 지역관광거점도시인 전주 시는 무안공항에서 이동거리가 멀어 접근성은 다소 떨어지나, 지역 전통문화와 고 유한 음식 등 매력적인 관광콘텐츠를 보유하고 있어 외국인을 위한 한옥숙박 여행 상품 등을 개발해 볼 수 있다.

우리나라는 유네스코 등재 세계유산을 다수 보유하고 있으며 가장 대표적인 것이 불국사와 석굴암, 해인사 팔만대장경판 등이다. 현재 경상북도에서는 김해공항 터 미널 내 관광안내 데스크를 운영하고 있지만, 실제로 경북 지역을 다녀온 외국인 관광객 수는 매우 미미한 것으로 조사되었다. 따라서 사전에 해외 웹 사이트나 SNS 등을 통해 한국의 세계유산을 널리 홍보하고, 지방공항을 통해 입국한 외국인들이 보다 가깝고 편리하게 세계유산 지역을 여행할 수 있도록 옵션투어나 직통 교통수 단을 개발할 필요가 있다.

또한, 김해공항의 경우 해외에 잘 알려진 부산국제영화제나 K-pop 한류공연 이 벤트 등을 활용하여 국적 항공사 및 방송사, 해외 현지 여행사 등과 협력하여 동남 아 관광객 유치를 위한 전세기 방한상품을 개발할 필요가 있다. 한편, 무안공항은 해남관광단지(오시아노), 진도 쏠비치 등 주변 관광지와 연계 가능하며, 신안군 앞 '섬 여행', 여수 금오도 ‘트레킹' 등 외국인 개별여행객들의 선호가 높은 액티비티 중심의 상품을 개발해볼 수 있다.

[그림 5-5] 부산 국제관광도시와 신안군 섬 어드벤처
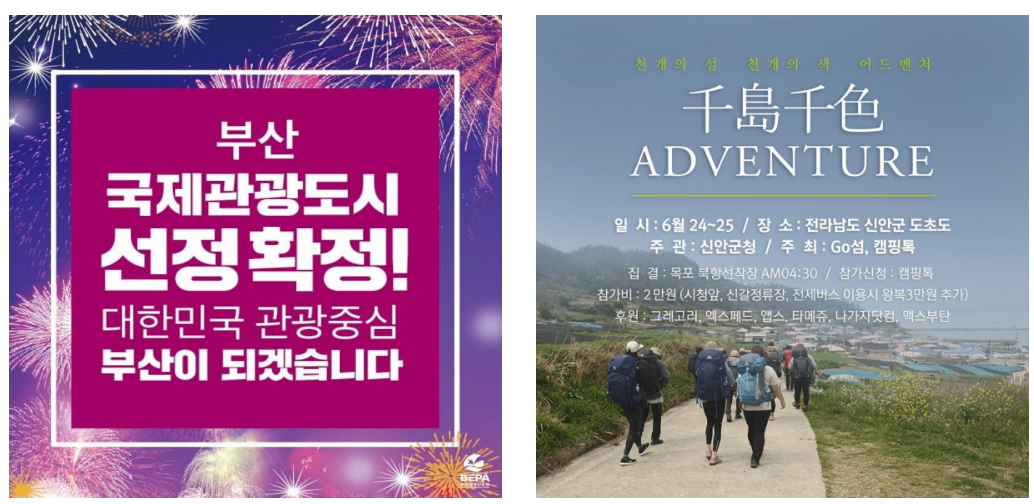


\section{나. 지방공항의 지역명소화}

1) 배경 및 필요성

본 연구의 주요 대상인 김해공항과 무안공항을 직접 방문하여 조사한 결과, 공항 내 편의시설이나 서비스, 프로그램 등이 국내 다른 공항이나 지역과 뚜렷이 구별될 수 있는 특징을 갖고 있지 않았다. 예를 들어 김해공항이나 무안공항의 국제선 터미 널 내 식당, 카페, 상점 등은 서울 수도권이나 타 지역에서 흔히 볼 수 있는 프랜차 이즈 계열이었고, 현지 고유한 산업이나 먹거리 등과는 거리가 멀었다. 또한 국내 지방공항이 지역의 중요한 SOC 교통 거점시설이지만, 인근 도시 및 지역 주민들과 의 활발한 교류나 상호 협력 활동이 잘 이루어지지 않고 있는 실정이다.

한편, 국토교통부는 「제 3 차 항공정책기본계획」에서 공항을 단순 교통인프라가 아닌 지역의 신산업·기업 성장의 플랫폼으로 구축한다는 전략 방향을 제시한 바 있 다. 이를 위해 공항의 경쟁력 강화 및 지역주민 편의 제고를 위한 연계교통 접근성 을 개선하고, 공항을 지역 커뮤니티 SOC로 확장할 계획을 갖고 있다. 또한, 공항 인프라와 지역의 특별한 산업·문화·관광자원을 활용하여 해당 공항과 지역에만 있 는 볼거리, 공항과 지역을 상징하는 핵심 이미지와 가치 등 공항별 브랜드 창출을 추진할 계획이다.

국제관광 측면에서는 지방공항이 단순히 국가 간 이동을 위한 항공교통 시설일 뿐 만 아니라, 방한 여행의 첫 시작점이자 그 지역과 도시를 상징하는 매력 있는 장소로서 거듭날 수 있도록 공항의 특성화 사업을 적극 추진할 필요가 있다.

\section{2) 추진방안}

우선, 국내 지방공항이 입지하고 있는 배후지역과 인근도시의 고유한 산업, 브랜 드 이미지, 대표적인 문화유산 및 자연자원 등을 조사할 필요가 있다. 해당 지자체 가 추구하는 도시 이미지 및 관광 브랜드 방향을 고려하여 공항 내 주요 시설과 서 비스, 프로그램 등을 차별화할 필요가 있다. 김해공항의 경우 영남권 신공항 건설이 추진된다면, 공항의 브랜드 창출 및 지역명소화 사업에 용이한 여건이 마련될 것으 로 판단된다.

해외 한류의 인기가 한국 이미지와 방한 의향을 높이는데 큰 기여를 하고 있으며, 
때문에 한류는 국내 지방공항의 지역명소화 사업의 좋은 아이템이 될 수 있다. 예컨대 부산의 해양관광도시 이미지나 부산국제영화제, 한류 영상촬영지 등을 강조함으로써 김해공항을 이용하는 외국인 관광객들에게 깊은 인상을 심어 줄 수 있다. 외국의 유사 한 사례로 뉴질랜드의 수도 웰링턴 공항은 영화 반지의 제왕을 연상시키는 내부 시설 인테리어로 그 지역의 경쟁력 있는 영화산업을 효과적으로 잘 홍보하고 있다.

한편 무안공항의 경우 배후도시인 광주와 전남지역의 색깔을 뚜렷하게 홍보할 수 있는 브랜드 창출 전략이 요청된다. 호남의 맛과 음식문화를 경험할 수 있는 식당, 지역특산품이나 고유한 식재료를 구입할 수 있는 상점, 대기시간을 활용하여 한국 전통문화를 체험해볼 수 있는 프로그램 등 공항을 이용하는 외국인들을 위한 세심 한 배려와 환대가 중요하다. 외국의 한 예로, 호주 멜버른 공항은 패션의 도시답게 대표 패션 브랜드 매장을 비롯해 다양한 음식점이 입점하면서 쇼핑의 장으로 명성 을 높이고 있다.

향후에 지방공항은 주변지역의 관광 및 산업 개발이 함께 이루어져야 한다. 특히, 공항경제권의 개념을 도입하여 통합적인 주변지역 개발 추진이 필요하다. 김해공항 의 경우 그 배후지역이 인바운드 관광수요를 창출할 수 있는 가능성이 있으며, 부산 뿐 아니라 광역권 차원에서 지역의 관광자원들을 연계하고 최대한 활용할 필요가 있다. 공항 주변의 복합도시 공항경제권이 활성화된다면 인바운드 여객 증대에도 긍정적 영향을 가져올 수 있다. 일례로 네덜란드의 스키폴, 독일의 프랑크푸르트 등 은 공항 주변의 관광, 숙박, 상업시설을 개발하여 환승객 유치를 도모하고 있다.

[그림 5-6] 싱가포르 창이공항의 Forest Valley와 Rain Vortex

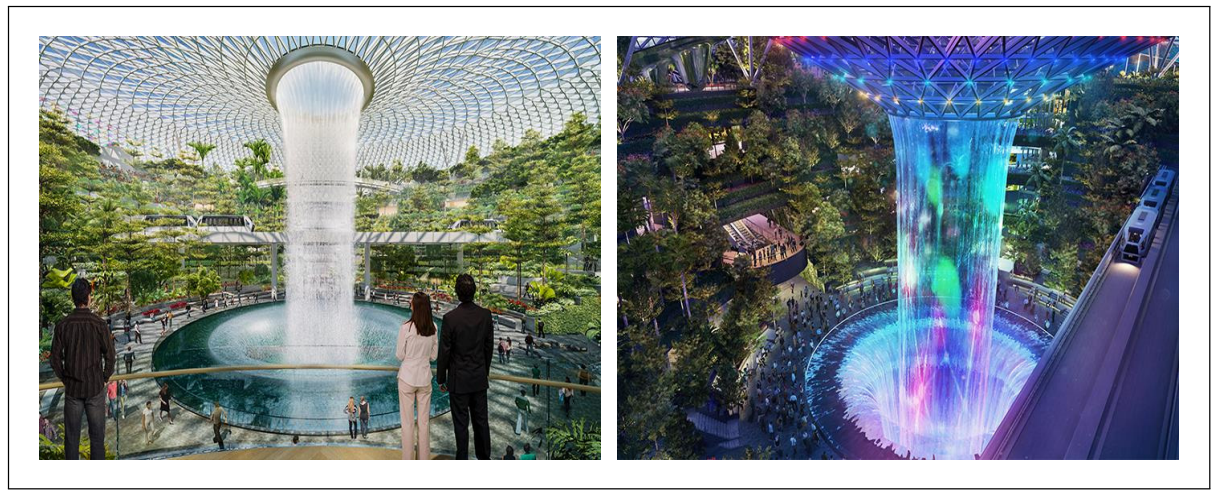

자료: Changi Airport 


\section{다. 해외 현지 마케팅 강화}

1) 배경 및 필요성

우리나라 전체 외래객의 약 $90 \%$ 가 공항을 통해 입국하고 있으며, 다른 교통수단 에 비해 항공 서비스의 비중이 최근 증가 추세를 보이고 있다. 그러나 정부의 인천 공항 허브화 전략은 방한 외래관광객들의 서울 수도권 편중 문제를 심화시킬 우려 를 낳고 있다. 실제로 인천공항을 통해 입국한 외래객 비중이 전체의 약 $70 \%$ 에 이 르고 있다. 국내 지자체들 간의 관광시장 유치 경쟁이 심화되고 있는 상황에서 공항 시설을 보유한 지자체의 경우 교통서비스 측면에서 매우 유리한 조건을 갖고 있다 고 볼 수 있다.

지방공항을 활용하여 방한 외래관광객들을 유치하기 위해서는 해외 현지 홍보 마 케팅을 보다 공격적으로 추진할 필요가 있다. 수도 서울과 인천허브공항에 비해 부 산, 광주, 목포 등 중·소도시와 김해공항, 무안공항 등 지방공항은 해외 인지도나 관광 브랜드가 부족할 수 밖에 없다. 실제로 본 연구에서 실시한 외국인 개별 심층 면접 조사에서도 김해공항과 무안공항이 좋은 시설을 갖추고 있으나 외국인들은 잘 알고 있지 못하며, 공항 배후의 중·소도시 홍보를 위한 노력이 필요하다는 의견이 제시되었다.

따라서, 해당 지자체에서는 지방공항의 국제노선을 활용하여 더 많은 외국인 관 광객을 유치하기 위한 해외 홍보 마케팅 활동을 주도적으로 추진할 필요가 있다. 또한 지방공항에서 운항 중인 항공사 입장에서는 아웃바운드 내국인 수요 뿐 아니 라 인바운드 외국인 수요를 창출하여 충분한 여객시장을 확보하기 위한 현지 마케 팅을 강화할 필요가 있다. 향후 우리나라 항공시장은 아웃바운드 수요에만 의존해 서는 지속적인 성장을 기대하기 어렵다는 점을 인식하고 인바운드 관광 활성화를 위해 협력할 필요가 있다.

\section{2) 추진방안}

정부와 지자체는 지방공항에서 취항 중인 항공사와 협력하여 해외 미디어 및 여 행사, SNS 인플루언서 등 대상으로 초청 팸투어를 추진할 필요가 있다. 태국의 경 우, 태국관광청과 여러 항공사 간의 연합으로 전 세계 여행사, 언론매체 등을 대상 
으로 메가 팸투어를 개최하여 지방의 새로운 목적지들을 홍보한 바 있다. 또한 현재 까지는 방한 외래관광객 유치 확대를 위해 현지 여행업계나 언론사 등을 대상으로 초청 팸 투어를 진행해왔지만, 외국정부 및 외국국적 항공사를 대상으로 추진하는 것은 다소 소홀하였다. 한국관광공사 해외 지사와의 협력, 특히 한국공항공사와 지 자체가 함께 적극적인 마케팅 활동을 추진하는 것이 필요하다.

김해공항과 무안공항의 경우, 지방관광공사 및 문화/관광재단에서 한국공항공사 및 항공사와의 협력사업을 적극 발굴하여 추진할 필요가 있다. 국내 유사한 사례로, 대구관광뷰로에서는 티웨이항공, 에어부산과 함께 캠페인을 전개하였는데, 항공사 에서는 좌석 블록과 할인된 항공 가격을 제공하고 대구관광뷰로와 공동으로 온라인 홍보 마케팅을 진행하였다. 국내 주요 방송사, 저비용항공사 등과 함께 BTS와 같은 한류스타의 지방공연 이벤트를 이용한 방한 관광상품을 개발하는 것도 지방공항을 연계 활용하는 좋은 방안으로 판단된다.

또한 정부와 해당 지자체에서는 지방공항 및 항공사, 여행사 등이 공동으로 해외 현지의 소비자 대상 광고와 마케팅 활동을 전개할 수 있도록 재정적인 지원 방안도 검토해 볼 수 있다. 호주 퀸즈랜드 주에서는 항공노선 유치 투자기금(AAIF)을 지원 하고 있는데, 이를 참고하면 민간 항공사에 대한 직접적인 재정 지원 방식보다는 한국관광공사나 지방관광공사의 해외지사 조직을 통하여 항공사 및 현지 여행사, 주요 방송사 등이 참여하는 공동 홍보 마케팅 사업을 지원하는 방식이 효율적일 것 으로 판단된다.

지방공항의 국제노선 신규취항 및 증편을 지원하기 위한 공항 세일즈 지원 정책 을 추진할 필요가 있다. 한국관광공사는 해외지사를 통해 공항 세일즈에 필요한 정 보를 수집하여 지자체와 공항공사 등에 제공하고, 각국의 주요 항공사 및 공항 등이 모이는 국제전문상담회에 참석을 지원해야 할 것이다. 또한, 국내 지방공항에서는 해외 주요 공항들과 신규 항공사 및 노선 유치를 위한 공동 마케팅 협약을 체결할 필요가 있다. 양 공항 간의 항공사 신규 취항 및 노선 확대를 지원하고, 해당 노선을 이용하는 여객과 환승객 증대 등 노선 활성화를 위해 공동의 마케팅 노력을 기울일 필요가 있다. 상대국 취항공항에서 자국의 지방공항 및 관광자원을 홍보하고, 양국 간 직항노선을 운항 중인 항공사와 협력하여 기내 광고를 추진하는 등 효과적인 마 케팅 전략이 요청된다. 


\section{제3절 주체별 역할과 협력방안}

\section{1. 관광-항공 협력체계 필요성}

관광과 항공은 관광산업 생태계 측면이나 항공산업 생태계 측면에서 연관성이 매 우 크다. 실질적으로 섬나라의 성격을 가진 우리나라는 방한 외래객 중 $90 \%$ 이상이 항공교통을 이용하여 입국하고 있다. 하지만 우리나라의 경우 관광정책은 문화체육 관광부에서 항공정책은 국토교통부에서 담당하고 있으며, 관광정책과 항공정책의 우선순위는 다소 차이가 존재한다. 이런 관점에서 두 분야 간의 차이를 좁히고 상호 윈-윈 할 수 있는 방안 모색이 필요하다.

〈표 5-4〉 관광 및 항공부문의 정책 격차

\begin{tabular}{c|c|c}
\hline 구분 & 관광부문 & 항공부문 \\
\hline \multirow{2}{*}{ 항공노선 정책 } & $\begin{array}{c}\text { 지방공항 균형 배분 } \\
\text { 관광항공 노선 정책 }\end{array}$ & $\begin{array}{c}\text { 인천국제공항 허브화 } \\
\text { 국민 교통편의성 증진 }\end{array}$ \\
\hline 항공협정 & 방한 외래관광객 증대 중점 & 국적항공사 및 공항보호 우선 \\
\hline 지방공항 활성화 & 지역관광 활성화 우선 & 지방공항 항공운송 증대 필요 \\
\hline 항공사 & 국적사·외항사 비차별 & 국적항공사 우선 \\
\hline 환승 & Stop-over 필요 & Transit 및 Transfer 무방 \\
\hline 환승관광 & 한국관광공사 주도 & 공항공사 주도 \\
\hline
\end{tabular}

자료: http://wmw.ttlnews.com/article/travel_report/3261 연구자 재수정

지금까지 관광과 항공분야는 민간합동 항공-관광발전 협의체 구성, 관광-항공 정 책협력 협의회 운영, 관광-항공 협력포럼 개최 등 다양한 협력을 추진하였다. 이를 통해 부처 상호 간의 정책을 공유하고 과제도 발굴하며 일부분 성과도 달성했다. 하지만 아직 여러 가지 측면에서 협력 성과가 부족하며 많은 제한이 존재하고 있다.

2017년부터 매년 2회 개최되는 국가관광전략회의는 국무총리 주관 하에 국토교 
통부 장관도 위원으로 포함되어 있다. 이러한 장을 통해 관광과 항공 분야 간의 정 책 격차를 좁히고 지방공항의 활성화 및 인바운드 시장의 유치를 위한 정책을 추진 할 필요가 있다. 앞으로는 단순한 부처 간의 정보 공유를 넘어 부처의 의사결정에 영향을 미칠 수 있어야 하며, 통합적이고 일관성 있는 정책의 추진이 이루어져야 할 것이다.

전국의 8개 국제공항중 인천공항과 김포공항을 제외한 6 개 공항별 외래관광객의 유치 확대를 위해서는 관광과 항공 부문간 협력체계를 구축하는 것이 중요하다. 나 아가 중앙정부 차원과 지자체 차원, 공공부문과 민간부문 등 다각적인 협력체계를 구축하는 것이 필요하다. 그럼에도 지방공항을 활용한 관광활성화의 ‘추진체계'는 지자체, 지방공항, 지역의 항공사 및 관광업계, 그리고 지방공기업의 주도적인 참여 를 통하여 소기의 성과를 거둘 수 있을 것이다. 또한 중앙정부 및 산하 공기업의 경우 '지원체계'로서의 역할을 담당할 수 있다.

[그림 5-7] 지방공항 관광활성화 협력체계(안)

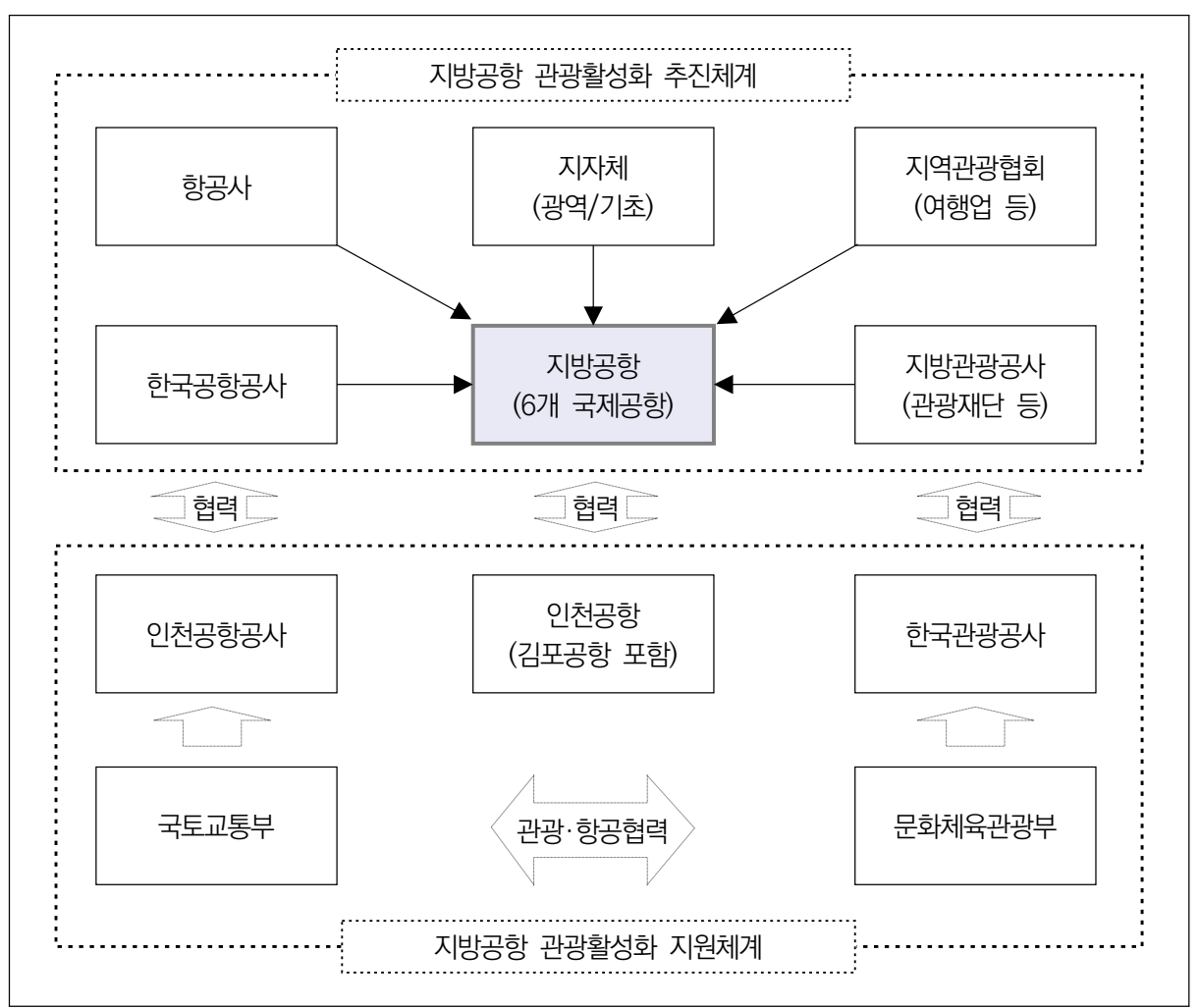




\section{2. 각 주체별 역할과 협력방안}

지방공항의 관광활성화를 위한 이해당사자별 역할은 1) 중앙정부 및 산하 공공기 관의 역할, 2) 전국 국제공항간 협력 역할, 3) 지자체 및 지역관광 공기업의 역할, 4) 지방공항 취항 항공사의 역할, 5) 지역관광협회(여행사 등)의 역할 등 다섯 가지 로 살펴볼 수 있다.

\section{1) 중앙정부 및 산하 공공기관의 역할}

중앙정부 및 산하 공공기관은 외래관광객의 유치, 지방공항을 연계한 지역관광의 활성화, 지방공항 연계 관광상품 발굴 및 공동홍보 강화, 공항에서 도심(관광지)간 교통 및 안내서비스 개선, 지방공항의 인바운드 기여도 제고, 지방공항의 출도착 거점 기능의 확대, 관광항공 관련 산업의 육성, 외래객의 지역접근성 개선 및 관광교통 편의 확대, 지역 기반시설의 관광자원화 사업 등을 추진하여야 한다. 특히 정부기관 들은 외국인의 지방공항 이용 활성화에 보다 많은 공동노력을 전개하여야 한다.

그리고 중앙정부의 산하기관인 한국관광공사, 한국공항공사 및 인천공항공사는 외국항공사의 유치, 지방공항의 시설 개선 및 서비스 인프라의 개선, 지방공항 관 광지간 이동성 개선, 국제관광 홍보, 지방공항 입국자의 식별정보 공유, 최적화된 홍보마케팅, 동남아 및 일본 시장 특별 홍보 및 프로모션 전개 등을 담당할 필요가 있다. 특히 한국공항공사 및 인천공항공사는 외국 공항과 국내 지방공항 간 네트워 크 구축 및 홍보에 역점을 두어야 하며, 한국관광공사는 지방공항과 주변 관광지간 이동편의 증진, 스마트 관광시스템 조성에 역점을 두어야 한다.

\section{2) 국제공항간(수도권과 지방권 공항)의 협력 역할}

전국의 전체 15 개 공항중 8 개의 국제공항이 있으나 인천공항을 통한 외래객의 입국 비중이 2013년의 58.1\%에서 지속적으로 증가하여 2019년에는 66.7\%에 다 다랐다. 나머지 지방공항중 김해공항과 대구공항은 그 비중과 입국자수가 꾸준히 증가하고 있으나 제주공항, 청주공항, 무안공항, 양양공항은 비중도 감소하고 입국 자수도 감소하고 있다. 
지방공항의 활성화에 있어서 인천공항(김포공항 포함)의 역할은 외래관광객의 집 산(集散) 기능 중 '집중'에만 초점을 두어왔을 뿐 외래객의 '분산' 기능에 대해서는 상대적으로 소홀하였다. 따라서 인천공항과 제주공항 및 김해공항, 김포공항과 나 머지 국제공항간 연계 항공편 개설을 통하여 외국인의 지방공항 출입을 확대할 필 요가 있다.

나아가 8개 국제공항간 인(In)-아웃(Out) 기능을 교차 수행하는 방안도 확대되어 야 한다. 영남권의 경우 김해공항으로 입국하고 대구공항으로 출국하거나 그 반대 의 형태도 이루어질 수 있도록 유도하여야 한다. 그리고 인천공항(김포공항 포함)과 제주공항간 인-아웃 기능도 활성화될 필요가 있다. 기존에 청주공항을 통해 입국하 고 수도권 공항으로 출국하는 형태도 더욱 확대되어야 한다.

\section{3) 지자체 및 지역관광 공기업의 역할}

외래관광객의 지역분산 방식은 두 가지 관점에서 살펴볼 수 있다. 하나는 허브앤 스포크(Hub \& Spoke) 방식에 의거 수도권 방문객의 지방방문을 유도하는 사업이 며, 다른 하나는 포인트투포인트(Point to Point)의 형태로 지방의 독자적인 외래 객 유치 역량을 확보하는 것이다. 비용·편의 관점에서 보면 전자가 효율적일 수 있 으나 지역의 입장에서는 아직 성과가 나타나지 않고 있다는 점에서 후자의 방식도 병행할 필요가 있다. 특히 지자체들의 지역내 공항 활성화를 위한 노력이 확대되어 야 하며, 이를 위해 실무적인 기능을 해당지역 공기업이 수행할 수 있도록 유도해야 한다.

현재 서울관광재단, 강원관광재단, 전남관광재단, 제주관광공사, 부산관광공사, 인천관광공사 등 대부분의 지역에는 관광관련 공기업이 설립되어 있으나 대구공항, 청주공항 등 일부 지역의 경우에는 지방공항과 지역관광 공기업간의 협력사업이 진 행되지 못하고 있다. 특히 2020년 1월 발표된 관광거점도시 사업과의 연계사업도 적극 추진되어야 한다. 기존 지방공항 허브항공사 연계 제도 외에 지방공항 거점 관광도시 연계사업도 신규로 추진될 필요가 있다. 


\section{4) 지방공항 취항 항공사의 역할}

지방공항이 활성화되기 위해서는 공항별 허브항공사를 적극 육성하고 지역자본 의 참여 확대를 통하여 외래관광객 유치와 해외노선 확충을 추진해야 한다. 무엇보 다 지방공항을 활용한 관광.항공 협력사업의 가장 중요한 과제는 방한관광 항공노 선의 확대이다. 단기적으로는 한.중-일간 노선의 확대뿐만 아니라 동남아 지역으로 노선을 다변화하여 지방공항이 동북아 및 동남아권 외래객의 주요 방문거점으로 육 성될 필요가 있다.

이를 위해 지방공항 기반 허브항공사의 유치를 도모하여 지방공항 운수권을 제공 하고 항공사의 지방공항 운항을 유도하며, 신규 취항 및 증편시 인센티브를 제공하 여야 한다. 그동안의 지방공항 항공노선 이용현황을 보면 일부 공항의 경우 내국인 이 90\%를 차지하고 있다는 점에서 외래관광객의 유치를 위한 해외 홍보 및 마케팅 을 적극 추진하여야 한다. 그리고 지방공항을 취항하는 항공기를 활용한 지역 관광 거점도시의 홍보사업도 적극 추진될 필요가 있다.

\section{5) 지역관광협회(여행사 등)의 역할}

현재 중앙정부 차원에서 문화체육관광부와 국토교통부, 산하 한국관광공사와 한 국공항공사, 관광과 항공분야 업계가 참여하는 '관광.항공 정책협의회'를 구성하여 운영하고 있다. 그러나 관광·항공 부문간 협력이 지방공항의 활성화 및 외래객의 지 역분산에 초점을 두고 있다는 점에서 중앙정부 차원에서만 추진되어서는 안 되며 해 당 지자체, 국내외 항공사, 지역관광진흥기구(RTO), 지역관광협회 등을 아우르는 지 방공항별 '관광·항공협력 추진협의회'가 활발히 운영되어야 한다. 그럼에도 지방공 항의 관광활성화 사업에 대한 지역 관광업계의 참여수준은 여전히 저조한 상황이다.

무엇보다 지방공항을 활용한 지역관광의 활성화를 위해서는 지역관광업계를 중 심으로 지역별 글로벌 관광명소의 육성 및 콘텐츠의 지속적인 발굴이 필요하다. 외 래관광객이 선호하는 우수 관광콘텐츠를 지속 발굴하고 상품화하는 것이 중요하다. 일차적으로 지방공항과 지역의 관광자원을 연계한 테마형 고부가가치 관광상품을 개발하며, 의료, 웰니스, K-Pop, 한류 및 공연, 스포츠 등 '1지역 1 특화 1 고부가 관광상품'의 개발이 필요하다. 이밖에도 기존에 정부가 추진하고 있는 테마여행 10 선 사업, 한국관광 유니크베뉴(Unique Venue) 사업과의 연계도 모색되어야 한다. 

지방공항을 활용한 지역관광 활성화 방안

\section{제6장}

결론 



\section{제1절 결론}

전체 방한 외래관광객의 $90 \%$ 이상이 공항을 통해 입국하고 있으며 국제관광에 있어서 항공교통의 중요성이 점점 커지고 있다. 그러나 국토교통부의 인천공항 허 브화 전략은 방한 외래관광객들의 서울 수도권 방문 집중을 심화시킬 우려를 낳고 있다. 실제로 방한 외래관광객이 인천공항을 통해 입국한 비율이 약 $70 \%$ 에 이르고 있으며 김해공항과 제주공항 등 일부 공항을 제외한 지방공항은 입국 관문으로서 역할과 기능이 미미한 실정이다.

지금까지 지방공항의 국제노선은 우리 국민의 아웃바운드 수요와 선호 목적지를 중심으로 직항노선과 운항편수가 배분되어 온 경향이 많았다. 또한 지방공항은 기 본 편의시설과 서비스를 갖추고 있으나 외국인을 위한 안내정보 서비스가 미흡하 고, 공항 배후도심 및 주변 관광지까지 연결하는 대중교통 수단이 불편하여 시급한 개선이 요청된다.

본 연구에서는 지방공항을 활용한 방한 외래관광객 유치 강화 및 지역관광 활성 화를 위하여 주요 핵심 영역을 세 개로 구분하고 총 9개의 정책과제를 제시하였다. 우선, 지방공항의 인바운드 여객수요 창출을 위해 국제노선 공동 개발, LCC 및 외 항사 유치, 환승관광객 유치 확대 등의 정책 추진이 필요하다. 지방공항 이용시 편 의성 제고를 위해서는 외국어 안내정보 서비스, 공항 연계교통 서비스, 면세 및 쇼 핑 등의 개선 과제를 제시하였다. 또한 지방공항과 지역 간 연계를 강화하고 관광을 활성화하기 위해서는 국제적인 관광매력 홍보, 지방공항의 지역 명소화, 해외현지 마케팅 강화 등의 정책을 추진할 필요가 있다.

향후 관광과 항공부문 간의 협력 정책은 단순히 방한 외래관광객 유치 확대에 초 점을 두기 보다는 지역관광을 활성화하기 위한 방향으로 재설정하여야 한다. 관광 과 항공부문의 다양한 주체들 간 역할 분담과 협력 방안을 강구할 필요가 있으며, 
기존 정부 주요 계획 및 중점 사업들과 연계하여 정책의 시너지 효과를 창출해야 할 것이다. 지역에서는 관련 지자체가 주도적으로 관광-항공 협력 거버넌스를 구축 하고 각 공항별 시장과 여건에 맞는 정책과 전략을 마련해야 할 것이다. 특히, 관광 부문에서는 국제적으로 매력 있는 지역 명소를 육성하고 경쟁력 있고 차별화된 관 광콘텐츠를 지속 발굴하여 상품화해야 할 것이다. 


\section{제2절 후속 과제}

관광·항공 부문 간 협력 사업의 지속적인 성과를 창출하기 위해서는 방한 외래객 들의 지방공항 이용 현황에 대한 체계적인 실태조사를 추진할 필요가 있다. 「2019 외래관광객 조사」의 경우 국내 8 개 국제공항 가운데 인천공항, 김포공항, 김해공항, 제주공항, 청주공항, 대구공항 등 6곳에서만 조사가 이루어졌다. 한편 「2019 항공 여객 $\mathrm{OD}$ 및 특성조사」의 경우 인천공항, 김포공항, 김해공항, 제주공항, 청주공항, 대구공항, 무안공항 등 7곳에서 조사가 실시되었다. 인천공항, 김포공항, 제주공항 은 지자체에서 자체적인 조사가 진행되고 있으나, 김해공항, 대구공항, 양양공항, 청주공항, 무안공항은 실태조사가 이루어지지 않고 있다.

정부가 매년 실시하고 있는 외래관광객 조사에서는 지방공항 입국자나 수도권 입 국자 중 지방 방문자 현황에 대한 구체적인 정보를 파악하는 것이 어려운 실정이다. 따라서 한국관광공사와 한국공항공사는 지방공항별 외래관광객 실태조사를 지속적 으로 추진할 필요가 있다. 각 지방공항을 이용한 외래관광객의 인구 통계적 특성 및 출·입국 현황, 주변 도시 및 관광지 방문 현황, 숙박시설 이용 현황, 대중교통수 단 이용 현황, 공항 시설 및 서비스 만족도 등에 대한 과학적 조사연구를 토대로 각 공항별 추진전략을 수립할 필요가 있다.

향후 항공과 관광부문이 협력하여 지방공항의 국제노선을 공동으로 개발함에 있 어, 기존의 중국과 일본 시장에 대한 의존도를 낮추고 동남아 등 전략시장 국가를 대상으로 노선 다변화 전략을 수립하기 위해서는 사전 연구가 필요하다. 사전 연구 를 통해 인바운드 관광 유치 확대가 필요한 전략시장 국가들을 우선 선정하고, 주요 도시별 인구규모, 소득수준 등을 분석하여 아웃바운드 송출 잠재력이 높은 도시를 중심으로 노선을 개발할 필요가 있다. 



\section{참고문헌}

- 강원도청(2018), 양양공항 동남아 단체관광객 무비자기간 연장 확정, Available: ht tp://www.provin.gangwon.kr/gw/portal/sub04_05_01?mode=readForm\&a rticleSeq=20180424174855335.

- 강원도청(2018), 양양공항 동남아 단체관광객 무비자입국 시행, Available: http:// www.provin.gangwon.kr/gw/portal/sub04_05_01?mode=readForm\&articl eSeq=20180110172408714.

- 강원도청(2018), 양양공항 동남아 하늘길 확 열린다!, Available: http://www.prov in.gangwon.kr/gw/portal/sub04_05_01?mode=readForm\&articleSeq=201809 03164233786.

- 관계부처 합동(2015), 「관광산업 육성 방안」.

• 관계부처 합동(2017), 「관광시장 동향 및 활성화 방안」.

- 관계부처 합동(2019), 「2020년 경제정책방향」.

- 관계부처 합동(2019), 「여행자 중심 지역관광 발전전략」.

- 국토교통부(2015), “지방공항 새 활로 찾기” 추진, Available: http://www.molit.g o.kr/USR/NEWS/m_71/dtl.jsp?id=95075924.

- 국토교통부(2015), 「지방공항 활성화 방안」.

- 국토교통부(2018), 「제5차 공항개발 중장기 종합계획」.

- 국토교통부(2019), 「제3차 항공정책기본계획(20 24)」.

- 국토교통부(2019), 「항공산업 경쟁력 강화 방안」.

- 국토교통부(2020), 「2019 항공교통서비스 보고서」.

- 김기성(2017.1.23), 호주공항에 얼굴 등 생체인식 시스템 '세계 최초' 도입, Availa ble: https://www.yna.co.kr/view/AKR20170123075600093.

- 문화체육관광부·국토교통부(2018), 제1회 관광·항공 협력포럼 자료집.

- 문화체육관광부·국토교통부(2019), 제 2 회 관광·항공 협력포럼 자료집.

- 신익수(2015.11.23), [트래블 라운지] 무비자 확대로 지방공항이 뜬다, 「매일경제뉴 스, B11. 
- 이재호(2019), 「최근 태국 경제 현황 및 한국·태국 경제협력 방향」, 세종 : 대외경제 정책연구원.

- 이지영(2018.5.3.), [김해공항 환승관광 유치 노력] "일본 가는 中 관광객, 부울경 들러 놀다 가세요”, 「부산일보」, 19.

- 장병권(2020), “관광항공 협력강화와 지방공항 활성화 방안", 계간 한국관광정책 제 79 호.

- 전라남도청(2018), 남도한바퀴, 외국인 전용 특별상품 운행, Available: https://www.jeonnam.go.kr/M7116/boardView.do?seq=1940491 \&menuId=jeonnam0202000000\&boardId=M7116.

- 전라남도청(2019), 무안공항 출발 외국인 '남도한바퀴' 빵빵, Available: https://www.jeonnam.go.kr/M7116/boardView.do?seq=1943001 \&menuId=jeonnam0202000000\&boardId=M7116.

- 전효재 외 3인(2018), 「항공산업과 연계한 관광산업 발전 전략 연구」, 한국관광공사.

- 정란수(2019), 「지역완결형 관광 활성화 사업 추진을 위한 지방공항 및 배후지역 관 광지 육성방안」, 한국관광공사.

- 제주관광공사(2019), 동남아 개별관광객 유치 마케팅 본격 추진, Available: https: //ijto.or.kr/korean/Bd/view.php?btable=report_info\&bno=1730\&p=1\&lcate.

- 태국 주요 5공항에 '중국인 전용' 입국 심사대 개설(2018.9.13), 「교민잡지」.

- 통계청(2018), 「항공통계 이용자용 통계정보보고서(2018년)」.

- 한국공항공사(2019), 항공통계: 공항별, 국제선 노선별, 항공사별 통계.

- 한국관광공사(2016), 태국관광공사, 여성 관광객 유치 캠페인 론칭, Available: https://kto.visitkorea.or.kr/kor/notice/data/mast/global/dnajdsj/ board/view.kto?id=426941\&rnum=137.

- 한국관광공사(2018), 태국관광공사, 300여명 규모 메가 팸투어 실시, Available: https://kto.visitkorea.or.kr/kor/notice/data/mast/global/dnajdsj/ board/view.kto?id=429038\&instanceId=280.

- 한국항공협회(2019), 「2019 항공여객 OD 및 특성조사 보고서」.

- Airports Of Thailand, (2020), AOT ready to halve landing and parking fees to lure more flights, Available: https://www.airportthai.co.th/en/.

- Brisbane Airport, 2018. 01. 24, Brisbane Airport and TravelbyBit launch world-first digital currency airport terminal, Available: https://newsroo 
m.bne.com.au/brisbane-airport-and-travelbybit-launch-world-first-digit al-currency-airport-terminal/.

- Brisbane Airport, 2020. 01. 24, Brisbane in hot pursuit of North American visitiors, Available: https://newsroom.bne.com.au/brisbane-in-hot-pursu it-of-north-american-visitors/.

- Canberra Airport, 2018. Contour 556 a natural fit for Canberra Airport, Available: https://www.canberraairport.com.au/news/contour-556-a-nat ural-fit-for-canberra-airport/.

- Destination NSW, 2015. 11. 25, NSW Government signs agreement with xiamen airlines to boots visitor number from China, Available: https://w ww.destinationnsw.com.au/wp-content/uploads/2015/11/20151125-nswgovernment-signs-australias-first-agreement-with-xiamen-airlines-to-bo ost-visitor-numbers-from-china.pdf.

- Nicole Hasham, 2016. 05. 04, The Sydney Morning Herald, Government plan lets you skip airport queues - if you are willing to pay, Available: https://www.smh.com.au/national/government-plan-lets-you-skip-airpo rt-queues--if-you-are-willing-to-pay-20160504-golxvu.html.

- Tourism Authority of Thailand, 2017. 08. 01, Women's Journey Thailand 2017 Campaign launched to boost female visitors, Available: https://ww w.tatnews.org/2017/08/womens-journey-thailand-2017-campaign-launc hed-to-boost-female-visitors/.

- Tourism Authority of Thailand, 2017.11.17, Over 300 travel agents and media set to discover New Shades of Thailand on Mega Fam Trip, Availa ble: https://www.tatnews.org/2017/11/300-travel-agents-media-set-disc over-new-shades-thailand-mega-fam-trip/.

- Travel Weekly, 2015. 08. 06, Available: https://www.travelweekly.com.au/ article/melbourne-airport-gets-a-stylish-facelift/.

- Uber Korea, 2019. 06. 16, Available: https://www.uber.com/ko-KR/newsr oom/uber-air-first-international-city-announcement/.

- Virgin Australia, 2014. 10. 28, Tourism Australia and Virgin Australia exp and global Marketing deal for 2015, Available: https://newsroom.virginau stralia.com/release/tourism-australia-and-virgin-australia-expand-global -marketing-deal-2015. 
- https://www.mlit.go.jp/koku/index.html

- https://www.brisbane.qld.gov.au/about-council/council-information-and -rates/council-businesses/brisbane-marketing

- https://www.jejuair.net

- https://www.kisf.org/html/dh/busi202

- https://travelbybit.com/

- https://mysterybreaks.virginaustralia.com/

- http://www.skybus.com.au/

- https://www.melbourne-airport.com/terminal-4.php

- https://womensjourney.tourismthailand.org

- https://www.grab.com/th/en/

- https://www.triptokorea.com:42200/korean/portal.php 


\section{ABSTRACT}

\section{A Research on Inbound Tourism Activation Using Regional Airports}

More than $90 \%$ of all foreign tourists visiting Korea enter the country through airports, and the importance of air transport is increasing in a sector of international tourism. However, there is a concern that the strategy for a hub of Incheon Airport will intensify the concentration of foreign tourists in the Seoul metropolitan area. In fact, the proportion of foreign tourists through Incheon Airport reaches about 70\%, and other regional airports, except Gimhae Airport and Jeju Airport, have a little role as entry gateways.

Until now, the international routes at regional airports have tended to be distributed mainly based on the overseas travel demand and preferred destinations of the Korean people. Most regional airports not only have insufficient information service for foreign tourists, but also have inconvenient public transportation that connects the airport to the city center or nearby tourist sites, therefore urgent improvement is required.

This study presented a total of nine policy tasks in order to strengthen the attraction of foreign tourists using regional airports. First of all, in order to create inbound passenger demand at regional airports, policy measures such as joint development of international routes, attraction of LCCs and foreign airlines, and expansion of demand for transit tourists are necessary. In order to improve inconvenience when using regional airports, policy measures such as foreign language information service, airport-linked transportation system, tax-free and shopping tourism satisfaction are proposed. In addition, in order to activate regional 
tourism by the linkage to the airport, it is necessary to develop international tourist attractions, make an airport as a regional landmark, and strengthen overseas tourism marketing.

In the future, cooperation policy between tourism and aviation sectors should be re-established in the direction of activating regional tourism, rather than simply focusing on attraction of foreign tourists visiting Korea. It is important to share roles and cooperate among various actors in the tourism and aviation sectors, and also to increase the synergy effect of the policy by the linkage to government plans and major projects.

In the region, it is necessary to build a tourism-aviation cooperation governance centered on the local government, and to establish policies and strategies which are suitable for the market and conditions of the airport. In the tourism sector, it is important to make tourism products with high added value by developing tourism attractions at international level and discovering themes and tourism contents that are distinct from other regions.

\section{Keywords}

Regional Airports, Foreign Tourist Information, Public Transport, Overseas Marketing 
지방공항을 활용한 지역관광 활성화 방안

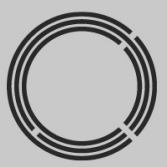

부록 



\section{【부록1】외국인 심층면접조사 설문지}

\section{〈지방공항을 활용한 지역관광 활성화 방안〉 연구를 위한 심층면접 조사}

\begin{tabular}{|l|l|l|l|}
\hline \multicolumn{4}{|c|}{ [ 응답자 정보 기입란 ] } \\
\hline$>$ 성명 & & $>$ 국적 & \\
\hline 성별 & & 출생년도 & \\
\hline 직업 & & > 연락처 & \\
\hline
\end{tabular}

* 조사 완료 시 작성해 주신 연락처로 답례품이 지급될 예정이니 정확하게 작성해 주시길 바랍니다,

* 조사 담당자 (주)리서치랩 조민희 연구원(02-559-2773)

\section{인터뷰 시행 목적}

[인터뷰 목적]

안녕하세요. 조사 전문기관 리서치랩입니다.

문화체육관광부 산하 한국문화관광연구원에서 수행 중인「지방공항을 활용한 지역관광 활성화 방안」연구의 일환으로, 지방공항 이용 경험이 있는 외국인 방문객들을 대상으로 지역관광 실태와 주요 개선사항 등에 관한 의견을 수렴하고, 향후 관련정책 수립의 기초자료로 활용하고자 요청드리게 되었습니다.

다음 각 질문에 대하여 귀하께서 평소 생각하시던 바를 편하게 말씀해 주시고, 답변 내용은 적극 검토하여 방한 외국인을 위한 지방공항 편의서비스 개선 및 지역관광 활성화를 위한 정책 방향 수립에 반영하도록 하겠 습니다.

Q1. 먼저 간단하게 자기 소개를 부탁드립니다.

- 이름, 국적, 나이, 직업 등

Q2. 귀하께서는 최근 3년간 한국을 몇 번 방문하셨나요?

- 방문 빈도, 1 회 체류기간, 마지막 방문 시점 등 추가 질문 
Q3. 귀하께서는 한국 방문 전 해외 현지에서 어떤 경로를 통해 한국 여행 정보를 얻으셨나요?

- 구체적인 경로(OO홈페이지 등), 해당 경로별 획득 정보, 경로별 이용 이유

- 방문 전 필요했던 정보, 필요한 정보 획득 여부, 부족했던 정보 등 정보획득에 어려움 확인

Q4. 귀하께서 한국을 방문하실 때 어떤 경로를 통하여 입국하시나요? 이용해보신 시설(공항, 항만 등)을 모두 말씀해주세요

- 입국 공항(항만), 최근 3년간 이용 공항(항만) 및 횟수 - 단순한 공항시설 방문이 아닌, 해외 출입국을 위한 관문으로써 이용 경험

Q5. 귀하께서 가장 최근에 김해공항을 방문·이용하신 것은 언제인가요?

- 구체적인 연도와 월(또는 시즌)을 말씀해주세요.

Q6. 귀하께서는 어떤 여행 목적으로 김해공항을 이용하셨나요?

- 휴가나 관광목적 여행, 비즈니스 업무상 출장, 해외 친지나 친구 방문 등

Q7. 귀하께서는 (1)단체패키지여행 또는 (2)개별여행(FIT) 중에 어떤 형태였나요?

- 여행사의 패키지상품(항공, 호텔, 투어 등) 이용 여부를 말씀해주세요.

- 해당 상품을 선택하신 이유는 무엇인가요? 
Q8. 사전 항공편 예약과 구매는 어떤 경로를 통해 하셨나요?

- 예) 항공사 홈페이지, 온라인 여행사(OTA), 여행사 대리점 등

- 해당 경로를 통해 구매하신 이유는 무엇인가요?

Q9. 귀하께서 최근 김해공항 입/출국시 이용하신 항공사는 어디입니까? (한국 방문시 출/입국 포함)

- 해당 항공사 선택 이유(국적기 이용, 저렴한 가격, 다양한 노선, 환승 편리 등)

- 타 항공사 이용 경험, 항공사별 장/단점 또는 차이점

Q10. 김해공항의 출·입국 절차는 시간이 어느 정도 걸렸나요?

- 평균 대기시간이 길고 짧음에 대한 개인 평가 의견을 말씀해주세요.

Q11. 김해공항에서 이용해 본 시설이나 서비스는 무엇인가요?

- 예) 관광안내데스크, 식당/카페, 면세점/쇼핑상점, 렌트카, 핸드폰 로밍, 환전 등

- 공항 시설 및 서비스에 대한 만족 수준, 만족 불만족 이유

- 공항 시설 이용 시 주변 도시나 지역의 관광지에 대해 정보를 얻을 수 있었는지 여부

Q12. 김해공항을 이용하는 외국인 관광객을 위해 개선 또는 추가되어야 할 점은 무엇인가요? - 예) 외국어 통역안내, 공항-도심간 셔틀버스, 면세점 쇼핑 등 구체적으로 제안해주세요 
Q13. 김해공항에서 주변 관광지로 여행을 간다면, 가장 필요한 정보는 무엇인가요?

- 예) 대중교통, 추천 관광지, 호텔 등 숙박시설, 먹거리나 식당, 축제 이벤트 등

- 여행 정보 획득에 어려운 점, 좋았던 점, 더 필요한 정보 등 추가 질문

Q14. 김해공항에서 도심이나 주변 관광지로의 이동을 위해 어떤 교통수단을 이용하셨나요?

- 예) 리무진버스, 기차, 지하철, 택시, 자가용, 렌트카 등 구체적으로 말씀해주세요.

- 이용한 교통수단에 대한 만족 수준, 만족/불만족 이유

Q15. 김해공항의 접근성 및 연계교통 관련하여 개선 또는 추가되어야 할 점은 무엇인가요?

- 예) 운행 스케줄, 비싼 요금, 주차장 부족, 렌트카·공유차량 부재 등 구체적으로 말씀해주세요.

Q16. 귀하께서는 김해공항 주변 도시나 지역의 어떤 관광지를 방문해보셨나요?

- 예) 지자체명(시·군), 관광지, 방문장소 등을 구체적으로 말씀해주세요.

Q17. 김해공항 인근 관광지를 방문하여 여행할 때 가장 좋았던 점은 무엇이었나요?

- 예) 자연경관, 문화체험, 음식, 호텔·숙박시설 등 구체적으로 설명해주세요. 
Q18. 반대로 김해공항 인근 관광지를 방문하여 여행할 때 가장 불편했던 점은 무엇이었나요?

- 예) 교통수단, 언어소통, 호텔·숙박시설 부족 등 구체적으로 설명해주세요.

Q19. 해외여행을 위해 김해공항을 통해 출국할 경우, 예상되는 가장 큰 어려움은 무엇인가요?

- 예) 공항까지 이동거리·시간, 출입국 절차, 터미널 혼잡 등 구체적으로 설명해주세요.

Q20. 국내 타 공항과 비교할 때, 김해공항의 (1)장점과 (2)단점은 무엇인가요?

- 국내 타 공항 이용 경험 질문 후 인천공항 이용 경험이 있는 경우 인천공항 비교, 그 외 다른공항 이용자는 해당 공항이 어디인지 확인하고 질문

- 국내 이용 공항이 없을 경우 해외 공항과 비교 가능(비교 공항이 어디인지 반드시 작성)

- 예) 항공노선, 교통접근, 면세점, 식음료 시설 등 구체적으로 설명해주세요.

Q21. 김해공항을 활용하여 방한 외국인 관광객들을 지방으로 유치하기 위해 가장 필요한 정책은 무엇이라고 생각하시나요?

- 예) 지방공항 입국 외국인 비자 면제, 무료 환승관광 프로그램 등 구체적으로 설명해주세요. 


\section{【부록2】 태국의 주요 공항별 특성}

태국의 주요 공항은 태국공항공사(AOT)가 관할하는 도시거점형 공항으로 수완 나폼 공항(BKK)과 돈무앙 공항 $(\mathrm{DMK})$ 이 있으며, 지역연계형 공항으로는 태국 북부 내륙에 위치한 치앙마이 공항(CNX), 치앙라이 공항(CEI), 남부 해변에 위치한 푸켓 공항(HKT), 핫야이 공항(HDY) 등이 있다. 이들 공항의 특징과 주변 지역의 관광자원 현황을 정리하면 아래 표와 같다.

\section{가. 수완나폼 공항(BKK): 도심거점형, 태국 방콕 위치}

\begin{tabular}{|c|c|c|}
\hline \multirow{3}{*}{$\begin{array}{l}\text { 설립 } \\
\text { 연도 } \\
\text { 및 } \\
\text { 위치 }\end{array}$} & 설립연도 & 2006년 9월 15일 설립 \\
\hline & $\begin{array}{l}\text { 소재지 } \\
\text { (주소) }\end{array}$ & $\begin{array}{l}999 \text { Moo } 1 \text { Bangna - Trad Road Km } 15 \text { Rachathewa, Bang Phli Samut } \\
\text { Prakan 10540, Thailand }\end{array}$ \\
\hline & 접근성 & 방콕에서 동쪽으로 $30 \mathrm{~km}$ (택시, 공항버스, 노선버스 이용 가능) \\
\hline \multicolumn{2}{|c|}{$\begin{array}{l}\text { 운항하고 있는 } \\
\text { 항공사 현황 }\end{array}$} & $\begin{array}{l}\text { - 한국(대한항공, 아시아나항공, 제주항공, 이스타항공, 진에어, 티웨이항공) } \\
\text { - 태국(타이항공, 방콕 항공, 타이 스마일 항공, 타이 비엣젯항공) } \\
\text { - 일본(일본항공, 전일본공수, 피치항공) } \\
\text { - 중국(중국국제항공, 중국동방항공, 중국남방항공, 등) } \\
\text { - 홍콩(홍콩항공, 홍콩 익스프레스 항공, 캐세이퍼시픽항공) } \\
\text { - 프랑스(에어프랑스, 에어오스트랄) } \\
\text { - 러시아(에어로플로트, 우랄항공, S7 항공) } \\
\text { - 독일(루프트한자, 유로윙스) }\end{array}$ \\
\hline \multicolumn{2}{|c|}{$\begin{array}{l}\text { 일일(연간) 최대 } \\
\text { 여객처리 수 }\end{array}$} & $\begin{array}{l}\text { - 1일 최대 여객 처리 수: 연간 여객 처리 수/365= 약 173,641명 } \\
\text { - 연간 최대 여객 처리 수: } 63,379,077 \text { 명(2018년 AOT 기준) }\end{array}$ \\
\hline \multirow[t]{2}{*}{$\begin{array}{l}\text { 공항의 } \\
\text { 장·단점 }\end{array}$} & 장점 & $\begin{array}{l}\text { - Airport Rail Link이라는 도시철도시스템을 통해 수완나폼 공항과 방콕시 사이에 } \\
\text { 편리하게 움직일 수 있음 } \\
\text { - 국제선 및 국내선을 동시에 이용할 수 있음 } \\
\text { - 노보텔 방콕 수완나폼 에어포트(Novotel Bangkok Suvarnabhumi Airport)에서 } \\
\text { 걸어서 } 5 \text { 분 거리 } \\
\text { - 동남아시아에서 가장 큰 국제공항 중 하나이며, 태국항공(타이항공, 방콕항공, 타이 } \\
\text { 비엣젯 항공 등)의 허브공항임 } \\
\text { - 주요 여객터미널은 시간당 } 76 \text { 회의 비행운항을 처리할 수 있는 능력을 갖고 있음(세 } \\
\text { 계에서 4번째로 큰 공항 터미널) } \\
\text { - 수완나폼-돈무앙 연결 버스(Bangkok Mass Transit Authority(BMTA))가 매일 } \\
\text { 새벽 } 5 \text { 시부터 밤 } 12 \text { 시까지 무료운행 }\end{array}$ \\
\hline & 단점 & $\begin{array}{l}\text { - 세계에서 17번째로 붐비는 공항, 아시아에서 11번째로 붐비는 공항, 그리고 태국에 } \\
\text { 서 가장 붐비는 공항임. 공항이 너무 넓고 바쁘기 때문에 복잡한 상태에서 승객들이 } \\
\text { 일 처리(위탁 수하물, 길 찾기, 발권 등)하는데 어려움을 겪을 수 있음 } \\
\text { - 여객 터미널 건물은 하나이므로 혼잡으로 인해 비행 출발 시간이 지연될 수 있음 }\end{array}$ \\
\hline
\end{tabular}




\begin{tabular}{|c|c|c|}
\hline \multirow[t]{2}{*}{$\begin{array}{l}\text { 공항 } \\
\text { 주변 } \\
\text { 관광 } \\
\text { 자원 }\end{array}$} & 유명 관광지 & $\begin{array}{l}\text { - 박물관: 무앙보란(Ancient City) 야외 박물관, 에라완 뮤지엄(Erawan Museum) } \\
\text { - 쇼핑거리: 센트럴 방나(Central Bangna), 메가방나(Mega Bangna), 담는사두악 } \\
\text { 수상시장(Damnoen Saduak Floating Market), 씨암 파라곤(Siam Paragon } \\
\text { Shopping Complex) } \\
\text { - 왓포 사원(Wat Pho Temple) } \\
\text { - 왕궁(Grand Palace) } \\
\text { - 카오산 로드(Khao San Road) }\end{array}$ \\
\hline & 관광 상품 & $\begin{array}{l}\text { - 아시아티크 더 리버프론트에서 칼립소 카바레 쇼(Calypso Cabaret Show) 관람 } \\
\text { - Dream World Bangkok 놀이공원 } \\
\text { - 씨 라이프 오션 월드(SEA LIFE Bangkok Ocean World) 해양 생물 구경 } \\
\text { - 방콕 시암니라밋 쇼(Bangkok Siam Niramit Show) 관람 }\end{array}$ \\
\hline \multicolumn{2}{|c|}{ 본 공항의 특징 } & 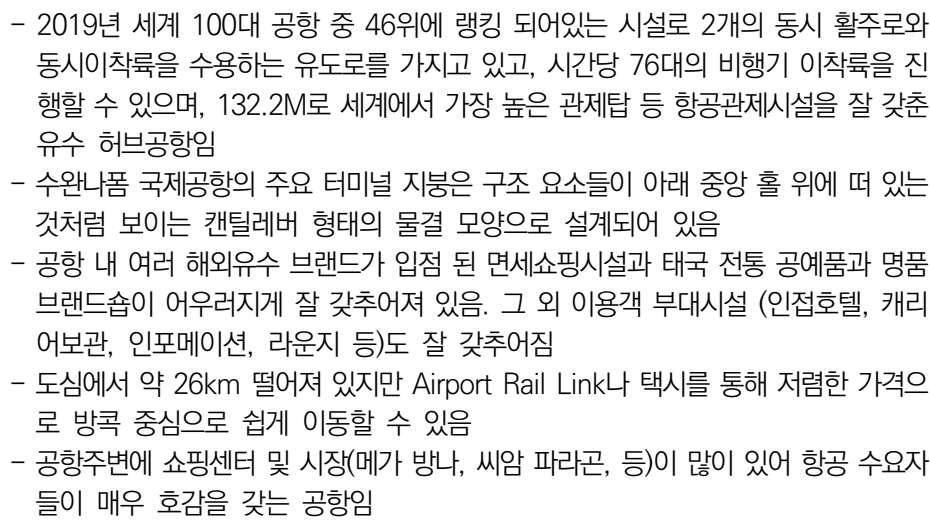 \\
\hline
\end{tabular}




\section{나. 돈무앙 공항(DMK): 도심거점형, 태국 방콕 위치}

\begin{tabular}{|c|c|c|}
\hline \multirow{3}{*}{$\begin{array}{l}\text { 설립 } \\
\text { 연도 } \\
\text { 및 } \\
\text { 위치 }\end{array}$} & 설립연도 & 1914년 3월 27일 설립 \\
\hline & $\begin{array}{l}\text { 소재지 } \\
\text { (주소) }\end{array}$ & $\begin{array}{l}222 \text { Vibhavadi Rangsit Road, Sanambin Don Mueang, Bangkok 10210, } \\
\text { Thailand }\end{array}$ \\
\hline & 접근성 & $\begin{array}{l}\text { 방콕 도심에서 북쪽으로 } 22 \mathrm{~km} \text { (고속도로와 일반 디젤열차 및 공항 특급열차로 구분 } \\
\text { 되는 철도 이용 기능) }\end{array}$ \\
\hline \multicolumn{2}{|c|}{$\begin{array}{l}\text { 운항하고 있는 } \\
\text { 항공사 현황 }\end{array}$} & $\begin{array}{l}\text { - 태국(타이 에어아시아, 타이 에어아시아 X, 녹에어, 녹스쿠트항공, 타이 라이온에어) } \\
\text { - 말레이시아(에어아시아, 말린도에어) } \\
\text { - 인도네시아(인도네시아 에어아시아, 바틱에어) } \\
\text { - 몰디브 공화국(몰디브항공) } \\
\text { - 대만(타이거에어 타이완) } \\
\text { - 싱가포르(스쿠트항공) } \\
\text { - 필리핀(필리핀 에어아시아) }\end{array}$ \\
\hline \multicolumn{2}{|c|}{$\begin{array}{l}\text { 일일(연간) 최대 } \\
\text { 여객처리 수 }\end{array}$} & $\begin{array}{l}\text { - 1일 최대 여객 처리 수: 연간 여객 처리 수/365= 약 } 111,666 \text { 명 } \\
\text { - 연간 최대 여객 처리 수: } 40,758,148 \text { 명(2018년 AOT 기준) }\end{array}$ \\
\hline \multirow{2}{*}{$\begin{array}{l}\text { 공항의 } \\
\text { 장·단점 }\end{array}$} & 장점 & $\begin{array}{l}\text { - 방콕 중심에 있는 민주기념탑(Democracy Monument)에서 가까움(민주기념탑 } \\
\text { 북쪽으로 약 } 23 k m) \text { 국제선 및 국내선을 동시에 이용할 수 있음 } \\
\text { - 많은 저비용 항공사(AirAsia, Scoot, Nok Air 등)를 운용함 } \\
\text { - 수완나폼-돈무앙 연결 버스 Bangkok Mass Transit Authority(BMTA)가 매일 } \\
\text { 새벽 } 5 \text { 시부터 밤 } 12 \text { 시까지 무료운행 }\end{array}$ \\
\hline & 단점 & $\begin{array}{l}\text { - 말린도 항공을 제외하고 운영하는 FSC 항공사가 없음 } \\
\text { - 수완나폼 공항에 비해 규모가 많이 작음 } \\
\text { - 공항이 좁고 일손이 부족하기 때문에 승객들은 줄을 서서 오랫동안 기다리는 경우 } \\
\quad \text { 가 많음 }\end{array}$ \\
\hline \multirow{2}{*}{$\begin{array}{l}\text { 공항 } \\
\text { 주변 } \\
\text { 관광 } \\
\text { 자원 }\end{array}$} & 유명 관광지 & $\begin{array}{l}\text { - 태국 방콕의 역사 관광지: 왕궁(Grand Palace), 민주기념탑, 왓 포(Wat Pho), 왓 } \\
\text { 아룬(Wat Arun), 왓수탓(Wat Suthat) 등 } \\
\text { - 짐 톰프슨의 집(Jim Thompson's House) } \\
\text { - 담는사두악 수상시장(Damnoen Saduak Floating Market) } \\
\text { - 짜오 프라야 강(Chao Phraya River) } \\
\text { - 왓 뜨라이밋(Wat Traimit) }\end{array}$ \\
\hline & 관광 상품 & $\begin{array}{l}\text { - 짜오 프라야 강 유람선 타기, 아시아티크(Asiatique) 야시장 쇼핑 } \\
\text { - 차이나타운의 보트 및 사이클링 투어 } \\
\text { - 카오산 로드(Khao San Road)에서만 경험할 수 있는 값싼 숙박비, 음식, 음료수, } \\
\text { 활기찬 분위기, 느긋한 대접 등 } \\
\text { - 태국에서 가장 큰 시장인 짜뚜짝 시장(Chatuchak Market)에서 쇼핑 }\end{array}$ \\
\hline \multicolumn{2}{|c|}{ 본 공항의 특징 } & $\begin{array}{l}\text { - 방콕의 또 다른 국제공항 수완나폼 공항에 비해 규모가 많이 작기 때문에 공항에 } \\
\text { 사람들이 적고 덜 복잡함 } \\
\text { - 주로 LCC 항공편을 운영하고 있으며 운임이 저렴한 국내선 항공편이 휠씬 많음 } \\
\text { - 아시아 및 타이항공의 허브공항으로 수완나폼 공항의 운영비가 높아 경제성 문제가 } \\
\text { 지적되자 2007년 다시 운영이 재개됨. 국제선 및 치앙마이 등 태국 북부와 내륙을 } \\
\text { 이어주는 공항임 }\end{array}$ \\
\hline
\end{tabular}




\section{다. 치앙마이 공항(CNX): 지역연계형, 태국 북부 위치}

\begin{tabular}{|c|c|c|}
\hline \multirow{3}{*}{$\begin{array}{l}\text { 설립 } \\
\text { 연도 } \\
\text { 및 } \\
\text { 위치 }\end{array}$} & 설립연도 & 1921년 설립(처음에는 Suthep Airport로 설립됨) \\
\hline & $\begin{array}{l}\text { 소재지 } \\
\text { (주소) }\end{array}$ & $\begin{array}{l}60 \text { Mahidol Road, Sutep Subdistrict, Muang District, Chiang Mai Province } \\
\text { 50200, Thailand }\end{array}$ \\
\hline & 접근성 & $\begin{array}{l}\text { 치앙마이 시내에서 남서쪽으로 } 4 \mathrm{~km} \text { (리무진, 버스, RTC 택시, 호텔 셔틀, 렌터카 이 } \\
\text { 용 가능) }\end{array}$ \\
\hline \multicolumn{2}{|c|}{$\begin{array}{l}\text { 운항하고 있는 } \\
\text { 항공사 현황 }\end{array}$} & $\begin{array}{l}\text { - 한국(대한항공, 아시아나항공, 티웨이항공, 제주항공) } \\
\text { - 중국(중국국제항공, 중국남방항공, 중국동방항공, 준야오항공 등) } \\
\text { - 홍콩ㅋ캐세이 드래곤 항공, 홍콩 익스프레스 항공) } \\
\text { - 중화민국(에바항공, 중화항공, 스타룩스 항공) } \\
\text { - 태국(녹에어, 타이 에어아시아, 타이 라이온에어, 타이 스마일 항공, 칸 에어, 타이 } \\
\quad \text { 항공, 방콕 항공) } \\
\text { - 말레이시아(에어아시아) } \\
\text { - 싱가모르(스쿠트항공) }\end{array}$ \\
\hline \multicolumn{2}{|c|}{$\begin{array}{l}\text { 일일(연간) 최대 } \\
\text { 여객처리 수 }\end{array}$} & $\begin{array}{l}\text { - 1일 최대 여객 처리 수: 연간 여객 처리 수/365= 약 } 30,109 \text { 명 } \\
\text { - 연간 최대 여객 처리 수: } 10,989,869 \text { 명(2018년 AOT 기준) }\end{array}$ \\
\hline \multirow[t]{2}{*}{$\begin{array}{l}\text { 공항의 } \\
\text { 장·단점 }\end{array}$} & 장점 & $\begin{array}{l}\text { - 태국 북부의 주요 관문 기능을 하는 지방공항임 } \\
\text { - 치앙마이 도시 중심에서 매우 가까워서(4km 거리) 교통이 편리한 입지조건을 갖춤 } \\
\text { - 2014년 업그레이드: 대형 항공기 주기장 확장, } 24 \text { 시간 운영(2014년 4월 유효), } \\
\text { 국제선 입국장 및 국내선 출국장 확대 } \\
\text { - 국제선 및 국내선을 동시에 이용할 수 있음. 두 개의 연결된 터미널이 있으며, 국제 } \\
\text { 선과 국내선으로 나눠짐 } \\
\text { - 규모가 작기 때문에 승객들은 공항 내 갈 길을 쉽게 찾을 수 있음 }\end{array}$ \\
\hline & 단점 & $\begin{array}{l}\text { - 규모가 작고 활주로가 하나이므로 처리되는 항공편의 수에 제한이 있음 } \\
\text { - 도시 근처에 있기 때문에 공항을 드나드는 비행기들이 소음을 유발함 } \\
\text { - 공항과 연결된 호텔이 없음(공항에서 제일 가까운 호텔은 } 0.7 \mathrm{~km} \text { 거리) }\end{array}$ \\
\hline \multirow{2}{*}{$\begin{array}{l}\text { 공항 } \\
\text { 주변 } \\
\text { 관광 } \\
\text { 자원 }\end{array}$} & 유명 관광지 & $\begin{array}{l}\text { - 왓 프라탓 도이수텝(Wat Phra That Doi Suthep) } \\
\text { - 왓 체디루앙(Wat Chedi Luang) } \\
\text { - 왓 프라싱(Wat Phra Singh) } \\
\text { - 도이 수텝(Doi Suthep) } \\
\text { - 도이스텝 푸이 국립공원(Doi Suthep Pui National Park) }\end{array}$ \\
\hline & 관광 상품 & $\begin{array}{l}\text { - 치앙마이 나이트 바자 / 야시장(Chiang Mai Night Bazaar) 쇼핑 및 길거리 음식 체험 } \\
\text { - 치앙마이 나이트 사파리(Chiang Mai Night Safari) 투어 } \\
\text { - 치앙마이 선데이 마켓(Sunday Walking Street Market)의 음식, 주점, 도로변 } \\
\text { 마사지 구역 등 } \\
\text { - 치앙마이 님만해민 거리의 유명한 식당, 영화관, 쇼핑몰 등 }\end{array}$ \\
\hline \multicolumn{2}{|c|}{ 본 공항의 특징 } & $\begin{array}{l}\text { - 치앙마이 공항은 국제선, 국내선을 모두 이용할 수 있는 공항으로 태국 북부지역에 } \\
\text { 서 효율적인 이동을 할 수 있는 장점을 가진 공항임 } \\
\text { - 태국의 다른 공항에 비해 시내에서 가까움 } \\
\text { - 태국 북·서부 지역 관광지 이동이 가까워 관광객의 이동에 효율성이 높음 } \\
\text { - 수완나폼 공항과 돈무앙 공항에 비해 규모가 작고 건물 구조가 간단하며 처음 여행 } \\
\text { 하는 승객들에게 편안하고 안락함을 줌 } \\
\text { - 태국의 북부는 4월 } 10 \text { 월 날씨가 좋고 성수기이며, 태국 북부의 관문으로서 치앙마 } \\
\text { 이 공항의 항공수요가 증가함 }\end{array}$ \\
\hline
\end{tabular}




\section{라. 치앙라이 공항(CEI): 지역연계형, 태국 북부 위치}

\begin{tabular}{|c|c|c|}
\hline \multirow{3}{*}{$\begin{array}{l}\text { 설립 } \\
\text { 연도 } \\
\text { 및 } \\
\text { 위치 }\end{array}$} & 설립연도 & 1992년 설립 \\
\hline & $\begin{array}{l}\text { 소재지 } \\
\text { (주소) }\end{array}$ & 태국 치앙라이 주 치앙라이(404, Ban Du, Amphoe, 치앙라이 57000 태국) \\
\hline & 접근성 & $\begin{array}{l}\text { 치앙라이 주 시내 중심에서 약 } 8 \mathrm{~km} \text { (리무진, 렌터카, 택시로 약 15 20분, 2018년 } \\
\text { 부터 공항버스 이용 가능) }\end{array}$ \\
\hline \multicolumn{2}{|c|}{$\begin{array}{l}\text { 운항하고 있는 } \\
\text { 항공사 현황 }\end{array}$} & $\begin{array}{l}\text { - 태국(방콕 항공, 타이 스마일 항공, 타이 비엣젯에어. 타이 에어아시아, 녹 에어, } \\
\text { 타이 라이온에어) } \\
\text { - 중국(중국남방항공, 중국동방항공, 하이난항공, 쓰촨항공) } \\
\text { - 홍콩(홍콩 익스프레스 항공)까지 총 } 11 \text { 개 항공사 운항 }\end{array}$ \\
\hline \multicolumn{2}{|c|}{$\begin{array}{l}\text { 일일(연간)최대 } \\
\text { 여객처리 수 }\end{array}$} & $\begin{array}{l}\text { - 1일 최대 여객 처리 수: 약 7,830여명 } \\
\text { - 연간 최대 여객 처리 수: } 300 \text { 만 명(2019년 기준) }\end{array}$ \\
\hline \multirow[t]{2}{*}{$\begin{array}{l}\text { 공항의 } \\
\text { 장·단점 }\end{array}$} & 장점 & $\begin{array}{l}\text { - 2030년 완공을 목표로 추가 유도로와 상점 확장 계획을 추진 중임 } \\
\text { - 공항 내부에 관광객을 위한 치앙라이 지역 특산품과 수공예품 등 기념품 판매 } \\
\text { - 국제선과 국내선 체크인 공간이 동일하여 혼란 없이 편리하게 이용할 수 있음 } \\
\text { - 시원한 야외산책로(Samui park avenue)를 조성하여 } 12 \text { 개의 상점을 제공하고 } \\
\quad \text { 콘서트와 미술 전시회를 개최함 }\end{array}$ \\
\hline & 단점 & $\begin{array}{l}\text { - 공항의 규모가 다소 작기에 수요가 많은 성수기 시즌에는 공항에 인파가 몰리면 } \\
\text { 서 다소 번잡할 수 있고 대기 장소가 조금 부족함 }\end{array}$ \\
\hline \multirow{2}{*}{$\begin{array}{l}\text { 공항 } \\
\text { 주변 } \\
\text { 관광 } \\
\text { 자원 }\end{array}$} & 유명 관광지 & $\begin{array}{l}\text { - 추이퐁 차(Choui Fong Tea) 농장 } \\
\text { - 왓 롱 쿤(War Rong Khun), 왓 롱 수아 텐(Wat Rong Suea Ten) 사원 } \\
\text { - 골든 트라이앵글: 메콩 강을 경계로 태국, 미얀마, 라오스 3개국의 국경이 만나는 } \\
\text { 꼭지점인 치앙쌘(chiang saen)에 있으며 차로 약 2시간 소요 } \\
\text { - 왓 프라 깨오 사원(에메랄드 사원) } \\
\text { - 도이 뚱 로얄 빌라(Doi Tung Royal Villa): 태국의 알프스라고 불림 } \\
\text { - 웁 캄 박물관(Oub Kham Museum) } \\
\text { - 치앙라이 시계탑(Golden Clock Tower) } \\
\text { - 싱하 파크(Singha Park): 대규모 공원과 작은 동물원, 짚 라인 체험 }\end{array}$ \\
\hline & 관광 상품 & $\begin{array}{l}\text { - 치앙라이 아트 브리(미술관) 갤러리와 아트숍 구경 및 현지음식 체험 } \\
\text { - 치앙라이 나이트 바자(야시장) 푸드 트럭과 주변 공연, 수공예품 구매 } \\
\text { - 푸치파(Phu Chi Fa)에서 일출 구경 } \\
\text { - 고산족 마을(Union of Hill Tribe Villages) 특산품 구매와 공연 관람 } \\
\text { - 워터포트 밸리, 해피시티, 산티부리 컨트리클럽에서 골프 } \\
\text { - 센트럴 플라자(Central Plaza) 로빈슨 백화점 운영 쇼핑센터에서 쇼핑 } \\
\text { - Saturday Market \& Sunday Market의 야시장 구경과 먹거리 체험 }\end{array}$ \\
\hline \multicolumn{2}{|c|}{ 본 공항의 특징 } & $\begin{array}{l}\text { - 자연환경과 소수민족들의 전통, 특유 여유로운 라이프를 추구하는 관광객에게 새 } \\
\text { 로운 여행지로 손꼽히며 ‘한 달 살기' 유행으로 수요가 증가하고 있는 공항 } \\
\text { - 치앙라이 시티 도심과 } 15 \text { 분 거리상으로 가까이 있기 때문에 공항이 마을로 둘러 } \\
\text { 쌓여있지는 않지만 항행 시 작은 소음이 발생되는 공항임 }\end{array}$ \\
\hline
\end{tabular}




\section{마. 푸켓 공항(HKT): 지역연계형, 태국 남부 해변 위치}

\begin{tabular}{|c|c|c|}
\hline \multirow{3}{*}{$\begin{array}{l}\text { 설립 } \\
\text { 연도 } \\
\text { 및 } \\
\text { 위치 }\end{array}$} & 설립연도 & 1947년 설립 \\
\hline & $\begin{array}{l}\text { 소재지 } \\
\text { (주소) }\end{array}$ & Mai Khao, Thalang District, Phuket 83110 \\
\hline & 접근성 & $\begin{array}{l}\text { 푸켓공항에서 푸켓 도심까지 대략 } 32 \mathrm{~km} \text { 임(이동수단은 공항셔틀버스, 택시, 기타 자 } \\
\text { 동차로 이용 가능함) }\end{array}$ \\
\hline \multicolumn{2}{|c|}{$\begin{array}{l}\text { 운항하고 있는 } \\
\text { 항공사 현황 }\end{array}$} & $\begin{array}{l}\text { - 한국(대한항공, 아시아나항공, 진에어) } \\
\text { - 중국(중국국제항공, 중국남방항공, 중국동방항공 등) } \\
\text { - 태국(녹에어, 타이 에어아시아, 타이항공 등) } \\
\text { - 호주(제트스타항공) } \\
\text { - 싱가포르(싱가포르항공, 스쿠트항공, 실크에어, 제트스타 아시아항공 등) }\end{array}$ \\
\hline \multicolumn{2}{|c|}{$\begin{array}{l}\text { 일일(연간) 최대 } \\
\text { 여객처리 수 }\end{array}$} & $\begin{array}{l}\text { - 1일 최대 여객 처리 수: } 27,398 \text { 명 } \\
\text { - 연간 최대 여객 처리 수: } 10,100,000 \text { 명 (2019년 기준) }\end{array}$ \\
\hline \multirow{2}{*}{$\begin{array}{l}\text { 공항의 } \\
\text { 장·단점 }\end{array}$} & 장점 & $\begin{array}{l}\text { - 푸켓 공항은 푸켓 인근 관광지를 가기 위해 가장 중심이 되는 공항임 } \\
\text { - 공항셔를버스를 이용해서 푸켓 도심지로 갈 수 있어 접근성이 편리함 } \\
\text { - 공항에 여러 개의 기념품점과 면세점, 식당 등 편의시설이 갖추어져 있음 } \\
\text { - 태국에서 화물을 제외한 여객수가 2번째로 많은 국제공항으로 공항 내 시설들이 } \\
\text { 잘 갖추어져 있음 }\end{array}$ \\
\hline & 단점 & $\begin{array}{l}\text { - 타 지역으로 가는 대중교통편이나, 푸켓 도심지까지 가는 대중교통 수단이 많지 } \\
\text { 않음 } \\
\text { - 푸켓에도 미터 택시가 있지만, 아직 그 수가 많지 않아 이용하는 데 불편한 점이 } \\
\text { 있음 } \\
\text { - 공항에서 호텔로 가는 무료 공항 셔틀버스가 없고, 요금 또한 비쌈 }\end{array}$ \\
\hline \multirow{2}{*}{$\begin{array}{l}\text { 공항 } \\
\text { 주변 } \\
\text { 관광 } \\
\text { 자원 }\end{array}$} & 유명 관광지 & $\begin{array}{l}\text { - 푸켓 피피섬 } \\
\text { - 푸켓 카이섬 } \\
\text { - 푸켓 왓찰롱 사원 }\end{array}$ \\
\hline & 관광 상품 & $\begin{array}{l}\text { - 푸켓 올드타운 야시장에서 전통 수공예품 구경 및 먹거리 체험 } \\
\text { - 푸켓 노이섬 바다에서 스쿠버 다이빙 체험 } \\
\text { - 푸켓 아프로디테쇼 관람 등 }\end{array}$ \\
\hline \multicolumn{2}{|c|}{ 본 공항의 특징 } & $\begin{array}{l}\text { - 태국에서 2번째로 여행객들이 가장 많이 오는 공항인데 공항 내 여러 가지의 편의 } \\
\text { 시설은 갖추어져 있지만 공항에서 이용하는 게 불편함 } \\
\text { - 공항에서 호텔로 가는 무료 공항 셔틀 버스가 아직 없음 }\end{array}$ \\
\hline
\end{tabular}




\section{바. 핫야이 공항(HDY): 지역연계형, 태국 남부 해변 위치}

\begin{tabular}{|c|c|c|}
\hline \multirow{3}{*}{$\begin{array}{l}\text { 설립 } \\
\text { 연도 } \\
\text { 및 } \\
\text { 위치 }\end{array}$} & 설립연도 & 1971년 설립 \\
\hline & $\begin{array}{l}\text { 소재지 } \\
\text { (주소) }\end{array}$ & 399 Khlong La, Khlong Hoi Khong District, Songkhla \\
\hline & 접근성 & $\begin{array}{l}\text { 핫야이 공항에서 핫야이 도심지역까지 대략 } 15 \mathrm{~km} \text { 로 가까운 편에 속함(이동수단은 } \\
\text { 공항셔틀버스, 택시, 기타 자동차로 이용 가능함) }\end{array}$ \\
\hline \multicolumn{2}{|c|}{$\begin{array}{l}\text { 운항하고 있는 } \\
\text { 항공사 현황 }\end{array}$} & $\begin{array}{l}\text { - 푸켓(방콕 항공), 방콕(타이 에어아시아, 타이 라이온에어, 타이 스마일 항공, 녹에 } \\
\text { 어), 쿤밍(쿤밍 항공), 싱가포르(스쿠트항공) }\end{array}$ \\
\hline \multicolumn{2}{|c|}{$\begin{array}{l}\text { 일일(연간) 최대 } \\
\text { 여객처리 수 }\end{array}$} & $\begin{array}{l}\text { - 1일 최대 여객 처리 수: } 4,110 \text { 명 } \\
\text { - 연간 최대 여객 처리 수: } 3,000,000 \text { 명 (2019년 기준) }\end{array}$ \\
\hline \multirow[t]{2}{*}{$\begin{array}{l}\text { 공항의 } \\
\text { 장·단점 }\end{array}$} & 장점 & $\begin{array}{l}\text { - 핫야이 공항은 태국의 가장 끝자락에 위치한 공항이며, 말레이시아 국경과 가장 } \\
\text { 가까운 공항임 } \\
\text { - 핫야이 공항에서 핫야이 도심지역까지 차량으로 대략 } 15 \mathrm{~km} \text { 정도로 도심지역까지 } \\
\text { 접근이 편리함 } \\
\text { - 공항 내에서 핫야이 도심지로 연결하는 셔틀버스가 있어 이동이 편리함 }\end{array}$ \\
\hline & 단점 & $\begin{array}{l}\text { - 핫야이 이외에 다른 지역까지는 교통편이 좋지 않고, 육로 이동시간이 매우 길다 } \\
\text { 는 단점이 있음 } \\
\text { - 핫야이 공항은 태국의 끝자락에 위치한 만큼 숙소나 인근 식당, 상점가 등이 부족함 }\end{array}$ \\
\hline \multirow{2}{*}{$\begin{array}{l}\text { 공항 } \\
\text { 주변 } \\
\text { 관광 } \\
\text { 자원 }\end{array}$} & 유명 관광지 & $\begin{array}{l}\text { - 핫야이 벼룩시장 \& 재래시장 } \\
\text { - 핫야이 공원 정상의 불상 } \\
\text { - 핫야이 Ton nga chang 폭포 }\end{array}$ \\
\hline & 관광 상품 & $\begin{array}{l}\text { - 핫야이 클롱해 수산시장에서 핫야이 전통 수산물 요리 체험 } \\
\text { - 핫야이 큰부처가 있는 Municipality park에서 케이블카 탑승 } \\
\text { - 핫야이 Lee garden plaza에서 핫야이 꿍팟퐁커리 체험 }\end{array}$ \\
\hline \multicolumn{2}{|c|}{ 본 공항의 특징 } & $\begin{array}{l}\text { - 핫야이 국제공항은 핫야이 도심지역까지는 교통이 편리하지만, 다른 지역으로 가 } \\
\text { 는 교통은 불편하다는 단점이 있음 } \\
\text { - 핫야이 국제공항에서 도심 이외 지역으로 가고자 할 때는 사전에 교통편을 충분히 } \\
\text { 알아보고 이동을 해야 함 } \\
\text { - 핫야이 국제공항은 설립연도가 오래되고 실내 보수공사를 하지 않아서 공항 내 } \\
\quad \text { 시설이 매우 열악함 }\end{array}$ \\
\hline
\end{tabular}




\section{【부록3】 호주의 주요 공항별 특성}

호주의 15 개 국제공항 중에 국제여객을 $99 \%$ 이상 수송하는 10 개의 주요 공항 가 운데, 도심거점형 공항으로 대표되는 시드니 공항과 멜버른 공항이 운영되고 있으 며, 지역연계형 공항으로는 동부지역을 대표하는 브리즈번 공항, 서부지역을 대표 하는 퍼스 공항과 그 외 6 개의 공항이 운영되고 있다. 그러나 지역연계형 공항 중 캔버라 공항은 2016년부터 국제선 여객을 수송하기 시작하였으며, 이에 반해 하버 공항은 1999 년까지는 매우 활발하게 국제선 여객을 수송하였으나, 이후 현재까지 단항이 되어 국제공항으로서 그 기능을 다하지 못하고 있다.

\section{가. 시드니 공항(SYD): 도심거점형, 시드니지역 위치}

\begin{tabular}{|c|c|c|}
\hline \multirow{3}{*}{$\begin{array}{l}\text { 설립 } \\
\text { 연도 } \\
\text { 및 } \\
\text { 위치 }\end{array}$} & 설립연도 & 1920년 01월 20일 설립 \\
\hline & $\begin{array}{l}\text { 소재지 } \\
\text { (주소) }\end{array}$ & Airport Central, 241 O 'Riordan Street, Mascot NSW 2020, Australia \\
\hline & 접근성 & $\begin{array}{l}\text { 시드니 도심으로부터 남쪽으로 약 8 9km } \\
\text { 교통수단 : 공항철도, 한인 픽업, 공항택시, 버스, 우버 이용 가능 }\end{array}$ \\
\hline \multicolumn{2}{|c|}{$\begin{array}{l}\text { 운한하고 있는 } \\
\text { 항공사 현황 }\end{array}$} & $\begin{array}{l}\text { 국내선: } 10 \text { 개 노선 } \\
\text { 국제선: 한국(2), 중국(6), 호주(3), 홍콩(1), 일본(1), 타이완(1), 말레이시아(2), 베 } \\
\text { 트남(1), 싱가포르(2), 인도네시아(1), 방콕(1), 필리핀(1), 인도(1), 아랍에 } \\
\text { 미레이트(2), 모리셔스(1), 영국(1), 미국(4), 캐나다(1), 칠레(1), 뉴질랜드 } \\
\text { (1), 누벨칼레도니(1), 바누아투(1), 파푸아뉴기니(1), 피지(1) }\end{array}$ \\
\hline \multicolumn{2}{|c|}{$\begin{array}{l}\text { 일일(연간) 최대 } \\
\text { 여객처리 수 }\end{array}$} & $\begin{array}{l}\text { 1) 1일 최대 여객 처리 수: } 25 \text { 만명 } \\
\text { 2) 연간 최대 여객 처리 수: } 3,556 \text { 만 } 2,000 \text { 명 }\end{array}$ \\
\hline \multirow{2}{*}{$\begin{array}{l}\text { 공항의 } \\
\text { 장·단점 }\end{array}$} & 장점 & $\begin{array}{l}\text { - 외국인 방문객들을 위해 그 나라의 고유문화를 보여줄 수 있는 그림, 조각, 수공예 } \\
\text { 품, 자수, 사진 등의 예술작품을 공항에 전시하고 있음 } \\
\text { - 공항철도를 이용하면 시티까지 빠르게 이동할 수 있고, 버스를 이용하면 저렴하게 } \\
\text { 이동이 가능함 } \\
\text { - 시드니 공항 주변에는 여행객들을 위한 숙박시설이 많이 위치해 있음 }\end{array}$ \\
\hline & 단점 & $\begin{array}{l}\text { - 시드니 공항이 시내로부터 다소 외각에 위치하고 있어 공항 앞에는 볼거리가 부족함 } \\
\text { - 시내까지 가는 버스의 배차간격이 } 30 \text { 분 1시간 이상 소요되기 때문에 버스 이용 } \\
\quad \text { 시 기다림이 불편함 } \\
\text { - 시드니 공항은 짙은 연기와 남쪽에서 불어오는 강풍으로 인해 비행기 지연 사례가 } \\
\quad \text { 많음 }\end{array}$ \\
\hline
\end{tabular}




\begin{tabular}{|c|c|c|}
\hline \multirow{2}{*}{$\begin{array}{l}\text { 공항 } \\
\text { 주변 } \\
\text { 관광 } \\
\text { 자원 }\end{array}$} & 유명 관광지 & $\begin{array}{l}\text { - 시드니 오페라 하우스(Sydney Opera House) } \\
\text { - 팜비치(Palm Beach) } \\
\text { - 서큘러 키(Circular Quay) } \\
\text { - 시드니 하버 브리즈(Sydney Harbour Bridge) } \\
\text { - 시드니 왕립 식물원(Royal Botanic Gardens) } \\
\text { - 달링 하버(Darling Harbour) } \\
\text { - 스타디움 오스트레일리아(Stadium Australia) }\end{array}$ \\
\hline & 관광 상품 & $\begin{array}{l}\text { - 시드니 오페라 하우스 공연 관람 } \\
\text { - 시드니의 유명한 식당, 베넬롱에서 시드니 하버 감상 및 식사 } \\
\text { - 시드니 하버 브리지 정상 오르기 } \\
\text { - 페리로 맨리에서 에코 트레저스 스노클링 투어 } \\
\text { - 블루 마운팅에서 산악 자전거 체험 } \\
\text { - 코카투 아일랜드에서 야외 캠핑 }\end{array}$ \\
\hline \multicolumn{2}{|c|}{ 본 공항의 특징 } & 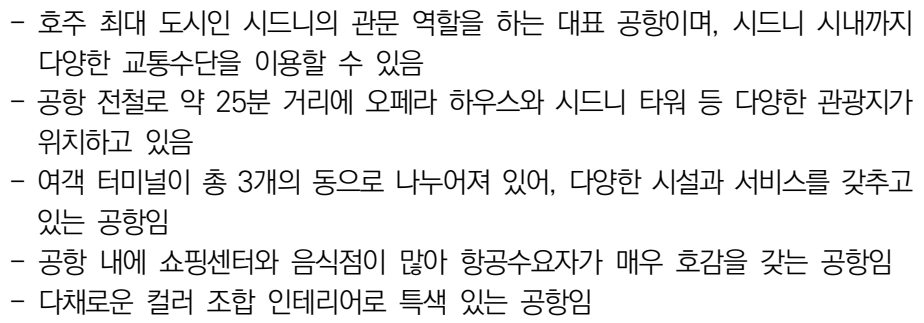 \\
\hline
\end{tabular}

\section{나. 멜버른 공항(MEL): 도심거점형, 남부지역 위치}

\begin{tabular}{|c|c|c|}
\hline \multirow{3}{*}{$\begin{array}{l}\text { 설립 } \\
\text { 연도 } \\
\text { 및 } \\
\text { 위치 }\end{array}$} & 설립연도 & 1970년 설립 \\
\hline & $\begin{array}{l}\text { 소재지 } \\
\text { (주소) }\end{array}$ & Melbourne Airport VIC 3045, Australia \\
\hline & 접근성 & $\begin{array}{l}\text { - ‘스카이 버스' 에서 운영하는 셔틀버스와 트램이 멜버른 도심까지 운행(24시간 } \\
\text { 운행 / 평상시에는 10분 간격이며 심야에는 30분 간격으로 운행됨 / 평균 30분 } \\
\text { 이면 도심으로 갈 수 있음 / 왕복 1인 호주\$35, 편도 1인 호주\$18 / 스카이버 } \\
\text { 스를 타면 시내의 서던 크로스 역까지 연결됨) } \\
\text { - 택시나 우버 등 이용가능(택시 이용 시 30 50분 정도 소요) }\end{array}$ \\
\hline \multicolumn{2}{|c|}{$\begin{array}{l}\text { 운항하고 있는 } \\
\text { 항공사 현황 }\end{array}$} & $\begin{array}{l}\text { - 1터미널 : 콴타스 항공, 콴타스 링크, 젯스타 항공 } \\
\text { - 2터미널 : 콴타스 항공, 스트레직 항공, 버진 오스트레일리아 항공, 제트스타 항 } \\
\text { 공, 아시아나 항공, 중국 국제항공 포함 } 4 \text { 개 중국 항공사, 캐세이퍼시픽, 일본 } \\
\text { 항공, 중화항공, 말레이시아 항공, 에어 아시아X, 베트남 항공, 로얄 브루나이 항 } \\
\text { 공, 에어 뉴질랜드. 이외 동남아 항공 포함한 } 14 \text { 개 항공사 등 } \\
\text { - 3터미널 : 리저널 익스프레스 항공, 버진 오스트레일리아 리저널 항공, 버진 오스 } \\
\text { 트레일리아 } \\
\text { - 4터미널 : 타이거 항공 오스트레일리아 }\end{array}$ \\
\hline \multicolumn{2}{|c|}{$\begin{array}{l}\text { 일일(연간) 최대 } \\
\text { 여객처리 수 }\end{array}$} & $\begin{array}{l}\text { 1) 1일 최대 여객 처리 수: } 30,227 \text { 명 } \\
\text { 2) 연간 최대 여객 처리 수: } 37,395,992 \text { 명(2018/2019) }\end{array}$ \\
\hline
\end{tabular}




\begin{tabular}{|c|c|c|}
\hline \multirow{2}{*}{$\begin{array}{l}\text { 공항의 } \\
\text { 장·단점 }\end{array}$} & 장점 & $\begin{array}{l}\text { - 멜버른에 접근성이 매우 좋음 } \\
\text { - 공항이 시내에서 멀지 않은 곳에 위치(스카이버스로 약 20분) } \\
\text { - 공항에서 시내로 이동할 때 24시간 연중무휴로 운영하는 스카이 버스라는 간편 } \\
\text { 한 교통수단 있음(와이파이 무료 제공) } \\
\text { - 국제선 및 국내선을 동시에 이용할 수 있음 } \\
\text { - 공항이 크지는 않지만 쾌적함 }\end{array}$ \\
\hline & 단점 & $\begin{array}{l}\text { - 멜버른 공항은 툴라마린 공항으로 흔히 불리며, 저가항공사의 국내선을 이용할 } \\
\quad \text { 때는 아발론 공항과 혼동될 수 있음 } \\
\text { - 제1터미널부터 제4터미널까지 있어 처음 방문하는 사람들은 헷갈리기 쉬움 } \\
\text { - 공항철도나 지하철 등 철도교통이 없음 } \\
\text { - 시내로 나가는 대중교통이 버스밖에 없음 }\end{array}$ \\
\hline \multirow{2}{*}{$\begin{array}{l}\text { 공항 } \\
\text { 주변 } \\
\text { 관광 } \\
\text { 자원 }\end{array}$} & 유명 관광지 & $\begin{array}{l}\text { - 퀸 빅토리아 마켓(Queen Victoria Market) } \\
\text { - 빅토리아 국립미술관(National Gallery of Victoria) } \\
\text { - 멜버른 박물관(Melbourne Museum) } \\
\text { - 멜버른 로크 아드 고지(Loch Ard Gorge): 그레이트 오션로드 } \\
\text { - 유레카 타워(Eureka Tower) } \\
\text { - 12도상(12 Apostles): 트래킹을 할 수 있는 국립공원 } \\
\text { - 패더레이션 스퀘어(Federation Square) }\end{array}$ \\
\hline & 관광 상품 & $\begin{array}{l}\text { - 멜버른 상징 트램을 타고 둘러보는 시티 투어 } \\
\text { - 호시어 레인: 미사거리로 유명한 그래피티 골목 } \\
\text { - 프린세스 브릿지 주변에서 일몰과 야경 감상 } \\
\text { - 피츠로이 가든: 멜버른 시내 공원 } \\
\text { - 호드 캠벨: 해변 } \\
\text { - 에티하드 스타디움: 다목적 경기장 } \\
\text { - 퍼핑 빌리: 증기기관차가 있는 동화마을 } \\
\text { - 로열 보타닉 가든 }\end{array}$ \\
\hline \multicolumn{2}{|c|}{ 본 공항의 특징 } & $\begin{array}{l}\text { - 호주에서 } 2 \text { 번째로 많이 이용되어 가장 바쁜 공함임 } \\
\text { - 제 } 1,3,4 \text { 터미널은 국내선 터미널, 제2터미널은 국제선 터미널로 운영되고 있음 } \\
\text { - 스마트 게이트에서 입국심사를 자동으로 빠르고 편리하게 할 수 있음 } \\
\text { - 공항에서 평균 } 30 \text { 분이면 멜버른 도심으로 갈 수 있어 접근성이 좋다는 것이 본 } \\
\text { 공항의 큰 장점임 } \\
\text { - 공항버스 시스템이 가장 잘 되어있는 공항 중 하나임 }\end{array}$ \\
\hline
\end{tabular}




\section{다. 브리즈번 공항(BNE): 지역연계형, 동부지역 위치}

\begin{tabular}{|c|c|c|}
\hline \multirow{3}{*}{$\begin{array}{l}\text { 설립 } \\
\text { 연도 } \\
\text { 및 } \\
\text { 위치 }\end{array}$} & 설립연도 & 1942년 설립 \\
\hline & $\begin{array}{l}\text { 소재지 } \\
\text { (주소) }\end{array}$ & 11 The Circuit, Brisbane Airport QLD 4008 Australia \\
\hline & 접근성 & $\begin{array}{l}\text { - 브리즈번 시티에 위치한 중앙역으로 직행하는 공항 열차가 수시로 운영됨. 시내 } \\
\text { 중앙역과 공항에 위치한 터미널 간의 소요시간은 약 } 21 \text { 분 } \\
\text { - 골드코스트 - 브리즈번 - 공항까지 직통하는 전철이 운행 중이며, 골드코스트에 } \\
\text { 서 공항까지는 } 2 \text { 시간 소요(버스가 각 터미널에서 시내 호텔까지 } 30 \text { 분 간격으로 } \\
\text { 운행되며, 기차도 } 15 \text { 분 간격으로 운행됨. 택시는 약 } 20 \text { 분 소요) }\end{array}$ \\
\hline \multicolumn{2}{|c|}{$\begin{array}{l}\text { 운항하고 있는 } \\
\text { 항공사 현황 }\end{array}$} & $\begin{array}{l}\text { - 국제선 : 대한항공, 로얄 브루나이 항공, 말레이시아 항공, 버진 오스트레일리아 } \\
\text { 항공, 버진 사모아, 싱가포르 항공, 스트레직 항공, 나우루 항공, 에미레이트 항 } \\
\text { 공, 에바 항공, 에어 뉴질랜드, 에어 뉴기니, 에어 바누아투, 에어 칼린, 피지 항 } \\
\text { 공, 에티하드 항공, 중국남방항공, 중국동방항공, 중화항공, 제트스타 항공, 캐세 } \\
\text { 이퍼시픽 항공, 콴타스 항공, 타이 항공 } \\
\text { - 국내선 : 에로펠리컨 에어 서비스, 브린다벨라 항공, 젯스타 항공, 콴타스 항공, } \\
\text { 버진 오스트레일리아 리저널 항공, 스트레직 항공, 타이거 항공 오스트레일리아, } \\
\text { 버진 오스트레일리아 }\end{array}$ \\
\hline \multicolumn{2}{|c|}{$\begin{array}{l}\text { 일일(연간) 최대 } \\
\text { 여객처리 수 }\end{array}$} & $\begin{array}{l}\text { 1) 1일 평균 여객 처리수 : } 53,151 \text { 명 } \\
\text { 2) 연간 최대 여객 처리 수: } 19,400,000 \text { 명(2010년 기준) }\end{array}$ \\
\hline \multirow[t]{2}{*}{$\begin{array}{l}\text { 공항의 } \\
\text { 장·단점 }\end{array}$} & 장점 & $\begin{array}{l}\text { - 국제여객 항공 노선망이 잘 갖추어져 있음(대한항공도 취항) } \\
\text { - 국제선 및 국내선을 동시에 이용할 수 있음 } \\
\text { - 국내선 터미널과 국제선 터미널간 무료 셔틀버스(T-Bus) 운행 } \\
\text { - 브리즈번 시티에 위치한 중앙역(central station)으로 직행하는 공항열차 Airtrain } \\
\text { 수시 운영(소요시간 약 21분) } \\
\text { - 버스가 각 터미널에서 시내 주요 호텔까지 운행하며 30분 소요, 기차는 15분 간격 } \\
\text { - 으로 운행 } \\
\text { - 호주 각 지역에서 공항픽업 서비스를 운행하는 Con-X-Ion 버스가 있음 }\end{array}$ \\
\hline & 단점 & $\begin{array}{l}\text { - 멜버른 공항, 시드니 공항 등 다른 공항의 셔틀버스나 공항철도에 비하면 가격이 } \\
\text { 비싼 편임 } \\
\text { - 공항으로 가는 버스가 있지만 철도에 비해 배차간격이 길고 제한된 노선에만 운 } \\
\text { 행되고 있음 }\end{array}$ \\
\hline \multirow{2}{*}{$\begin{array}{l}\text { 공항 } \\
\text { 주변 } \\
\text { 관광 } \\
\text { 자원 }\end{array}$} & 유명 관광지 & $\begin{array}{l}\text { - 사우스뱅크 파크랜드(South Bank Parklands) } \\
\text { - 론 파인(Lone Pine) 코알라 보호구역 } \\
\text { - 옛 피트리 마을(Old Petrie Town) } \\
\text { - 스토리 브릿지(Story Bridge) }\end{array}$ \\
\hline & 관광 상품 & $\begin{array}{l}\text { - 잇 스트릿 마켓(Eat Street): 초대형 실외 푸드코트 컨테이너, 라이브 공연 } \\
\text { - 보타닉 가든: 도심 속 휴식처 같은 공원 } \\
\text { - 퀸 스트리트 몰: 브리즈번에서 가장 번화한 거리, 대형 쇼핑몰, 버스킹 관람 } \\
\text { - 스트리트 비치 해수욕 : 도심 속에 위치한 인공해변 }\end{array}$ \\
\hline \multicolumn{2}{|c|}{ 본 공항의 특징 } & $\begin{array}{l}\text { - 국제선 터미널은 에미레이트 항공의 } 1 \text { 등석 라운지를 운영 중이며 향후 콴타스 } \\
\text { 항공, 싱가포르 항공, 에어 뉴질랜드의 라운지도 갖출 예정으로 더 많은 사람들 } \\
\text { 이 공항에서 보다 편안하게 대기할 수 있음 } \\
\text { - 아담한 규모의 국제공항이지만 면세점, 환전소, 여행정보센터 등 편의시설이 잘 } \\
\text { 갖추어져 있음 } \\
\text { - 청사 2,3,4층에는 환승객을 위한 무료 샤워시설이 잘 갖추어져 있음(샤워용품 무 } \\
\text { 료 제공) } \\
\text { - 대부분의 국제선공항 면세점은 명품관이지만 브리즈번 국제공항 면세점은 특산품 } \\
\text { 아울렛이라 기념품이 시내보다 더 저렴함 } \\
\text { - 버스가 각 터미널에서 시내 주요 호텔까지 } 30 \text { 분 간격으로 운행되고 있음 }\end{array}$ \\
\hline
\end{tabular}




\section{라. 퍼스 공항(PHE): 지역연계형, 서부지역 위치}

\begin{tabular}{|c|c|c|}
\hline \multirow{3}{*}{$\begin{array}{l}\text { 설립 } \\
\text { 연도 } \\
\text { 및 } \\
\text { 위치 }\end{array}$} & 설립연도 & 1938년 설립 / 1952년 국제선 영업 \\
\hline & $\begin{array}{l}\text { 소재지 } \\
\text { (주소) }\end{array}$ & Perth Airport WA 6105 Australia \\
\hline & 접근성 & 도심에서 택시나 버스 이용 시 공항까지 35분 \\
\hline \multicolumn{2}{|c|}{$\begin{array}{l}\text { 운항하고 있는 } \\
\text { 항공사 현황 }\end{array}$} & $\begin{array}{l}\text { - 국제선(1,3터미널) : 인도네시아(가루다 인도네시아 항공, 인도네시아 에어아시 } \\
\text { 아), 브루나이(로열 브루나이 항공), 남아프리카(남아프리카 항공), 말레이시아(말 } \\
\text { 레이시아 항공, 에어아시아 엑스), 중국(중국남방항공), 일본(전일본공수), 싱가포 } \\
\text { 르(싱가포르 항공, 스쿠트 항공), 두바이(에미레이트 항공), 아랍에미레이트(에티 } \\
\text { 하드 항공), 뉴질랜드(에어 뉴질랜드), 모리셔스(에어 모리셔스), 호주(콴타스 항 } \\
\text { 공, 제트트타 항공, 버진 오스트레일리아), 홍콩(캐세이퍼시픽 항공), 태국(타이항 } \\
\text { 공), 카타르(카타르 항공) } \\
\text { - 국내선(1,2,3,4터미널) : 버진 오스트레일리아, 콴타스 항공, 코밤 항공, 제트스타 등 }\end{array}$ \\
\hline \multicolumn{2}{|c|}{$\begin{array}{l}\text { 일일(연간) 최대 } \\
\text { 여객처리 수 }\end{array}$} & $\begin{array}{l}\text { 1) 1일 최대 여객 처리 수: 453,602명(2020년 1월 국제선 기준) } \\
\text { 2) 연간 최대 여객 처리 수: } 11,241,563 \text { 명(2019년 7월 2020년 4월) }\end{array}$ \\
\hline \multirow{2}{*}{$\begin{array}{l}\text { 공항의 } \\
\text { 장·단점 }\end{array}$} & 장점 & $\begin{array}{l}\text { - 2016년에 국제선 터미널의 리노베이션이 완료되어 매우 깔끔하고 현대적인 시설 } \\
\text { 을 갖추고 있음 } \\
\text { - 1터미널부터 4터미널까지 터미널마다 도심부까지 이동할 수 있는 버스 정류장이 } \\
\text { 위치하고 있어 교통이 매우 편리함 } \\
\text { - 국제선터미널이 } 24 \text { 시간 영업하며 새벽까지 운영하는 커피숍이 있음 }\end{array}$ \\
\hline & 단점 & $\begin{array}{l}\text { - 이용객이 많을 때는 직원 부족으로 인하여 체크인 카운터 혼잡 } \\
-1,2 \text { 터미널에서 } 3,4 \text { 터미널로 이동 시 약 } 1 \text { 시간이 소요되어 국제선에서 국내선 환 } \\
\text { 승 시 불편함 초래 } \\
\text { - 공항 고객서비스를 평일에만 운영하여 주말이용객 불만 고조 }\end{array}$ \\
\hline \multirow{2}{*}{$\begin{array}{l}\text { 공항 } \\
\text { 주변 } \\
\text { 관광 } \\
\text { 자원 }\end{array}$} & 유명 관광지 & $\begin{array}{l}\text { - 킹스파크(Kings Park) } \\
\text { - 런던 코트(London Court) } \\
\text { - 서호주 미술관 } \\
\text { - 스완벨타워(Swan Bells) } \\
\text { - 엘리자베스 퀴(Elizabeth Quay) }\end{array}$ \\
\hline & 관광 상품 & $\begin{array}{l}\text { - 퍼스 로트네스트 섬에서만 볼 수 있는 쿼카와 사진 촬영 } \\
\text { - 프리맨틀 마켓의 예술가 거리공연 관람 } \\
\text { - 코텐슬로 비치 해수욕과 해상 레저스포츠 체험 } \\
\text { - 무료 관광버스 CAT로 떠나는 퍼스 시티투어 }\end{array}$ \\
\hline \multicolumn{2}{|c|}{ 본 공항의 특징 } & $\begin{array}{l}\text { - 2019년 호주 경쟁 및 소비자 위원회 모니터링 보고서에서 항공사가 선정한 호주 } \\
\text { 최고의 주요 공항으로 평가받았으며, } 2 \text { 년 연속 전반적인 품질(항공사와 승객)면에 } \\
\text { 서 최우수 주요 공항으로 평가 받을 만큼 우수한 공항임 } \\
\text { - 2020년 내에 공항까지의 지하철 노선이 첫 운행될 예정이며, 주차장 시설을 포함 } \\
\text { 한 다양한 시설들이 2025년까지 리노베이션·확장 공사가 예정되어 있어 발전 가 } \\
\text { 능성이 높은 공항임 } \\
\text { - 지리상 호주의 가장 서쪽에 위치하고 있기에 중동이나 멀리는 유럽까지의 항공 } \\
\text { 노선 개척이 가능함 } \\
\text { - 퍼스 공항은 수익성만 따지지 않고 지역 내 학교와 스포츠 단체, 지역 사회와 함께 } \\
\text { 지속적인 협력관계를 형성하고 있음 }\end{array}$ \\
\hline
\end{tabular}




\section{마. 애들래이드 공항(ADL): 지역연계형, 남부지역 위치}

\begin{tabular}{|c|c|c|}
\hline \multirow{3}{*}{$\begin{array}{l}\text { 설립 } \\
\text { 연도 } \\
\text { 및 } \\
\text { 위치 }\end{array}$} & 설립연도 & 1955년 설립 \\
\hline & $\begin{array}{l}\text { 소재지 } \\
\text { (주소) }\end{array}$ & 1 James Schofield Dr, Adelaide Airport SA 5950 Australia \\
\hline & 접근성 & 도심에서 서쪽으로 약 $6 \mathrm{~km}$ (버스, 택시, 우버 등) \\
\hline \multicolumn{2}{|c|}{$\begin{array}{l}\text { 운항하고 있는 } \\
\text { 항공사 현황 }\end{array}$} & $\begin{array}{l}\text { - 국제선 : 말레이시아(말레이시아 항공), 중국(중국남방항공), 싱가포르(싱가포르 } \\
\text { 항공), 뉴질랜드(에어 뉴질랜드), 홍콩(케세이퍼시픽 항공), 오스트레일리아(젯스 } \\
\text { 타 항공), 아랍에미레이트(에미레이트 항공), 피지(피지항공), 카타르(카타르 항 } \\
\text { 공)까지 총 } 9 \text { 개 항공사 운항 } \\
\text { - 국내선 : 리저널 익스프레스 항공, 버진 오스트레일리아, 샤프 항공, 알린스 항공, } \\
\text { 젯스타 항공, 코밤 항공 서비스 오스트레일리아, 콴타스 링크(코밤 운영), 콴타스 } \\
\text { 항공, 콴타스 항공(콴타스-알린스 에어라인 운영), 콴타스 항공(콴타스 링크 운 } \\
\text { 영)까지 총 } 10 \text { 개 항공사 운항 }\end{array}$ \\
\hline \multicolumn{2}{|c|}{$\begin{array}{l}\text { 일일(연간) 최대 } \\
\text { 여객처리 수 }\end{array}$} & $\begin{array}{l}\text { 1) 1일 최대 여객 처리 수: } 22,208 \text { 명(2019년 5월 기준) } \\
\text { 2) 연간 최대 여객 처리 수: } 8,527,000 \text { 명 }\end{array}$ \\
\hline \multirow{2}{*}{$\begin{array}{l}\text { 공항의 } \\
\text { 장·단점 }\end{array}$} & 장점 & $\begin{array}{l}\text { - 규모가 작은 도시이지만 국제선까지 운항하고 있음 } \\
\text { - 셀프 체크인 및 수화물 시스템으로 빠른 출국 시스템 } \\
\text { - 영업시간이 아닐 때에도 랜드사이드에 24시간 머물 수 있으며, 보안이 뛰어나 } \\
\text { 노숙하기 좋은 세계 공항 } 29 \text { 위에 선정되었음 }\end{array}$ \\
\hline & 단점 & $\begin{array}{l}\text { - 수화물이 늦게 나오며 국제선 이용객에 대한 세관 심사가 까다로워 입국 후에 } \\
\text { 공항 밖으로 나가기까지 많은 시간이 소요됨 } \\
\text { - 면세점이 작고 부실하다는 평이 많음 } \\
\text { - 공항에서 택시·버스 승강장까지 멀리 떨어져 있음 }\end{array}$ \\
\hline \multirow{2}{*}{$\begin{array}{l}\text { 공항 } \\
\text { 주변 } \\
\text { 관광 } \\
\text { 자원 }\end{array}$} & 유명 관광지 & $\begin{array}{l}\text { - 노스 테라스(North Terrace) } \\
\text { - 남호주 박물관(South Australian Museum) } \\
\text { - 남호주 아트 갤러리(Art Gallery of South Australia) } \\
\text { - 호주 내셔널 와인 센터(National Wine Centre of Australia) }\end{array}$ \\
\hline & 관광 상품 & $\begin{array}{l}\text { - 빅토리아 스퀘어(Victoria Square) 산책 } \\
\text { - 애들레이드 보타닉 가든(Adelaide Botanic Garden) 온실 방문 } \\
\text { - 토렌스강(Torrens River) 자전거 산책 } \\
\text { - 런드 몰(Rundle Mall)의 마스코트인 돼지 4형제 찾기 } \\
\text { - 센트럴 마켓 투어(Adelaide Central Market Tour) }\end{array}$ \\
\hline \multicolumn{2}{|c|}{ 본 공항의 특징 } & $\begin{array}{l}\text { - 9개 국제 지점과 전 세계 } 300 \text { 개 이상 도시들과 직항편으로 연결되어 있음 } \\
\text { - 호주 내에 있는 공항 중 가장 모던한 공항임 } \\
\text { - 애들레이드 공항은 두바이에서 세계 공항 중 } 2 \text { 번째로 좋은 국제공항 상을 받은 } \\
\text { 적이 있는 만큼 쾌적한 공항임 } \\
\text { - 공항 바로 옆에 글레넬그 해변이 위치하고 있어서 환승 시 여유시간이 있다면 } \\
\quad \text { 남호주의 바다 구경 가능 } \\
\text { - 공항의 규모와 시설 수가 이용객 수에 알맞게 적절한 공항임 } \\
\text { - 자동화된 체크인과 수회물 시스템은 외국인에게 어렵다는 평이 많으며 문의 시 } \\
\text { 공항 직원의 인종차별문제가 주의를 요함 }\end{array}$ \\
\hline
\end{tabular}




\section{바. 골드코스트 공항(OOL): 지역연계형, 동부지역 위치}

\begin{tabular}{|c|c|c|}
\hline \multirow{3}{*}{$\begin{array}{l}\text { 설립 } \\
\text { 연도 } \\
\text { 및 } \\
\text { 위치 }\end{array}$} & 설립연도 & 1939년 설립 \\
\hline & $\begin{array}{l}\text { 소재지 } \\
\text { (주소) }\end{array}$ & Eastern Avenue, Bilinga QLD 4225 Australia \\
\hline & 접근성 & $\begin{array}{l}\text { - 로비나 역에서 공항까지 } 1 \text { 시간 } 30 \text { 분정도가 소요됨 (버스, 트램을 주로 이용함. } \\
\text { ‘그레이 하운드’라는 장거리 버스도 많이 이용하며, 운행간격은 10 30분) } \\
\text { - 스카이 버스는 노선 } 2 \text { 개가 운행되며, 수르프 사이드 버스라인에 의해 7일 동안 } \\
\text { 운행됨 }\end{array}$ \\
\hline \multicolumn{2}{|c|}{$\begin{array}{l}\text { 운항하고 있는 } \\
\text { 항공사 현황 }\end{array}$} & $\begin{array}{l}\text { - 국제선 : 젯스타 항공, 버진 오스트레일리아, 에어 아시아, 에어 뉴질랜드, 스쿠트 등 } \\
\text { - 국내선 : 콴타스 항공, 에어 노스, 타이거 항공 오스트레일리아, 버진 오스트레일 } \\
\text { 리아, 젯스타 항공, 시에어 퍼시픽 등 }\end{array}$ \\
\hline \multicolumn{2}{|c|}{$\begin{array}{l}\text { 일일(연간) 최대 } \\
\text { 여객처리 수 }\end{array}$} & $\begin{array}{l}\text { 1) } 1 \text { 일 평균 여객 처리 수: } 14,910 \text { 명(2010년 기준) } \\
\text { 2) 연간 최대 여객 처리 수: } 5,441,890 \text { 명(2010년 기준) }\end{array}$ \\
\hline \multirow{2}{*}{$\begin{array}{l}\text { 공항의 } \\
\text { 장·단점 }\end{array}$} & 장점 & $\begin{array}{l}\text { - 국제선과 국내선을 동시에 이용할 수 있음 } \\
\text { - T1과 T2는 가까이에 위치하고 걸어서 다니면 1 2분 정도로, 공항이 작아서 복잡 } \\
\text { 하지 않은 장점이 있음 } \\
\text { - 공항에서 버스를 이용하여 } 30 \text { 분 정도 가면 비치, 메인로드, 쇼핑몰(마트)이 있어 } \\
\text { 가깝게 이용할 수 있음(하지만 도심과 많이 가까운 것은 아님) }\end{array}$ \\
\hline & 단점 & $\begin{array}{l}\text { - 공항이 매우 작아 유명한 것이나 구경거리가 없음(실제 제주공항보다 작음) } \\
\text { - 공항이 작아 공항 안이나 주변에 식당가가 부족함 } \\
\text { - 도심에 가려면 한 시간 정도 대중교통을 이용하여야 함 } \\
\text { - 주변 YHA이나 Kirra beach(가까운 해변)으로 갈 때 짧은 거리지만 걸어 다닐 } \\
\text { 정도의 도로가 없어 조심히 이동해야 함 }\end{array}$ \\
\hline \multirow{2}{*}{$\begin{array}{l}\text { 공항 } \\
\text { 주변 } \\
\text { 관광 } \\
\text { 자원 }\end{array}$} & 유명 관광지 & $\begin{array}{l}\text { - 서퍼스 파라다이스(Surfers Paradise) } \\
\text { - Q1 타워와 스카이 포인트(Q1 Tower \& Skypoint) } \\
\text { - 씨월드(Sea World) } \\
\text { - 열대과일농장 } \\
\text { - 파라다이스 컨츄리(Paradaise Country Farm) }\end{array}$ \\
\hline & 관광 상품 & $\begin{array}{l}\text { - 서퍼스 파라다이스에서 서핑 강습 } \\
\text { - 하버타운 쇼핑 } \\
\text { - 골드코스트 헬기투어 } \\
\text { - 파라다이스 나이트 마켓 구경과 먹거리 체험 } \\
\text { - 서퍼스 파라다이스 해변과 카비 애비뉴 근처 버스킹 공연 관람 }\end{array}$ \\
\hline \multicolumn{2}{|c|}{ 본 공항의 특징 } & $\begin{array}{l}\text { - 골드코스트에 방문하는 관광객이 매해 늘어남에 따라, 공항 이용률 또한 호주 내 } \\
\text { 에서 성장이 가장 빠른 곳으로 주목받는 공항 } \\
\text { - 같은 퀸즐랜드주에 위치한 브리즈번 공항에 비해 상대적으로 노선망이 부실 } \\
\text { - 국내선 위주의 공항이기 때문에 규모가 작지만 복잡하지 않음 } \\
\text { - 골드코스트 공항을 이용하는 여객이라면 '서퍼스 파라다이스 호텔'은 꼭 이용해 } \\
\text { 보라고 할 만큼 시그니처 호텔이 있음 } \\
\text { - 공항에서 버스를 직접 예약하면 오가는 버스를 한 번에 예약할 수 있으며, 장소까 } \\
\text { 지 지정이 가능하여 굉장히 편리하게 이용 가능 } \\
\text { - 버스 노선 2개로 교통이 좋은 편은 아니지만 시내로 가는 버스가 수시로 운영되 } \\
\quad \text { 어 이동시 불편함이 적음 }\end{array}$ \\
\hline
\end{tabular}




\section{사. 케언스 공항(CNS): 지역연계형, 동부지역 위치}

\begin{tabular}{|c|c|c|}
\hline \multirow{3}{*}{$\begin{array}{l}\text { 설립 } \\
\text { 연도 } \\
\text { 및 } \\
\text { 위치 }\end{array}$} & 설립연도 & 1934년 설립 \\
\hline & $\begin{array}{l}\text { 소재지 } \\
\text { (주소) }\end{array}$ & Airport Ave, Cairns City QLD 4870 AUSTRALIA \\
\hline & 접근성 & $\begin{array}{l}\text { 케언스 시내 중심에서 북쪽으로 약 } 7 \mathrm{~km} \\
\text { 교통수단 : 택시, 셔틀버스, 정규 버스노선 이용 가능 }\end{array}$ \\
\hline \multicolumn{2}{|c|}{$\begin{array}{l}\text { 운항하고 있는 } \\
\text { 항공사 현황 }\end{array}$} & $\begin{array}{l}\text { - 국내선 : 8개 노선 } \\
\text { - 국제선 : 호주(5), 한국(1), 홍콩(1), 인도네시아(1), 미국(1), 파퓨아 뉴기니(3), } \\
\text { 뉴질랜드(2) }\end{array}$ \\
\hline \multicolumn{2}{|c|}{$\begin{array}{c}\text { 일일(연간) 최대 } \\
\text { 여객처리 수 }\end{array}$} & $\begin{array}{l}\text { 1) 1일 최대 여객 처리 수: } 3 \text { 만 명 } \\
\text { 2) 연간 최대 여객 처리 수: } 355 \text { 만 명 }\end{array}$ \\
\hline \multirow[t]{2}{*}{$\begin{array}{l}\text { 공항의 } \\
\text { 장·단점 }\end{array}$} & 장점 & $\begin{array}{l}\text { - 비교적 도심과의 접근성이 좋음 } \\
\text { - 케언스 공항은 지역 관광과 항공 산업에 이익이 되는 다양한 조직, 행사를 지원하 } \\
\text { 고 있음 } \\
\text { - 증가하는 승객 교통량을 수용하기 위해 국내선 터미널을 업그레이드하고 있으며, } \\
\quad \text { 세계적 수준의 공항 경험을 제공할 계획임 } \\
\text { - 케언스는 원시 자연이 그대로 살아있는 도시로, 공항 주변도 한적하고 조용함 }\end{array}$ \\
\hline & 단점 & $\begin{array}{l}\text { - 공항 주변에 위치한 숙소 건물들이 대체로 낡은 편임 } \\
\text { - 인터넷 조사 결과, 케언스 공항 내에 배치된 음식점들의 전체적인 평가가 낮게 } \\
\text { 나타남 }\end{array}$ \\
\hline \multirow{2}{*}{$\begin{array}{l}\text { 공항 } \\
\text { 주변 } \\
\text { 관광 } \\
\text { 자원 }\end{array}$} & 유명 관광지 & $\begin{array}{l}\text { - 스카이레일 레인포레스트 케이블웨이(Skyrail Rainforest Cableway) } \\
\text { - 쿠란다 관광열차(Kuranda Scenic Railway) } \\
\text { - 팜 코브(Palm Cove) } \\
\text { - 레인포레스테이션 자연공원(Rainforestation Nature Park) } \\
\text { - 피츠로이 섬(Fitzroy Island) } \\
\text { - 배런 폭포(Barron Falls) } \\
\text { - 오스트레일리안 버터플라이 보호구역(The Australian Butterfly Sanctuary) }\end{array}$ \\
\hline & 관광 상품 & $\begin{array}{l}\text { - 러스티 마켓 전통 재래시장에서 쇼핑 } \\
\text { - 오션스피릿 크루즈에서 스쿠버 다이빙 체험 } \\
\text { - 탱크스 아트센터 음악회 관람 } \\
\text { - 레인포레스테이션 원주민 전통 체험 } \\
\text { - 케언즈 나이트 동물원 캥거루와 코알라 등 관람 } \\
\text { - 호주 관광청에서 제공되는 케언즈 열기구 탑승 }\end{array}$ \\
\hline \multicolumn{2}{|c|}{ 본 공항의 특징 } & $\begin{array}{l}\text { - 케언스 공항은 호주의 주요 지방공항들 중 하나로 국내외의 다양한 지역들로 연 } \\
\text { 결되는 항공노선을 제공하고 있음 } \\
\text { - 케언스 공항은 도쿄, 오사카, 싱가포르, 선전, 발리에서 출발하는 직항 편이 있어 } \\
\text { 호주에서 7번째로 승객들이 많음 } \\
\text { - 호주공항협회 국가 공항 산업상을 타며 공항의 위상을 높이고 있음 } \\
\text { - 장애인을 위한 시설이 있어 소수자의 배려가 돋보임 }\end{array}$ \\
\hline
\end{tabular}




\section{집필내역}

연구책임

이원희 한국문화관광연구원 연구위원 : 제1장, 제2장, 제3장, 제4장, 제 5 장, 제 6 장

공동연구

박진서 한국교통연구원 연구위원 : 제2장, 제 5 장, 제6장

연구자문

이휘영 인하공업전문대학 교수

조사기관

(주)리서치랩

지방공항을 활용한 지역관광 활성화 방안

발행인 김대관

발행처 한국문화관광연구원

서울시 강서구 금낭화로 154

전화 02-2669-9800 팩스 02-2669-9880

http://www.kcti.re.kr

인쇄일 2020년 10월 19일

발행일 2020년 10월 19일

인쇄인 (사)한국장애인이워크협회 일자리사업장

I S B N 978-89-6035-824-993300

DOI https://doi.org/10.16937/kcti.rep.2020.e15 


\section{A Research on Inbound Tourism Activation Using Regional Airports}

\section{口㫦口

